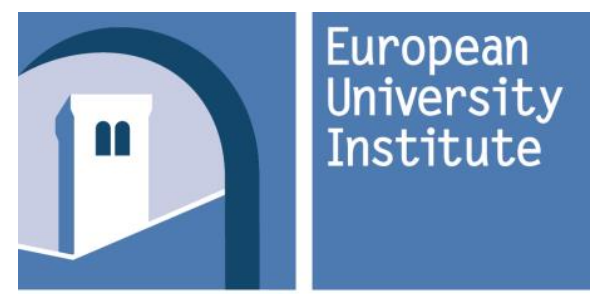

DEPARTMENT OF LAW

\title{
Dispute Resolution in Transnational Securities Transactions
}

Tiago Andreotti e Silva

Thesis submitted for assessment with a view to obtaining the degree of Doctor of Laws of the European University Institute

Florence, 16 December 2014 



\section{European University Institute \\ Department of Law}

Dispute Resolution in Transnational Securities Transactions

Tiago Andreotti e Silva

Thesis submitted for assessment with a view to obtaining

the degree of Doctor of Laws of the European University Institute

\section{Examining Board}

$\mathrm{PhD}$ Dennis Patterson, European University Institute (EUI)

PhD David Ramos Muñoz, Universidad Carlos III de Madrid (External supervisor)

PhD Marco Lamandini, Università Di Bologna

PhD Hans-W. Micklitz, European University Institute

(C) Tiago Andreotti, 2014

No part of this thesis may be copied, reproduced or transmitted without prior permission of the author 



\begin{abstract}
This PhD thesis explores how the legal infrastructure for dispute resolution in transnational securities transactions can be improved, considering the regulatory and legal limits of the financial sector in each jurisdiction under study (US, Europe and Brazil).

The two main objectives of the work are to a) identify the problems that currently exist for a dispute resolution mechanism in the securities area that can be used transnationally and b) propose solutions that can create a safe legal environment that can be used by the investor in case regulatory rules or the terms of the transaction are breached.

The work is justified by the fact that financial markets are legal constructions, making legal certainty and the mechanisms available to enforce the terms of a transaction and apply regulatory rules, especially to the investor who is part of the transaction, essential for the own existence of financial markets. Therefore, the existence of transnational financial markets also depends on the existence of a transnational legal infrastructure, at least broad enough to protect the interest of investors.

The argument developed through the work is that the creation of a transnational legal infrastructure depends on the type of dispute that is considered, since not only each type of dispute has its own peculiarities, but the national dispute resolution systems are also built based on the type of dispute that will be submitted to it. To create transnational dispute resolution systems for securities transactions, I propose the use of collective mechanisms of dispute resolution based on the initiative of private parties, the use of arbitration and the establishment of cooperation networks between national alternative dispute resolution mechanisms used to solve financial disputes.
\end{abstract}

Keywords: transnational dispute resolution, securities regulation, arbitration, collective redress, class action. 

TABLE OF CASES III

TABLE OF LEGISLATION, TREATIES AND OTHER MATERIALS. XIII

PART I - INTRODUCTION 1

CHAPTER I - THE RESEARCH PROBLEM, QUESTIONS AND LIMITATIONS OF THE STUDY 3

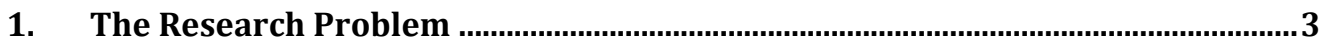

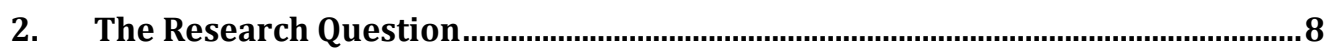

3. Thesis and Outline of the Argument................................................................ 11

4. Scope and Limitations of the Study .................................................................. 12

CHAPTER II - STATES, LAW AND DISPUTE RESOLUTION .................................... 15

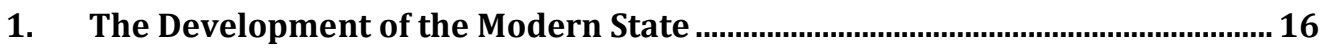

2. The Modern State, the Rule of Law and the Judiciary ….....................................21

3. The Economic Function of Law on Private Matters and Dispute Resolution . 23
A. Basic Structure: Property and Contract Rights
B. Imperfect Markets and Regulatory Law...
C. The Role of Dispute Resolution Mechanisms

4. Concluding Remarks 29

PART II - SECURITIES REGULATION.

1. The Financial Crash of $\mathbf{1 9 2 9}$ and the Creation of the Securities Regulation Framework in the United States. 


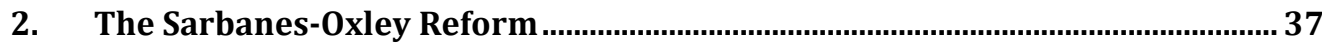

3. The 2008 Crisis and its Consequences for Securities Regulation ...................... 39

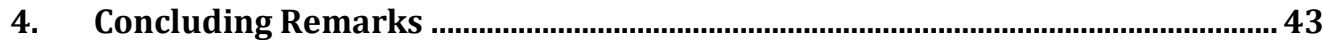

CHAPTER IV - SECURITIES REGULATION THEORY AND THE IMPORTANCE OF PRIVATE ENFORCEMENT . 45

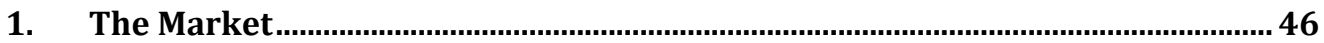

2. The Functioning of Capital Markets...................................................................... 47
A. The Mechanics of Price Accuracy
B. Consequences of Price Inaccuracy.

3. The Theoretical Justification for Securities Regulation 56
A. The Argument against a Mandatory Disclosure System 56
B. The Argument for a Mandatory Disclosure System 58

4. The Empirical Evidence for Securities Regulation 60

5. Securities Regulation in the EU 61

6. Public Law and Private Law in Securities Disputes 63

7. Institutional Aspects of Securities Regulation: The Importance of Private Enforcement 64

A. The Regulatory Regime - Institutional Aspects

B. The mix of regulatory mechanisms in securities regulation

C. The Importance of Private Enforcement in Securities Regulation 68

8. Concluding Remarks 73

1. Transacting Securities and Disputes 76

A. Issuing Securities .76 


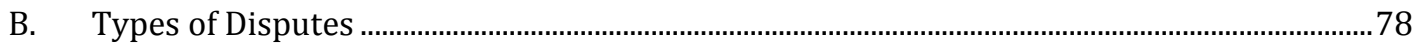

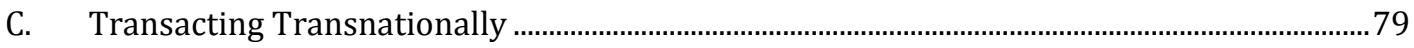

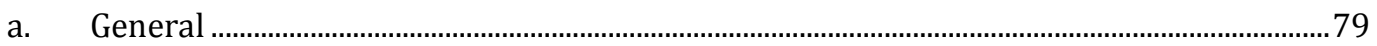

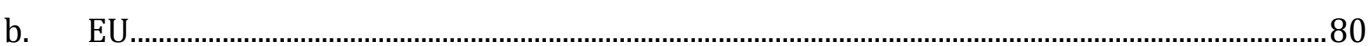

2. Legal Framework for Securities Liability - Issuers .......................................... 81

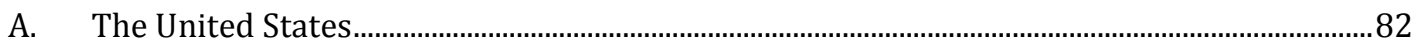

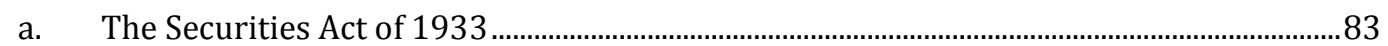

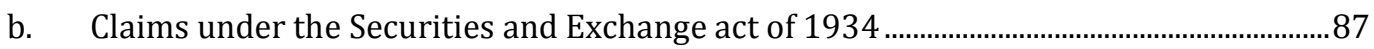

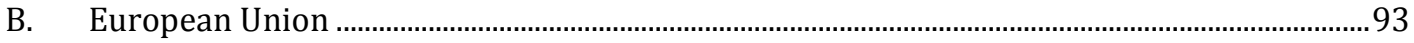

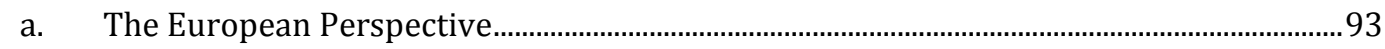

b. Implementation in Domestic Systems: the Case of Spain ....................................................95

c. Implementation in Domestic Systems: Other Jurisdictions ..............................................97

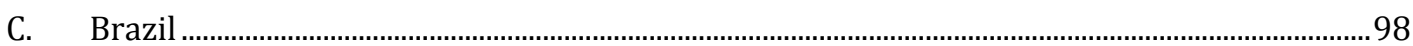

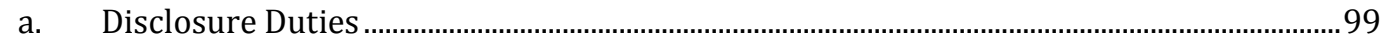

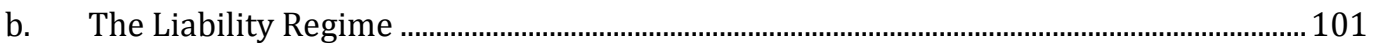

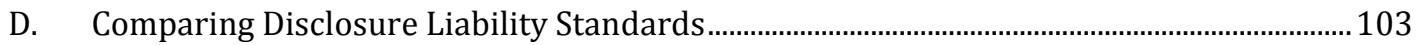

3. Legal Framework for Securities Liability - Financial Intermediaries ............106

4. Legal Framework for Securities Liability - Informational Intermediaries ..113

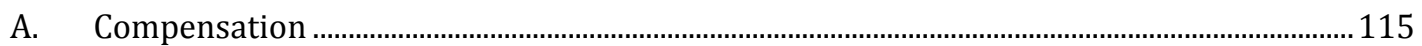

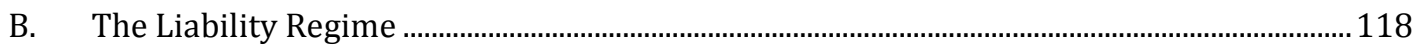

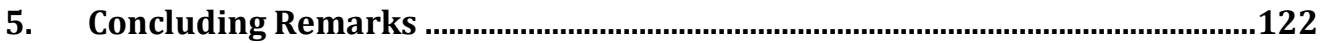

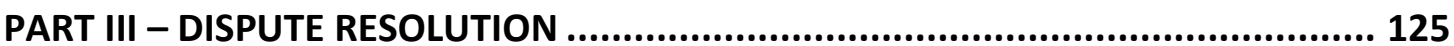

CHAPTER VI - INSTITUTIONAL ASPECTS OF DISPUTE RESOLUTION..................... 127

1. Legal Aspects of the Institutional Framework................................................128 
A. The Legal Basis of the Dispute Resolution System

a. Pure Jurisdictional Basis.

b. Consent Jurisdictional Basis: Arbitration.

c. Considerations on the Legal Basis of a Dispute Resolution System

B. The Decision-maker's Independence and Accountability........

C. The Reasoning and Publicity of Decisions.

2. Economic Aspects of the Institutional Framework.

A. Costs of Maintaining a Dispute Resolution System …........................................................... 145

B. Costs of Engaging in a Dispute Resolution Procedure ......................................................... 146
a. Costs of Access
b. Costs of Evidence and Representation

\section{Implications of the Institutional Framework for a Dispute Resolution System 149}

\section{CHAPTER VII - ALTERNATIVE MODELS OF DISPUTE RESOLUTION SYSTEMS}

1. National Models

A. Small Claims Court Model .......................................................................................................... 153

B. The Financial Ombudsman Service Model …........................................................................... 156

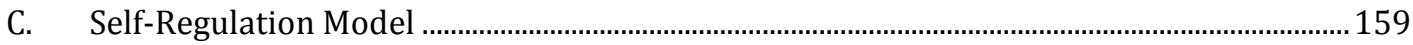

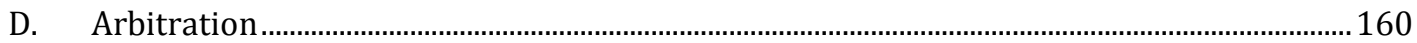

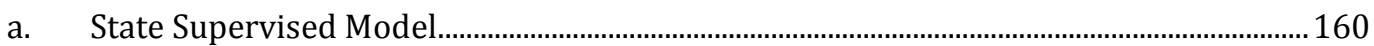

b. Private Arbitration Model.......................................................................................................... 163

2. International Models 166

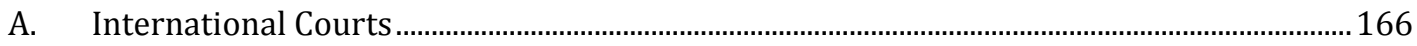

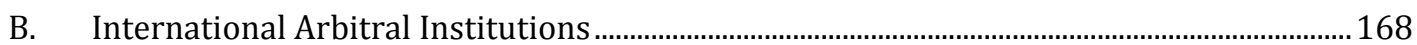

C. The European Cross-Border Mechanism for Financial Disputes: a network of dispute resolution bodies 


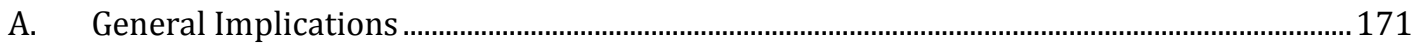

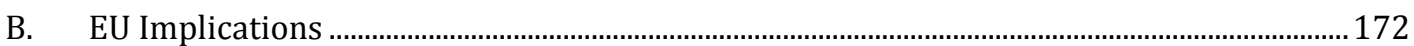

CHAPTER VIII - AGGREGATE LITIGATION DESIGN......................................... 175

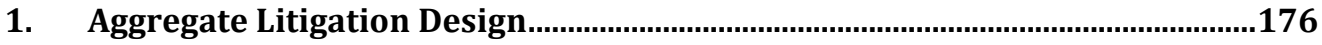

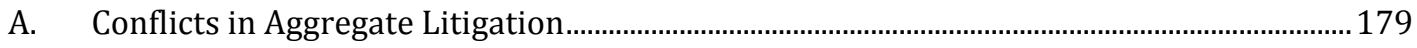

a. Conflicts between Plaintiffs and Lawyer ............................................................................. 179

b. Conflicts between Group Members ….............................................................................. 181

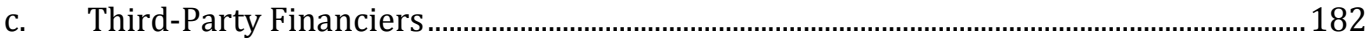

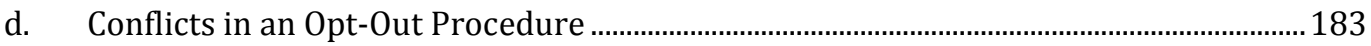

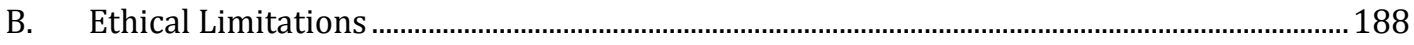

C. Preclusion Principles and Limits on Choosing an Opt-in or Opt-out Mechanism.............. 189

a. The Operation of Preclusion - general aspects .................................................................. 190

b. Preclusion and Non-Mutual Parties: possibility for the opt-out procedure.................... 197

c. Preclusion in arbitration: what law will govern its operation? .......................................... 204

D. Final Considerations on Aggregate Litigation Design ................................................................ 206

2. Aggregate Dispute Resolution and Securities Disputes ....................................207

CHAPTER IX - AGGREGATE LITIGATION MODELS ............................................ 211

1. The American Class Action

A. A Brief History of the Class Action

B. Types of Class Actions and its Prerequisites

C. Class Certification

D. Class Action and Securities Litigation

2. Representative Actions: Brazil and Spain 
A. Historical Development of Class Arbitration ............................................................................ 233

B. Class Action Waivers ..................................................................................................................... 236

C. The Types of Class Arbitration ................................................................................................ 237

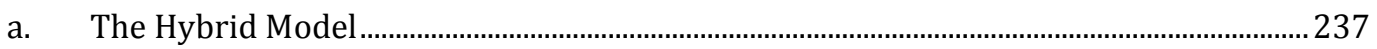

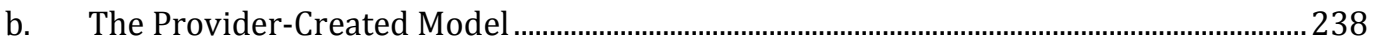

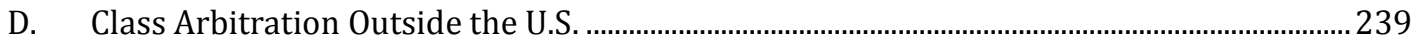

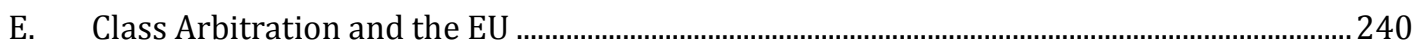

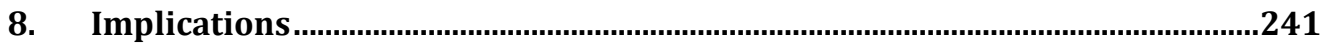

CHAPTER X - TRANSNATIONAL ASPECTS OF DISPUTE RESOLUTION ................... 243

1. Jurisdiction and Enforcement ..............................................................................244

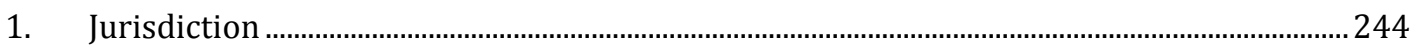

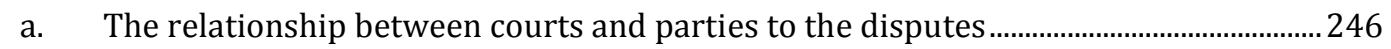

b. The relationship between the forum court and other courts ...........................................249

2. Recognition and Enforcement of Foreign Judgments ..............................................................225

a. Integrated Recognition and Enforcement Systems: the EU Example..............................258

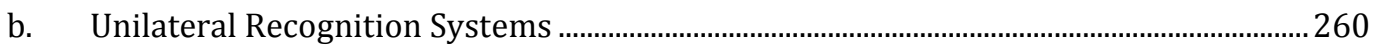

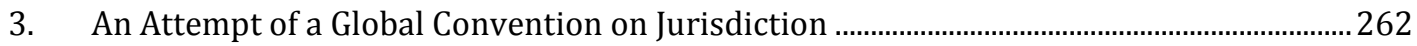

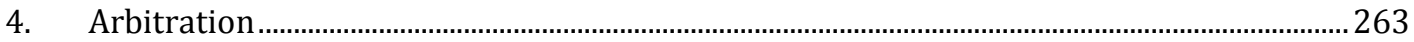

5. Jurisdiction and Enforcement Aspects of Aggregate Litigation .............................................264 

A. Contract
B. Tort
C. Applicable Law in Arbitration.
D. Applicable Law in Aggregate Litigation with Transnational Elements

3. The Public Policy Question 275
A. Public Policy and Securities Disputes.
B. Public Policy and Notice in Aggregate Litigation
C. Public Policy and Arbitrability of Securities Disputes
D. Public Policy and Arbitration based on Corporate Charters.

4. Implications for Securities Disputes .286

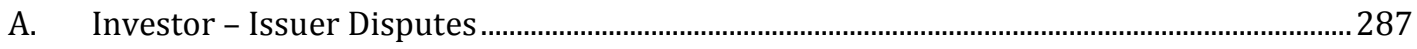
a. Exchange-based.
b. Open Market

B. Investor - Financial Intermediary Disputes

a. Investor Acts Towards Financial Intermediary

b. Financial Intermediary Acts Towards Investor

C. Investor - Informational Intermediary Disputes

5. Final Considerations on the Transnational Aspects of Securities Disputes .296

\section{CHAPTER XI - BUILDING A TRANSNATIONAL SECURITIES DISPUTE RESOLUTION}

1. Problems with Transnational Dispute Resolution of Securities Transactions 298

A. The Legal Infrastructure for Securities Dispute Resolution 299

B. Access to a Dispute Resolution System. 


\section{Dispute Resolution Systems in Transnational Securities Transactions - Institutional}

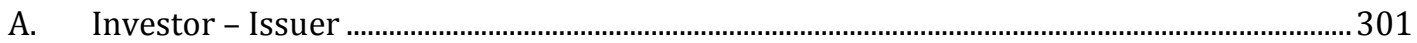

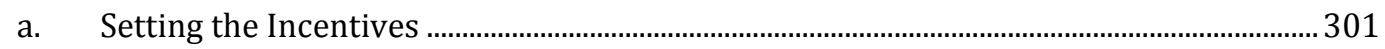

b. Overcoming the Prohibition of Opt-Out Aggregate Litigation...............................................303

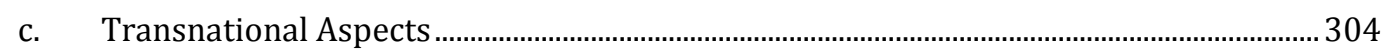

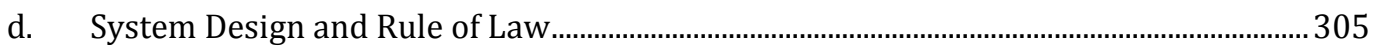

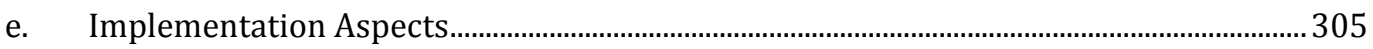

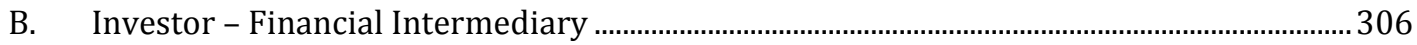

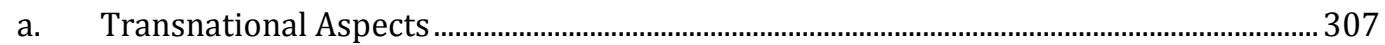

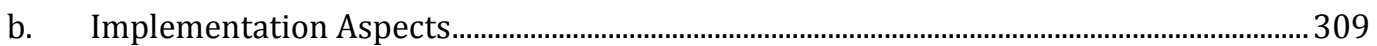

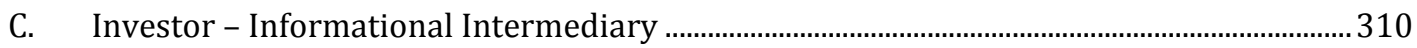

3. Two Systems for Transnational Dispute Resolution of Securities Transactions312

A. Aggregate Litigation Through Arbitration .................................................................................... 313

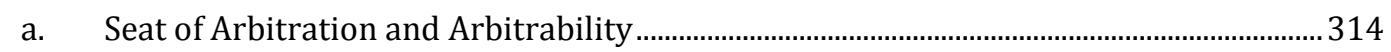

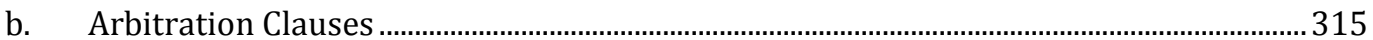

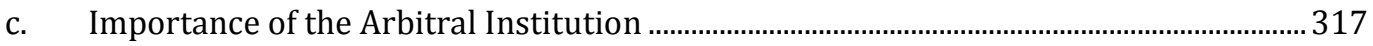

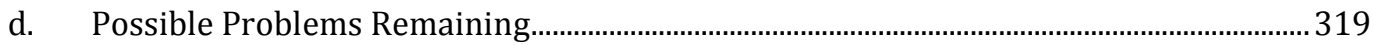

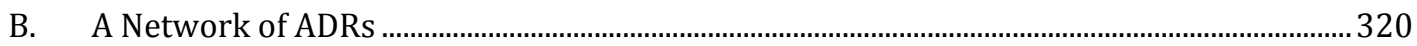

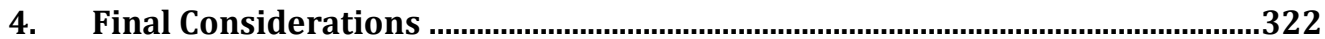




\section{Acknowledgments}

I remember when I was about 23 years old, sitting at the lunch table and discussing with my Dad the next steps in my career. It was my last year in law school and my dream was to pursue the path of Academia and become a PhD before I turned thirty. At that point, I had no idea how I would achieve this, and looking back today from what I wanted at that point in time, my experience at EUI and the thesis resulting from it is actually more than what I dreamed about - I had never imagined receiving my PhD from an institution like the EUI.

The completion of my thesis was only possible because of the people that were in my life through this process. I would like to thank my family, for supporting my choices and being present whenever I needed them; my supervisors, for standing by me in difficult situations and guiding me through the complicated process of writing a thesis; my friends, for their company throughout these four years, making the whole enterprise much more enjoyable; and finally, my fiancée, for the support that she gave me, both academically and on a personal level.

I would also like to thank the Spanish Government, who provided the funding for my $\mathrm{PhD}$, allowing me to dedicate four years of my life to research. 


\section{Table of Cases}

\section{Brazil}

American Home Assurance Company v Braspetro Oil Services Company (ST], $4^{\text {th }}$ Chamber, REsp 251438 / RJ) (2000)

Asa Administradora de Bens v ABN Amro Bank (TJSP, 5th Private Law Chamber, Civil Appeal n. 9247433-87.2005.8.26.000) (2011)

CZ6 Empreendimentos Comerciais Ltda. V Lúcio Maciel (TJRJ, 15 ${ }^{\text {th }}$ Chamber, Civil Appeal n. 2008.001.30250) (2008)

Defensoria Pública da União v Caixa Econômica Federal (4th Federal Court of Porto Alegre, Statement of Claim Acceptance in Public Civil Action n. 500837942.2014.404.7100) (04 February 2014)

Defensoria Pública da União v União - Fazenda Nacional (14th Federal Court of Porto Alegre, Relief Anticipation in Public Civil Action n. 5019819-69.2013.404.7100) (10 May 2013)

General Eletric Company v Varig S.A. (STJ, Special Chamber, SEC 646 / US) (2008)

Luiz Gonzaga Murat Junior v Justiça Pública (TRF3, 5 ${ }^{\text {th }}$ Chamber, Criminal Appeal 45484) (2013)

M.B.V. Commercial and Export Management Establishment v Resil Industria e Comercio Ltda (STF, SE 5206 AgR) (2004)

Ministério Público do Estado de São Paulo v Comind Empreendimentos S.A. (ST], $3^{\text {rd }}$ Chamber, REsp 8878 / SP) (2002)

Queensland Cotton Corporation Ltd. v Agropastoril Jotabasso Ltda. (STJ, Special Chamber, SEC 6753 / EX) (2013)

RS Components Limited v RS do Brasil Comércio Importação Exportação Ltda. (STJ, $3^{\text {rd }}$ Chamber, REsp 804306 / SP) (2008) 
Telebrás S.A. v Ministério Público Federal (TRF1, 2nd Chamber, Civil Appeal n. 93.01.04391-2 / DF) (1995)

Telesp v Ministério Público (TJSP, $7^{\text {th }}$ Private Law Chamber, Instrument Appeal n. 0013965-80.2002.8.26.0000) (2002)

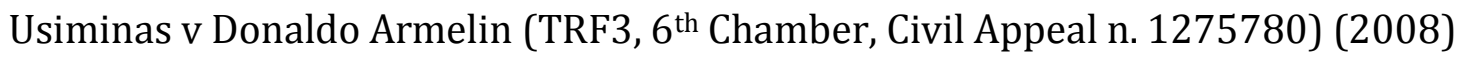

Usiminas v Ministério Público Federal (TRF3, 6 ${ }^{\text {th }}$ Chamber, Instrumental Appeal $n$. 212476) (2004)

Walter Appel v Ministério Público (TJSP, $8^{\text {th }}$ Private Law Chamber, Instrument Appeal n. 9034921-85.2007.8.26.0000) (2007)

World Company Dance Show v Patrícia Chélida de Lima Santos (ST), $4^{\text {th }}$ Chamber, REsp 1168547 / RJ) (2010)

\section{European Court of Human Rights}

Ashingdane v the United Kingdom (1985) Series A no 93

Lithgow and Others v the United Kingdom (1986) Series A no 102

Tinnelly \& Sons Ltd and Others and McElduff and Others v the United Kingdom ECHR 1998-IV

\section{European Court of Justice}

Asturcom Telecomunicaciones v Cristina Rodriguez (Case C-40/08) [2009] ECR I09579

Bier v Mines de Potasse d'Alsace (Case C-21/76) [1976] ECR 01735

Eco Swiss China Time Ltd. V Benetton International NV (Case C-126/97) [1999] ECR I-3055

Gambazzi v DaimlerChrysler (Case C-394/07) [2009] ECR I-02563 
Gasser v MISAT (Case C-116/02) [2003] ECR I-14693

Genil 48 SL v Bankinter (Case C-604/11) (ECJ $4^{\text {th }}$ Chamber, 30 May 2013)

Hirmann v Immofinanz AG (Case C-174/12) (ECJ 2 ${ }^{\text {nd }}$ Chamber, 19 December 2013)

Josi v UGIC (Case C-412/98) [2000] ECR I-05925

Köbler v Republik Österreich (Case C-224/01) [2003] ECR I-2039

Krombach v Bamberski (Case C-7/98) [2000] ECR I-1395

Kronhofer v Maier (Case C-168/02) [2004] ECR I-06009

Mostaza Claro v Centro Móvil (Case C-168/05) [2006] ECR I-10421

Oceano Editorial v Roció Quintero (Case C-240/98) [2000] ECR I-04941

Owusu v Jackson (Case C-281/02) [2005] ECR I-01383

Pubblico Ministero v Tullio Ratti (Case C-148/78) [1979] ECR 1629

Renault v Maxicar SpA (Case C-38/98) [2000] ECR I-02973

Réunion Européennee SA v Spliethoff's Becrachtingskantoor BV (Case C-51/97) [1998] ECR I-6534

Rewe-Zentral AG v Bundesmonopolverwaltung für Branntwein (Cassis de Dijon) (Case C-120/78) [1979] ECR 649

Roche v Primus (Case C-539/03) [2006] ECR I-06535

Rosmarie Kapferer v Schlank \& Schick GmbH (Case C-234/04) [2006] ECR I-2585

Turner v Grovit (Case C-159/02) [2004] ECR I-03565

Van Duyn v Home Office (Case C-41/74) [1975]ECR 1337

\section{The Netherlands}

Converium Settlement, NJ 2010, 683, NIPR 2011, 85 (Court of Appeal Amsterdam 12 November 2010) 
Converium Settlement, no. 200.070.039/01, LJN: BV1026 (Court of Appeal Amsterdam 17 January 2012)

Shell Petroleum N.V. Settlement, LJN: BI 5744, NIPR 2010, 71 (Court of Appeal Amsterdam 29 May 2009)

\section{Spain}

Tribunal Supremo Sentencia n. 244/2013 (RJ 2013/3387), AP Madrid (Sección 20a), sentencia n. 427/2013 (AC 2014/156)

\section{$\underline{\text { UK }}$}

Al Saudi Banque v Clarke Pixley [1990] Ch 313

Belmont Park Investments PTY Limited v BNY Corporate Trustee Services Limited, [2011] UKSC 38

Bigge v Parkinson [1862] 7 H.\&N.955, 158 E.R.758

Brown v Vermuden, 22 Eng. Rep. 796 (Ch. 1676)

Caparo Industries v Dickman and others [1990] 1 All ER 568

Financial Ombudsman Service DRN 1570597

Financial Ombudsman Service DRN 191087

Financial Ombudsman Service DRN 3824818

James McNaughton Papers v Hicks Anderson Court [1991] 1 All ER 134

Jones v Just [1868] L.R. 3 Q.B. 197

Minister of the Interior v Cohn-Bendit [1980] 1 CMLR 543 


\section{$\underline{\mathbf{U S}}$}

American Express Co. v Italian Colors Restaurant, 133 S. Ct. 2304 (2013)

APA Excelsior III L.P. v Premiere Technologies Inc., 476 F.3d 1261 (11 th Cir. 2007)

AT\&T Mobility v Concepcion, 536 U.S. 321 (2011)

Baesler v Cont'l Grain Co., 900 F.2d 1193 (8 ${ }^{\text {th }}$ Cir. 1990)

Baker v General Motors Corp., 522 U.S. 222 (1998)

Basic Inc. v Levinson, 485 U.S. 224 (1988)

Berner v British Commonwealth Pac. Airlines, 346 F.2d 532 (2 ${ }^{\text {nd }}$ Cir. 1965)

Birnbaum v Newport Steel Corp., 193 F.2d 461 (2 ${ }^{\text {nd }}$ Cir. 1952)

Blonder-Tongue Laboratories, Inc. v University of Illinois Foundation, 402 U.S. 313 (1971)

Blue Chip Stamps v Manor Drug Stores, 421 U.S. 723 (1975)

Bonny v Society of Lloyd's, 3 F.3d 156 (1993)

Brown v Ticor Title Insurance Co., 982 F.2d 386 (9th Cir. 1992)

Burke v Kleiman, 277 Ill.App. 519 (1934)

Burnham v Superior Court of California, 495 U.S. 604 (1990)

Central Bank of Denver, N.A. v First Interstate Bank of Denver, N.A., 511 U.S. 164 (1944)

Champ v Siegel Trading Co., 55 F.3d 269 (7th Cir. 1995)

Cheng v Oxford Health Plans, Inc., 2005 WL 5359732 (N.Y. Sup. Ct. N.Y. Co. 5 December 2006)

Cheng v Oxford Health Plans, Inc., 45 App.Div.3d 356 (1 $1^{\text {st }}$ Dept. 2007)

City of Pontiac v UBS AG, No. 12-4355-cv (2 ${ }^{\text {nd }}$ Cir. May 2014)

Dabit v Merrill Lynch, 547 U.S. 71 (2006) 
Dominium Austin Partners, LLC v Emerson, 248 F.3d 720 (8 ${ }^{\text {th }}$ Cir. 2001)

Dun \& Bradstreet, Inc. v Greenmoss Builders, 472 U.S. 749 (1985)

Dura Pharmaceuticals, Inc. v Broudo, 544 U.S. 336 (2005)

Eisen v Carlisle \& Jacquelin, 417 U.S. 156 (1974)

Erie Railroad Co. v Tompkins, 304 U.S. 64 (1938)

F. Hoffmann-La Roche Ltd. v Empagran, 542 U.S. 155 (2004)

Farmers High Line Canal v City of Golden, 975 P.2d 189 (1999)

General Telephone Co. of the Southwest v Falcon, 457 U.S. 147 (1982)

General Telephone Co. v Falcon, 457 U.S. 147 (1982)

Green Tree v Bazzle, 539 U.S. 444 (2003)

Gulf Oil Corp. v Gilbert, 330 U.S. 501 (1947)

Hansberry v Lee, 311 U.S. 32 (1940)

Hartford Fire Insurance Co. v California, 509 U.S. 764 (1993)

Herman \& Maclean v Huddleston, 459 U.S. 375 (1983)

Hilton v Guyot, 159 U.S. 113 (1895)

Huddleston v Herman \& Maclean, 640 F.2d 534 (5th Cir. 1981)

In re AOL Time Warner, Inc., Sec. and ERISA Litigation, 381 F.Supp.2d 192 (S.D.N.Y. 2004)

In re Complete Management Inc., Sec. Litigation, 153 F.Supp.2d 314 (S.D.N.Y. 2001)

In re Enron Corp, Sec., Derivative \& ERISA Litigation, 511 Supp.2d 742 (S.D. Tex. 2005)

In re Merck \& Co., Inc. Securities Litigation, 432 F.3d 261 (3 ${ }^{\text {rd }}$ Cir. 2005)

In re Scottish RE Group Securities Litigation, 524 F. Supp.2d 370 (S.D.N.Y. 2007) 
In Refco, Inc. Sec. Litigation, 503 F. Supp.2d, 611 ((S.D.N.Y. 2007)

Initial Public Offerings Securities Litigation, 471 F.3d 24 (2nd Cir. 2006)

International Shoe Co. v Washington, 326 U.S. 310 (1945)

JSC Surgutneftegaz v President and Fellows of Harvard College, 2007 WL 3019234 (S.D.N.Y. Oct. 11, 2007)

Kardon v National Gypsum Co., 69 F.Supp. 512 (D.C. Pa. 1946)

Kasper Wire Works, Inc. v Leco Eng'g \& Mach, Inc., 575 F.2d 530 (5th Cir. 1978)

Keating v Superior Court, 645 P.2d 1192 (Cal. 1982)

Koster v (American) Lumbermens Mutual Casualty Co., 330 U.S. 518 (1947)

Kremer v Chem. Constr. Corp., 456 U.S. 461 (1982)

Laker Airways Ltd. V Sabena, Belgian World Airlines, 731 F.2d 909 (D.C. 1984)

Lee v Hansberry, 372 Ill. 369, 24 N.E.2d 37 (1939)

Lehman Brothers Holdings Inc. v BNY Corporate Trustee, 422 B.R. 407 (S.D.N.Y. 2010)

Lehman Brothers v. BNY Corporate Trustee, 422 B.R. 407 (S.D.N.Y. 2010)

Lewis v Circuit City Stores, Inc., 500 F.3d 1140 (10 ${ }^{\text {th }}$ Cir. 2007)

Mace v Van Ru Credit Corp., 109 F.3d 338 (7th Cir 1997)

Maclean v Huddleston, 459 U.S. 375 (1983)

Martin v Wilks, 490 U.S. 755 (1989)

McLean v Alexander, 599 F.2d 1190 (3rd Cir. 1979)

Mitsubishi v Soler Chrysler-Plymouth Inc., 473 U.S. 614 (1985)

Montana v United States, 440 U.S. 147 (1979)

Morrison v National Australia Bank, 561 U.S. 247 (2010) 
NY Times v Sullivan, 376 U.S. 245 (1964)

O’Brien v City of Syracuse, 429 N.E.2d 1158 (N.Y. 1981)

Oxford Health Plans LLC v Sutter, 133 S. Ct. 2064 (2013)

Parklane Hosiery Co. v Shore, 439 U.S. 322 (1979)

Perkins v Benguet Consolidated Mining Co., 342 U.S. 604 (1952)

Perry v. Thomas, 107 S. Ct. 2520 (1987)

Phillips Petroleum Co. v Shutts, 472 U.S. 797 (1985)

Pinter v Dahl, 486 U.S. 622 (1988)

Piper Aircraft v Reyno, 454 U.S. 235 (1981)

Pomponio v Larsen, 80 Colo. 318 (1926)

Richards v Jefferson County, 517 U.S. 793 (1996)

Richards v. Lloyd's of London, 135 F.3d 1289 (1998)

Roby v Corporation of Lloyd's, 996 F.2d 1353 (1993)

Rothman v Gregor, 220 F.3d 81 (2nd Cir. 2000)

Scherck v Alberto Culver, 417 U.S. 506 (1974)

Seagate Technology II Securities Litigation, 843 F.Supp. 1341 (N.D. Cal. 1994)

SEC v Capital Gains Research Bureau, Inc., 375 U.S. 180 (1963)

SEC v Goldman Sachs, WL 2305988 (S.D.N.Y. 2011)

Smith v Swormstedt, 57 U.S. 288 (1853)

Stolt-Nielsen S.A. v Animalfeeds Int'l Corp, 435 F.Supp.2d 382 (S.D.N.Y. 2006)

Superintendent of Insurance v Bankers Life \& Casualty Co, 404 U.S. 6 (1971)

Supreme Tribe of Ben-Hur v Cauble 255 U.S. 356 (1921)

Taylor v Sturgell 552 U.S. 880 (2008) 
Tellabs Inc. v Makor Issues \& Rights Ltd., 551 U.S. 308 (2007)

Triplett v Lowell, 297 U.S. 638 (1936)

TSC Indus, Inc. v Northway, Inc., 426 U.S. 438 (1976)

United States v Aluminum Co. of America, 148 F.2d 416 (2 ${ }^{\text {nd }}$ Cir. 1945)

Vernon v Drexel Burnham \& Company, 52 Cal.App.3d 706 (Cal. 1975)

Weaver, Bennett \& Bland, P.A. v Speedy Bucks, Inc., 162 F.Supp.2d 448 (W.D.N.C. 2001)

Wilko v Swan, 346 U.S. 427 (1953)

World-Wide Volkswagen v Woodson, 444 U.S. 286 (1980)

\section{$\underline{\text { Other Jurisdictions }}$}

Bathurst Regional Council v Local Government Financial Services Pty Ltd. (No 5)[2012] FCA 1200 (Australia) 


\section{Table of Legislation, Treaties and Other Materials}

Short Format

Full Citation

\begin{tabular}{|c|c|}
\hline Brazilian Federal Constitution & $\begin{array}{l}\text { Constituição da República Federativa do } \\
\text { Brasil de } 1988\end{array}$ \\
\hline Decree-Law 4.657/1942 & $\begin{array}{l}\text { Decreto-Lei No 4.657, de } 4 \text { de Setembro de } \\
1942 \text { (Lei de Introdução às normas do Direito } \\
\text { Brasileiro) }\end{array}$ \\
\hline Instruction CVM 306 & $\begin{array}{l}\text { Instrução CVM No 306, de } 5 \text { de maio de } 1999 \\
\text { (Dispõe sobre a administração de carteira de } \\
\text { valores mobiliários e revoga as Instruções } \\
\text { CVM nos } 82 \text {, de } 19 \text { de setembro de } 1988 \text {; } 94 \text {, } \\
\text { de } 4 \text { de janeiro de } 1989 \text { e } 231 \text {, de } 16 \text { de } \\
\text { janeiro de } 1995 \text { ) }\end{array}$ \\
\hline Instruction CVM 358 & $\begin{array}{l}\text { Instrução CVM No 358, de } 3 \text { de Janeiro de } \\
2002 \text { (Dispõe sobre a divulgação e uso de } \\
\text { informações sobre ato ou fato relevante } \\
\text { relativo às companhias abertas, disciplina a } \\
\text { divulgação de informações na negociação de } \\
\text { valores mobiliários e na aquisição de lote } \\
\text { significativo de ações de emissão de } \\
\text { companhia aberta, estabelece vedações e } \\
\text { condições para a negociação de ações de } \\
\text { companhia aberta na pendência de fato } \\
\text { relevante não divulgado ao mercado, revoga } \\
\text { a Instrução CVM no } 31 \text {, de } 8 \text { de fevereiro de }\end{array}$ \\
\hline
\end{tabular}




\begin{tabular}{|c|c|}
\hline & $\begin{array}{l}\text { 1984, a Instrução CVM no } 69 \text {, de } 8 \text { de } \\
\text { setembro de } 1987 \text {, o art. 3o da Instrução } \\
\text { CVM no } 229 \text {, de } 16 \text { de janeiro de } 1995 \text {, o } \\
\text { parágrafo único do art. } 13 \text { da Instrução CVM } \\
\text { 202, de } 6 \text { de dezembro de } 1993 \text {, e os arts. } 30 \\
\text { a } 11 \text { da Instrução CVM no } 299 \text {, de } 9 \text { de } \\
\text { fevereiro de } 1999 \text {, e dá outras providências) }\end{array}$ \\
\hline Instruction CVM 400 & $\begin{array}{l}\text { Instrução CVM № 400, de } 29 \text { de Dezembro } \\
\text { de } 2003 \text { (Dispõe sobre as ofertas públicas de } \\
\text { distribuição de valores mobiliários, nos } \\
\text { mercados primário ou secundário, e revoga } \\
\text { a Instrução CVM no 13, de } 30 \text { de setembro } \\
\text { de } 1980 \text {, e a Instrução CVM no } 88 \text {, de } 3 \\
\text { novembro de 1988) }\end{array}$ \\
\hline Instruction CVM 461 & 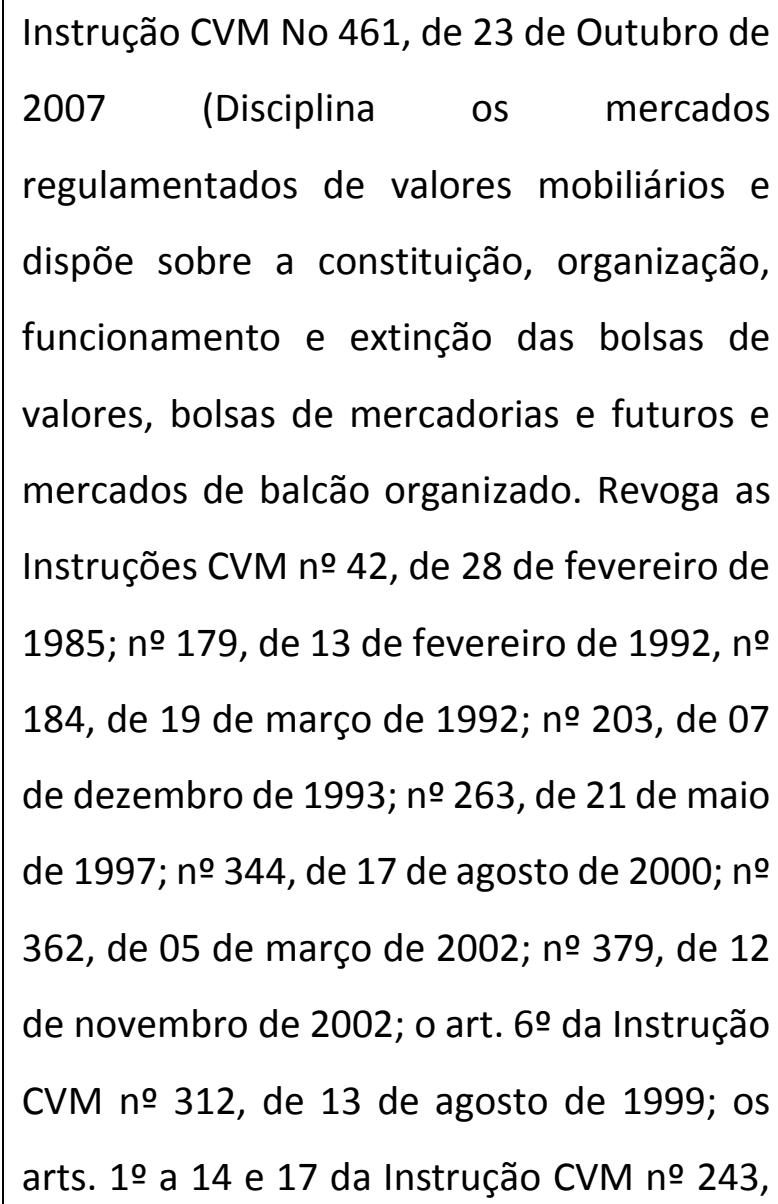 \\
\hline
\end{tabular}




\begin{tabular}{|c|c|}
\hline & 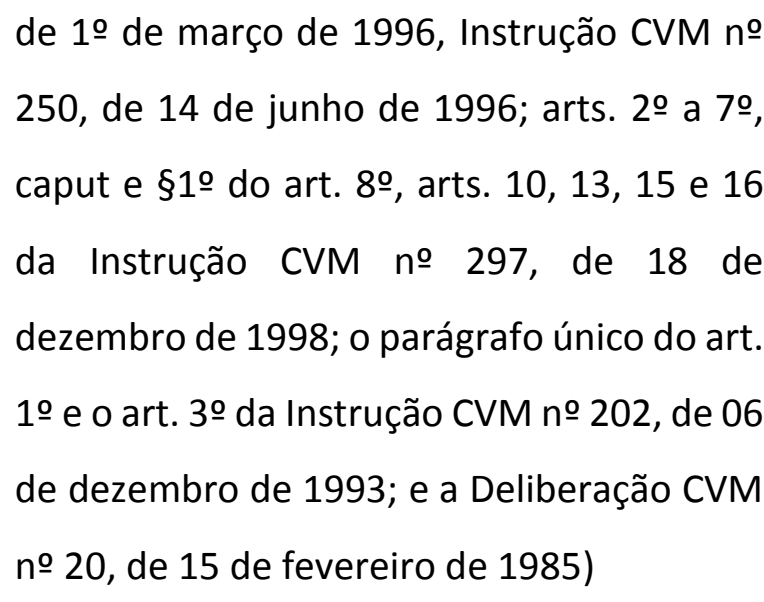 \\
\hline Instruction CVM 497 & $\begin{array}{l}\text { Instrução CVM № 497, de } 3 \text { de Junho de } \\
2001 \text { (Dispõe sobre a atividade de agente } \\
\text { autônomo de investimento) }\end{array}$ \\
\hline Law 10.303/2001 & $\begin{array}{l}\text { Lei No } 10.303 / 2001 \text { (Altera e acrescenta } \\
\text { dispositivos na Lei no } 6.404 \text {, de } 15 \text { de } \\
\text { dezembro de 1976, que dispõe sobre as } \\
\text { Sociedades por Ações, e na Lei no } 6.385 \text {, de } \\
7 \text { de dezembro de } 1976 \text {, que dispõe sobre o } \\
\text { mercado de valores mobiliários e cria a } \\
\text { Comissão de Valores Mobiliários) }\end{array}$ \\
\hline $\begin{array}{l}\text { Law 10.406/2002 [Brazilian Civil } \\
\text { Code] }\end{array}$ & $\begin{array}{l}\text { Lei No 10.406, de } 10 \text { Janeiro de } 2002 \text { (Institui } \\
\text { o Código Civil) }\end{array}$ \\
\hline Law 4.717/65 & $\begin{array}{l}\text { Lei No 4.717, de } 29 \text { de Junho de } 1965 \text { (Regula } \\
\text { a ação popular) }\end{array}$ \\
\hline $\begin{array}{l}\text { Law 5.869/1973 [Brazilian Civil } \\
\text { Procedure Code] }\end{array}$ & $\begin{array}{l}\text { Lei No 5.869, de } 11 \text { de Janeiro de } 1973 \\
\text { (Institui o Código de Processo Civil) }\end{array}$ \\
\hline Law 6.385/76 & $\begin{array}{l}\text { Lei No 6.385, de } 7 \text { de Dezembro de } 1976 \\
\text { (Dispõe sobre o mercado de valores } \\
\text { mobiliários e cria a Comissão de Valores } \\
\text { Mobiliários) }\end{array}$ \\
\hline
\end{tabular}




\begin{tabular}{|c|c|}
\hline Law 6.404/1976 & $\begin{array}{l}\text { Lei No 6.404, de } 15 \text { de dezembro de } 1976 \\
\text { (Dispõe sobre as sociedades por ações) }\end{array}$ \\
\hline Law 6.404/76 & $\begin{array}{l}\text { Lei No 6.404, de } 15 \text { de dezembro de } 1976 \\
\text { (Dispõe sobre as Sociedades por Ações) }\end{array}$ \\
\hline Law 7.244/1984 & $\begin{array}{l}\text { Lei No } 7.244 \text {, de } 7 \text { de Novembro de } 1984 \\
\text { (Dispõe sobre a criação e o funcionamento } \\
\text { do Juizado Especial de Pequenas Causas) }\end{array}$ \\
\hline Law 7.347/1985 & $\begin{array}{l}\text { Lei No 7.347, de } 24 \text { de julho de } 1985 \\
\text { (Disciplina a ação civil pública de } \\
\text { responsabilidade por danos causados ao } \\
\text { meio-ambiente, ao consumidor, a bens e } \\
\text { direitos de valor artístico, estético, histórico, } \\
\text { turístico e paisagístico e dá outras } \\
\text { providências) }\end{array}$ \\
\hline Law 7.853/89 & $\begin{array}{l}\text { Lei No } 7.853 / 1989 \text { (Dispõe sobre o apoio às } \\
\text { pessoas portadoras de deficiência, sua } \\
\text { integração social, sobre a Coordenadoria } \\
\text { Nacional para Integração da pessoa } \\
\text { Portadora de Deficiência - CORDE, institui a } \\
\text { tutela jurisdicional de interesses coletivos ou } \\
\text { difusos dessas pessoas, disciplina a atuação } \\
\text { do Ministério Público, define crimes, e dá } \\
\text { outras providências) }\end{array}$ \\
\hline Law 7.913/89 & $\begin{array}{l}\text { Lei } 7.913 \text {, de } 7 \text { de dezembro de } 1989 \text { (Dispõe } \\
\text { sobre a ação civil pública de } \\
\text { responsabilidade por danos causados aos } \\
\text { investidores no mercado de valores } \\
\text { mobiliários) }\end{array}$ \\
\hline
\end{tabular}




\begin{tabular}{|c|c|}
\hline Law 8.069/90 & $\begin{array}{l}\text { Lei 8.069, de } 13 \text { de Julho de } 1990 \text { (Dispõe } \\
\text { sobre o Estatuto da Criança e do } \\
\text { Adolescente e dá outras providências) }\end{array}$ \\
\hline $\begin{array}{l}\text { Law 8.078/1990 [Brazilian Consumer } \\
\text { Defense Code] }\end{array}$ & $\begin{array}{l}\text { Lei No } 8.078 \text {, de } 11 \text { de Setembro de } 1990 \\
\text { (Dispõe sobre a proteção do consumidor e } \\
\text { dá outras providências) }\end{array}$ \\
\hline Law 8.906/1994 & $\begin{array}{l}\text { Lei No 8.906, de } 4 \text { de julho de } 1994 \text { (Dispõe } \\
\text { sobre o Estatuto da Advocacia e a Ordem dos } \\
\text { Advogados do Brasil) }\end{array}$ \\
\hline Law 9.307/1996 & $\begin{array}{l}\text { Lei No 9.307, de } 23 \text { de setembro de } 1996 \\
\text { (Dispõe sobre a arbitragem) }\end{array}$ \\
\hline Resolution STJ 9 [2005] & Resolução No 9, de 4 de maio de 2005 \\
\hline Resolution TJMS 564 (2010) & $\begin{array}{l}\text { Resolução No 564, de } 17 \text { de Fevereiro de } \\
\text { 2010, Tribunal de Justiça de Mato Grosso do } \\
\text { Sul (Fixa em reais os valores das gratificações } \\
\text { a serem pagas aos conciliadores e juízes } \\
\text { leigos dos Juizados Especiais Cíveis e } \\
\text { Criminais do Estado de Mato Grosso do Sul, } \\
\text { e dá outras providências) }\end{array}$ \\
\hline Supplementary Law 35/1979 & $\begin{array}{l}\text { Lei Complementar No 35, de } 14 \text { de Março de } \\
1979 \text { (Dispões sobre a Lei Orgânica da } \\
\text { Magistratura Nacional) }\end{array}$ \\
\hline
\end{tabular}

\section{EU}

Regulation (EU) No 1215/2012 of the European Parliament and of the Council of 12 December 2012 on jurisdiction and the 


\begin{tabular}{|c|c|}
\hline & $\begin{array}{l}\text { recognition and enforcement of judgments } \\
\text { in civil and commercial matters (recast) } \\
\text { [2012] OJ L351/1 }\end{array}$ \\
\hline $\begin{array}{l}\text { Charter of Fundamental Rights of the } \\
\text { European Union }\end{array}$ & $\begin{array}{l}\text { Charter of Fundamental Rights of the } \\
\text { European Union [2000] OJ C364/1 }\end{array}$ \\
\hline $\begin{array}{l}\text { Commission } \\
\text { 2008/961/EC }\end{array}$ & $\begin{array}{l}\text { Commission Decision of } 12 \text { December } 2008 \\
\text { on the use by third countries' issuers of } \\
\text { securities of certain third country's national } \\
\text { accounting standards and International } \\
\text { Financial Reporting Standards to prepare } \\
\text { their consolidated financial statements } \\
\text { [2008] OJ L340/112 }\end{array}$ \\
\hline $\begin{array}{l}\text { Commission Delegated Regulation } \\
\text { (EU) } 486 / 2012\end{array}$ & $\begin{array}{l}\text { Commission Delegated Regulation (EU) } \\
\text { No } 486 / 2012 \text { of } 30 \text { March } 2012 \text { amending } \\
\text { Regulation (EC) No } 809 / 2004 \text { as regards } \\
\text { the format and the content of the } \\
\text { prospectus, the base prospectus, the } \\
\text { summary and the final terms and as } \\
\text { regards the disclosure requirement } \\
\text { [2012] 0J L150/1 }\end{array}$ \\
\hline $\begin{array}{l}\text { Commission Delegated Regulation } \\
\text { (EU) } 759 / 2013\end{array}$ & $\begin{array}{l}\text { Commission Delegate Regulation (EU) No } \\
759 / 2013 \text { of } 30 \text { April } 2013 \text { amending } \\
\text { Regulation (EC) No } 809 / 2004 \text { as regards } \\
\text { the disclosure requirements for } \\
\text { convertible and exchangeable debt } \\
\text { securities [2013] OJ L } 213 / 1\end{array}$ \\
\hline $\begin{array}{l}\text { Commission Delegated Regulation } \\
\text { (EU) } 862 / 2012\end{array}$ & $\begin{array}{l}\text { Commission Delegated Regulation (EU) } \\
\text { No } 862 / 2012 \text { of } 4 \text { June } 2012 \text { amending } \\
\text { Regulation (EC) No } 809 / 2004 \text { as regards } \\
\text { information on the consent to use of the }\end{array}$ \\
\hline
\end{tabular}




\begin{tabular}{|c|c|c|}
\hline & & $\begin{array}{l}\text { prospectus, information on underlying } \\
\text { indexes and the requirement for a report } \\
\text { prepared by independent accountants or } \\
\text { auditors [2012] OJ L 256/4 }\end{array}$ \\
\hline $\begin{array}{l}\text { Commission } \\
\text { 2003/124/EC }\end{array}$ & Directive & $\begin{array}{l}\text { Commission Directive 2003/124/EC of } 22 \\
\text { December } 2003 \text { implementing Directive } \\
2003 / 6 / \text { EC of the European Parliament } \\
\text { and of the Council as regards the definition } \\
\text { and public disclosure of inside } \\
\text { information and the definition of market } \\
\text { manipulation [2003] OJ L339/70 }\end{array}$ \\
\hline $\begin{array}{l}\text { Commission } \\
\text { 2003/125/EC }\end{array}$ & Directive & $\begin{array}{l}\text { Commission Directive 2003/125/EC of } 22 \\
\text { December } 2003 \text { implementing Directive } \\
2003 / 6 / E C \text { of the European Parliament } \\
\text { and of the Council as regards the fair } \\
\text { presentation investment } \\
\text { recommendations and the disclosure of } \\
\text { conflicts of interest [2003] 0J L339/73 }\end{array}$ \\
\hline $\begin{array}{l}\text { Commission } \\
\text { 2004/72/EC }\end{array}$ & Directive & $\begin{array}{l}\text { Commission Directive 2004/72/EC of } 29 \\
\text { April } 2004 \text { implementing Directive } \\
2003 / 6 / \mathrm{EC} \text { of the European Parliament } \\
\text { and of the Council as regards accepted } \\
\text { market practices, the definition of inside } \\
\text { information in relation to derivatives on } \\
\text { commodities, the drawing up of lists of } \\
\text { insiders, the notification of managers' } \\
\text { transactions and the notification of } \\
\text { suspicious transactions [2004] OJ } \\
\text { L162/70 }\end{array}$ \\
\hline $\begin{array}{l}\text { Commission } \\
\text { 2006/73/EC }\end{array}$ & Directive & $\begin{array}{l}\text { Commission Directive } 2006 / 73 / \text { EC of } 10 \\
\text { August } 2006 \text { implementing Directive }\end{array}$ \\
\hline
\end{tabular}




\begin{tabular}{|c|c|c|}
\hline & & $\begin{array}{l}2004 / 39 / \mathrm{EC} \text { of the European Parliament } \\
\text { and the Council as regards organizational } \\
\text { requirements and operating conditions } \\
\text { for investment firms and defined terms for } \\
\text { the purposes of that Directive [2006] OJ } \\
\text { L241/26 }\end{array}$ \\
\hline $\begin{array}{l}\text { Commission } \\
\text { 2007/14/EC }\end{array}$ & Directive & $\begin{array}{l}\text { Commission Directive } 2007 / 14 / \mathrm{EC} \text { of } 8 \\
\text { March } 2007 \text { laying down detailed rules for } \\
\text { the implementation of certain provisions } \\
\text { of Directive 2004/109/EC on the } \\
\text { harmonization of transparency } \\
\text { requirements in relation to information } \\
\text { about issuers whose securities are } \\
\text { admitted to trading on a regulated market } \\
\text { [2007] 0J L69/7 }\end{array}$ \\
\hline $\begin{array}{l}\text { Commission } \\
\text { 2013/396/EU }\end{array}$ & Recommendation & $\begin{array}{l}\text { Commission Recommendation } \\
\text { (2013/396/EU) of } 11 \text { June } 2013 \text { on common } \\
\text { principles for injunctive and compensatory } \\
\text { collective redress mechanisms in the } \\
\text { Member States concerning violations of } \\
\text { rights granted under Union Law [2013] OJ } \\
\text { L201/60 }\end{array}$ \\
\hline $\begin{array}{l}\text { Commission } \\
1287 / 2006\end{array}$ & Regulation & $\begin{array}{l}\text { Commission } \text { Regulation (EC) No } \\
1287 / 2006 \text { of } 10 \text { August } 2006 \\
\text { implementing Directive } 2004 / 39 / \text { EC of } \\
\text { the European Parliament and of the } \\
\text { Council as regards record-keeping } \\
\text { obligations for investment firms, } \\
\text { transaction reporting, market } \\
\text { transparency, admission of financial } \\
\text { instruments to trading, and defined terms }\end{array}$ \\
\hline
\end{tabular}




\begin{tabular}{|c|c|c|}
\hline & & $\begin{array}{l}\text { for the purpose of that Directive [2006] OJ } \\
\text { L241/1 }\end{array}$ \\
\hline $\begin{array}{l}\text { Commission } \\
1569 / 2007\end{array}$ & Regulation & 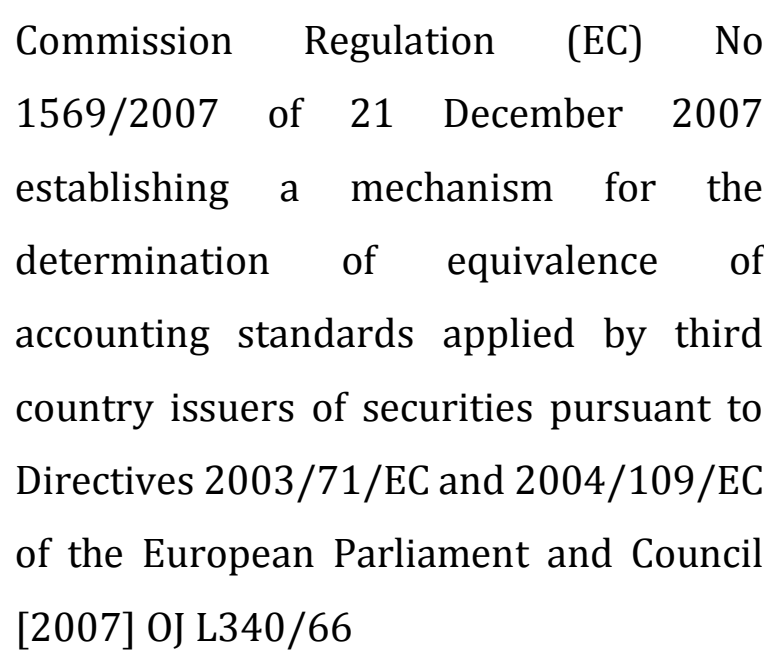 \\
\hline $\begin{array}{l}\text { Commission } \\
211 / 2007\end{array}$ & Regulation & $\begin{array}{l}\text { Commission Regulation (EC) No } \\
211 / 2007 \text { of } 27 \text { February } 2007 \text { amending } \\
\text { Regulation (EC) No } 809 / 2004 \\
\text { implementing Directive } 2003 / 71 / \text { EC of } \\
\text { the European Parliament and of the } \\
\text { Council as regards financial information in } \\
\text { prospectuses where the issuer has a } \\
\text { complex financial history or has made a } \\
\text { significant financial commitment [2007] } \\
\text { 0J L61/24 }\end{array}$ \\
\hline $\begin{array}{l}\text { Commission } \\
2273 / 2003\end{array}$ & Regulation & $\begin{array}{l}\text { Commission Regulation (EC) No } \\
2273 / 2003 \text { of } 22 \text { December } 2003 \\
\text { implementing Directive 2003/6/EC of the } \\
\text { European Parliament and of the Council as } \\
\text { regards exemptions for buy-back } \\
\text { programmes and stabilization of financial } \\
\text { instruments [2003] OJ L336/33 }\end{array}$ \\
\hline $\begin{array}{l}\text { Commission } \\
809 / 2004\end{array}$ & Regulation (EC) No & $\begin{array}{l}\text { Commission Regulation (EC) No 809/2004 of } \\
29 \text { April } 2004 \text { implementing Directive } \\
2003 / 71 / \text { EC of the European Parliament and }\end{array}$ \\
\hline
\end{tabular}




\begin{tabular}{|c|c|}
\hline & $\begin{array}{l}\text { of the Council as regards information } \\
\text { contained in prospectuses as well as the } \\
\text { format, incorporation by reference and } \\
\text { publication of such prospectuses and } \\
\text { dissemination of advertisements [2004] OJ } \\
\text { L149/1 }\end{array}$ \\
\hline $\begin{array}{l}\text { Council Regulation (EC) 44/2001 } \\
\text { [Brussels I Reg] }\end{array}$ & $\begin{array}{l}\text { Council Regulation (EC) No } 44 / 2001 \text { of } 22 \\
\text { December } 2000 \text { on jurisdiction and the } \\
\text { recognition and enforcement of judgments } \\
\text { in civil and commercial matters [2001] OJ } \\
\text { L12/1 }\end{array}$ \\
\hline $\begin{array}{l}\text { Delegated Regulation (EU) } \\
382 / 2014\end{array}$ & $\begin{array}{l}\text { Delegated Regulation (EU) No 382/2014 } \\
\text { of } 7 \text { March } 2014 \text { supplementing Directive } \\
2003 / 71 / \text { EC of the European Parliament } \\
\text { and of the Council with regard to } \\
\text { regulatory technical standards for } \\
\text { publication of supplements to the } \\
\text { prospectus [2014] OJ L111/36 }\end{array}$ \\
\hline $\begin{array}{l}\text { Directive 2003/6/EC [Market } \\
\text { Abuse Directive] }\end{array}$ & $\begin{array}{l}\text { Directive 2003/6/EC of the European } \\
\text { Parliament and Council of } 28 \text { January } \\
2003 \text { on insider dealing and market } \\
\text { manipulation (market abuse) OJ L96/16 }\end{array}$ \\
\hline $\begin{array}{l}\text { Directive 2003/71/EC [Prospectus } \\
\text { Directive] }\end{array}$ & $\begin{array}{l}\text { Directive } 2003 / 71 / E C \text { of the European } \\
\text { Parliament and of the Council of } 4 \text { November } \\
2003 \text { on the prospectus to be published } \\
\text { when securities are offered to the public or } \\
\text { admitted to trading and amending Directive } \\
2001 / 34 / E C \text { OJ } L 345 / 64\end{array}$ \\
\hline
\end{tabular}




\begin{tabular}{|c|c|}
\hline $\begin{array}{l}\text { Directive 2004/109/EC } \\
\text { [Transparency Directive] }\end{array}$ & $\begin{array}{l}\text { Directive } 2004 / 109 / \mathrm{EC} \text { of the European } \\
\text { Parliament and of the Council of } 15 \\
\text { December } 2004 \text { on the harmonization of } \\
\text { transparency requirements in relation to } \\
\text { information about issuers whose } \\
\text { securities are admitted to trading on a } \\
\text { regulated market and amending Directive } \\
2001 / 34 / \text { EC OJ L390/38 }\end{array}$ \\
\hline Directive 2004/39/EC & $\begin{array}{l}\text { Directive 2004/39/EC of the European } \\
\text { Parliament and of the Council of } 21 \text { April } \\
2004 \text { on markets in financial instruments } \\
\text { amending Council Directives } 85 / 611 / E E C \\
\text { and 93/6/EEC and Directive 2000/12/EC of } \\
\text { the European Parliament and of the Council } \\
\text { and repealing Council Directive } 93 / 22 / E E C \\
\text { [2010] OJ L145/1 }\end{array}$ \\
\hline $\begin{array}{l}\text { Directive 2004/39/EC } \\
\text { Directive] }\end{array}$ & $\begin{array}{l}\text { Directive 2004/39/EC of the European } \\
\text { Parliament and of the Council of } 21 \text { April } \\
2004 \text { on markets in financial instruments } \\
\text { amending Council Directives } 85 / 611 / E E C \\
\text { and 93/6/EEC and Directive } 2000 / 12 / E C \text { of } \\
\text { the European Parliament of the Council and } \\
\text { repealing Council Directive 93/22/EEC } \\
\text { [2004] OJ L145/30 }\end{array}$ \\
\hline $\begin{array}{l}\text { Directive 2009/65/EC [UCITS } \\
\text { Directive] }\end{array}$ & $\begin{array}{l}\text { Directive } 2009 / 65 / \text { EC of the European } \\
\text { Parliament and of the Council of } 13 \text { July } \\
2009 \text { on the coordination of laws, } \\
\text { regulations and administrative provisions } \\
\text { relating to undertakings for collective }\end{array}$ \\
\hline
\end{tabular}




\begin{tabular}{|c|c|}
\hline & $\begin{array}{l}\text { investment in transferable securities } \\
\text { (UCITS) [2009] OJ L302/32 }\end{array}$ \\
\hline Directive 2010/73/EU & $\begin{array}{l}\text { Directive } 2010 / 73 / \text { EU of the European } \\
\text { Parliament and of the Council of } 24 \\
\text { November } 2010 \text { amending Directives } \\
2003 / 71 / E C \text { on the prospectus to be } \\
\text { published when securities are offered to } \\
\text { the public or admitted to trading and } \\
2004 / 109 / \text { EC on the harmonization of } \\
\text { transparency requirements in relation to } \\
\text { information about issuers whose } \\
\text { securities are admitted to trading on a } \\
\text { regulated market [2010] 0J L327/1 }\end{array}$ \\
\hline Directive $2013 / 50 / \mathrm{EU}$ & $\begin{array}{l}\text { Directive } 2013 / 50 / E U \text { of the European } \\
\text { Parliament and of the Council of } 22 \\
\text { October } 2013 \text { ameding Directive } \\
2004 / 109 / E C \text { of the European Parliament } \\
\text { and of the Council on the harmonization of } \\
\text { transparency requirements in relation to } \\
\text { information about issuers whose } \\
\text { securities are admitted to trading on a } \\
\text { regulated market, Directive } 2003 / 71 / E C \\
\text { of the European Parliament and of the } \\
\text { Council on the prospectus to be published } \\
\text { when securities are offered to the public or } \\
\text { admitted to trading and Commission } \\
\text { Directive 2007/14/EC laying down } \\
\text { detailed rules for the implementation of } \\
\text { certain provisions of Directive } \\
2004 / 109 / E C \text { [ } 2013 \text { ] OJ L249/13 }\end{array}$ \\
\hline
\end{tabular}




\begin{tabular}{|c|c|}
\hline $\begin{array}{l}\text { European Parliament Resolution } \\
2011 / 2089 \text { (INI) }\end{array}$ & $\begin{array}{l}\text { European Parliament Resolution of } 2 \\
\text { February } 2012 \text { on 'Towards a Coherent } \\
\text { European Approach to Collective Redress' } \\
(2011 / 2089(\text { INI)) }\end{array}$ \\
\hline Regulation (EC) 1060/2009 & $\begin{array}{l}\text { Regulation (EC) No } 1060 / 2009 \text { of the } \\
\text { European Parliament and of the Council of } \\
16 \text { September } 2009 \text { on credit rating } \\
\text { agencies [2009] 0J L302/1 }\end{array}$ \\
\hline Regulation (EC) 1393/2007 & $\begin{array}{l}\text { Regulation (EC) No } 1393 / 2007 \text { of the } \\
\text { European Parliament and of the Council of } \\
13 \text { November } 2007 \text { on the service in the } \\
\text { Member States of judicial and extrajudicial } \\
\text { documents in civil or commercial matters } \\
\text { (service of documents), and repealing } \\
\text { Council Regulation (EC) No } 1348 / 2000 \\
\text { [2007] OJ L324/79 }\end{array}$ \\
\hline Regulation (EC) 593/2008 [Rome I] & $\begin{array}{l}\text { Regulation (EC) No 593/2008 of the } \\
\text { European Parliament and of the Council of } \\
17 \text { June } 2008 \text { on the law applicable to } \\
\text { contractual obligations (Rome I) [2008] OJ } \\
\text { L177/6 }\end{array}$ \\
\hline Regulation (EC) 805/2004 & $\begin{array}{l}\text { Regulation (EC) No } 805 / 2004 \text { of the } \\
\text { European Parliament and of the Council of } \\
21 \text { April } 2004 \text { creating a European } \\
\text { Enforcement Order for uncontested claims } \\
\text { [2004] L143/15 }\end{array}$ \\
\hline Regulation (EC) 861/2007 & $\begin{array}{l}\text { Regulation (EC) No } 861 / 2007 \text { of the } \\
\text { European Parliament and of the Council of }\end{array}$ \\
\hline
\end{tabular}




\begin{tabular}{|c|c|}
\hline & $\begin{array}{l}11 \text { July } 2007 \text { establishing a European Small } \\
\text { Claims Procedure [2007] OJ L199/1 }\end{array}$ \\
\hline Regulation (EC) 864/2007 [Rome II] & $\begin{array}{l}\text { Regulation (EC) No } 864 / 2007 \text { of the } \\
\text { European Parliament and of the Council of } \\
11 \text { July } 2007 \text { on the law applicable to non- } \\
\text { contractual obligations (Rome II) [2007] OJ } \\
\text { L199/40 }\end{array}$ \\
\hline Regulation (EU) 1092/2010 & $\begin{array}{l}\text { Regulation (EU) No 1092/2010 of the } \\
\text { European Parliament and of the Council of } \\
24 \text { November } 2010 \text { on European Union } \\
\text { macro-prudential oversight of the financial } \\
\text { system and establishing a European } \\
\text { Systemic Risk Board [2010] OJ L331/1 }\end{array}$ \\
\hline Regulation (EU) 1093/2010 & $\begin{array}{l}\text { Regulation (EU) No 1093/2010 of the } \\
\text { European Parliament and of the Council of } \\
24 \text { November } 2010 \text { establishing a European } \\
\text { Supervisory Authority (European Banking } \\
\text { Authority), amending Decision No } \\
716 / 2009 / E C \text { and repealing Commission } \\
\text { Decision 2009/78/EC [2010] OJ L331/12 }\end{array}$ \\
\hline Regulation (EU) 1094/2010 & $\begin{array}{l}\text { Regulation (EU) No } 1094 / 2010 \text { of the } \\
\text { European Parliament and of the Council of } \\
24 \text { November } 2010 \text { establishing a European } \\
\text { Supervisory Authority (European Insurance } \\
\text { and Occupational Pensions Authority), } \\
\text { amending Decision No 716/2009/EC and } \\
\text { repealing Commission Decision 2009/79/EC } \\
\text { [2010] OJ L331/48 }\end{array}$ \\
\hline
\end{tabular}




\begin{tabular}{|c|c|}
\hline Regulation (EU) 1095/2010 & $\begin{array}{l}\text { Regulation (EU) No 1095/2010 of the } \\
\text { European Parliament and of the Council of } \\
24 \text { November } 2010 \text { establishing a European } \\
\text { Supervisory Authority (European Securities } \\
\text { and Markets Authority), amending Decision } \\
\text { No 716/2009/EC and repealing Commission } \\
\text { Decision 2009/77/EC [2010] OJ L331/84 }\end{array}$ \\
\hline Regulation (EU) 462/2013 & $\begin{array}{l}\text { Regulation (EU) No } 462 / 2013 \text { of the } \\
\text { European Parliament and of the Council of } \\
21 \text { May } 2013 \text { amending Regulation (EC) No } \\
\text { 1060/2009 on credit rating agencies [2013] } \\
\text { OJ L146/1 }\end{array}$ \\
\hline Regulation (EU) 524/2013 & $\begin{array}{l}\text { Regulation (EU) No 524/2013 of the } \\
\text { European Parliament and of the Council of } \\
21 \text { May } 2013 \text { on online dispute resolution for } \\
\text { consumer disputes and amending } \\
\text { Regulation (EC) No 2006/2004 and Directive } \\
\text { 2009/22/EC (Regulation on consumer ODR) } \\
\text { [2013] OJ L165/1 }\end{array}$ \\
\hline Treaty on European Union [TEU] & $\begin{array}{l}\text { Consolidated Version of The Treaty on } \\
\text { European Union [2012] OJ C326/13 }\end{array}$ \\
\hline $\begin{array}{l}\text { Treaty on the Functioning of the } \\
\text { European Union [TFEU] }\end{array}$ & $\begin{array}{l}\text { Consolidated Version of the Treaty on the } \\
\text { Functioning of the European Union [2012] OJ } \\
\text { C326/47 }\end{array}$ \\
\hline
\end{tabular}

\section{Germany}


Capital Market Investors' Model Proceeding Act [KapMuG]
Gesetz zur Einfiihrung yon KapitalanlegerMusterverfahren-KapMuG, published in the Federal Law Gazette, BGBI 2005 I, at 2437

\section{Private Instruments and Corporate Charters}

\begin{tabular}{|c|c|}
\hline $\begin{array}{l}\text { AAA Supplementary Rules for } \\
\text { Class Arbitration }\end{array}$ & <www.adr.org> accessed 4 July 2014 \\
\hline DIS-Supplementary Rules for & <http://www.dis- \\
\hline $\begin{array}{l}\text { Corporate Law } \quad \text { Disputes } \\
\text { (SRCoLD) }\end{array}$ & $\begin{array}{l}\text { arb.de/en/16/regeln/dis-supplementary- } \\
\text { rules-for-corporate-law-disputes-09- } \\
\text { srcold-id15> accessed } 4 \text { July } 2014\end{array}$ \\
\hline Finra Customer Code & $\begin{array}{l}\text { Code of Arbitration Procedures for Customer } \\
\text { Disputes <www.finra.org> accessed } 03 \text { July } \\
2014\end{array}$ \\
\hline Finra Rules & <www.finra.org> accessed 03 July 2014 \\
\hline $\begin{array}{l}\text { Hague Convention on Choice of } \\
\text { Court Agreements }\end{array}$ & $\begin{array}{l}\text { Convention of } 30 \text { June } 2005 \text { on Choice of } \\
\text { Court Agreements (adopted } 30 \text { June 2005) }\end{array}$ \\
\hline $\begin{array}{l}\text { IBA Guidelines on Conflicts of } \\
\text { Interest (2004) }\end{array}$ & $\begin{array}{l}\text { IBA Guidelines on Conflicts of Interest in } \\
\text { International Arbitration (2004) }\end{array}$ \\
\hline ICC Rules of Arbitration & $\begin{array}{l}\text { <http://www.iccwbo.org/products-and- } \\
\text { services/arbitration-and- } \\
\text { adr/arbitration/icc-rules-of-arbitration/> } \\
\text { (2012) }\end{array}$ \\
\hline JAMS Class Action Procedures & $\begin{array}{l}<\text { http://www.jamsadr.com/rules-class- } \\
\text { action-procedures/> accessed } 4 \text { July } 2014\end{array}$ \\
\hline
\end{tabular}




\begin{tabular}{|c|c|}
\hline $\begin{array}{l}\text { Regulation of the Câmara de } \\
\text { Arbitragem do Mercado }\end{array}$ & $\begin{array}{l}\text { <www.bmfbovespa.com.br/pt- } \\
\text { br/download/nova-regulamentacao.pdf> } \\
\text { accessed } 4 \text { July } 2014\end{array}$ \\
\hline $\begin{array}{l}\text { Regulation of the Loss Recovery } \\
\text { Mechanism [LRM] }\end{array}$ & $\begin{array}{l}<w w w . b s m- \\
\text { autorregulacao.com.br/instdownload/novo- } \\
\text { regulamentomrp.pdf> accessed } 04 \text { July } 2014\end{array}$ \\
\hline $\begin{array}{l}\text { Restatement (Second) of Conflict of } \\
\text { Laws }\end{array}$ & $\begin{array}{l}\text { Restatement Second, Conflict of Laws } \\
\text { (American Law Institute) }\end{array}$ \\
\hline $\begin{array}{l}\text { Uncitral Model Law on International } \\
\text { Commercial Arbitration (2006) }\end{array}$ & $\begin{array}{l}\text { Uncitral Model Law on International } \\
\text { Commercial Arbitration (1985), with } \\
\text { amendments as adopted in } 2006\end{array}$ \\
\hline $\begin{array}{l}\text { Uniform Foreign Money- } \\
\text { Judgments Recognition Act }\end{array}$ & $\begin{array}{l}\text { Uniform Law Commission, Uniform Foreign } \\
\text { Money-Judgments Recognition Act (1962) } \\
\text { <www.uniformlaws.org> }\end{array}$ \\
\hline
\end{tabular}

\section{Spain}

Law 11/2011

Ley $11 / 2011$, de 20 de mayo, de reforma de la Ley 60/2003, de 23 de diciembre, de Arbitraje y de regulación del arbitraje institucional en la Administración General del Estado [2011] BOE-A-2011-50797

Law 19/1988 [Financial Audit Law] Ley 19/1988, de 12 de julio, de Auditoría de Cuentas [1988] BOE-A-1988-17704

Law 24/1988 Ley $24 / 1988$, de 28 de julio, del Mercado de Valores [1988] BOE-A-1988-18764 


\begin{tabular}{l|l} 
Law 3/1991 & $\begin{array}{l}\text { Ley 3/1991, de } 10 \text { de enero, de Competencia } \\
\text { Desleal [1991] BOE-A-1991-628 }\end{array}$ \\
\hline Law 34/1988 & $\begin{array}{l}\text { Ley 34/1988, de } 11 \text { de noviembre, General } \\
\text { de Publicidad [1988] BOE-A-1988-26156 }\end{array}$ \\
\hline $\begin{array}{l}\text { Law 60/2003 [Spanish Arbitration } \\
\text { Law 7/1998 }\end{array}$ & $\begin{array}{l}\text { Ley 60/2003, de 23 de diciembre, de } \\
\text { Arbitraje [2003] BOE-A-2003-23646 }\end{array}$ \\
\hline Ley 7/1998, de 13 de abril, sobre condiciones \\
generales de la contratación [1998] BOE-A- \\
$1998-8789$
\end{tabular}

\begin{tabular}{l|l} 
UK \\
\hline Civil Procedure Rules & Civil Procedure Rules \\
\hline Consumer Credit Act 2000 & Consumer Credit Act 2000 \\
\hline FCA Handbook & FCA Handbook \\
\hline $\begin{array}{l}\text { Financial Services and Markets Act } \\
2000\end{array}$ & Financial Services and Markets Act 2000 \\
\hline
\end{tabular}




\begin{tabular}{|c|c|}
\hline Class Action Fairness Act [CAFA] & Pub. L. No. 109-2, 119 Stat 4 (2005) \\
\hline $\begin{array}{l}\text { Dodd-Frank Wall Street Reform } \\
\text { and Consumer Protection Act } \\
\text { (2010) [Dodd-Frank Act] }\end{array}$ & Pub. L. No. 111-203, 124 Stat. 1376 (2010) \\
\hline Federal Arbitration Act & $\begin{array}{l}\text { Pub.L. } 68-401,43 \text { Stat. } 883 \text { (1925) (current } \\
\text { version at } 28 \text { U.S.C. } \$ 1(2014) \text { ) }\end{array}$ \\
\hline Federal Rules of Civil Procedure & Federal Rules of Civil Procedure \\
\hline Investment Advisers Act of 1940 & (current version at 15 U.S.C. $\S 80 a-1(2014)$ ) \\
\hline $\begin{array}{l}\text { Private Securities Litigation Reform } \\
\text { Act [PSLRA] }\end{array}$ & $\begin{array}{l}\text { Private Securities Litigation Reform Act of } \\
\text { 1995, Pub. L. 104-67, } 109 \text { Stat. } 737 \text { (1995) }\end{array}$ \\
\hline Regulation D & 17 C.F.R. $\S \S 230.501$ - 230.506 (2012) \\
\hline Regulation S & 17 C.F.R. § $200.901-\S 200.905$ (1998) \\
\hline Regulation S & 17 C.F.R. §§ 230.901-230.905 (2013) \\
\hline Regulation S-K & 17 C.F.R. § 229 (2013) \\
\hline Rule $10 b-5$ & 17 C.F.R. § 240.10b-5 (2013) \\
\hline Rule 144 & 17 C.F.R. $\S 230.144$ (2012) \\
\hline Rule 144A & 17 C.F.R. $\S 230.144 a(2013)$ \\
\hline Rules Enabling Act & $\begin{array}{l}\text { Pub. L. No. } 73-415 \text {, } 48 \text { Stat. } 1064 \text { (1934) } \\
\text { (current version at } 28 \text { U.S.C. } \S 2072 \\
(2014) \text { ) }\end{array}$ \\
\hline $\begin{array}{l}\text { Sarbanes-Oxley Act of } 2002 \\
\text { [Sarbanes-Oxley Act] }\end{array}$ & Pub. L. No. 107-204, 116 Stat. 745 (2002) \\
\hline
\end{tabular}




\begin{tabular}{l|l} 
Securities Act of 1933 & $\begin{array}{l}\text { Pub. L. No. 73-22, 48 Stat. 74 (1933) } \\
\text { (current version at 15 U.S.C. § 77a (2014)) }\end{array}$ \\
\hline $\begin{array}{l}\text { Securities Exchange Act of 1934 } \\
\text { Pub. L. No. 73-291, 48 Stat. } 881 \text { (1934) } \\
\text { (current version at 15 U.S.C. § 78a (2014)). }\end{array}$ \\
$\begin{array}{l}\text { Securities Litigation Uniform } \\
\text { Standards Act [SLUSA] }\end{array}$ & Pub. L. No. 105-353, 112 Stat. 3227 (1998) \\
\hline \begin{tabular}{l} 
U.S. Constitution \\
\hline
\end{tabular} & U.S. Constitution \\
\hline
\end{tabular}

\section{Treaties and other International Instruments}

\begin{tabular}{|c|c|}
\hline Brussels Convention & $\begin{array}{l}\text { Convention on jurisdiction and the } \\
\text { enforcement of judgments in civil and } \\
\text { commercial matters (adopted } 27 \text { September } \\
\text { 1968) }\end{array}$ \\
\hline Dispute Resolution Understanding & $\begin{array}{l}\text { Understanding on Rules and Procedures } \\
\text { Governing the Settlement of Disputes, WTO } \\
\text { Agreement Annex II. }\end{array}$ \\
\hline $\begin{array}{l}\text { Geneva Convention for the } \\
\text { Execution of Foreign Arbitral Awards }\end{array}$ & $\begin{array}{l}\text { Convention on the Execution of Foreign } \\
\text { Arbitral Awards (adopted } 26 \text { September } \\
\text { 1927, entered into force } 25 \text { July 1929) } 92 \\
\text { LNTS } 301\end{array}$ \\
\hline $\begin{array}{l}\text { Geneva Protocol on Arbitration } \\
\text { Clauses }\end{array}$ & $\begin{array}{l}\text { Protocol on Arbitration Clauses (adopted } 24 \\
\text { September 1923, entered into force } 28 \text { July } \\
\text { 1924) } 27 \text { LNTS } 158\end{array}$ \\
\hline Hague Service Convention of 1965 & $\begin{array}{l}\text { Convention of } 15 \text { November } 1965 \text { on the } \\
\text { Service Abroad of Judicial and Extrajudicial } \\
\text { Documents in Civil or Commercial Matters }\end{array}$ \\
\hline
\end{tabular}




\begin{tabular}{|c|c|}
\hline & $\begin{array}{l}\text { (adopted } 15 \text { November 1965, entered into } \\
\text { force } 10 \text { February 1969) }\end{array}$ \\
\hline ICJ Statute & Statute of the International Court of Justice \\
\hline ICSID Convention & $\begin{array}{l}\text { Convention on the Settlement of Investment } \\
\text { Disputes Between States and Nationals of } \\
\text { Other States (adopted } 18 \text { March 1965, } \\
\text { entered into force } 14 \text { October 1944) }\end{array}$ \\
\hline New York Convention & $\begin{array}{l}\text { Convention on the Recognition and } \\
\text { Enforcement of Foreign Arbitral Awards } \\
\text { (adopted } 10 \text { June 1958, entered into force } 7 \\
\text { June 1959) } 330 \text { UNTS } 3\end{array}$ \\
\hline Treaty of Amsterdam 1997 & $\begin{array}{l}\text { The Treaty of Amsterdam amending the } \\
\text { Treaty on European Union, the Treaties } \\
\text { establishing the European Communities and } \\
\text { certain related acts (adopted } 2 \text { October } \\
\text { 1997) }\end{array}$ \\
\hline $\begin{array}{l}\text { Universal Declaration of Human } \\
\text { Rights }\end{array}$ & $\begin{array}{l}\text { Universal Declaration of Human Rights } \\
\text { (adopted } 10 \text { December 1948) UNGA Res } 217 \\
\text { A(III) (UDHR) }\end{array}$ \\
\hline WTO Agreement & $\begin{array}{l}\text { Agreement Establishing the World Trade } \\
\text { Organization (15 April 1994) }\end{array}$ \\
\hline
\end{tabular}





\section{Part I - Introduction}

As financial markets are legal constructs, ${ }^{1}$ the Rule of Law is essential to their proper functioning. The argument of this thesis is that a transnational legal infrastructure for transnational securities transactions is still lacking, undermining the creation of stronger transnational financial markets. This work attempts to propose an infrastructure that improves securities dispute resolution transnationally.

The thesis is divided into 3 parts. The introduction is found in Part I. Chapter I sets out the research problem, the research question and the limitations of the study. Chapter II establishes the theoretical framework that the work is based upon by analyzing the development of the modern state, the economic importance of a legal system based on the Rule of Law, the role of regulatory law and the role of dispute resolution mechanisms.

The underlying theme of Part II is securities regulation. The objective of this part is twofold: 1) to justify the purpose of securities regulation, since the rest of the thesis is premised on the fact that securities regulation is important to address market failures, benefiting capital markets and 2) to identify the types of disputes that arise out of securities transactions. Chapter III provides the historical background of the development of securities regulation, which shows that the regulatory character of securities law is related to real-life market failures. Chapter IV reviews the literature on securities regulation and theoretically justifies its importance, as well as the role that private enforcement plays. Chapter $\mathrm{V}$ describes and explains the securities issuance process and identifies the different types of disputes that may arise, providing the basis for the development of the last part of the thesis.

Part III is concerned with dispute resolution. Chapter VI explores the institutional aspects that are important to efficient dispute resolution systems and which allow for the Rule of Law to operate. Chapter VII surveys some different models of dispute resolution mechanisms that can serve as a basis for the design of a system tailored to securities transactions. Chapter VIII discusses aggregate litigation to find a solution to the question

\footnotetext{
${ }^{1}$ Katharina Pistor, 'A Legal Theory of Finance' (2013) Columbia Public Law Research Paper No 13-348.
} 
of access, exploring the institutional incentives and the legal aspects of the mechanism; some examples are provided in Chapter IX. Chapter X explores the problems that arise in the transnational context, examined via the analysis of private international law doctrines and their shortcomings for securities transactions. Finally, Chapter XI proposes some avenues for reform. 


\section{Chapter I - The Research Problem, Questions and Limitations of the Study}

"[C]ross-border problems call for cross-border solutions"2

This $\mathrm{PhD}$ thesis explores the dispute resolution systems for securities transactions in a transnational environment. Its objective is to identify the problems of transnational securities disputes and to propose a solution to improve the legal infrastructure that deals with them.

Globalization results in a higher number of cross-border financial transactions, many of which involve securities transactions, which are regulated predominantly at the local level. While the flows of capital are becoming more and more global, the markets, from a legal perspective, are highly local, as are the regulatory systems and dispute resolution mechanisms available to investors. This situation may pose serious problems, especially to small and medium-sized investors, who may not be able to seek legal relief due to transaction cost constraints in pursuing a lawsuit against an entity in which it has made an investment. The problem becomes even more acute in an environment in which, notwithstanding the existence of multiple jurisdictions, there are political and legal processes in development which aim to facilitate a common internal market, such as the European Union, as it functions as a barrier to market development. Solving this problem would open up the scope for a higher degree of transnational financial transactions as a wider pool of capital would be available for investment, enhancing the benefits of the free flow of capital ${ }^{3}$ and guaranteeing that the investor's rights would be protected.

\section{The Research Problem}

The world is a different place than it was 100 years ago. Technology has changed it completely, generating greater interconnectivity than ever before; financial transactions

\footnotetext{
2 Tom Bingham, The Rule of Law (Allen Lane 2010) 115.

3 For the benefits and risks of an increased flow of capital, see International Monetary Fund, 'The Liberalization and Management of Capital Flows: an Institutional View' (2012), 10-14.
} 
are not an exception. Two recent financial transactions with dire consequences to their investors can illustrate this point:

1) Paulson \& Co., a New York based hedge fund, requested that Goldman Sachs structure a synthetic financial product based on Residential Mortgage Backed Securities ${ }^{4}$ to be sold to qualified institutional buyers under SEC Rule $144 \mathrm{~A}^{5}$ and to foreigners outside the US under SEC Regulation S. ${ }^{6}$ Thereafter two different legal entities, one based in the Cayman Islands ${ }^{7}$ and another based in the State of Delaware in the United States were set up as Special Purpose Vehicles to issue the securities. To increase the marketability of the securities, ACA Management LLC, a portfolio selection agent, was chosen to select the underlying mortgages. During the selection process, Paulson \& Co. helped ACA Management, but the hedge fund had - since the beginning - been betting against the residential mortgage market without disclosing such information. The deal was closed on April 26, 2007, the securities were sold, including to foreign investors, ${ }^{8}$ and by January 29,2008 , those investors had already lost more than $\$ 1$ billion dollars on the product, while the hedge fund that helped to choose the underlying mortgages was profiting by a figure of around the same amount, i.e. $\$ 1$ billion dollars. ${ }^{9}$

2) In another case, National Australia Bank, an Australian bank with shares not traded on an American exchange, but traded on various foreign exchanges and also having ADRs traded on an US exchange, purchased HomeSide Lending, a company headquartered in Florida that was in the business of servicing mortgages. The purchase was made in 1998, and until 2001 National's annual reports touted the success of HomeSide. ${ }^{10}$ On 5 July 2001, National Australia Bank wrote down HomeSide Lending assets by $\$ 450$ million and did the same again on

\footnotetext{
4 This product is the ABACUS 2007-AC1 created by Goldman Sachs.

517 C.F.R. $§ 200.144 a$ (1992).

617 C.F.R. $§ 200.901-\S 200.905$ (1998).

${ }^{7}$ Abacus 2007-AC1 Indicative terms.

8 E.g., IKB Deutsche Industriebank AG.

${ }^{9}$ See Complaint, SEC v Goldman Sachs and Fabrice Tourre, WL 2305988 (S.D.N.Y. 2011).

10 Morrison v National Australia Bank, 561 U.S. 247, 251 (2010).
} 
September 3 , this time by $\$ 1.75$ billion, heavily impacting a multitude of Australian and other non-U.S. investors.

The transnationality of these transactions is evident. Capital flows across borders and parties engage in commercial relationships that are anchored in many different legal systems. Globalization brings many advantages but it also poses serious risks, especially when it comes to finance. ${ }^{11}$ As the pace of globalization increases, the number of financial transactions with a transnational character also tends to increase, posing serious legal problems to the existing state-based legal framework. ${ }^{12}$

The problem is one of a plurality of legal systems governing the same transactional scheme without any consistent mechanism of coordination. The Rule of Law and different legal concepts of national legal systems, which are essential to the successful functioning of markets, become increasingly difficult to manage when they are tied to different sources of legal authority that apply either to the specific parts of the transaction or to the transaction as a whole, often failing or being insufficient to address market failures that are essential to the development of healthy markets.

Law, when applied to commercial and financial transactions, provides a background in which transactions can be made and disputes can be peacefully solved in cases of disagreement between the parties. It provides a level of certainty that allows parties to engage in transactions and to avoid the necessity of the private deployment of force. Trust solely in the counterparty is substituted, at least in part, for the trust in the legal system. A businessman living in an imaginary country with a robust legal system can invest in a company without having to worry if the information provided to him is true; if he has been misled he can summon his lawyer and recover the money that has been lost in the transaction. Even though the lawyer will be compensated, the legal system is designed in such a way to avoid high costs being imposed on the party who needs redress, even for a relatively small-sum lawsuit.

${ }^{11} \mathrm{Hal}$ S. Scott, International Finance: transactions, policy, and regulation (Foundation Press 2010) 20-22.

${ }^{12}$ Randall Kroszner claims that 'many international financial transactions occur in a realm that is close to anarchy', see Randall Kroszner, 'The Role of Private Regulation in Maintaining Global Financial Stability' (1999) 18 Cato Journal 355, 355. 
Now bring the same businessman to the real world and place him in the United States, a country considered to have a robust legal system and strong securities regulation. Make him invest in China. The businessman may invest in a Chinese company but if that company's shares lose value because of fraudulent information, the investor may be left penniless, even though the whole strength of the U.S. Securities Regulation system may be at his side, simply because the Chinese company has its assets in China. ${ }^{13}$

Transnational disputes give rise to additional questions than transactions that are merely national: Where can the dispute be entertained? Which law is applicable? Where and how is this decision enforceable? These questions increase the complexity of the factors that have to be weighed in deciding whether to invest abroad; the decision will depend on how developed the legal infrastructures are of the place in which the transaction is anchored. When it comes to finance, another wrinkle emerges in conceptualizing the problem: many of the transactions involve the use of securities, which are heavily regulated by national states. National mandatory law defines what securities are, the duties of the issuer and the range of action that brokers and market players are afforded when transacting these instruments, even though these transactions, considering the bigger picture, are often in fact transnational.

The transnational character, embedded in the legal pluralism that is inherent in transactions occurring across borders, increases the complexity of the legal problems at stake. Due to the size of many transnational securities transactions and the amount of trading that is done, there is a lot at stake. ${ }^{14}$ The health of financial markets is tied to the

${ }^{13}$ Cultural, language and legal barriers raise the costs of pursuing litigation in a case like this, since either the case is pursued in the United States and the judgment has to be enforced in China or the whole case has to be litigated in China. The small settlement amounts that have been reached in securities cases with Chinese companies listed in the U.S. are indicative of these possible hurdles. See Kevin LaCroix, "The Modest Early Settlements of Securities Suits Involving U.S.-Listed Chinese Companies' (The D\&O Diary, 22 June 22) <http://www.dandodiary.com/2012/06/articles/securities-litigation/the-modest-early-settlements-ofsecurities-suits-involving-u-s-listed-chinese-companies/> accessed 07 July 2014.

14 There is an increase in the number of securities transactions in the past years. The United States and Brazil can be seen as good examples of the increase of foreign positions on securities. In the United States there was an expressive increase of foreign private securities assets in the last 40 years, from US\$44,157 million in 1976 to US\$6,222,864 million in 2010. Brazil also had an increase; on December 2001 Brazil's international position regarding foreign securities assets was of US\$6,402 million and 11 years later the amount increased to US\$25,759 million. In Spain the increase in foreign positions in private securities investments was not so impressive; it went from € 78,053 million in 2004 to € 89,494 million in 2012. Before the crisis, Spain reached $€ 132,954$ million in foreign securities assets, but evidenced a strong decrease following it. Nonetheless, the foreign position in securities remains substantial and it has been recovering. See Banco Central do Brasil, 'Série Histórica da Posição Internacional de Investimento' 
legal and technological infrastructures underpinning them, and a decision of a national court can completely change expectations, sometimes putting at stake billions of dollars that are based on transactions similar to the one on the basis of which the decision was made. ${ }^{15}$

At a more individual level, the question arises as to what extent investors are able to rely on the legal infrastructure in place. The free flow of capital is good for economic efficiency, but the aperture of the system can also bring fraudsters to the market; these fraudsters can harm investors in places far away from where they actually operate. A robust transnational legal system for dispute resolution could ease these concerns, as it would allow investors to obtain redress.

The existence of multiple legal orders to which a single economic transaction can be attached is a legal risk that can become problematic to the development of global securities markets. Legal instability due to the competing sources of norm creation, decision-making and enforcement mechanisms affects the predictability of results, which in turn affect the costs of doing business. The development of complementary mechanisms of dispute resolution and coordination among different legal systems can be a valuable instrument to improve the costs of transacting in a globalized world.

<http://www.bcb.gov.br/?SERIEPIIH> accessed 07 July 2014; Bureau of Economic Analysis, ' International Investment Position of the United States at Yearend, 1976-2010' <http://www.bea.gov/international/xls/intinv10_t2.xls> accessed 07 July 2014; Banco de España, Boletín Estadístico 12/2012 (2013).

${ }^{15}$ An interesting example are two cases involving the same transaction in the Lehman Brothers bankruptcy: Lehman Brothers v. BNY Corporate Trustee, 422 B.R. 407 (S.D.N.Y. 2010) and Belmont Park Investments v. BNY Corporate Trustee, [2011] UKSC 38. The transaction in these two cases was composed by a series of credit swap transactions through the use of various SPVs incorporated in jurisdictions chosen for tax purposes. In the specific transaction under consideration involving the SPV Saphir Finance plc, which was incorporated in Ireland, English Law was chosen. The SPV had a credit default swap with Lehman Brothers Special Financing. The transaction was collateralized, and the Trustee for the collateral was BNY Corporate Trustee Services Ltd. There was a provision in the transaction documents that the priority of the collateral would shift in case there was an Event of Default by Lehman Brothers Special Financing, which occurred when Lehman Brothers Special Financing went bankrupt. Even though there was an expectation of the parties ex ante that this was a possible transaction, the US decision in 2010 signaled otherwise, creating an uncertain environment for all similar transactions where the CDS counterparty is American. Later, the English Supreme Court confirmed that the transaction was valid under English Law. The American case settled in 2010, without a decision of a higher court, and new litigation on the same subject has started again. See Tracy Alloway, 'The Lehman flip-clause flap gets settled - sort of' (FT Alphaville, 27 July 2011) <http://ftalphaville.ft.com/2011/07/27/634976/the-lehman-flip-clause-flap-gets-settled-sort-of/> accessed 7 July 2014. 


\section{The Research Question}

The instability of legal relations arising from the tension of the transnational being regulated nationally is the starting point of this research. While capital mobility is deemed to be easier today than it was 100 years ago, be it due to the increasing interlinkage among the different corners of the world or the technological developments that have been made in the last decades, moving capital and goods across borders is not yet as easy as moving them within a country. Notwithstanding claims as to the loss of power of the nation-state, its power still is substantial in regulating economic activity under its area of influence. ${ }^{16}$ There is no vacuum; the nation-state is still present with its entire institutional framework remaining relevant to every aspect of everyday business life, either exercising power through direct regulation or constituting the background environment for business. ${ }^{17}$

The role of the legal system in the operation of a market is threefold - firstly, it provides the background framework so economic transactions can be entered into; secondly, it regulates behavior that should not be allowed due to the negative effects that it may cause and finally, it provides avenues for redress for those who have been harmed by a party that does not comply with what has been promised or who does not behave according to the rules of the market.

In contract law, an example of the first role of the legal system is the following: if $A$ offers B to sell his car for US $\$ 10,000$ and B accepts, a contract is formed. In case A decides to back out of the transaction, B can pursue A in a court of law to recover damages. ${ }^{18}$ In the securities area, the example of the second role and third role of the legal system is the

\footnotetext{
${ }^{16}$ For a discussion of the nation-state in a globalized era, see Vincent Cable, "The Diminished Nation-State: a Study in the Loss of Economic Power' (1995) 124 Daedalus 23.

${ }^{17}$ It is true that illegal activities fall outside of the direct control of the state, but this is not the focus of this work. In every other activity the state is deeply present. Think about a business that is within legality and all the necessary permits and taxes that it has to pay. The entrepreneur can avoid a nation state, but if he wants to operate within legality, he will unavoidably fall within the domain of another nation-state. Contracting around one nation state is possible, but this means not doing business in it and invariably one state or another will oversee business.

${ }^{18}$ Specific performance is not the usual method for compensation in the United States. See John Calamari and Joseph Perillo, The Law of Contracts (4th edn, West Group 1998) 611-13.
} 
following: if A is obliged to disclose information and fails to do so, A will be liable to B for the loss of value in stock when the information is subsequently discovered.

The framework of a given legal system affects the way in which people behave. This is true not only in respect of the identification of the substantive rules and the expected outcome given the occurrence of a legal fact, but also with regard to the costs of engaging the state in the dispute, by solving it and enforcing the outcome. In each legal system the architecture is defined by policy choices that have been made throughout history, creating different substantive rules and enforcement mechanisms depending on the jurisdiction that is analyzed. These are aspects that have to be taken into consideration. It is clear that given a breach of a legal rule by $\mathrm{A}$ in a country where the legal system is effective, it is less likely that B will need other guarantees for the transaction since the legal system will be available to solve the problem. In the case that the legal infrastructure is weak, for example with high costs for litigation and trials that are too long, A would use other instruments, such as demanding collateral in an escrow account or the guarantee of a trustworthy person, before engaging in a transaction with B. This is important for the development of a local financial market, as high legal costs and uncertainty as to the rules operating at a given time, or the enforcement of those rules, may discourage investment.

The transnational aspect raises the significance attached to the considerations that have to be taken into account. In this environment, no longer is there only one legal system that has to be considered, but rather, as many different jurisdictions as the number that may be involved in the transaction must be examined. The BNY case cited above involved Australian investors purchasing securities from an Australian SPV that purchased securities from an Irish SPV, which in turn had a swap transaction governed by English Law with an American company, with England being the chosen forum for any disputes. There were at least four different jurisdictions involved in this single case.

The legal uncertainty arising from this scenario undermines the safety that law can provide to securities transactions. The problem of legal uncertainty is even stronger in 
this field, as finance is a legal construction. ${ }^{19}$ Legal uncertainties create risk, but the fewer legal risks that are present, the better it is for the parties to engage in transactions. ${ }^{20}$

The answer to any question arising out of these considerations has to include both the national and the international legal framework, substantively and procedurally. Depending on the legal question being decided, the answers can differ widely across different jurisdictions, even if the substantive rules of behavior are similar. In addition, even if the rules were the same, the enforcement of a decision from one jurisdiction is not always enforceable in a second one, where the assets of the person liable for the harm caused to the investor may be located. This is due to the public policy aspect of securities regulation, and more generally financial regulation, especially in the so-called public markets, where the general population can purchase securities. Business and investment decisions are, consciously or not, embedded in this social reality.

The stability of the legal infrastructure upon which a transnational transaction is anchored matters because it allows for the enforceability of the parties' rights when duties are breached, being related to the costs of doing business. As the legal structures in place to address these concerns are far from being perfect, this research will be guided by the following research question:

'How can the legal infrastructure for transnational securities transactions disputes be improved?'

The answer to the research question lies in the assessment of the problems currently present in the transnational framework for dispute resolution in securities disputes. The underlying goal of the research is to provide options to strengthen the procedural efficiency of the legal framework that can be used to solve transnational securities disputes, consequently enhancing investor protection to serve as the background for the development of a more robust global financial market.

Notwithstanding that all countries do indeed have securities regulation and are interested in investor protection, the level of protection is a matter of public policy, which 
can be a barrier to the effective transnationalization of securities transactions, or at least to the enforcement of decisions related to them. Therefore, to be able to properly answer the first question, a second question must also guide the research:

'To what extent do public policy considerations of securities transactions influence private (national and international) law?'

In order to answer these questions, the work proceeds in the following way: firstly, I establish the purpose of and importance of securities regulation and the policy choices behind it; secondly, I analyze the private liability regimes arising out of securities regulation in order to define the scope of disputes that are relevant in this field; thirdly, I provide a framework to analyze the important aspects of a dispute resolution system and survey certain frameworks that can be used in securities disputes; finally, I analyze the private international law regime and the legal problems arising therefrom, related to securities disputes. This provides a sufficient background in order to pose an answer to the main research question.

\section{Thesis and Outline of the Argument}

The thesis proposes the following: 'considering that private enforcement is a crucial mechanism for the application of securities laws, investor protection and the construction of efficient capital markets, a more stable system of dispute resolution for transnational securities transactions is necessary for a better functioning of the transnational securities market.'

The main claims that I make throughout the next chapters can be briefly summarized as follows:

1. As capital markets are legal constructs, the Rule of Law is necessary for their development (Chapters 2 and 4);

2. The role of law for capital markets is twofold: a. to provide protection for property and to enforce promises; b. to regulate market failures in order to protect investors and avoid the 'lemons problem' (Chapters 2 and 4);

3. These two goals run together: the regulatory aspect creates expectations; the breach of these expectations are better addressed through private 
rights of action as a starting point, both from an economic as well as a social point of view (Chapter 4);

4. Therefore, the enforcement of these expectations becomes a problem of access to justice, where the investor needs to be able to enforce both the rights arising out of the security itself as well as the rights related to the regulatory background within which the transaction was embedded (Chapters6, 7, 8 and 9);

5. The adequacy of a dispute resolution method for securities transactions depends on the type of dispute at stake, since their specific characteristics may warrant different types of schemes (Chapter 5);

6. Collective redress is adequate for disputes involving a multitude of claimants based on the same underlying facts, but not for transactions made with financial intermediaries (Chapters 6, 7, 8 and 9);

7. At the transnational level, the transnational infrastructure of private law enforcement does not yet provide a proper solution for the problem, as the rules of private international law remain too uncertain to be relied upon due to the underdevelopment of its rules concerning securities transactions and due to public policy considerations. (Chapter 10).

Based on these claims and the analysis undertaken throughout the rest of this work, which shows that there is no one size fits all solution, I then propose two mechanisms to increase legal certainty and to provide better access/protection to investors in transnational securities transactions.

\section{Scope and Limitations of the Study}

The volume of literature on transnational litigation and securities regulation is quite dense, but the discussion of transnational securities litigation still is in its infancy. While a few studies have already been undertaken, a systematic understanding of the problems involved in these kinds of disputes is still lacking.

The importance of the study is based on the use of securities as a method of financing the most varied types of economic activities. The process allows corporations to raise equity or to issue debt in order to pursue its business as well as to structure different 
investment vehicles through the securitization process, ${ }^{21}$ which is backed by the legal system in creating duties and liabilities on the part of the parties involved. The breach of a duty is corrected through litigation or another form of dispute resolution, either public or private. ${ }^{22}$ Both types of enforcement form part of the regulatory architecture, but the private one plays a crucial role in stabilizing the expectations of the parties in a securities transaction and providing confidence for engaging therein, contributing to the integrity of a securities market.

As the legal systems involved in securities regulation and the disputes in this area of law are grounded in state structures, the research is comparative in nature, which imposes a limitation on the current work. The main focus of the thesis is on the U.S., EU and Brazil, however some consideration will be given to important developments occurring in other jurisdictions. The choices have been made on the basis of determinations pertaining to relevance and practicality.

The United States is the crib of securities regulation and securities disputes; discussing transnational securities dispute resolution without discussing the American literature would lead to a failure to grasp some important questions in this area. The EU was chosen due to its internal transnational aspect and its federalist structure, which is interesting both from a securities regulation perspective and in light of the legal infrastructure for transnational dispute resolution. Finally, with its growing importance in the international arena and being a country of interest for the author, Brazil was the third jurisdiction chosen for this study. Moreover, the different aspects of the dispute resolution structure and the practice involving securities litigation in these countries were deemed relevant to this decision. The United States has a predominantly dual structure, with the possibility of class actions against issuers and a highly institutionalized arbitration method against broker-dealers; The EU has seen some litigation against financial intermediaries, particularly following the demise of Lehman Brothers,

\footnotetext{
${ }^{21}$ For an overview of the securitization process, see David Ramos Muñoz, The Law of Transnational Securitization (Oxford University Press 2010).

22 Public litigation in this work is understood as litigation initiated by governmental bodies, such as Securities and Exchange Commissions or Public Attorney's Offices, while private litigation is considered the one initiated by a party due to its capacity as an investor, or as an investor's representative, be the litigant a private party or a State.
} 
generating a good source of material to analyze dispute resolution in practice, while at the same time bringing to the fore relevant legislation as well as interesting mechanisms underpinning the creation of alternative methods of dispute resolution in this area. Finally, Brazil presents an obscure arbitration system that is mandatory to the corporations listed within the two higher corporate governance levels in the Brazilian stock exchange; at the same time there is almost no court litigation on securities matters, despite specific legislation for aggregate litigation in this area.

The peculiarities of these systems provide ample material for the analysis of the problems in dispute resolution systems for securities transactions, giving foundation to a deeper reflection on how to improve the transnational infrastructure for dispute resolution in securities transactions. 


\section{Chapter II - States, Law and Dispute Resolution}

The overarching problem that this thesis tries to address is one of economic transactions being grounded in different legal structures and how disputes arising out of these transactions are solved. Legality is dependent on legal systems, which are in turn dependent on socio-political structures. The question underpinning this chapter is: 'What is the relationship between states, law and dispute resolution?'

Legal systems have arisen out of the interaction between men and their political organizations in states or state-like structures. States rise from human interaction. As long as there is a group of men engaging in everyday activities amongst themselves for an extended period of time, states are bound to appear. Historically they exist at least as far back as the first agricultural societies, 10.000 years ago in Mesopotamia. ${ }^{23}$ In the Weberian sense of the term, the 'state' can be defined as 'a human community that (successfully) claims the monopoly of the legitimate use of physical force within a given territory', ${ }^{24}$ which means that the state's essence is nothing more than power of enforcement. ${ }^{25}$ More specifically, the state can be defined in the following manner:

A compulsory political organization with continuous operations (politischer Anstaltsbetrieb) will be called a 'state' insofar as its administrative staff successfully upholds the claim to the monopoly of the legitimate use of physical force in the enforcement of its order. ${ }^{26}$

This essence of the state underpins the whole judicial structure and its effective use by private parties via litigation - and consequently securities litigation. As securities transactions become increasingly globalized, different states and their legal structures will be increasingly involved in sorting disputes that may arise out of them. The analysis of the possible interactions of different legal systems in dispute resolution must begin

\footnotetext{
${ }^{23}$ Francis Fukuyama, State-Building: Governance and World Order in the 21st Century (Cornell University Press 2004) 1.

${ }^{24}$ Max Weber, From Max Weber: Essays in Sociology (Routledge 1991) 78.

25 Fukuyama 6 (n 23).

${ }^{26}$ Max Weber, Economy and Society (University of California Press 1978) 54.
} 
with the understanding of the bases of legal systems and their role in regulating private relationships. This is the objective of this chapter.

\section{The Development of the Modern State}

The modern state has the following basic characteristics:

[...]It possesses an administrative and legal order subject to change by legislation, to which the organized activities of the administrative staff, which are also controlled by regulations, are oriented. This system of order claims binding authority, not only over the members of the state, [...] but also to a very large extent over all action taking place in the area of its jurisdiction. [...] Furthermore, today, the use of force is regarded as legitimate only so far as it is either permitted by the state or prescribed by it. ${ }^{27}$

The formation of the modern state has come a long way, and there are different theories as to how the state, as a political entity, has come into existence. A convincing one is based on ecological factors of particular regions of the world ${ }^{28}$ and its consequence in the organization of social groups. ${ }^{29}$ As far as the ecological theory goes, there are three factors that were relevant to the rise of the state: ${ }^{30}$ environmental circumscription, resource concentration and social circumscription.

The theory begins with small autonomous farming communities that did not interact with each other, but were bound territorially by environmental characteristics, such as mountains, valleys and rivers. ${ }^{31}$ With the growth of these farming communities, not only in size but also in quantity through the creation of new distinct ones, the available land for farming was soon depleted and the human pressure on the land began to increase, leading to physical disputes between the villages. ${ }^{32}$ Since they were circumscribed

\footnotetext{
27 Ibid 56.

${ }^{28}$ Robert L. Carneiro, 'A Theory of the Origin of the State: Traditional Theories of State Origins are Considered and Rejected in Favor of a New Ecological Hypothesis' in John A. Hall (ed), The State: Critical Concepts, vol I (Routlegde 1994).

${ }^{29}$ This theory will be used to illustrate the initial evolution of the state until its current model.

30 The author defines state as 'an autonomous political unit, encompassing many communities within its territory and having a centralized government with the power to collect taxes, draft men for work or war, and decree and enforce laws' Carneiro 433 (n 28).

${ }^{31}$ The example used in the text was the Peruvian coastal valley. Ibid 437.

32 Ibid 437-38.
} 
territorially, those who lost could not flee, and to be able to stay on the land they became subordinated to the winners and obliged to pay taxes. This also involved the loss of political autonomy on the part of those who were defeated, as they were incorporated into the political unit of the winner. ${ }^{33}$ The process would repeat itself, transforming villages into chiefdoms and chiefdoms into kingdoms. Meanwhile, internally, these newlyformed kingdoms had to administer those new areas as they were conquered, leading to social divisions, through the empowerment of the persons loyal to the winning side of those disputes (the upper class) and the employment of the losers as servants and slaves (the lower class). ${ }^{34}$ Finally, those who were made landless but not enslaved tended to go to the towns and cities that were spawning at the time, earning a living through working for the upper class, financed by the surplus taken from village farmers. ${ }^{35}$

The resource concentration and the social circumscription facets of the ecological theory of state creation explain the exceptions of the environmental circumscription factor: states were created not only on the basis of circumscribed agricultural land, but also from more open areas. A small area with a high concentration of resources would play a similar concentrating role as environmental barriers, leading to a concentration of different autonomous groups of people that would end up fighting for these resources, and ultimately generating the same processes of warfare and political integration. ${ }^{36}$ Finally, another factor that may have played a role in political integration in the first days of state formation in the history of mankind may have been social circumscription. Research on the Yanomamo Indians of Venezuela shows that villages that were surrounded by other villages tended to be larger, possibly due to the higher probability of warfare with neighboring villages and the consequent political integration resulting therefrom, due to the fact that the villages in the center of an area might have been more prone to attacks and outside influence than those at the periphery. ${ }^{37}$ If this theory is correct, the initial formation of states is due to the consolidation and systematization of

\footnotetext{
33 Ibid 439.

34 Ibid.

35 Ibid.

36 Ibid 440-41.

37 Ibid 441-43.
} 
the exercise of power through a delimited geographical space, confirming Weber's definition of statehood.

As previously mentioned, the definition of state comprises a claim of the monopoly on the legitimate use of physical force within a given territory, 38 in other words, the exercise of legitimate authority. ${ }^{39}$ At the beginning the conquered group may resist the commands of its new master, but over time, acceptance of the new status quo becomes embedded into the resisting social group. At some point, absent revolution, it is likely that the new master will be seen as a legitimate source of command by the group or by the successors of the group that had been conquered, who will acknowledge and obey the master's commands as a legitimate authority. As long as there is a belief that those commands are legitimate, the ruled population will follow them without resistance. ${ }^{40}$

This idea of legitimacy constitutes an important aspect of the exercise of power of a given state, since it determines the binding nature of its rules and the likelihood of its survival in respect of its internal aspects. Legitimacy creates authority, the right to command and to be obeyed, as acknowledged by the general population. ${ }^{41}$ The grounds for the legitimacy of a source of power can be categorized, according to Weber, in three different groups: rational grounds, ${ }^{42}$ traditional grounds ${ }^{43}$ and charismatic grounds. ${ }^{4445}$

Until recently the idea of the state, and the exercise of power and authority was strongly linked to the ruler as a person, who was considered to possess and even embody

\footnotetext{
38 Or over a certain population. Robert Paul Wolff, In Defense of Anarchism (Harper \& Row 1998) 3.

39 The concept of legitimate authority used here is not the morally justified legitimate authority, but the sociologically accepted one. To this extent, legitimacy within this context is the obedience by a group of people to the commands of a given source. See Max Weber, The Theory of Social and Economic Organization (The Free Press 1947) 124-32.

40 See ibid 324-29.

41 Wolff 4-5 (n 38).

42 '[R]esting on a belief in the "legality" of patterns of normative rules and the right of those elevated to authority under such rules to issue commands (legal authority).' Weber, The Theory of Social and Economic Organization 328.

43 '[R] esting on an established belief in the sanctity of immemorial traditions and the legitimacy of the status of those exercising authority under them (traditional authority)' ibid .

44 ' $[R]$ esting on devotion to the specific and exceptional sanctity, heroism or exemplary character of an individual person, and of the normative patterns or order revealed or ordained by him (charismatic authority).'ibid .

45 Ibid 328-29.
} 
the institutions of the state personally. ${ }^{46}$ From the old monarchical state to the more modern one based on popular sovereignty, this concept has changed, attributing to it a double impersonal character; the state authority is distinguishable both from the rulers entrusted with the exercise of such authority as well as the authority of the society over which the power of the state is exercised. ${ }^{47}$ As the state is seen as having its own authority, there is a fundamental change in the source of its legitimacy, that is, a shift from the traditional and charismatic grounds to the rational one. ${ }^{48}$ This idea of impersonal power brings with it the necessity of the articulation of the rules and processes that will govern the polity through objective determinations. The 'subjective and arbitrary will of particular men' is excluded, and those wielding power may even suffer sanctions if they decide to follow the path of arbitrariness, in disconformity with the general rules that are deemed to govern the state. ${ }^{49}$ This is what is known as the Rule of Law, and it is usually attributable to a core of rights attributed to the population of a given state, guaranteeing them minimum political rights. ${ }^{50}$

One important aspect for the exercise of legitimate power is the existence of a theory on the source of the state's power that is justifiable, at least to an extent that the

${ }^{46}$ Quentin Skinner, 'The State' in Robert Goodin and Philip Pettit (eds), Contemporary Political Philosophy: An Anthology (Blackwell Publishing 2006) 9.

47 Ibid 13.

${ }^{48}$ Not that the charismatic and traditional grounds are meaningless, just the weight that they have in the justification of the exercise of power by the state is reduced, while the weight given to the rational ground is increased.

${ }^{49}$ Christopher Pierson, The Modern State (Routledge 2011) 15-16.

50 Tom Bingham translates the Rule of Law through a few principles:

'(1) [t] he law must be accessible and so far as possible intelligible, clear and predictable [;] (2) [q]uestions of legal right and liability should ordinarily be resolved by application of the law and not the exercise of discretion [;] (3) [t]he laws of the land should apply equally to all, save to the extent that objective differences justify differentiation [;] (4) [m]inisters and public officers at all levels must exercise the powers conferred on them in good faith, fairly, for the purpose for which the powers were conferred, without exceeding the limits of such powers and not unreasonably [;] (5) [t] he law must afford adequate protection of fundamental human rights [;] (6) [m] eans must be provided for resolving, without prohibitive cost or inordinate delay, bona fide civil disputes which the parties themselves are unable to resolve [;] (7) [a]djudicative procedures provided by the state should be fair [;] (8) [t] he rule of law requires compliance by the state with its obligations in international law as in national law.' Bingham 37; 48; 55; 60; 66; 85; 90; 110 (n 2). 
justification is accepted by the majority of the general population governed by the relevant state. ${ }^{51}$ The theory of choice in the western world is that of democracy.

Notwithstanding the various types of democracy, ${ }^{52}$ the overarching idea behind the theory is seductive to justify the exercise of power by the state over its population. Democracy's basic framework consists of treating each person equally and requiring a majority for a decision that will bind others. This is a very simplistic concept of democracy, ${ }^{53}$ but it is intuitive and provides an easy explanation that can be engaged by the population that the system of rules by which they are bound has in fact, as its source of power, the population itself, since they legitimize the exercise of power through their vote. As a legitimating mechanism for states, democracy is so important that even manifestly autocratic governments try to engage its convincing attributes, even if merely rhetorically, to advance their image as legitimate wielders of power. ${ }^{54}$

Democracy and the Rule of Law tend to go together in modern states. The exercise of the state's power is based on a legal infrastructure, which is anchored on a constitution that guarantees minimal rights to the population for the exercise of political rights, preventing an 'undemocratization' of society. ${ }^{55}$ These rights have to be preserved by institutional mechanisms that offer effective protection; the concept of the Rule of Law is suited for the task. Having an impersonal state, with decision makers and mechanisms to balance the exercise of power within the state structure, the Rule of Law has to be built

\footnotetext{
51 The minority who disagree with the exercise of power by the state will nonetheless be subject to it, having the order imposed on them. Weber, The Theory of Social and Economic Organization 132 (n 39).

52 For a brief overview on the different types of democracy, see Amy Gutmann, 'Democracy' in Robert E. Goodin, Philip Pettit and Thomas Pogge (eds), A Companion to Contemporary Political Philosophy vol 2 (Blackwell Publishing 2007).

${ }^{53}$ Robert Talisse called it the schoolyard view of democracy. Robert B. Talisse, 'Democracy' in Gerald Gaus and Fred D'Agostino (eds), The Routledge Companion to Social and Political Philosophy (Routledge 2013) 608.

54 The example that jumps to mind is the 1964 military coup in Brazil, characterized as the 'Democratic Revolution of 1964' by the dictatorship. The military forces still insist in teaching their trainees that what happened at the time was a democratic revolution, even though it is historically clear that there was nothing democratic about the 'Democratic Revolution'. For an account on the military dictatorship in Brazil, see Elio Gaspari, A Ditadura Envergonhada, vol 1 (Companhia das Letras 2002) Elio Gaspari, A Ditadura Escancarada, vol 2 (Companhia das Letras 2002) Elio Gaspari, A Ditadura Derrotada, vol 3 (Companhia das Letras 2003) Elio Gaspari, A Ditadura Encurralada, vol 4 (Companhia das Letras 2004).

${ }^{55}$ Not all modern societies have a Constitution to limit the sovereign's power. For example, in the U.K. the Parliament is seen as the sovereign, having the power to change any rules that exist in the political system. See Albert Venn Dicey, The Law of the Constitution (Oxford University Press 2013) 27-49.
} 
around institutional mechanisms that arbitrate the exercise of power within the state itself, guaranteeing democracy through a prearranged set of rules ${ }^{56}$ and preventing the takeover of the state structure by a tyrant.

The importance of the Rule of Law also goes beyond the political question of justifying the exercise of power, touching upon various economic problems, as will be explained below. The economic benefits that legal rules can bring to the organization of society and to the functioning of markets is an essential theme underlying this work.

\section{The Modern State, the Rule of Law and the Judiciary}

The last section was concluded with the assertion that democracy and the Rule of Law tend to go together in modern states. This is a question of the distribution of power within the inner political workings of the state and its authority over those who are ruled. Law is, by essence, rationally-justified, legitimate commands from the state ${ }^{57}$ over those being ruled.

However, legal systems are not a given in every single political society. As mentioned above, many states were merely the extension of the power of a specific person or a group of persons; these persons would do what they wanted and as they pleased. At some point during its development, a state might have been 'legalized'. Legalization is nothing more than the application of the Rule of Law ideal to the governance of the state and the exercise of the state's power, in the sense that the rulers will be bound by rules not deriving exclusively from their own will; the exercise of the state's power will only be legitimate if such rules are followed.

\footnotetext{
${ }^{56}$ The questions posed in such a political system will have to be decided by a human, since the exercise of power presupposes the human will. A rational basis for the interpretation and application of the rules guaranteeing democracy is, to a great extent, also a mechanism guaranteeing legitimacy, since wellarticulated decisions are more convincing than arbitrary ones. As long as there is a belief that the decisions within society have a rational basis and can be traced back to its democratic source and the norms guaranteeing it, legitimacy is more likely to be guaranteed.

57 Or a similar institution, for those who see law outside the state.
} 
Within the Rule of Law ideal, rules form the constraints of the political system, ${ }^{58}$ but their legitimization is only operational to the extent that they are justifiable; it is here that the democratic ideal comes into play.

In democracies, the democratic aspect of the state is the aspect that, from a power and authority perspective, backs and sustains the legal system anchored in a 'rule of recognition'. This is a rule 'for conclusive identification of the primary rules of obligation',59 those that bind the population in a certain way. The rule of recognition lays the parameters for identification of the validity of a given rule within the legal system; one of them being the identification of the political body of the state that is authorized to promulgate rules, which can thus be considered the ruler of the population. 60 The problem arising is that if the population is not satisfied with the rulers that are embedded in this system, they may decide to launch a revolution and destroy the political system in place, together with the rule of recognition and the legal system established by it. Revolutions do not tend to constitute easy paths, bringing violence, a waste of resources and social paralysis that are better being avoided. Democracy, as an ideal, is an adequate concept to avoid these results, since it is the exercise of power by the people. By institutionalizing democracy within the legal system - and in consequence, also in the political system - the people do not need to engage in a messy revolution in order to change the rulers, but need only decide, through an orderly process, that new rulers should assume the place of those with whom they have come to be discontented, ensuring the legitimacy and continuity of the state and its legal system. ${ }^{61}$ Of course, revolution outwith the legal rules still is possible, but as long as the majority supports the system in place, the revolutionary activity will most likely be unsuccessful. ${ }^{62}$ Since rule through democracy is highly justifiable and acceptable by the general population, the duo of the

\footnotetext{
58 The foundational rule of a political system is their respective Constitution.

59 H.L.A. Hart, The Concept of Law (Oxford University Press 1994) 95.

${ }^{60}$ Not all rules of recognition need to identify the body that promulgates rules, but it is hard to envision a modern state that possesses a rule of recognition without this characteristic since the rules would then be completely static.

${ }^{61}$ A good discussion on this idea of democracy as a system for revolution can be found in Jean Hampton, 'Democracy and the Rule of Law' in Ian Shapiro (ed), The Rule of Law: Nomos XXXVI (New York University Press 1994) 32-38.

62 Ibid 37.
} 
Rule of Law and democracy is a good combination for the provision of stability to a political system that decides to adopt it.

The characteristics that have been presented thus far for a modern legal system are the existence of a rule recognizing the rules that are binding on the population and the rules that are binding on the population, backed by a democratic system of empowerment. These rules regulate not only the relationship between the sovereign and subject, but also the relationships between subjects. The role of the Rule of Law and the rules on private transactions is also important for economic development, as it provides the foundations for people to transact without having to use significant resources to ensure their own protection. ${ }^{63}$

In this scenario, there still is something missing; this consideration relates to the institutions that, when a conflict arises, will decide on the particular case, that is, on who has broken a rule of the system. This role falls to the judiciary, ${ }^{64}$ which has a double function within society: firstly, acting as a buffer between the rulers and the ruled and guaranteeing that the rules of the legal system are observed; and secondly, acting as the umpire of the legal rules applicable to private relationships.

The rationale and importance of this second role of legal institutions in the economic area is the next topic of discussion.

\section{The Economic Function of Law on Private Matters and Dispute}

\section{Resolution}

Economically, legal institutions are important for two main reasons: A) they create rules which economic actors can use to protect their investment and plan their economic activity and B) they reduce market inefficiencies in specific markets. In addition, a third reason in support of the two mentioned above is that $\mathrm{C}$ ) legal institutions also provide a mechanism to solve disputes arising out of relationships based on A and B.

\footnotetext{
63 See the discussion below on section 3.

64 Hart 96-98 (n 59).
} 


\section{A. Basic Structure: Property and Contract Rights}

Property and contract rights are important mechanisms for the economic organization of private matters, ${ }^{65}$ being the basic legal instruments that allow for the planning and execution of economic activities.

The same logic for the appearance of states is also that underpinning the appearance of property rights within the state. States appeared as the consequence of power disputes for the control of scarce resources, such as the landlocked agricultural areas of Peru and of the most productive margins of the Amazon River. Within a more stable set of social relationships, the more the population grew the more people had to organize themselves in terms of the exercise of economic activity, ${ }^{66}$ distributing land and allowing for the use of the natural structure available in an orderly manner. ${ }^{67}$

There are at least three main problems that property rights are designed to address: a) the overuse of resources leading to its depletion; ${ }^{68}$ b) the avoidance of disputes on the use of a resource; and c) the incentive to invest.

These three objectives are all tied together and are based on the same source of concern, which is scarcity. If everyone can have access to a scarce good, such as fish in a pond, their capture will soon deplete the reserve available if there is no means to control

\footnotetext{
${ }^{65}$ Private matters are understood as the relationships between individuals or individuals and governments acting in their private capacity, and not on a governmental or regulatory role.

${ }^{66}$ The relationship between the size of the population and the scarcity of resources is essential to understanding the genesis of property rights. It is interesting to quote the statement of Blackstone, back in $18^{\text {th }}$-century England: 'But when mankind increased in number, craft, and ambition, it became necessary to entertain conceptions of more permanent dominion; and to appropriate to individuals not the immediate use only, but the very substance of the thing to be used. Otherwise innumerable tumults must have arisen, and the good order of the world been continually broken and disturbed, while a variety of persons were striving to get the first occupation of the same thing, or disputing which of them had actually gained it.' 2 William Blackstone, Commentaries on the Law of England 4 (1766) in Richard A. Epstein (ed) Economics of Property Law (Edward Elgar 2007) $\mathrm{x}$.
}

${ }^{67}$ After property rights are established, the actual contours of the institute and the specific types of division of property in a given society, thinking on a scale from commonly-held property to individually-held property, will be a function of the relationship between transaction costs and exclusion costs. See Barry C. Field, 'The Evolution of Property Rights' (1989) 42 Kyklos 319 An ancient system that has been widely studied is the Roman Legal System, which had a well-developed body of property law. See Andrew Borkowski, Borkowski's Textbook on Roman Law (Oxford University Press 2010) 151-204.

${ }^{68}$ This is known as the tragedy of the commons. See Garrett Hardin, 'The Tragedy of the Commons' (1968) 162 Science 1243. 
the rate of extraction compared to the rate of reproduction. The second point is that scarce goods that have value will lead to disputes among people that want to use them, creating a waste of energy that could be focused on other, more productive, activities. Finally, people will only invest energy in a given enterprise, be it the construction of a house or the farming of land, if there is some sort of guarantee that they will be able to enjoy the proceeds of their investment.

Property rights and an efficient legal system would diminish these costs. ${ }^{6970}$ By having clearly defined rights and a centralized dispute resolution system, people would not need to engage in arguments and/or physical power disputes to settle who has the right to a given property/resource, since they would be able to go to the dispute resolution system for the decision, which would then be enforced through the state mechanisms designed for such a purpose.

In economic terms, a primary function of property rights is to internalize externalities. ${ }^{71}$ Extensive research has shown that strong property rights and efficient enforcement mechanisms can be an important catalyst to the development of economic activities. ${ }^{72}$ These studies have demonstrated that property rights can play a crucial role in economic activity and economic development, but poorly-designed property rights may actually have the reverse effect, pushing a given economy into a 'tragedy of the anticommons', where 'multiple owners are each endowed with the right to exclude others

${ }^{69}$ One caveat, judicial disputes also consume resources, but they arguably constitute a better mechanism for the resolution of disputes than full-fledged warfare.

${ }^{70}$ On the tragedy of the commons problem, there are arguably three solutions: one is privatization, the attachment of property rights to common property and its division amongst its users, with a dispute resolution system to back it up as we are discussing here; the second is centralization, in other words regulation through the state; and finally, self-regulation through binding contracts, with the necessity of an external actor for enforcement. See Elinor Ostrom, Governing the Commons: the evolution of institutions for collective action (Cambridge University Press 1990) 1-28.

71 ('What converts a harmful or beneficial effect into an externality is that the cost of bringing the effect to bear on the decisions of one or more of the interacting persons is too high to make it worthwhile [...]. "Internalizing" such effects refers to a process, usually a change in property rights, that enables these effects to bear [...] on all interacting persons.')Harold Demsetz, 'Towards a Theory of Property Rights' (1967) 57 American Economic Review, Papers and Proceedings 347, 348.

72 See e.g. Hernando de Soto, The Mystery of Capital: Why Capitalism Triumphs in the West and Fails Everywhere Else (Bantam Press 2000) ; On the importance of strong investor protection, see e.g. Rafael LaPorta and others, 'Legal Determinants of External Finance' (1997) 52 The Journal of Finance 1131; Rafael LaPorta and others, 'Investor Protection and Corporate Valuation' (2002) 57 The Journal of Finance 1147. 
from a scarce resource, and no one has an effective privilege of use', ${ }^{73}$ leading to its underuse. ${ }^{74}$ In any event, when properly designed, property rights are an important mechanism for the development of capitalist societies, being used for the distribution and control of scarce resources and the channeling of energy into economically-productive activities.

Parallel to property rights, contract law also has an important economic function in enhancing economic outputs in a given society, as they are also designed to internalize externalities. ${ }^{75}$ The difference of contract law compared to property law is the object of regulation; instead of regulating a bundle of rights opposable to a group of people, contract law focuses on promises made by individual parties to each other. The operation of contract law makes these promises binding, and the normative justification for the legal enforcement of promises is the belief that the enforcement of promises is more beneficial than it is harmful to society, therefore creating a net social gain. ${ }^{76}$

\section{B. Imperfect Markets and Regulatory Law}

Due to power imbalances, the basic framework for private ordering may become inadequate, as those with more power may be able to exploit those with whom they engage in transactions. This is true in many different markets where one party has an advantage over the other, such as the labor market, securities market, and consumer market, amongst others. Exploitation and power imbalances can lead to inequitable situations, which can create market inefficiency and/or social unrest.

The second goal of the state and the use of legal institutions is to create substantive rules and standards to avoid such situations, prohibiting behavior that is unfair and creating mechanisms that can diminish market imperfections in the relationship of

\footnotetext{
73 Michael A. Heller, 'The Tragedy of the Anticommons: property in the transition from Marx to Markets' (1988) 111 Harvard Law Review 621, 624.

${ }^{74}$ This was common outcome in the transition from socialism to capitalism in the eastern European societies. See ibid.

75 Charles J. Goetz and Robert E. Scott, 'Enforcing Promises: an examination of the basis of contract' (1980) 89 Yale Law Journal 1261, 1276.

${ }^{76}$ Ibid 1286. For an economic explanation on the benefits and detriments of promises and the justification of some contract law rules, see the full article.
} 
private parties. ${ }^{77}$ The need for regulatory law was understood even in $19^{\text {th }}$-century England, when freedom of contract was deemed an important principle to be upheld, ${ }^{78}$ both in the judiciary ${ }^{79}$ and the legislative branches of government. ${ }^{80}$ In this sense, regulatory law is a mechanism which is used to achieve social justice. ${ }^{81}$

As these rules influence the private ordering of the parties they must be justified, ${ }^{82}$ be it on collective interest grounds or moral grounds. ${ }^{83}$ The justifications to regulation tend to be market specific; in general, in the securities field, regulation is justified on the broad grounds of market inefficiency and investor protection. A deeper analysis of the topic is undertaken in Chapter IV.

Often regulatory rules are aimed at correcting problems that have an effect on the economy, diminishing transaction costs and enhancing economic outputs when designed and deployed in an efficient manner. Enforcement mechanisms are essential to their success.

\section{The Role of Dispute Resolution Mechanisms}

As shown in the previous sections, legal rules are designed to diminish transaction costs amongst parties, creating certainty for future behavior, allowing parties to plan and

\footnotetext{
77 Hence the regulatory character they assume.

${ }^{78}$ See generally, Patrick S. Atiyah, The Rise and Fall of Freedom of Contract (Clarendon Press 1979) 219-570.

${ }^{79}$ For example, by the 1860 s the caveat emptor doctrine was weakened with cases such as Bigge v. Parkinson [1862] 7 H. \& N. 955, 158 E.R. 758 and Jones v. Just [1868] L.R. 3 Q.B. 197. After these cases, caveat emptor was only to be applied in situations where the buyer had examined the goods sold, which had to be specific, and had exercised judgment. On generic goods the seller was responsible for their merchantability. This is clearly a 'consumer common law', which displaces the 'freedom of contract' formerly available. See ibid 474-75

80 In the legislative, there were many statutes that limited freedom of contract and regulated private relationships, such as The Trade Union Act of 1871, The Truck Act of 1818 and the modifications came with The Poor Law of 1795, The Trade Union Act of 1871, The Anti-Truck Act of 1818 and The Passengers Act of 1803, among others. For an overview of the legislation on the period that influenced freedom of contract, see ibid.

81 On different concepts of social justice, see Hans- W. Micklitz, The many concepts of social justice in European private law (Edward Elgar 2011) 3-57.

82 Even in $19^{\text {th }}$ Century England freedom of contract was viewed as the starting point and any interference with it had to be justified. See Atiyah 386 (n 78).

83 See Roger Brownsword, 'The Theoretical Foundations of European Private Law: a time to stand and stare' in Roger Brownsword and others (eds), The Foundations of European Private Law (Hart Publishing 2011) 161-64.
} 
invest in activities that they know will be protected, while at the same time correcting imbalances that exists in specific markets. Since these rules need to be effective, an enforcement system has to be in place. Within modern society where states exist and claim a monopoly on the use of force, the legal enforcement system, since it is a system that if necessary can use force to achieve its ends, will have to be anchored in the power of the state, with institutions designed to facilitate enforcement. On practical terms, this means a wide array of mechanisms, from the police officers that will protect property to technological systems that may block bank accounts with a simple order from a judge.

Enforcement can be initiated by public institutions or by private parties, either before the harmful event occurs or afterwards. Generally speaking, public enforcement emphasizes deterrence while private enforcement emphasizes compensation and the fulfillment of private interests. ${ }^{84}$ While this is the classical distinction, private parties also have a role in enforcing regulatory rules, either on an individual basis or by becoming 'private attorney generals' to defend the interests of a collective. ${ }^{85}$ This is one of the underlying themes of this work and will be developed further in Chapter 4 .

Private legal enforcement is the second step to the problem of a dispute arising within a social context. Before any rule can be enforced, it is necessary to firstly establish what the rule is in the specific dispute and to then apply it. ${ }^{86}$ For the execution of these two functions, modern western states have institutions, the judiciary, and rules shaping the development and solution of the disputes and the enforcement of the outcomes. Through adjudication, 'the legal process of deciding a dispute', 87 courts produce two outcomes: the resolution of a dispute, which is beneficial to the parties of the dispute since it solves their problem with finality without resorting to aggression; and rule-making,

\footnotetext{
${ }^{84}$ Christopher Hodges, 'Public and Private Enforcement: the practical implications for policy architecture' in Roger Brownsword and others (eds), The Foundations of European Private Law (Hart Publishing 2011).

85 William B. Rubenstein, 'On What a "Private Attorney General" is - and Why it Matters' (2004) 57 Vanderbilt Law Review 2129.

${ }^{86}$ Many times when rules are clear and information asymmetry is low disputes will not arise because it will be clear who will prevail.

${ }^{87}$ See 'adjudication', Bryan A. Garner, Black's Law Dictionary (West Publishing Co. 2004).
} 
which in clarifying a certain aspect of the rules governing economic activities, attributes a higher degree of certainty to future cases and is therefore socially beneficial. ${ }^{88}$

The creation and maintenance of these systems of law and the dispute resolution, as well as these enforcement institutions, have a cost attached to them and are only worthwhile as long as there is a critical mass of people and transactions in which the aggregate costs of self-dealing would be higher than having them mediated and solved through the alternative legal channel. In simpler terms, the social benefits of the existence of laws and courts have to be higher than the costs of maintaining them.

One character of these institutions is that they have been formed by human beings who possess their own incentives to act in a certain way. Judges have to be wellremunerated and immune from political influence to be able to exercise their duty of deciding disputes according to the Rule of Law. Otherwise corrupt pressures might be too strong to be resisted and the essence of the Rule of Law would itself be compromised, transforming the court into just another political forum and destroying any economic benefits that the legal system might attribute to private relationships. This theme will be further developed in Chapter VI.

\section{Concluding Remarks}

This chapter tried to establish the relationship between states, law and dispute resolution, assessing it with a view to the economic utility of these institutions.

The state is a creature of political organization that has arisen out of long-lasting disputes amongst different human groups. Within the state the legal system serves economic purposes by giving rights to people and allowing them to engage in binding commitments to exchange resources, as well as correcting market failures when they appear and where they operate to undermine the economic health of a given market.

When there are disagreements regarding the rights or the commitments that people have towards each other or towards the state, an available forum is necessary to

\footnotetext{
${ }^{88}$ Robert D. Cooter and Daniel L. Rubinfeld, 'Economic Analysis of Legal Disputes and Their Resolution' (1989) XXVII Journal of Economic Literature 1067, 1092-93.
} 
effectively solve these disputes; this is a role that has been normally performed by the state through its court system. The role of the state is to function as a source of trust; the state becomes the guarantor that the counterparty in a transaction will behave according to the rules, either imposed by the state or agreed upon between the parties. This allows for people to plan and make investments based only on the guarantee that rules will govern their relationships with other parties. This is especially important in the context of regulated markets such as financial markets, as the identities of the counterparties to a transaction are often unknown.

As different states have different sources legitimating their power, each legal system is often closed within itself, 89 operating through its own internal logic and having few mechanisms to communicate with other states. Therefore, in the transnational context, legal mechanisms have to be built as bridges between different legal systems in order that transnational transactions can have the economic benefits that the legal system can provide.

The chapters in Part III will analyze the institutional framework of dispute resolution systems, identify the characteristics that they should have in order to perform this role in society and discuss the different designs that can be used to achieve such an aim; finally, it will survey the possible regimes that can be used for transnational dispute resolution.

\footnotetext{
${ }^{89}$ On the autopoietic nature of legal systems, see Gunther Teubner, Law as an Autopoietic System (Blackwell Publishers 1993).
} 


\section{Part II - Securities Regulation}

Securities are an important tool of finance. They are used both to raise new capital through traditional bond and equity issuance and also to transfer risk through the process of securitization. Securities represent a bundle of rights in a company, be it a property stake on the assets of a company or the right to claim repayment of a sum in the future. ${ }^{90}$

The mechanism is only useful to the extent that companies can obtain funding or shift risks without much expense, or at least without engaging a much greater expense than what would have been necessary through other financing mechanisms. This is only possible when strong securities markets are in place, but as with any other type of market, securities markets may be prone to failures.

The framework of different securities regulatory regimes have been a consequence of the failures that have led to many serious financial crises in this last century, especially in the United States. Reforms have been aimed at addressing the specific problems, recognized as the sources of these crises, and in many instances, they have been harshly criticized as creating more harm than benefits or not promoting enough change.

The concept of 'securities' as a legal tool is embedded in these regulatory regimes governing the rights of the parties that are issuing, selling, buying and overseeing the whole process. The legal operation of these regimes is tied to national jurisdictions. The rules and norms by which a firm issuing securities will be bound depends on where the securities will be sold, the actors selling or advising on these securities and the possible overreach of distinct jurisdictions. Thus, while a Brazilian company may sell securities in the U.S. Market, the rules that that company will have to abide by are those of the United States.

The strength of securities markets is therefore dependent on the institutional framework surrounding the activity of securities issuance and commercialization, from

\footnotetext{
${ }^{90}$ George W. Arnett, Global Securities Markets: Navigating the World's Exchanges and OTC Markets (John Wiley \& Sons, Inc. 2011) 1030.
} 
prudential supervision by government agencies and self-regulatory organizations to the redress mechanisms available to investors, the latter being the focus of this work.

Before engaging in any discussion concerning the actual dispute resolution mechanisms in this area of law, it is first important to understand the theoretical underpinnings of these regulatory mechanisms and their substantive legal aspects, the black-letter law that purports to regulate actor's behavior within these regimes and the grounds for redress.

The objective of this part is to establish the theoretical importance of securities regulation and establish the legal rules that are applied in the jurisdictions under study; it is divided as follows: Chapter III discusses the financial crises underpinning the creation of and reforms to the securities regulatory regime in the United States; ${ }^{91}$ Chapter IV explains the theoretical discussions and empirical evidence for the benefits of a system of securities regulation and the role of private litigation within it; finally, Chapter $V$ analyses the legal framework for liability in securities transactions and identifies the types of disputes that can arise out of it.

\footnotetext{
${ }^{91}$ The focus on the U.S. is that it is the country where a comprehensive system of securities regulation was first drafted and with which the other two systems under study have many similarities In fact, through the Agency for International Development, Brazil requested assistance from the SEC to draft its securities regulations. Norman S. Poser, 'Securities Regulation in Developing Countries: the Brazilian Experience' (1966) 52 Virginia Law Review 1283.
} 


\section{Chapter III - Financial Crises and Securities Regulation}

In the last century, financial crises played a major role in creating and reshaping securities regulation. After any major financial crisis, a political uprising would occur and cries for reforms to prevent the abuses perpetrated by market actors would be made. Then, laws would be passed and reforms would be executed. A common cycle throughout history is identifiable: investors enter into a speculative behavior, forgetting about reality and embracing a dreamland of endless moneymaking, while the market, or at least its smartest actors, start engaging in transactions that add fuel to the fire, making a considerable amount of money in the process; this continues until the bubble bursts, triggering dire economic consequences which lead to a regulatory reform process. ${ }^{92}$

This has largely been the case with the U.S. system of securities regulation, a true creature of crises. ${ }^{93}$ The federal system of securities regulation was set up a few years after the crisis of 1929, while the accounting scandals of 2002 and the subprime mortgage crisis of 2008 also triggered important reforms. ${ }^{94}$ The phenomenon also seems to be the same in the UK, which also had a financial system reform rooted in scandal. ${ }^{95}$

Of course, this is not true for the securities regulation regime of every single jurisdiction. The European Union, for example, has not engaged in this reactive type of regulatory reform. The proposals for regulation and the effective changes made have rather been well thought out and discussed in advance, with a focus not only on investor protection, but also on the harmonization of the European markets. ${ }^{96}$

\footnotetext{
92 See Larry E. Ribstein, 'Bubble Laws' (2003) 40 Houston Law Review 77, 164 (discussing the 'boom, bust, regulation' cyclical pattern).

93 Stuart Banner, 'What Causes New Securities Regulation? 300 Years of Evidence' (1997) Washington University Law Quarterly 849, 850.

${ }^{94}$ See the sections below.

${ }_{95}$ Niamh Moloney, 'Financial Services and Markets' in Robert Baldwin, Martin Cave and Martin Lodge (eds), The Oxford Handbook of Regulation (Oxford University Press 2010) 438.

96 Ibid 438-39.
} 
In any event, these regulations are designed to address possible market failures. A minimal understanding of the history behind the major financial crises is important to the extent that it can help to identify the processes that led to the failures that caused these crises in the first place. The question to be answered is 'what historical events have shaped securities regulation?' This chapter briefly explains the three main crises that led to a reform in securities regulation in the United States.

\section{The Financial Crash of 1929 and the Creation of the Securities Regulation Framework in the United States}

The backbone of the legal regime of securities regulation in the US was enacted after a period of great panic and loss in the securities markets and during an era of economic hardship. Just before entering the Great Depression, the United States experienced good economic development. The 1920s was a period of great optimism; production and employment levels were rising and many people were living better than they ever had. ${ }^{97}$ Excessive optimism, however, has a tendency to create bubbles. ${ }^{98}$

The first significant bubble in this period was the boom of the Florida real estate market. Houses were being sold at more than double the price for which they had been sold a few years before, and opportunistic 'entrepreneurs', such as Mr. Charles Ponzi, were selling non-existent real estate developments. ${ }^{99}$ Speculation was rampant, with purchasers entering the market with the exclusive intent of reselling their rights to the property at a profit. ${ }^{100}$ The introduction of binders, a legal mechanism that gave the right

\footnotetext{
${ }^{97}$ John Kenneth Galbraith, The Great Crash: 1929 (Houghton Mifflin Company 1997) 1-3.

${ }_{98}$ Especially if coupled with easy monetary policy, as it was the case with the Florida real estate bubble at the time. The Federal Reserve had lowered its discount rate from $4.5 \%$ in the end of 1922 to 3\% in the second quarter of 1923. See William B. Stronge, The Sunshine Economy (University Press of Florida 2008) 98.

${ }^{99}$ See Galbraith 4-5 (n 97).

100 Stronge 97 (n 98).
} 
to the buyer on the property without the effective transfer on public registries for thirty days, simply facilitated the process. ${ }^{101}$

In 1926, the real estate market in Florida collapsed. The problem began with a lack of workers who could continue construction as it was demanded, the logistical problems of the area and the increasing awareness of the unethical practices engaged by real estate promoters. ${ }^{102}$ Then, in September 1926, a hurricane struck the region, causing severe damage and putting an end to any speculative activity that would otherwise have still been in place. ${ }^{103}$

At the beginning of 1928, the same speculative frenzy and make-believe mindset took over the stock market in New York. ${ }^{104}$ The amount of broker's loans, used for purchases of securities on margin, 105 was on the rise, increasing from $\$ 3,480,780,000^{106}$ at the end of 1927 to $\$ 6,000,000,000$ at the end of $1928 .{ }^{107}$ This was a clear sign that speculation was escalating.

At the same time, in order to keep pace with the necessities of the market and the willingness of people to put their money in stocks and bonds, investment trusts were being created. ${ }^{108}$ These trusts were so popular and their managers so well-regarded that their securities value was superior to the underlying assets that they had, sometimes achieving a premium of $100 \% .^{109}$

Within this environment, fraud and manipulation were also common. Some investment banks were not sufficiently careful in verifying the health of the companies

\footnotetext{
101 Binders were introduced because the recording offices in Florida were overloaded with work, and they were used to guarantee the rights until transfer would be made. Ibid 98.

102Ibid 100-02.

103 Ibid 102.

104 Galbraith 11-14 (n 97).

105 Purchases of securities where the broker loans the money to the purchaser and the security is kept by the broker as collateral.

106 This was already a significant amount, since in the early twenties the value of these loans floated around one to one and a half billion dollars.

107 Galbraith 11-14 (n 97).

108 During the years of 1928 and 1929, around 451 investment trusts were created. Ibid 21.

109 Ibid 49-50.
} 
they were underwriting; in other instances, they had outright knowledge as to the worthlessness of the underwritten securities, but had no interest as they would subsequently dump them in the market through aggressive marketing strategies. ${ }^{110}$ Other actors would also manipulate securities prices; common instruments that could be engaged to do so included the creation of parallel markets and the facilitation of market manipulation through short sales ${ }^{111}$ and high-volume stock purchases. ${ }^{112}$

In October 1929, after a year of strong appreciation, 113 the New York Stock Exchange experienced a crash that put the market into a downward spiral, resulting in a loss of $87 \%$ of market value by mid-1932.114 The stock market crash was a sign of the bad times that were coming, constituting, for many, the beginning of the Great Depression. ${ }^{115}$

The federal statutes for securities regulation were enacted as responses to the market failures that had led to the crash. ${ }^{116}$ While state securities regulations had existed since 1911,117 the 'blue-sky'118 statutes were problematic. They could barely be enforced across state lines, leaving fraudsters from other states practically immune to these laws. ${ }^{119}$ Moreover, evidence shows that the information provided on offering circulars before the enactment of the securities laws of 1933 and 1934 were poor, conveying inadequate information to allow for an informed investment decision. ${ }^{120}$

110 Ibid 53-54.

111 Short sale is the sale of stock without owning it. Usually the stock is borrowed and sold, and has to be given back at a later date. Short sellers expected the stock price to drop, so they can repurchase the stock in the market at a lower price and return it to the owner, making a profit on the transaction.

112 James Burk, 'The Origins of Federal Securities Regulation: A Case Study in the Social Control of Finance' (1985) 63 Social Forces 1010, 1016.

113 From the date Herbert Hoover accepted its Republican nomination, on August 12, 1928, to September 19, 1929, the New York Times Industrial Average rose from 257.98 to 460.2, a 44\% increase. See ibid .

${ }^{114}$ Compared to the market's peak value before the crash. See ibid .

115 For an overview of the Great Depression, see Daniel Leab and others, The Economic Depression (ABCCLIO 2010) 2-6.

116 See Eric Rauchway, The Great Depression \& the New Deal: a Very Short Introduction (Oxford University Press 2008) 62.

117 The first securities regulation statute was enacted in Kansas. See 'Securities Commission' (West Virginia State Auditor's Office) <https://www.wvsao.gov/securitiescommission/history.aspx> accessed 7 July 2014.

118 The term used for States' securities statutes in the U.S.

119 See Burk (n 112).

120 Ibid. 
The Securities Act of 1933 and the Securities Exchange Act of 1934 intended change this situation. ${ }^{121}$ The 1933 act was designed to impose disclosure duties on issuers of securities to better inform investors as to their decisions, while the 1934 act created the Securities and Exchange Commission and regulated stock exchanges and ongoing disclosure duties for issuers.

\section{The Sarbanes-Oxley Reform}

The Sarbanes-Oxley Act of 2002 was the result of concerns arising out of major scandals related to the corporate governance structure of American corporations. Enron ${ }^{122}$ and Worldcom were the iconic examples of corporate failure of this period. These two cases were a culmination of a growing pattern of accounting irregularities in the 1990 s. ${ }^{123}$

One of the relevant dimensions of the market leading to these instances of fraud, was the incentives structure of compensation schemes, common in countries in which there is dispersed share ownership. Compensation through stock options is likely to lead to fraudulent behavior on the part of management since there is an incentive to inflate the company's numbers for a higher option's market value. ${ }^{124}$

The abuses perpetrated by Enron were possible because of the accounting standards in place at the time, which allowed for the use of present values for its trading business, ${ }^{125}$ and also by its extensive use of structured finance. ${ }^{126}$ The first problem arose

\footnotetext{
${ }^{121}$ For a historical overview of the acts and the creation of the SEC, see Joel Seligman, The Transformation of Wall Street: A History of the Securities and Exchange Commission and Modern Corporate Finance (Northeastern University Press 1995).

122 For a narrative of the events on Enron's scandal, see Bethany McLean and Peter Elkind, The Smartest Guys in the Room: the Amazing Rise and Scandalous Fall of Enron (Penguin Books 2003).

123 From 1990 to 1997, the number of accounting restatements in the U.S. was around 49 per year, rising to 156 in 2000. See John C. Coffeee Jr., 'A Theory of Corporate Scandals: Why the United States and Europe Differ' in Joseph J. Norton and Jonathan Rickford (eds), Corporate Governance Post-Enron: Comparative and International Aspects (British Institute of International and Comparative Law 2006) 6.

124 Ibid 10.

125 This valuation process is known as mark-to-market accounting. It valuates an asset according to its market price, which in some instances may be determined through the anticipation of future income.

126 Paul M. Healy and Krishna G. Palepu, 'The Fall of Enron' (2003) 17 Journal of Economic Perspectives 3, 9.
} 
out of the practice of recognizing future expected income from projects as revenue, where it was far from certain that such projects would be viable. ${ }^{127}$ The second problem was that Enron deliberately used Special Purpose Entities to manage its financial reports, hiding debts and risks that otherwise should have been disclosed. ${ }^{128}$ To make matters worse, the fundamentals of Enron's businesses were not exactly in the best shape. ${ }^{129}$

These problems have an important relationship to the underlying purposes of securities regulation, which is to provide reliable information to investors. That is to say, the information provided by Enron was deeply misleading as to the health of its businesses, showing a glowing picture of a deeply rotten business model.

The reasons as why it took so long to detect the issues, and as to how they grew so much, have been explained as an informational intermediaries' incentives problem. ${ }^{130}$ The corporate governance system had design flaws that led many of the relevant intermediaries to overlook accounting issues that were at the core of the abuse, while the regulatory system was not well suited to prevent them. Arthur Andersen, one of the biggest accounting firms at the time and Enron's auditor, was fatally wounded with the scandal and ceased its operations. ${ }^{131}$ The firm had not only failed to identify the financial misstatements that were pervasive through Enron's financial statements, ${ }^{132}$ but they also actively engaged in destroying documents when it became likely that lawsuits would soon start. ${ }^{133}$

\footnotetext{
127 One example is a 20-year contract with Blockbuster where Enron would store and distribute entertainment content through its broadband network. Enron recognized estimated profits of $\$ 110$ million, even though it was not clear whether the project was viable. See ibid 10.
}

128 See William C. Powers Jr., Report of Investigation by the Special Investigative Committee of the Board of Directors of Enron Corp. (2002); Steven L. Schwarcz, 'Enron and the Use and Abuse of Special Purpose Entities in Corporate Structures' (2001-2002) 70 University of Cincinnati Law Review 1309.

129 See Healy and Palepu 6-10 (n 126).

130 See John C. Coffee, 'What Caused Enron? A Capsule Social and Economic History of the 1990s' (20032004) 89 Cornell Law Review 269.

131 See Kathleen F. Brickey, 'Andersen's Fall from Grace' (2003) 81 Washington University Law Quarterly 917.

132 Gary M. Cunningham and Jean E. Harris, 'Enron and Arthur Andersen: the Case of the Crooked E and Fallen A' (2006) 3 Global Perspectives on Accounting Education 27, 43.

133 Brickey 919-21 (n 131). 
The political response was an overhaul of the accounting and disclosure regulatory system, in order to address the specific issues that took these companies down; this was facilitated through the Sarbanes-Oxley Act of 2002.134 With a focus on investor protection, the act was designed to change the practices surrounding the corporate governance and accounting of publicly traded companies.

The main changes introduced by the act were the creation of the Public Company Accounting Oversight Board, an oversight body for accounting audits on public companies, 135 the imposition of rules for auditor independence, 136 the creation of a financial statements certification duty for the officers of the company ${ }^{137}$ and enhanced financial disclosures. ${ }^{138}$

These changes were designed to provide for better disclosure of information, both through a change in the institutional framework of the regulation of auditors and also by increasing the liability of corporate officers through the duty to certify financial statements. While heavily criticized in academic literature,139 the Sarbanes-Oxley Act of 2002 has stood its ground without any major reforms in almost 10 years.

\section{The 2008 Crisis and its Consequences for Securities Regulation}

The crisis in 2007-2008 was the result of many different dimensions of the American economy and its financial system. Cheap credit fueled an already-growing

134 The Enron case was also useful to stir discussions on corporate governance matters in Europe. See Paul L. Davies, 'Enron and Corporate Law Reform in the UK and the European Community' in Klaus J. Hopt and others (eds), Corporate Governance in Context: Corporations, States and Markets in Europe, Japan, and the US (Oxford University Press 2005).

135 Sarbanes-Oxley Act of 2002, ss 101-109.

136 Sarbanes-Oxley Act of 2002, ss 201-209.

137 Sarbanes-Oxley Act of 2002, ss 301-305.

138 Sarbanes-Oxley Act of 2002, ss 401-409.

${ }^{139}$ See Roberta Romano, 'The Sarbanes-Oxley Act and the Making of Quack Corporate Governance' (2005) 114 Yale Law Journal 1521. 
housing bubble that had been developing since 1997,140 leading to a classic boom-andbust scenario.

The increase in easy credit was a political response to the increasing income inequality that had been mounting in the United States. From 1975 to 2005, the income of those who earn more than the other $90 \%$ of the general population rose by around $65 \%$, compared to those that are in the $10^{\text {th }}$ percentile. ${ }^{141}$ Failing to deal with the situation through better education and unable to put forward income redistribution reforms, easier credit seemed the only politically feasible way to improve the livelihood of the general population. ${ }^{142}$ The policy was advanced through lower interest rates established by the Federal Reserve System ${ }^{143}$ and the use of government-sponsored entities promoting lending to low-income people, enabling them to afford housing. ${ }^{144}$

With the increasing availability of mortgages in the market, the private sector realized that they had a new business opportunity: they could buy mortgages, bundle them together and sell them to investors, creating profits in a relatively low-risk activity. ${ }^{145}$ The process was undertaken via special purpose vehicles, corporate entities which had, as their only raison d'être, the holding of mortgages and the issuing of securities to be sold on the market. ${ }^{146}$ In practice, this meant that these banks would not hold any risk on these mortgages; as long as they could be bundled and sold, banks would

\footnotetext{
140 From 1997 to 2006 house prices increased at an annual rate of 9.3\% while building costs at a rate of 2.9\%. See Marc Jarsulic, Anatomy of a Financial Crisis: a Real Estate Bubble, Runaway Credit Markets, and Regulatory Failure (Palgrave Macmillan 2010) 12.

${ }^{141}$ Raghuram G. Rajan, Fault Lines; How Hidden Fractures Still Threaten the World Economy (Princeton University Press 2010) 24.

142 See ibid 24-31.

143 By November 2002 the Federal Reserve lowered the federal funds interest rate to $1.25 \%$, set at $6.5 \%$ in 2000. John Cassidy, How Markets Fail: the Logic of Economic Calamities (Farrar, Straus and Giroux 2009) 222.

144 The two main government sponsored entities that had a role in the crisis were Fannie Mae and Freddie Mac. See David Reiss, 'Fannie Mae and Freddie Mac and the Future of Federal Housing Policy: a Study of Regulatory Privilege' (2010) 61 Alabama Law Review 907.

145 This practice of financial institutions was begun in the 1990s. See The Financial Crisis Inquiry Commission, The Financial Crisis Inquiry Report (2011) 68.

146 This process is known as securitization. Through securitization, the credit risk of the investment can be isolated from the credit risk of the originator, not only facilitating the transaction that can be priced according just to its fundamentals, but also freeing originators from the credit risk of some of their assets. For more information about securitization, see Muñoz (n 21).
} 
not have a strong incentive to carefully scrutinize them. This mortgage business model became known as the 'originate-to-distribute' model and was key in creating systemic risk in the market.

While mortgages were being securitized and distributed to the market, a demand from banks for this kind of asset was growing. Mortgage brokers were doing their job, but they also had an extra incentive to provide the mortgages that banks wanted: the higher the interest rate paid by the mortgagee, the higher the broker's commission. ${ }^{147}$ The quality of the loan did not really matter, since in the end they would be pooled and sold to investors, what did matter was that there were loans to be used. The practice deteriorated to the point that loans were being made to persons with no income, no jobs and no assets - the infamous NINJA loans. ${ }^{148}$

While the quality of these loans was suffering considerably through the passage of time, investors were still happily buying mortgage-backed securities. Investors relied on Credit Rating Agencies to provide information about the risk of these products being sold instead of doing their own due diligence; at the same time, the Credit Rating Agencies were functioning as regulatory licensees, distributing licenses and being paid by the securitizers themselves to rate their products. ${ }^{149}$

The excess credit that was created through this practice led to a rise in United States' housing prices. From 1997 to 2006, housing prices were increasing at a rate of 9.3\%; meanwhile building costs were rising at a rate of only $2.9 \% .{ }^{150}$ This was a growing bubble, becoming ripe to burst.

\footnotetext{
147 This kind of commission was known as the 'yield-spread premium'. A higher interest rate, of course, would increase the likelihood of default. The Financial Crisis Inquiry Commission, The Financial Crisis Inquiry Report (2011) 90.

148 NINJA loans were a consequence of the incentive system in the market at the time; for brokers, it was important to create as many loans as possible, with the worst possible terms to the borrowers, while for the financial institutions securitizing these loans it was important just to have them and pass them along. The incentive system led to a lax screening of the mortgages being originated, and the market became populated with a high amount of low quality loans. See Benjamin J. Keys, Did Securitization Lead to Lax Screening?: Evidence from Subprime Loans in Robert Kolb (ed) Lessons from the Financial Crisis: Causes, Consequences, and our Economic Future (John Wiley \& Sons 2010).
}

${ }^{149}$ Brian J.M. Quinn, 'The Failure of Private Ordering and the Financial Crisis of 2008' (2009) 5 NYU Journal of Law \& Business 549, 567-82.

${ }^{150}$ Jarsulic 12 (n 140). 
The stage was set for disaster. In 2006, the crisis started to unravel. Housing prices started to fall, homeowners were increasingly becoming unable to service their mortgages and by mid-2008, almost $4.5 \%$ of the subprime mortgages outstanding in the market were foreclosing. ${ }^{151}$ Even though there were a lot of investors buying these products, many of the financial intermediaries were also holding a substantial amount of them. Massive bank failures began to occur; ${ }^{152}$ a downward spiral was triggered, pushing markets into a nosedive. The Dow Jones Industrial Average reached its lowest point during the crisis on March 9, 2009, hitting 6.547 points. ${ }^{153}$

As the subprime crisis evolved in the U.S., international markets also started feeling its effects, while the real economy suffered the consequences. ${ }^{154}$ The expanding effects of the crisis prompted many policy responses and calls for reform all over the globe, leading to a restructuration of the global financial architecture. ${ }^{155}$

These reforms, contrary to what had happened after the accounting scandals in the United States, did not substantially alter the general liability framework of the players in securities issuance. In particular, cases reporting duties were modified, ${ }^{156}$ additional duties in specific financial transactions were required 157 and disclosure duties enhanced, 158 mainly when related to Asset Backed Securities. The reform had an

151 Robert W. Kolb, The Financial Crisis of Our Time (Oxford University Press 2011) 61.

152 Bear Sterns, Lehman Brothers, Countrywide Financial, Washington Mutual and IndyMac were extinguished, while Wachovia and Merryl Lynch were acquired by Wells Fargo and Bank of America. See ibid 74.

153 The Dow Jones was at 14,165 points on October 9, 2007. This was a fall of almost 54\%.

154 See Dirk G. Baur, Contagion and the Real Economy During the Global Financial Crisis in Robert W. Kolb (ed) Financial Contagion: The Viral Threat to the Wealth of Nations (John Wiley \& Sons 2011) Even though the U.S. subprime crisis might have been the fuse of the global crisis, many other countries also had been developing similar patterns of housing credit expansion. See FinANCIAL SERvicEs Authority, THE TuRNER REviEW: A REgulatory RESPONSE TO THE GLOBAL BANKING CRISIS (2009).

155 In the U.S., the reform of the system was done through the Dodd-Frank Wall Street Reform and Consumer Protection Act in 2010, while in the EU the change came through the creation of the European System of Financial Supervision, a new framework for financial markets regulation at the European level. See Regulation (EU) 1092/2010, Regulation (EU) 1093/2010, Regulation (EU) No 1094/2010 and Regulation (EU) $1095 / 2010$.

156 See Suspension of the Duty to File Reports, SEC Release No. 34-65148 (August 17, 2011).

157 For example, the duty to perform a review regarding the assets used on an Asset-Backed Security. See Issuer Review of Assets in Offerings of Asset-Backed Securities, Securities Act Release No. 33-9176 (January 20, 2011).

158 See Disclosure for Asset-Backed Securities, SEC Release No. 33-9175 (January 20, 2011). 
increased focus on avoiding systemic risk. ${ }^{159}$ On the other side of the Atlantic, in Europe, the reforms were mainly institutional, where the concern was focused more on facilitating a regulatory system where financial risks could be addressed at the European level.160

\section{Concluding Remarks}

Financial crises have been one of the factors shaping the American system of securities regulation. Each of these crises discussed here had a different market failure that led to the crash of the financial system, resulting in long-lasting reforms to the regulatory landscape in the United States.

The importance of understanding the reasons that led to the creation and reform of the U.S. system of securities regulation is that it was the first well-known system of securities regulation and has served as a model to the creation of other systems. The market failures that the U.S. system addresses are the same as those that the other regulatory systems purport to address. This chapter thus provides a historical introduction to the theoretical discussion of securities regulation, which is undertaken in the next chapter.

${ }^{159}$ For example, one of the provisions was studying a requirement to impose a minimum percentage of their own products that securitizers had to hold, imposing a 'skin in the game' requirement. See Dodd-Frank Act; see also Board of Governors of the Federal Reserve System, Report to the Congress on Risk Retention (2010). 160 See Jacques de Larosière, The High-Level Group on Financial Supervision (2009). 


\section{Chapter IV - Securities Regulation Theory and the Importance of Private Enforcement}

The concept of 'securities' is an important one to financial markets. A 'security' is a legal mechanism used at the heart of many financial transactions. The underlying idea is of an 'an investment pooled with others and managed by third parties with whom the investors participate in the economic fate of a common enterprise'. ${ }^{161}$ Through its formal materialization, a security becomes a product and can be sold like anything else.

The consistent buying and selling of securities creates a market for these products. Like any other market, its proper functioning is dependent on the relationship of the parties that form part of it. In the absence of other mechanisms, for private parties, trust and the fear of reputational harm are the cornerstones of their functioning. Since these mechanisms are not perfect, market failures may arise, compromising market efficiency. ${ }^{162}$

As with any other markets, there is a legitimate interest that securities markets work efficiently. Efficient markets avoid waste of resources. In some aspects, especially where securities markets are well developed, its efficiency is crucial for the economy of a country, and any pathology that might be developed within the market is unwanted and has to be remedied.

As discussed in the preceding chapter, financial and securities regulation reform has often been implemented after a financial crisis, targeting specific market problems that at the time were seen as deficiencies that could have caused, or contributed to the

\footnotetext{
${ }^{161}$ Arnett 1030 (n 90).
}

162 Usually the more impersonal markets are, the less these personal mechanisms are efficient. Highly personal markets tend to use more reputational and trust mechanisms, as it can be seen from Lisa Bernstein's research on the diamonds industry and the cotton market in Memphis. See Lisa Bernstein, 'Opting Out of the Legal System: Extralegal Contractual Relations in the Diamond Industry' (1992) 21 Journal of Legal Studies 115 Lisa Bernstein, 'Private Commercial Law in the Cotton Industry: Creating Cooperation through Rules, Norms, and Institutions' (2000-2001) 99 Michigan Law Review 1724. 
crisis. Within this context, the questions to be answered in this chapter are the following: 'what is the role of securities regulation?' and 'what is the best method of enforcement?'

The objective of this chapter is thus to provide an overview of the literature on securities markets structures, and of the institutional mix in securities regulation and then to finally establish the importance of private enforcement in this area.

\section{The Market}

A market is where the exchange of goods or services takes place, regardless of whether it is a physical location or not. ${ }^{163}$ The level of supply and demand determines the prices of a given good on the market. For example, if the world's coffee production is reduced in a year due to adverse weather conditions and the demand stays relatively the same, the price of coffee will rise due to the smaller supply until it reaches its equilibrium level for the new situation. ${ }^{164}$ The equilibrium level is achieved through price adjustment due to the new conditions of supply and demand. In this example, the price rises because coffee consumers do not have as much coffee available to them as before, and those who value coffee will be willing to pay a higher amount to get the same quantity of coffee. The price ceases to rise when buyers reach the threshold of what they will accept to pay for a given quantity of coffee.

Markets are not entities that pre-exist trade. Individuals engaging in transactions make markets, each with their own personalities, preferences and tastes. The importance attached to a given product depends on individual opinions about it. If no one likes coffee and would not even take it home for free, a coffee market would be unlikely to develop. This is an important aspect of a market; it is not a structure that adjusts automatically to a change in reality, but any change is dependent on the individual decisions of every single person transacting in it.

\footnotetext{
${ }^{163}$ See 'market', Jonathan Law and John Smullen, A Dictionary of Finance and Banking (Oxford University Press 2008).

164 The 'equilibrium quantity and price' is the level of price and quantity of a given product where both buyers and sellers are satisfied. See Robert Frank, Microeconomics and Behavior (McGraw-Hill Irwin 2010) 29-32.
} 
The understanding of a market as a place where transactions are made brings further implications. Transactions, in the real world, have costs. Even if parties would have complete knowledge about a product, they would either have to get together to close the deal or ask someone to do it for them; in either case, time and energy would be spent. Complete knowledge is also an assumption that does not hold true in the real world, as parties have to obtain information about the product they want to purchase. A person buying a used car will want to know about the quality of the car, the problems it has and the adversities it was put through before the deal. Everything else being equal, a car in bad shape is less desirable than a car that has been given proper care. Knowledge acquisition is also a cost that is pervasive in any type of market.

Developing rules and institutions for a market has the objective of diminishing these costs, therefore increasing its efficiency. An economically efficient market should provide for the lowest possible transaction cost. Of course, each market has its own characteristics and weaknesses that may warrant different types of rules.

\section{The Functioning of Capital Markets}

Capital Markets are a specific type of market with the function of allocating economic resources efficiently. In a very simplistic representation, there are two sides to a Capital Market structure: the savers and the entrepreneurs. The savers want to defer their expenses and not use their capital at the present time, while the entrepreneurs want to use capital to invest in 'new capital' that will create value in the future. ${ }^{165}$ The decision to make an investment through third-party financing is based on the price of a given security. The transaction depends on what the saver believes a given security is worth trading his money for and whether the entrepreneur is willing to accept such value in comparison with the future income streams that he may be willing to forgo given the value creation possibilities of the project. ${ }^{166}$ If their expectations are the same, the transaction will take place and the saver will be able to have his savings remunerated for future

165 See Jeffrey N. Gordon and Lewis A. Kornhauser, 'Efficient Markets, Costly Information, and Securities Research' (1985) 60 New York University Law Journal 761, 767-70.

166 For example, if the interest rate of borrowed money in the market is $10 \%$, a project will only be executed through debt financing if it can provide a higher income than that. 
spending while the investor will be able to execute a project that will create value and generate future income streams.

An efficient resource allocation maximizes the welfare of the population as a whole, avoiding unnecessary costs. The more developed Capital Markets are, the more efficient the economy and its growth will be. 167 The question here is not whether Capital Markets are beneficial. Any social structure that diminishes transaction costs and is able to increase the availability of goods to the population is welcome. The question is whether the regulation of these markets makes them more or less efficient.

To address this question it is first necessary to understand the inner mechanics of Capital Markets and the link between economic efficiency and market efficiency, which are distinct concepts in the literature. A market is more economically efficient if, all else being equal, its transaction costs are lower than in a comparable market. The concept of market efficiency is different: a market is efficient if it reflects all available information. ${ }^{168}$ The central concept of an efficient market is price accuracy. ${ }^{169}$ Markets where prices are inaccurate create unnecessary economic costs. ${ }^{170}$ The next two sections address: A) the mechanics of price accuracy and B) the costs of price inaccuracy.

\section{A. The Mechanics of Price Accuracy}

Price accuracy is dependent on the information available to the market regarding a certain security and its incorporation into the security's price. The premise of an

167 Robert G. King and Ross Levine, 'Finance and Growth: Schumpeter Might be Right' (1993) 108 The Quarterly Journal of Economics 717; Ross Levine and Sara Zervos, 'Stock Markets, Banks and Economic Growth' (1998) 88 The American Economic Review 537.

168 There is theoretical distinction between fundamental efficiency and informational efficiency. Fundamental efficiency is the ability of a market to reflect the best estimate of the future incomes of an asset, while informational efficiency is the inability to profit from available information because they are already reflected in the securities price. This distinction is only relevant to the extent that there are mechanisms to predict securities price more accurately than the market, given the same set of available information. Since this is an unlikely proposition, the distinction is not relevant for the purposes of this work, and the underlying concept used here for market efficiency will be informational efficiency. See Ronald J. Gilson and Reinier Kraakman, 'The Mechanisms of Market Efficiency Twenty Years Later: The Hindsight Bias' 446 Harvard Law School John M Olin Center for Law, Economics and Business Discussion Paper Series 1, 2.

${ }^{169}$ Gordon and Kornhauser 768 (n 165). If the price is not accurate the decisions made by investors and savers will not be optimal.

170 Therefore, there is also a link between market efficiency and economic efficiency. 
efficient market is that it 'fully reflects' all available information. ${ }^{171}$ The 'reflection of available information' is dependent on two factors: a) how information is incorporated into prices and b) how information is made available.

The incorporation of information into prices can be framed as a two-step process. Firstly, it depends on the number of potential investors that have access to a piece of information. Secondly, it depends on how these persons transmit this information to the market price of a security. The price adjustment is a function of the initial number of persons possessing the information and the amount of transactions that are made based on such information; the bigger the number of initial persons possessing the information and the bigger the transactions made based on it, the faster the information is incorporated into prices. ${ }^{172}$

The availability of information can be thought of as a continuum that goes from publicly available information to restricted information. Information requires effort to be gathered; this is reflected in the use of personal time or by hiring researchers. Even if it is publicly available, its pieces can be raw data that must be organized to be understood. The costs of organizing information coherently in such a manner that some use might be made of it might be high. Moreover, it may be necessary to check whether the information provided is true, an activity that has also has a cost. ${ }^{173}$ Therefore, the level of availability of a piece of information can be translated in terms of the cost to acquire, organize and reasonably rely upon it.

Due to the costs of obtaining, processing and verifying information, many different mechanisms have emerged to diminish these costs through economies of scale and scope. The press, financial intermediaries and individual networks are some of the avenues that are used for this purpose. Such mechanisms increase the initial availability of information to market participants. By diminishing information costs, they enhance price accuracy in

171 Eugene F. Fama, 'Efficient Capital Markets: a Review of Theory and Empirical Work' (1970) 25 The Journal of Finance 383, 383.

172 Liquidity therefore is an important aspect for market price efficiency, the more liquid the market, the faster is the price adjustment.

173 In sum, information costs can be divided into three categories: acquisition costs; processing costs and verification costs. For a more in depth overview, see Ronald J. Gilson and Reinier H. Kraakman, 'The Mechanisms of Market Efficiency' (1984) 70 Virginia Law Review 549, 597-609. 
capital markets by increasing the distribution of reliable information while also contributing to economic efficiency, both directly, through the reduction of informational costs, and indirectly, through a more efficient capital market.174

The second moment of price formation is the incorporation of available information into the prices of a product. In any given market, this 'reflection' occurs through different mechanisms. ${ }^{175}$ In the long-run, prices tend to adjust to equilibrium by incorporating new available information; the important question regarding price accuracy is how fast the information is incorporated into prices. ${ }^{176}$ The incorporation of information is basically done through transactions that are based on the new information. Actors using the information will evaluate and act on it, pushing securities prices up or down.

There are four mechanisms of information incorporation into prices: 'universally informed trading', 'professionally informed trading', 'derivatively informed trading' and 'uninformed trading', 177 which have a parallel in the cost structure mentioned above.

'Universally informed trading' is the situation where information is either already incorporated into prices, such as old information, or where the costs of obtaining it are so low that the market players will receive, process, adjust their expectations and act on it promptly, reaching near perfect efficiency. ${ }^{178}$

In cases where information is widespread but further analysis is necessary for it to be understood, professional traders play a bigger role, entering into the universe of the 'professionally informed trading'. Professional traders have better tools to analyze

174 There is an apparent paradox in the relationship between the cost of obtaining information and market efficiency. The premise of an efficient market is that any available information is 'fully reflected' in stock prices at any time. Therefore, if the market is efficient, any information that becomes available is fully reflected in the stock prices, and the costs of acquiring new information will not be worthwhile, pushing the market to inefficiency again. The paradox is just apparent. Since price systems are not perfectly efficient there is always an opportunity to make a profit from arbitraging, justifying the existence of information providers and arbitrageurs. See Sanford Grossman and Joseph Stiglitz, 'On the Impossibility of Informationally Efficient Markets' (1980) 70 The American Economic Review 393.

175 See Gilson and Kraakman 554-65 (n 173).

176 Ibid 559-60.

177 Gilson \& Kraakman, based on previous financial literature, elaborated these terms. See ibid 566.

178 Ibid 568-69. One example would be an oil spill that is widely televised across the globe. 
complex information that would not be meaningful to the unsophisticated investor. Professional trading is responsible for incorporating complex information into securities prices and it is an efficient mechanism so long as the trading volume, based on the new expectations that were formed from the analysis of such information, is sufficient to move the market price. ${ }^{179}$ As such, a certain consensus among professionals is needed for price movement.

The third mechanism, 'derivatively informed trading', functions when information is not widespread and the costs of acquiring it are higher. The few players that are in control of the information will be able to trade on it and profit from their behavior until the information is leaked or other market players are able to 'decode' it. In this case, the price will only adjust to the extent that other players are able to obtain the information on which the insiders are trading the security. This happens through two processes: 1) if the trades made by insiders are sufficient to move the demand or supply of the security or 2) if outsiders realize that insiders are executing the trade and decide to engage in the same trades under the belief that those insiders have more information than they do. ${ }^{180}$ There is a considerable gap in time from the moment when the new information is available to the insider to its incorporation into the security price; if insider trading volume is low and there are no other manners of outside traders to discover that insiders are trading their securities, the new information might never be incorporated into the price. This gap creates an informational asymmetry problem that may lead to an increase in transaction costs and an overall deterioration of the market. ${ }^{181}$

The last mechanism is 'uninformed trading', a mechanism based on soft information, belonging to the realm of predictions and forecasts. Each individual trader has opinions and beliefs that are used as a basis for engaging in certain trades. By trading

\footnotetext{
179 Ibid 569-72.

180 Gilson \& Kraakman term these two mechanisms as 'trade decoding' and 'price decoding'. Ibid 573.

181 This is the well-known 'lemons' problem. When there is informational asymmetry regarding products in the same class and the purchasers are not able to differentiate between a good product and a medium one, the tendency is for the purchasers to discount prices to compensate for the risk of buying a product of medium quality. Since the price will not reflect the real quality of the good product, their owners might no longer be willing to sell them. The same process then happens with the medium and the bad product, pushing it into a downward spiral that may lead to the extinction of the market. See George A. Akerlof, 'The Market for "Lemons": Quality Uncertainty and the Market Mechanism' (1970) 84 The Quarterly Journal of Economics 488.
} 
based on these beliefs, each and every single trader's expectation is transferred to the market price of the security. ${ }^{182}$ The adjustment of securities prices will be a mean average of each individual investor's expectations of what the price should be, and even though the market would behave as if its actors were informed, in fact they would not be. ${ }^{183}$

These four mechanisms are not exclusive; they complement each other and they may even operate concomitantly regarding the same piece of information. It is through these mechanisms that information incorporates into securities prices, adjusting its accuracy.

These mechanisms are shaped and limited by the institutional complexities surrounding the activities related to gathering, processing and verifying market information, as well as by the legal framework surrounding these processes. ${ }^{184}$

\section{B. Consequences of Price Inaccuracy}

Price inaccuracy in Capital Markets can bring different harmful effects to the efficiency of an economy. As discussed above, an inefficient economy wastes resources that could otherwise be used to maximize the well-being of the population. Identifying the social costs of price inaccuracy is important to further the discussion about the legal mechanisms that can be used to address them. The three main categories of social costs arising out of price inaccuracies are non-optimal capital allocation, market liquidity and corporate governance failures.

Non-optimal capital allocation: The investment decisions of a company based on inaccurate stock prices may be socially suboptimal. Both the overvaluation and the undervaluation of a company raising money in the primary market through equity offerings may lead to social costs. If the stock price is overvalued, the company may invest in projects that are suffering loss because selling new shares will overcompensate older

182 The 'uninformed trading mechanism' is based on three conditions: 1) a trader forecast is based on secondary information that is exclusive; 2) traders' forecasts are within an acceptable degree of variability within the market; 3) the aggregate market assessment is unbiased towards an hypothetical optimal price estimative of a fully informed trader. See Gilson and Kraakman 579-88 (n 173).

183 In fact, one of the premises for the 'uninformed trading' mechanism to work is that each trader is informed by 'secondary facts and evaluations to which only he has access'. Ibid 581.

184 See Gilson and Kraakman 35-37 (n 168). 
shareholders; ${ }^{185}$ on the other hand, if the stock price is undervalued, projects that could be socially valuable might be put aside if the stock price discount is higher than the expected added value of the investment. ${ }^{186187}$

Under this specific problem, price accuracy is important to the extent that it is present at the period when the company is going through the process of issuing new shares. The investment decision is made having in consideration the amount of capital that can be obtained during an offer in the primary market: it is meaningless, at least as a direct consideration of an investment decision, whether the security price is accurate before or after the process is undertaken. ${ }^{188}$

Market liquidity: Liquidity ${ }^{189}$ is both a cause and a consequence of price accuracy. As explained above, the higher the number of transactions in a given market, the faster is the incorporation of information into market prices, enhancing price accuracy. Liquid markets are markets where securities can be promptly transformed into cash, meaning that there is plenty of supply and demand for any person to buy or sell a given security.

Apart from the fairness argument of accurate prices for securities transactions, price inaccuracies affect investor confidence, which in turn affects market liquidity. Price inaccuracies are mainly caused by informational asymmetry. When this is the case and

185 Imagine a company with a fundamental value of $\$ 100$ million, with 100 shareholders having 1000 shares each. The fundamental value of a single share is $\$ 1000$. The market values the company at a $20 \%$ premium. The company has an investment opportunity that will need \$10 million in equity, but will increase the company value only by $\$ 9$ million. To raise this money the company needs to sell 8334 extra shares at $\$ 1200$. After the transaction is completed the value of the company will be $\$ 109$ million, with each share being worth $\$ 1006.14$. Even though the project is not socially optimal, the old shareholders of the company would execute it nevertheless since they would profit from it.

186 Imagine the same company, with its fundamental value of $\$ 100$ million, the 100 shareholders holding 1000 shares with a fundamental value of $\$ 1000$ each. The company now has an investment opportunity that will increase the value of the company by $\$ 11$ million, but the necessary equity to execute it is $\$ 10$ million. The company is trading at a $20 \%$ discount. To raise the capital it would be necessary to sell additional 12500 stocks. After the transaction each new share would be worth $\$ 986.67$. Even though this is a socially desirable project, due to the share value mispricing the stockholders would not approve its execution because they would be worse off after its completion.

187 See Marcel Kahan, 'Securities Laws and the Social Costs of "Inaccurate" Stock Prices' (1992) 41 Duke Law Journal 977, 1005-08. The two examples before are based on the examples offered in this article.

188 Ibid 1012-16.

${ }^{189}$ Market liquidity can be either the opportunity of finding a trade partner with which a large amount of trading can be made without causing market impact, or the possibility of converting securities into cash. Here market liquidity is used with this second meaning. For the first definition see Deutsche Bundesbank, Securities Market Regulation: International Approaches (Monthly Report January, 2006) 37. 
there is a consistent practice in the market of trading on non-public information, the individual uninformed investor will be more likely to lose on his transactions and eventually will become aware that such a market is rigged against him. Since such a transaction represents a higher risk of loss with the least possible benefit, the investor may become wary of trading in such an unfair environment. ${ }^{190}$ The withdrawal of investors who perceive the market as unfair to them will diminish the amount of trading, which translates into diminished liquidity.

Investors value liquid securities more than illiquid ones. Everything else being equal, a bond that pays $10 \%$ interest and can be sold in one hour is more valuable than a bond with the same interest rate that can be sold only after a week. Therefore, the first consequence of an illiquid market is the higher cost of raising capital that arises out of it. 191

The second cost arising out of a diminished liquidity relates to the cost of transactions within the market. Transactions in illiquid markets tend to be more costly than in liquid ones due to higher brokerage fees. ${ }^{192}$ Since a decrease in liquidity means a lower level of trade, brokers and market makers earn less from their activities, notwithstanding that they still have fixed costs that they must bear to provide their services. The consequence is that they have to widen the bid-ask spread to compensate for the loss of business. ${ }^{193}$

Corporate governance failures: Price inaccuracy can also have harmful social effects linked to the behavior of firm managers. Their behavior can be attached to securities prices in many different ways, ranging from direct ownership of stocks to a sense of duty to shareholders and the assumption that higher stock prices will be in their interest. ${ }^{194}$ Unless managers are shorting the stock of their company, their incentive

190 Kahan 1018-19 (n 187).

191 For a model on how informational asymmetry, liquidity and cost of capital are related see Douglas Diamond and Robert Verrecchia, 'Disclosure, Liquidity, and the Cost of Capital' (1991) 46 The Journal of Finance 1325.

192 Kahan 1020 (n 187).

193 See Hans R. Stoll, 'Market Microstructure' in George M. Constantinides, Milton Harris and René M. Stulz (eds), Handbook of the Economics of Finance, vol 1A (Elsevier 2003) 562-67.

194 Kahan 1029 (n 187). 
structure will be to increase the value of the company's securities prices, either because they own stocks or options or for shareholder's satisfaction.

If the price is accurate, the only way in which managers will be able to change the value of the company's securities will be through the improvement of its fundamental value. ${ }^{195}$ In perfectly efficient markets, managers, basing their decisions in stock prices, will not be able to cause socially harmful effects.

Within the corporate governance structure, inaccurate prices raises two issues: the first is, similarly to the social costs arising out of equity funding as discussed above, the decision of investing in non-optimal enterprises due to incentives accruing from the management interest in focusing on a higher priced company; the second is the use of signaling techniques.

The logic behind the first issue is the same as the one discussed in respect of the decision to offer securities to the public. If the company has some available capital and different options of investment, it may decide to opt for the choice that is less profitable but more valuable in the eyes of the market. The opportunity to pursue a more socially efficient option would be abandoned due to price inaccuracies in the market. ${ }^{196}$

The second issue is rather one of transaction costs than of allocative efficiency. Signaling is the transmission of information to the market. 197 The practice of signaling is undertaken to inform the market that the price of stock is undervalued. The practice of signaling has costs, and if the security price were accurate, management would not need to engage in signaling. Accuracy prevents the necessity of the company's use of signaling mechanisms to transmit information to the market.

\footnotetext{
195 Ibid 1030.

196 The inaccuracy here is not about the price of the manager's firm, but of the one where the investment is going to be made, even though the decision is made based upon the expected share price increase of the manager's firm.

197 For an overview of signaling, see Michael Spence, 'Signaling in Retrospect and the Informational Structure of Markets’ (2002) 92 The American Economic Review 434.
} 


\section{The Theoretical Justification for Securities Regulation}

Inefficient markets have consequences to the real economy; as such, increasing their efficiency is an important task. The economic efficiency of markets is developed through institutional design. There are different overlapping mechanisms that may be used for this purpose, but the creation of an institutional market framework has to be made with the specific market in mind.

Market efficiency is a byproduct of transaction costs, availability of information and its incorporation into prices. In the securities field, outside the domain of the market microstructure, which is concerned with the nuts and bolts of trading, the underpinning concept of securities regulation is 'information disclosure'. Narrowing informational asymmetry creates an environment for better-informed investors, who in turn then become more confident in engaging in financial transactions, contributing to market efficiency.

While financial markets are regulated everywhere, the idea of imposing disclosure duties on actors involved in securities transactions is not a unanimous one. The securities market and its regulation has been a heavily discussed topic since the introduction of the federal securities law in the United States. Initially its discontents criticized only specific provisions of the securities acts that were thought to impede capital formation, and none of these was aimed at disclosure. ${ }^{198}$ It was then in the 1960 s that a new wave of criticism emerged against the mandatory disclosure system. ${ }^{199}$

\section{A. The Argument against a Mandatory Disclosure System}

The initial criticisms against a mandatory disclosure system were based on the costs on corporations and the lack of evidence that mandatory disclosure was in fact necessary since corporations were already disclosing some information before the

\footnotetext{
${ }^{198}$ Joel Seligman, 'The Historical Need for a Mandatory Corporate Disclosure System' (1983) 9 The Journal of Corporation Law 1, 2.

${ }^{199}$ See George J. Stigler, 'Public Regulation of the Securities Markets' (1964) 37 The Journal of Business 117; Henry G. Manne, Insider Trading and the Stock Market (The Free Press 1966); George J. Benston, 'The Value of the SEC's Accounting Disclosure Requirements' (1969) 44 The Accounting Review 515.
} 
securities system reform. ${ }^{200}$ Moreover, insider trading was seen as something beneficial that could be used as means of rewarding entrepreneurs, therefore leading some commentators to argue that the prohibition of using inside information for trading could be harmful. ${ }^{201}$ Securities regulation, these studies preached, accrued few benefits for its costs. These arguments and the evidence used to reach these conclusions, were severely disputed; ${ }^{202}$ since then, much has been written on the subject.

Much of the new criticism is based on the assumptions arising out of the efficient market hypothesis, the efficiency of market mechanisms to promote the proper functioning of capital markets and the inefficiency of mandatory disclosure systems. ${ }^{203}$ Theoretically, if a firm were issuing securities to fund a project that was expected to be profitable, it would optimally disclose information to convince investors to buy those securities. ${ }^{204}$ The lack of disclosure by the firm would lead investors to think that they had only bad information about the project. This would imply that after it starts disclosing information, a firm would not be able to stop disclosing new information without triggering investors' concerns linked to non-disclosure. To guarantee that the optimal amount of information would be disclosed, the firm would then utilize market mechanisms, such as verification and certification, to 'borrow' financial intermediaries' reputations. ${ }^{205}$

Informational intermediaries would also be used to signal to the market that there are other types of information that, due to competitive advantages, are better not to be directly disclosed at that particular moment, such as a new technology. ${ }^{206}$ By disclosing information to specific intermediaries that have the possibility of buying enough

200 Benston 531 (n 199).

201 See Manne 139-41 (n 199).

202 For an overview, see Seligman, 'The Historical Need for a Mandatory Corporate Disclosure System' (n 198).

203 See Frank H. Easterbrook and Daniel R. Fischel, 'Mandatory Disclosure and the Protection of Investors' (1984) 70 Virginia Law Review 669; Lynn A. Stout, 'The Unimportance of Being Efficient: An Economic Analysis of Stock Market Pricing and Securities Regulation' (1988) 87 Michigan Law Review 613.

204 See S.J. Grossman and O.D. Hart, 'Disclosure Laws and Takeover Bids' (1980) 35 The Journal of Finance 323, 323-27.

205 Easterbrook and Fischel (n 203). The authors frame this idea as the principle of 'self-induced disclosure'. 206 Ibid 688. 
securities to influence its market price, issuers would be signaling to the market that they have beneficial information that cannot be publicly disclosed. ${ }^{207}$

Another criticism, focused more on the specifics of securities regulation in the United States, is about the quality of information provided. It advances that the focus of disclosure should be less on historical data but more on future projections, since stock prices are calculated on the basis of projected future income. ${ }^{208}$

These criticisms assume that markets, as a matter of principle, will always do better if left untouched than if regulatory mechanisms are imposed on them. This is, of course, not always true, as history has demonstrated over and over again. ${ }^{209}$

\section{B. The Argument for a Mandatory Disclosure System}

The opposing view is that a mandatory disclosure system for securities regulation does matter for share price accuracy and also that its costs are lower than the benefits that they accrue to society. This position can be generally based in the public goods character of information and the possible inefficiencies in the absence of a mandatory disclosure system as well as the flaws of the self-induced disclosure theory. ${ }^{210}$

Information is a public good because it is indivisible and unexcludable. ${ }^{211} \mathrm{~A}$ piece of information does not exhaust itself with its use; it will still be available to any other person who may want to use it. This allows persons that have not contributed to the costs of obtaining the information to use it for free. ${ }^{212}$ Since researchers will not be able to sell the information to all of its users, they will be undercompensated, and the consequence is that information tends to be underprovided. This under-provision of information is

207 This would fall within the insider-trading category.

208 Homer Kripke, 'The SEC, the Accountants, Some Myths and Some Realities' (1970) 45 New York University Law Review 1151, 1197-201.

${ }^{209}$ See Chapter III.

210 John C. Coffee, 'Market Failure and the Economic Case for a Mandatory Disclosure System' (1984) 70 Virginia Law Review 717, 722-23.

${ }^{211}$ For an overview of 'public goods', see Richard Cornes and Todd Sandler, The Theory of Externalities, Public Goods and Club Goods (Cambridge University Press 1996).

212 This is known as the free-rider problem. See Stanford Encyclopedia of Philosophy, 'The Free Rider Problem' (Stanford Encyclopedia of Philosophy, 21 May 2003) <http://plato.stanford.edu/entries/freerider/> accessed 7 July 2014. 
harmful because the less informed traders that are available to trade, the higher the amount of time necessary for the information to become incorporated into prices, a process which affects market efficiency.

A mandatory system of disclosure would not only address this problem, but it would also cut the duplication efforts that are made in collecting and processing information. Absent a mandatory disclosure system, many different analysts engage in obtaining, processing and verifying the same set of information about a company, wasting unnecessary resources. ${ }^{213}$

This first justification for a mandatory disclosure system is aligned with the idea underpinning the mechanisms incorporating information into market prices: it provides both for market efficiency through a wider base of information that reaches different persons faster and also for economic efficiency by diminishing duplicative economic efforts.

Another line of argument goes against the theory that firms would disclose all beneficial information by themselves. The self-induced disclosure theory can be empirically demonstrated in the market through the various financial institutions and gatekeepers that provide 'reputation' for companies that wish to signal the market. The question though is not if these mechanisms exist, but to what extent they are sufficient to provide proper and sufficient information to the market.

Conflicts of interest between ownership and control in the firm prevent an optimal self-induced disclosure. Even though the logic in the theory is sound, the premises of it are not. The lack of ongoing disclosures after a firm has started with the practice may signal to the market that there is bad news, and therefore the firm, as an institution, would disclose the information. The problem is that managers do not always have their interests aligned with those of the shareholders, and they might use this market response to pursue their own agenda. ${ }^{214}$

${ }^{213}$ Coffee, 'Market Failure and the Economic Case for a Mandatory Disclosure System' 733-34 (n 210).

${ }^{214}$ Ibid 737-47. 
The theoretical case in favor of mandatory disclosure seems to be stronger than that against. The next section reviews the literature on the effects of strong securities regulation and investor protection in the economy, which provides evidence that this is in fact the case.

\section{The Empirical Evidence for Securities Regulation}

Does securities regulation matter in practice? Is there any added value in having a system to control the manner in which securities are issued and the actions of the relevant actors in respect of its trading?

A body of literature demonstrates that securities law and more generally, corporate law, do matter to protect investors and to strengthen capital markets. The quality of legal rules and enforcement reflects on the size of capital markets. ${ }^{215}$ For example, shareholder protection is a determinant to the dispersion of shares ownership, influencing the ability of a firm to obtain external finance. ${ }^{216}$ The argument is that a developed legal system of investor protection, by guaranteeing the rights of investors and preventing expropriation, will incentivize investors to pay more for a firm's security since interest or profit will be more likely to come back to them than if such protection did not exist. ${ }^{217}$ This not only raises the value of the companies in general but it also allows investors to consider companies that would not have been considered absent good legal protection. ${ }^{218} \mathrm{~A}$ particular study has illustrated that firms that cross-list in the United States, which is known to have strong investor protection rules, have experienced an increase of up to $37 \%$ on their Tobin's q ratio ${ }^{219}$ compared to firms that are not crosslisted. ${ }^{220}$

${ }^{215}$ See LaPorta and others (n 72).

${ }^{216}$ See Andrei Shleifer and Daniel Wolfenzon, 'Investor Protection and Equity Markets' (2002) 66 Journal of Financial Economics 3.

217 Rafael LaPorta, Florencio Lopez-de-Silanes and Andrei Shleifer, 'Corporate Ownership around the World' (1999) 54 The Journal of Finance 471.

218 See generally LaPorta and others 1147 (n 72).

${ }^{219}$ The Tobin's q ratio is the value of the firm divided by the replacement value of the firm's assets. See ibid . ${ }^{220}$ See Andrew M. Chisholm, An Introduction to International Capital Markets (2nd edn, John Wiley \& Sons 2009) 165-66. 
Another argument that strong securities regulation is beneficial arises from the analysis of the costs of raising capital. Similarly, the literature also demonstrated that 'firms in countries with more extensive disclosure requirements and stronger securities regulation' have a lower cost of equity capital, even after other risk variables were controlled. ${ }^{221}$

Another article, also focused on the benefits to the economy of share price accuracy and the importance that mandatory disclosure systems have in accurate prices, reached similar results. ${ }^{222}$ Through the use of the $\mathrm{R}^{2}$ methodology, the study indicated that share price accuracy is important to capital allocation, ${ }^{223}$ while specific enhanced disclosure requirements - introduced in the US in the 1980s - showed an increase of information reflection in share prices. 224

The conclusion that can be drawn from this literature is that there is an important relationship between developed capital markets and their regulation. Securities regulation is a tool to promote market efficiency, and an efficient institutional framework, designed to address problems arising out of the development of financial markets, is important to economic development.

\section{Securities Regulation in the EU}

The idea of economic integration remains one of the central aspects of the EU project, the goal of a single market being one of its most pressing objectives. ${ }^{225}$ In the TFEU, the basis of the single market is reflected in the four freedoms: free movement of

${ }^{221}$ See Craig Doidge, G. Andrew Karolyi and René M. Stulz, 'Why are Foreign Firms Listed in the U.S. Worth More?' (2004) 71 Journal of Financial Economics 205.

222 Merritt B. Fox and others, 'Law, Share Price Accuracy, and Economic Performance: the New Evidence' (2003) 102 Michigan Law Review 331.

223 Ibid 366; see also Jeffrey Wurgler, 'Financial Markets and the Allocation of Capital' (2000) 58 Journal of Financial Economics 187.

${ }^{224}$ Fox and others 368-80 (n 222).

225 For a brief overview of the economic aspects of economic integration, see Ali El-Agraa, 'The Theory of Economic Integration' in Ali El-Agraa (ed), The European Union: Economics and Policies (9th edn, Cambridge University Press 2011). 
goods, workers, establishment and the provision of services, and capital. ${ }^{226}$ This logic is also applicable to securities regulation, focusing on the construction of an integrated EU securities and investment services market,227 with the consequence that any EU securities regulation has to be justified as a means towards the construction of the single market, as there is no other basis for regulation.

Primarily, the approach to this area of regulation was based on maximum harmonization, attempting to equalize the different regulatory regimes in the Member States in order to remove the barriers arising from them. ${ }^{228}$ Due to negotiation difficulties and the implementation discretion that was given to Member States, this first attempt failed. 229

The next regulatory approach was based on the 'mutual recognition' principle established in the Cassis de Dijon ${ }^{230}$ judgment, establishing a minimum harmonization framework where supervision is delegated to the home country of the service provider/issuer and the host country is obliged to accept such regulation, without imposing any additional burdens. ${ }^{231}$ This approach also failed because there was still much power with the host Member State regarding issuer-disclosure and investment services, inhibiting the development of an integrated market. ${ }^{232}$

These deficiencies were acknowledged and in 1998 a Financial Services Action Plan with 42 measures was devised and implemented to address these problems and to change the framework of the EU financial and securities regulation. ${ }^{233}$ Today the EU is

\footnotetext{
226 TFEU, art 26; See Paul Craig and Gráinne De Búrca, EU law text, cases, and materials (Oxford University Press 2011) 581-82.

227 Niamh Moloney, EC Securities Regulation (Oxford University Press 2008) 6.

228 Ibid 9.

${ }^{229}$ Ibid .

${ }^{230}$ Case 120/78 Rewe-Zentral AG v Bundesmonopolverwaltung für Branntwein (Cassis de Dijon) [1979] ECR 649.

${ }^{231}$ Moloney, EC Securities Regulation 9-10 (n 227).

232 Ibid 10.

${ }^{233}$ See ibid .
} 
becoming the 'monopoly supplier of financial market regulation', ${ }^{234}$ creating a regulatory level playing field among EU Member States and enabling market integration.

Therefore, in addition to the importance of securities regulation as means to address the market failures discussed in this chapter, there is also a more important objective, at least under the EU logic, which is the creation of a single market for securities and investment services. This is relevant because the rules on securities regulation at EU level have to be enacted based on this principle, due to the limitations of EU regulatory competence.

\section{Public Law and Private Law in Securities Disputes}

The common conceptual distinction between public law and private law is that the first has the goal of pursuing collective goals, while the second serves as a regulatory background for private transactions to take place. ${ }^{235}$ Even though conceptually this is a clear-cut distinction, in practice the relationship between these two legal domains is much more intertwined.

The reality is that not only can private law be shaped by public law, but that public law may also need to rely on private law to achieve its goals. ${ }^{236}$ This is especially relevant in the field of securities regulation where many of the regulatory standards enshrined in what would be considered within the domain of public law, e.g. standards used for supervision duties, create expectations for the parties engaging in private transactions, and in many instances actually serve as the basis for private law redress.

Private standards can be the basis for the creation of public standards, which in turn can be used to create duties within private law. An interesting example of this public/private relationship in the field of investments is the duty to one's client when providing investment advice. The duty started as a purely private law standard in the

234 Ibid 37.

${ }^{235}$ Andrew Robertson, 'Introduction: Goals, Rights and Obligations' in Andrew Robertson and Tang Hang Wu (eds), The Goals of Private Law (Hart Publishing 2009) 5-6.

${ }^{236}$ See generally Mayo Moran, 'The Mutually Constitutive Nature of Public and Private Law' in Andrew Robertson and Tang Hang Wu (eds), The Goals of Private Law (Hart Publishing 2009). 
Bond case in Germany, being transposed to the public law realm with its inclusion in MIFID, ${ }^{237}$ an instrument used for supervision standards. ${ }^{238}$ The journey back to the private law realm is evident when the national instruments transposing MIFID are used as a basis for liability in a private relationship, ${ }^{239}$ as is allowed in many jurisdictions, either directly or indirectly. ${ }^{240}$

Within the EU context, this relationship is an important one since differences in the interaction between public law and private law may create wholly different private law regimes, despite the harmonized supervisory approach; this might create difficulties for the single market due to the divergent private law standards being applied in different Member States.

\section{Institutional Aspects of Securities Regulation: The Importance of Private Enforcement}

Assuming the premise that regulation is beneficial, as demonstrated throughout this chapter, a whole new set of questions becomes relevant. The design of the regulatory regime has to take into account many different aspects. What is the regulatory body in charge of the regime? What are its powers? How will the people in charge of the regime be hired? Who will finance it? How will the rules be developed? What might be the punishment for non-compliance? Who will enforce this punishment?

These questions are a small sample of the wider considerations that should be engaged while deciding on the main dimensions of a regulatory system. The two spheres of regulation are the public, where the government designs and deploys a regulatory system, and the private, where private parties create a regulatory system to provide for their own needs. In many instances, these two different spheres become intertwined, each

\footnotetext{
${ }^{237}$ Art 19(4).

238 Olha Cherednychenko, 'European Securities Regulation, Private Law and the Investment Firm-Client Relationship' [2009] European Review of Private Law 925, 931-37.

239 Ibid 937-46.

${ }^{240}$ Ibid 946-51.
} 
in charge of specific functions of the regulatory system. ${ }^{241}$ The moment where this interplay occurs is at the norm-setting stage and at the enforcement stage. Both public and private actors might set the standards and both might also enforce rules made by themselves or by other actors. The division of power between public and private, however, is of extreme importance to align the interests of the different parties in a manner to ensure that the regime will achieve optimal efficiency in respect of its proposed goals. Badly designed regulatory systems may fail, leading to unnecessary costs. ${ }^{242}$

The objectives of this section are firstly, to set out the basic general framework of the regulatory regime in securities regulation and then to establish the importance of private enforcement in satisfying the policy objectives of investor protection and strong markets.

\section{A. The Regulatory Regime - Institutional Aspects}

The design of a regulatory regime can be divided in three different parts: the first is the determination of who should be empowered to create the rules of the regime; the second is the rules with which compliance should be required, that is, what the regime expects the regulatees to do; finally, it must be determined how these rules will be enforced to guarantee that the right incentives are in place so that the regulatees comply with the rules. In respect of the enforcement aspect, the system can be further subdivided into ex ante and ex post mechanisms. ${ }^{243}$ Ex ante mechanisms are those where compliance with the rules are checked before a harm arises, ${ }^{244}$ while ex post mechanisms are those

${ }^{241}$ For an overview of developments regarding the private and the public regulatory sphere see Fabrizio Cafaggi, 'Rethinking Private Regulation in the European Regulatory Space' (2006) 2006 EUI Working Papers 13.

242 For an overview of regulatory failure, see Robert Baldwin, Martin Cave and Martin Lodge, Understanding Regulation: Theory, Strategy, and Practice (2nd edn, Oxford University Press 2012) 68-82.

243 For a brief discussion of the subject, see Samuel Issacharoff and Ian Samuel, 'New Frontiers of Consumer Protection: the Interplay Between Private and Public Enforcement' in Fabrizio Cafaggi and Hans-W. Micklitz (eds), New Frontiers of Consumer Protection: the Interplay Between Private and Public Enforcement (Intersentia 2009).

${ }^{244}$ An example of an ex ante mechanism is the Food and Drugs Administration process of approving a drug for consumption. See Jordan Paradise and others, 'Evaluating Oversight of Human Drugs and Medical Devices: a Case Study of the FDA and Implications for Nanobiotechnology' (2009) 37 Journal of Law, Medicine \& Ethics 598. 
that can be deployed after the harm took place. ${ }^{245}$ Since a regulatory regime will be embedded in a given social reality, the surrounding environment must be analyzed so that the best design may be drafted. In other words, the regulatory process has to take into account the institutional background available to assess the possible success of a regulatory scheme. ${ }^{246}$

When designing regulatory systems it is necessary to identify at each stage of the process the potential regulators, regulatees, adressees and enforcers of the rules. Rulemaking may be seen as illegitimate if it is done by private actors, ${ }^{247}$ but on other occasions, the involvement of private actors might be the only solution for a specific problem, even if in the public interest. 248

The same is true for regulatory enforcement. If compliance control will be made before an action is taken, such as before the authorization of the issuance of a security, the regulators should guarantee that institutions overseeing the process have the necessary skills to do so, otherwise the regulatory scheme may overburden the economy with unnecessary costs and difficulty in compliance. ${ }^{249}$ On the other hand, if the enforcement mechanisms are engaged ex post, for example through lawsuits, it is important to survey the environment to see if the decision makers are independent and if claimants will have sufficient incentives to pursue their claims.

245 The classic example is tort law.

${ }^{246}$ See Issacharoff and Samuel (n 243).

247 One example that has been widely discussed is the International Accounting Standards Board, the standard setter for accounting standards that has taken a major role in the world today. For a discussion on the legitimacy of private accounting standard setting boards, see Eve Chiapello and Karim Medjad, 'An Unprecedent Privatisation of Mandatory Standard-Setting: the Case of European Accounting Policy' (2009) 20 Critical Perspectives on Accounting 448 Andreas M. Fleckner, 'FASB and IASB: Dependence Despite Independence' (2008) 3 Virginia Law \& Business Review 275.

248 This is the case with the international accounting standards regime. Due to the lack of a proper organization in place to create accounting standards that had sufficient quality to be used across countries in the European Union while at the same time capable of accommodating different political interests, the IASB, a private organization in existence since the 1970s, was chosen to perform this role. See Tiago Andreotti, 'The Legitimacy and Accountability of the IASB as an International Standard Setter' in Fabrizio Cafaggi and Geoffrey Miller (eds), Private Regulation and Enforcement in Financial Institutions (Edward Elgar 2013).

${ }^{249}$ One example of unnecessary costs created by badly designed regulation and lack of close scrutiny by regulators is the effects that Regulation NMS had on the American financial market by incentivizing highfrequency trading. See Michael Lewis, Flash Boys: a Wall Street revolt (W.W. Norton \& Company Inc. 2014). 


\section{B. The mix of regulatory mechanisms in securities regulation}

The regulatory system for securities is a diverse mix of the public and private sphere, tending more to the public side. Usually the rules of the game are set by government agencies created specifically for the task of regulating and supervising securities markets; with the rule-making power they also receive extensive enforcement powers. ${ }^{250}$

Within their supervisory domain, they may also delegate some of their functions to private institutions. For example, rule-making authority regarding accounting standards - the language of financial disclosure - has been long delegated by the SEC in the United States to private standard setting bodies. ${ }^{251}$

At the same time, private regulatory entities are allowed to co-exist with securities and exchange commissions, playing an important role in drafting and applying rules that are in compliance with the objectives of the underlying regulatory regime. ${ }^{252}$ In the securities markets, two important examples are the organized markets, such as the NYSE and Bovespa, and private regulatory authorities, such as FINRA. Organized exchanges require compliance with rules of disclosure and corporate governance to admit companies to list, while private regulatory authorities regulate the behavior of the members of the profession, such as brokers and dealers, through delegated government power.

These private entities also have their own enforcement mechanisms; they can deny access to the regime, which in most cases means denial of market access, and they can also apply various penalties. There is a caveat though: these regulators can only

\footnotetext{
250 The penalties range from imposing fines to the prohibition of exercising specific functions that may fall within the supervision of the agency.

${ }^{251}$ For an overview of the development of the accounting profession in the United States, see Stephen A. Zeff, 'How the U.S. Accounting Profession got Where it is Today: Part I' (2003) 17 Accounting Horizons 189-205 Stephen A. Zeff, 'How the U.S. Accounting Profession got Where it is Today: Part II' (2003) 17 Accounting Horizons 267-86.

252 This type of a two-tiered regulatory structured, where the government oversees a private regulatory body, is known as meta-regulation. Cary Coglianese and Evan Mendelson, 'Meta-Regulation and SelfRegulation' in Robert Baldwin, Martin Cave and Martin Lodge (eds), The Oxford Handbook of Regulation (Oxford University Press 2010) 147-51.
} 
enforce rules in respect of their members because their authority arises out of the membership of the regulatee in the regulatory scheme.

The last set of enforcement mechanisms is more direct. The investor that is harmed due to a breach of a rule in the regime may start legal proceedings to obtain redress, as long as there are mechanisms available. These proceedings can either be judicial, in a court of law, or be initiated through other means, such as arbitration; this depends on the contractual or corporate scheme governing the relationship. The next section shows why private enforcement is important to achieve the goals of securities regulation.

\section{The Importance of Private Enforcement in Securities Regulation}

As mentioned above, the mere presence of substantive rules is not sufficient for them to accrue any value, since a proper system of enforcement is necessary for welldesigned black-letter law to be deployed. ${ }^{253}$ The architecture of the enforcement mechanisms of a given regime is a policy-choice that has to be made. To this extent, both the public and private enforcement of securities regulation play an important role in the securities regulation system..$^{254}$

In the securities context, public enforcers are government agencies that are established with clear objectives to promote market efficiency and investor protection and are given the power to advert, fine or even suspend market actors from engaging in their professional roles as they relate to securities transactions. In some specific systems, they are given the power to sue in court, shifting the decision-making process of the enforcement mechanisms to an impartial judge. Private enforcers are the persons that

\footnotetext{
${ }^{253}$ For an overview on the impact of enforcement in securities regulation see Luzi Hail and Christian Leuz, 'International Differences in the Cost of Equity Capital: Do Legal Institutions and Securities Regulation Matter?' (2006) 44 Journal of Accounting Research 485; John C. Coffee, 'Law and the Market: the Impact of Enforcement' (2007) 156 University of Pennsylvania Law Review 229 (Professor Coffee hypothesizes that the difference in enforcement may explain the difference in share value increase when cross-listed firms in the US and the UK are compared).

${ }^{254}$ Compare Rafael LaPorta, Florencio Lopez-de-Silanes and Andrei Shleifer, 'What Works in Securities Law?' (2006) 61 The Journal of Finance 1 (arguing that 'securities law matter because they facilitate private contracting rather than provide for public regulatory enforcement') and Howell E. Jackson and Mark J. Roe, Public and Private Enforcement of Securities Laws: Resource-Based Evidence (Harvard Law School 2009) (demonstrating that there is a strong association between outcomes in securities regulation and public enforcement, when it is measured by resources).
} 
have been defrauded or otherwise have a claim against an issuer or a financial intermediary in respect of a harm inflicted upon them while transacting securities, and who can decide, given the incentives for the dispute resolution system, to sue, with the option also of submitting their claim to an independent third party.

Both kinds of enforcement constitute parts of a regulatory system that tries to achieve market efficiency in capital markets and to create a just environment for trading. In addition to the economic aspects that securities regulation and its enforcement may bring, there is also another aspect that must be considered when securities regulation is discussed, which is investor protection.

The basic differences between public and private enforcement can be summarized along the following lines: ${ }^{255}$ while public enforcers obtain a salary to perform their duties, ${ }^{256}$ private enforcers are remunerated either for the specific task at hand or through the spoils of their efforts. ${ }^{257}$ Another consideration relates to the goals of enforcement: public seeks deterrence; while private aims at compensation. ${ }^{258}$ This is a simplified portrayal of the matter, as there are, for example, public enforcers that receive remuneration for their efforts 259 and private enforcers that work for the public good, not expecting an economic advantage from their work; ${ }^{260}$ notwtstanding, this distinction is

255 This section has benefited from the literature review made in Margaret H. Lemos and Max Minzner, 'ForProfit Public Enforcement' (2014) 127 Harvard Law Review 853, 858-63.

256 ('[...] public attorneys work for the public and are paid a salary to do so. The amount of time they invest in an issue, the amount of sanction they recover, or the amount of harm they deter, has no bearing on their fee. Their priorities, the uses of their billable hours, are generally determined by politics, not money'.) Rubenstein 2139 (n 85).

257 On this second case, they can either have their interests aligned to the person who will be compensated, or they can be looking for their own interest by acting as bounty hunters with no compensatory interest where this is allowed. See Martin H. Redish, 'Class Actions and the Democratic Difficulty: rethinking the intersection of private litigation and public goals' [2003] 2003 University of Chicago Legal Forum 71, 9091.

258 Rubenstein 2140-42 (n 85).

259 Professors Lemos and Minzer explain that until the $20^{\text {th }}$ century the remuneration of public officials through what they obtained through their efforts was common in the U.S., such as with tax collectors that were allowed to retain some of the taxes they collected. Even though this incentive set-up was mostly abandoned by the turn of the $20^{\text {th }}$ century, it has been returning since public enforcement started to be used to compensate victims. Lemos and Minzner 861-63 (n 255).

260 In Professor's Coffee terminology, these are the ideological private attorney generals, who are financed by foundations or membership donations, being controlled by the social and political groups that they serve. John C. Coffee, 'Rescuing the Private Attorney General: Why the Model of the Lawyer as a Bounty Hunter is not Working' (1983) 42 Maryland Law Review 215, 235. 
the basic starting point from which the 'pure' public and private types of enforcement differ.

As the state is the source of authority for legal rules, enforcement is in its own interest since noncompliance would be considered a failure of the legal system, and consequently of the state itself. This is especially important in areas where the legal rules purport to regulate behavior in the public interest; these are often the types of rules that need justification, as explained in chapter 2. ${ }^{261}$ Public enforcement however is not without its shortcomings. At the outset, the creation and maintenance of an enforcement machine requires the expenditure of a substantial amount of resources, which could be used in more productive governmental activities. Then there are the problems to which the public enforcement machine is subject, creating the possibility of inadequate enforcement: on one hand, bribes, ${ }^{262}$ political influence, ${ }^{263}$ capture, ${ }^{264}$ the individual interest of the enforcer in moving to the private sector, ${ }^{265}$ shirking ${ }^{266}$ and on the other, overreaction due to scandals 267.

${ }^{261}$ See Chapter II, Section 3.B.

262 There are three important aspects to the mechanics of a bribe: 1) honesty: a person who is subject to a fine is willing to pay the enforcer a sum up to the value of that fine to forego enforcement. The enforcer, acting in his self-interest, may accept the bribe if the perceived profit from it is higher than the perceived cost of the action; 2) structure of incentives: both enforcers gain in enforcing law and violators gain in violating the law, but the variation in the gain of violators is higher than the gain of enforcers, consequently giving such violators more resources than enforcers, giving them more power to bribe; 3) temporal pattern of violations: repetitive violation is more likely to create situations where the enforcer can be bribed. See Gary S. Becker and George J. Stigler, 'Law Enforcement, Malfeasance, and Compensation of Enforcers' (1974) 3 Journal of Legal Studies 1, 3-5.

263 ('Politicians may undermine enforcement efforts by replacing key personnel or cutting budgets, and limited resources may prevent public enforcers from uncovering and pursuing violations') Lemos and Minzner 859 (n 255).

${ }^{264}$ For a general overview of the literature, see Ernesto Dal Bó, 'Regulatory Capture: a review' (2006) 22 Oxford Review of Economic Policy 203; Rachel E. Barkow, 'Insulating Agencies: avoiding capture through institutional desing' (2010) 89 Texas Law Review 15.

265 This is known as the revolving door phenomenon, where the individual is interested in being part of the public enforcement agency only to gain expertise to move to the private industry later on. See Revolving Door Working Group, A Matter of Trust: how the revolving door undermines public confidence in government - and what to do about it (2005).

266 On the question of individual incentives for public employees, see Lemos and Minzner 886-95 (n 255).

${ }^{267}$ See A. C. Pritchard, 'The SEC at 70: time for retirement? ' (2005) 80 Notre Dame Law Review 1073, 107883. 
Private enforcement, on the other hand is mainly a self-interested activity; ${ }^{268}$ as long as the expected benefits outweigh the costs of litigation, private parties will have an incentive to engage in enforcement. The risk with private enforcement is overenforcement, which is created when the rules allow a plaintiff to recoup more from the procedure than the harm actually suffered; ${ }^{269}$ this is a problem that is created through institutionally-designed incentives and which can be controlled in the same way.

The other problem with private enforcement, if it were to be used exclusively, is that enforcement will only be executed in the case that expected benefits outweigh litigation costs. From a social point of view, it is not always true that a lawsuit that costs more than the dollar amount at stake is undesirable, as it may create deterrence effects that are more beneficial than the amount that will be spent on it. ${ }^{270}$

Therefore, from this initial discussion, it can be implied that private enforcement is more adequate when there are incentives for plaintiffs to pursue it. If this is the case, in situations where a private party is harmed and the conduct does not constitute something that should be considered a crime, ${ }^{271}$ the best approach to enforcement would be to leave it to private parties. This is justified due to the fact that the state would not have to invest in an enforcement structure for these cases, saving resources for other activities and avoiding the problems that are susceptible in public enforcement operations. In addition, private enforcers also are free from the bureaucratic structure of government, being able to move more quickly than the public counterpart. ${ }^{272}$

On the other hand, public enforcement is justified in two situations: a) when, even though there is a social benefit in enforcing a particular rule due to its deterrence effects, the cost of the lawsuit for the private party is higher than its expected benefit and b)

\footnotetext{
268 ('...private parties are not usually concerned, or are not exclusively concerned, with the social purposes of litigation, whatever may constitute these purposes; private parties are primarily concerned with their selfish benefits from litigation.') Steven Shavell, 'The Fundamental Divergence Between the Private and the Social Motive to Use the Legal System' (1997) 26 Journal of Legal Studies 575, 579.

269 William M. Landes and Richard A. Posner, 'The Private Enforcement of Law' (1975) 4 Journal of Legal Studies $1,15$.

270 Shavell 584-85 (n 268).

271 Which varies depending on the cultural values of the specific jurisdiction.

${ }^{272}$ See Coffee, 'Rescuing the Private Attorney General: Why the Model of the Lawyer as a Bounty Hunter is not Working' 226 (n 260).
} 
where the prohibited conduct is victimless, as there will be no private party interested in enforcing the rules. ${ }^{273}$

This is a general approach that can be applicable in any area when the deterrence function of litigation is at stake - to minimize costs, it is interesting to design the system in such a way that public enforcement will be used as little as possible, allowing private parties to seize the enforcement function when they have the incentives to do so, leaving public enforcement for cases when such incentives are absent.

The purpose of securities law is twofold: namely, efficient markets and investor protection, ${ }^{274}$ where the latter is also important to economic efficiency. ${ }^{275}$ Deterrence therefore is not the only objective, as a system needs to be in place for investors to be protected so that they can be compensated in case they are harmed by behavior that violates securities laws.

Therefore, as securities laws have a dual purpose of deterrence and compensation, the claim that private enforcement should be the first step of designing an enforcement regime becomes even stronger; an exclusive public enforcement system for compensation would be at a high risk of capture by the industry, especially in financial markets where there often is a lot of money at stake. For proper investor protection and the creation of market confidence, the best approach is to allow a regime for private enforcers, where enforcers are more likely to have their interest aligned with those of the plaintiffs. With the compensation regime set, deterrence objectives should then be engaged and other enforcement mechanisms created to calibrate the system, as a non-calibrated enforcement system may lead to either under-deterrence, which may breed abuse and trigger many of the social costs of inefficient markets discussed above, or it may cause

\footnotetext{
273 See Becker and Stigler 4-5 (n 262).

274 'The mission of the U.S. Securities and Exchange Commission is to protect investors, maintain fair, orderly, and efficient markets, and facilitate capital formation'. SEC, 'The Investor's Advocate' (SEC) <http://www.sec.gov/about/whatwedo.shtml> accessed 11 April 2012 See also CVM, 'The Commission' (CVM) <http://www.cvm.gov.br/ingl/indexing.asp> accessed 7 July 2014 ('The Law that instituted the Comissão de Valores Mobiliários - CVM established that it should observe the following objectives: to assure the proper functioning of the exchange and over-the-counter markets; to protect all securities holders against fraudulent issues and illegal actions ...')

275 For an overview on the discussion of investor protection and economic efficiency, see Andromachi Georgosouli, 'The Debate over the Economic Rationale for Investor Protection Regulation: a Critical Appraisal' (2007) 15 Journal of Financial Regulation and Compliance 236.
} 
over-deterrence, creating other kinds of costs that are unnecessary, consequently undermining economic efficiency. ${ }^{276}$

The point I make for private enforcement and investor protection is an important one for this thesis. Its central aspect is to create dispute resolution systems where private enforcement can be effectively deployed transnationally, enhancing the scope of protection of securities laws - be they national or foreign - to the investors who wish to participate in foreign markets, or in transactions with foreign securities aspects.

\section{Concluding Remarks}

Theoretical and empirical studies have shown that securities regulation does have a role in enhancing economic efficiency in securities transactions, whether through diminishing transaction costs for the allocation of capital or by giving investors confidence that the market will not be defrauded, thus avoiding the 'lemons problem'

On the enforcement side, the best approach is to have a private redress system as a starting point, as this avoids the unnecessary costs of creating and maintaining public enforcers and empowers investors to act in their own self-interest, helping to build their confidence in the market.

${ }^{276}$ For a general overview on the potential problems of multiple enforcers, see Amanda M. Rose, 'The Multienforcer Approach to Securities Fraud Deterrence: a Critical Analysis' (2010) 158 University of Pennsylvania Law Review 2173. 


\section{Chapter V - The Liability Regime for Securities Disputes}

Legal disputes arise out of the breach of a right. Recovery is only possible if a party that owes a legal obligation to another fails to comply with this obligation. Rules on liability establish the standard that should be complied with and are an essential part of any legal framework that purports to regulate conduct, guarantee rights and fix market failures. It is composed both by the basis used by plaintiffs to present their argument to a court as well as the defenses available to defendants to avoid the payment of damages.

Securities transactions are executed in a fairly similar fashion across different jurisdictions; yet depending on the legal relationship that is at stake, the standards of conduct may differ, as might the liability regime available. Much of the design of a liability system for transactions with securities depends on the characteristics chosen to define the concept, yet there is no universal definition of what a security is, even though the concept is similar in every jurisdiction. The exact legal contours of the definition are, of course, set out within each different legal system. The American definition is quite broad, ranging from the more commonly known legal category of a company's share to the more complicated investment contract, encompassing all sorts of derivatives in between. ${ }^{277}$ Securities law is applicable if there is a transaction involving a security where there are no exemptions either to the security being transacted or to the transaction itself.

The backbone of securities law and the liability regimes involved at every step of securities transactions are based on regulating information asymmetry and diminishing

\footnotetext{
277 The exact language is: 'the term "security" means any note, stock, treasury stock, security future, bond, debenture, evidence of indebtedness, certificate of interest or participation in any profit-sharing agreement, collateral-trust certificate, preorganization certificate or subscription, transferable share, investment contract, voting-trust certificate, certificate of deposit for a security, fractional undivided interest in oil, gas, or other mineral rights, any put, call, straddle, option, or privilege on any security, certificate of deposit, or group or index of securities (including any interest therein or based on the value thereof), or any put, call, straddle, option, or privilege entered into on a national securities exchange relating to foreign currency, or, in general, any interest or instrument commonly known as a 'security', or any certificate of interest or participation in, temporary or interim certificate for, receipt for, guarantee of, or warrant or right to subscribe to or purchase, any of the foregoing.' Securities Act of 1933 s 2(a)(1). Security-based swap agreements do not fall within the definition of a 'security'. Securities Act of $1933 \mathrm{~s} 2 \mathrm{~A}$.
} 
the costs thereof, from the issuance of shares to the certification of financial statements by auditors.

The objective of this chapter is to identify and classify the types of disputes arising out of securities transactions and to demonstrate, through a brief analysis, that the standards of conduct in different jurisdictions may differ depending on the type of dispute that is at stake and on the relevant liability regime. Moreover, the identification of the different types of disputes is relevant because the available dispute resolution mechanisms are closely related to the specific category of dispute.

Therefore, the main question to be answered in this chapter is 'what are the types of disputes arising out of securities transactions?' To do so, this chapter explains (1) the securities commercialization process and its relationship to the disputes; identifies (2) the legal framework for securities liability on disclosure; (3) the legal framework for financial intermediaries on securities transactions; (4) the legal framework for informational gatekeepers and (5) analyses the specific aspects of each type of dispute.

\section{Transacting Securities and Disputes}

To understand securities disputes, it is important to firstly understand the securities issuance process and the role that each actor plays in it. The basis for securities liability is the placement of securities in the market and the ongoing regulatory disclosure duties after securities are placed and remain in commerce, and the commercialization efforts by intermediaries.

\section{A. Issuing Securities}

Securities are issued and placed in the 'primary market' and traded in the 'secondary market'. There are many reasons for issuing securities, but the main one is to raise capital in order to finance a business. There is a great deal of effort to market the securities, find buyers and price them before the initial offering. This is a role that is assigned to an underwriter, that is, a financial services provider that helps the issuer with the placement of securities in the market. There are two ways in which the underwriter performs this function: the firm commitment and the 'best efforts' method. In the first case, the underwriter assumes the risk of the issuance by committing to buy a percentage 
of the shares issued at an agreed price, while in the second, the risk does not shift and the underwriter maintains the right to return any unsold shares.

Before the securities are put on the market, it is common for the regulatory agency of the country in which the securities will be issued or the law itself, to require audited financial statements from the issuer. ${ }^{278}$ These statements are signed by the relevant issuer's officers and then certified by auditors, who are accountants that are members of a regulatory body that authorizes them to perform audits. 279

Another requirement is the filing of a registration statement and the distribution of prospectuses before the securities are placed in the market. These documents have to contain all the relevant information about the issuance and the company to allow investors to make informed decisions. The responsibility for the information's veracity falls both with the issuer and the underwriter. Credit rating agencies also play a role by evaluating the risk of a given security.

Finally, after the legal requirements have been complied with, the underwriter can place the securities in the market, which can be done either through qualified investors or via the general public. ${ }^{280}$ There are direct selling efforts made by banks and securities brokers; they can also incur liability depending on the information they provide to their customers.

After the securities are placed, they can be traded openly through exchanges or on the over-the-counter markets. When the securities are traded on public markets, ongoing disclosures about the securities and the financial health of the company that has issued them are often required; this is a duty that falls on the issuer. At the same time, auditing firms certify financial statements and CRAs continue to evaluate the riskiness of certain securities and/or the companies issuing them.

\footnotetext{
278 E.g. Financial Audit Law Recast (Spain), first additional disposition.

279 E.g. Sarbanes-Oxley Act of 2002, s 102.

280 The legal requirements vary depending on which process is chosen.
} 
The commercialization of securities is made through financial intermediaries, banks, brokers and dealers, who engage in contractual relationships with investors to sell the securities and to provide financial services in relation to them.

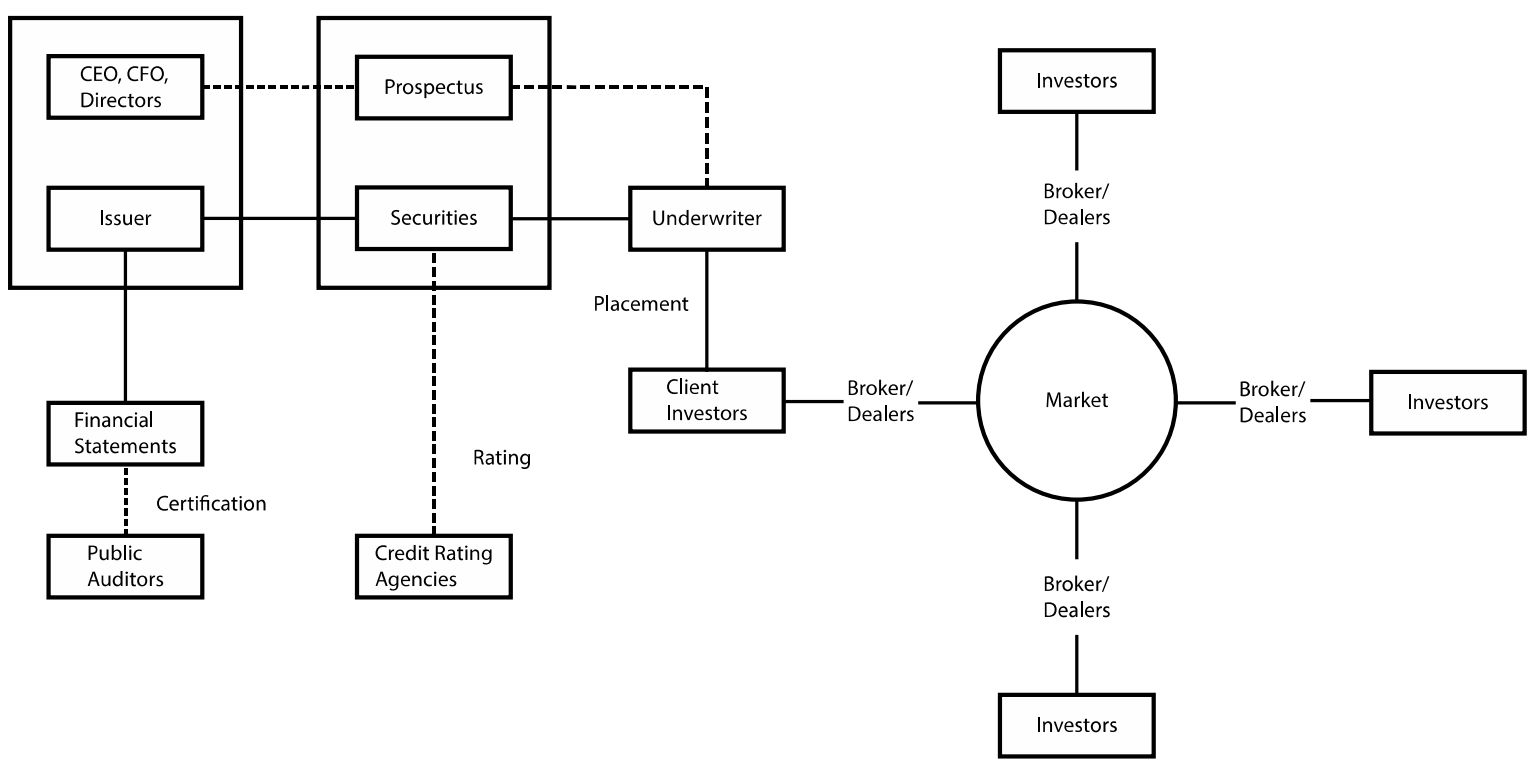

Figure 1: Issuance Process

\section{B. Types of Disputes}

From this account of how securities are issued and traded, it is possible to identify three main categories of disputes arising out of securities transactions, which are dependent on the relationship that the investor has with the party from whom recovery is sought.

Some legal relationships are clear; the investor who buys securities through a financial intermediary has a contract with him, creating a direct relationship between the parties. Other relationships are not so clear; this includes the investor who relied on a credit rating agency's rating to buy securities.

In any event, disputes arising out of securities transactions can be grouped into three categories: issuer - investor, financial intermediary - investor and informational intermediary - investor. While each type of dispute is not exclusive for each particular basis of liability, for example, financial intermediaries may fall within both disclosure liability as well as contractual liability, this categorization of disputes is helpful in order 
to analyze the dispute resolution systems available to each of them, as the duties on different regulatory systems are usually divided in this manner.

\section{Transacting Transnationally}

\section{a. General}

To establish the transnational character of securities transactions, it is necessary to start with the understanding that markets are, at least legally, tied to certain national regulatory schemes. There is no such thing as a global market in the legal world; what exist are local markets regulated by specific jurisdictions.

A Brazilian company that wishes to raise money in the United States has to register its securities with the SEC and place them through financial intermediaries that are registered to do business in the United States. Selling efforts made to the U.S. market through a Brazilian financial intermediary without registration would be illegal under U.S. Law; the same is true the other way around. ${ }^{281}$

There are two consequences of this situation: firstly, legal access to a market requires registration and compliance with local market rules, both regarding securities and financial intermediaries. Secondly, disputes with financial intermediaries, when the relationship has been started at the initiative of the financial intermediary, will be national since the financial intermediary will usually be required to have a local presence. $^{282}$

Even though the relationship between financial intermediaries and investors will be mainly national, a legal transnational transaction with a financial intermediary is also possible when the investor is the one going after a foreign financial intermediary to obtain access to different markets. ${ }^{283}$

281 Transactions regarding the general public. See Securities Act of 1933, s 5; Securities Exchange Act of 1934, s 15(a)(1); Investment Advisers Act 1940, s 203(a); Law 6.385/76 (Brazil), art. 16.

282 This affirmation does not apply to the EU area due to the passport scheme that exists there.

283 For example, Charles Schwab has a service for international investors to open a brokerage account in the U.S. and invest directly in the U.S. Markets. See Charles Schwab, 'Open an Account' <http://international.schwab.com/public/international/nn/open_an_account?country=BR.> accessed 7 July 2014. 
The securities on the other hand, while they have to be registered nationally, do not have to be from a company incorporated nationally. National Depositary shares, such as American Depositary Shares or Brazilian Depositary Shares are a common occurrence, as are cross-listed companies. The transnational aspect and the problems arising from it become evident; while the company issuing securities is being regulated in a given jurisdiction, its assets can only be found in another. As such, it may be difficult for the investor to solve a dispute effectively with a company if an event creating liability occurs due to the lack of effective transnational dispute resolution mechanisms.

In these cases, credit rating agencies and auditor liability may also present the same type of problem; for example, in case an American investor relies on a rating issued by a Brazilian CRA of a Brazilian company that has its shares traded on a U.S. stock exchange. Absent an effective dispute resolution system, the CRA becomes immune towards foreign investors. ${ }^{284}$

Therefore, despite the national character of securities regulation, these examples show that there are situations in which transnational disputes on securities transactions may occur.

b. EU

The European landscape of transnational securities is slightly different from the one presented above. The European Union has a passport mechanism, ${ }^{285}$ both regarding prospectuses and financial intermediaries, which make transnational securities transactions easier. Regarding the prospectus, its approval is required by only one of the Member States, being automatically valid within all other Member States. It is only required that the competent authority of the host Member State is notified. ${ }^{286}$ Financial

\footnotetext{
${ }^{284}$ They might be immune as a matter of law and have no, or at least, a very low level of liability, in certain jurisdictions. For a comparative perspective of Credit Rating Agencies liability in different jurisdictions, see Alessandro Scarso, 'The Liability of Credit Rating Agencies in a Comparative Perspective' (2013) 4 Journal of European Tort Law 163.

285 The passport mechanism is based on the mutual recognition principle established in the Cassis de Dijon judgment (Case 120/78 Rewe-Zentral AG v Bundesmonopolverwaltung für Branntwein (Cassis de Dijon) [1979] ECR 649), which comprises the mechanism of the single passport and home state supervision. See Hallgrímur Ásgeirsson, 'Integration of European Securities Markets' [2004] 2004 Monetary Bulletin - The Central Bank of Iceland 50, 51.
}

${ }^{286}$ Directive 2003/71/EC, art. 17. 
intermediaries, when authorized in their home Member State, can provided services, as long as they fall within the scope of the services that they have been authorized to provide in their home state, within other Member States either directly, by using tied agents or by establishing a branch. 287

This mechanism is based on the more general goal of the EU, that is the construction of an internal market, ${ }^{288}$ which for the purposes of this discussion is strongly tied to the right of establishment, ${ }^{289}$ the freedom to provide services ${ }^{290}$ and the free movement of capital. ${ }^{291}$ Such passport regime increases the likelihood of transnational securities transactions as it relieves the burden of registration in every single jurisdiction, whether for the securities or for the financial intermediary, decreasing the costs of foreign market operation and capital-raising.

The next sections will loosely follow the distinction among the types of disputes. The first section will address issuer liability, which is mainly related to disclosure liability, even though the standards that are articulated may also be applicable to the other players who provide information. The following two sections analyze the financial intermediaries dispute, where there is a contractual relationship between the parties, and the informational gatekeeper dispute, in respect of which liability is based mainly on a tort or securities regulation related standard, where there are no direct links between the investor and the informational gatekeeper.

\section{Legal Framework for Securities Liability - Issuers}

As the basis of securities regulation is information asymmetry, the main duty that persons involved with the issuance and distribution of securities have is the duty of information disclosure. Securities regulation imposes duties of information, both at the issuance stage of the process as well as at periodic stages thereafter, that is, information

\footnotetext{
287 Directive 2004/39/EC, arts. 31 and 32.

288 TEU, art. 3(3) and TFEU, art. 26.

289 TFEU, art. 49.

290 TFEU, art. 56.

291 TFEU, art. 63(1).
} 
on the health of the company whose securities are being traded on the market. The breach of these duties creates a right for the person who has been harmed by false or misleading information or by an omission made by those obliged to provide such information.

The breadth of this private right of action and the extent to which it can be effective for investors to recover is dependent not only on the substantive rules of conduct, but also on the procedural requirements that have to be met for a claim to prevail. While the purpose of this section is mainly to identify the standards of conduct of the jurisdictions under study, some of the procedural developments, especially in the United States system for securities disputes, must be considered because they have evolved together with the substantive reforms on the securities regulation system and are an essential part of the liability regime.

\section{A. The United States}

Securities regulation at the federal level in the U.S. appeared in a moment where there was great concern and frustration with the economic depression, just after the 1929 crash. ${ }^{292}$ The Securities Act of 1933 was designed to avoid the 'caveat emptor' logic for selling securities by imposing extensive duties of truthfulness on issuers and on persons related to the issuance of securities, while the Securities and Exchange Act of 1934 focused on the regulation of speculative trading. ${ }^{293}$

Contrary to the civil law countries under analysis, the liability regime from securities transactions in the U.S. is heavily informed by the provisions of its securities laws. ${ }^{294}$ Most of the securities claims arise under the concept of misrepresentation and securities fraud, mainly under Rule $10 \mathrm{~b}-5 .{ }^{295}$ In 2013 84\% of class action lawsuits in securities litigation presented a Rule $10 \mathrm{~b}-5$ claim. ${ }^{296}$

\footnotetext{
292 Burk 1012 (n 112).

293 Ibid 1012-13.

294 Even though securities regulation standards also play a role in liability in civil law countries, the backbone of private enforcement relies more on general contractual and tort standards.

29517 C.F.R. $§ 240.10$ b-5 (2013).

296 Cornerstone Research, Securities Class Action Filings - 2013 in Review (2013).
} 
Two other important causes of action for private securities litigation in the United States, but not as nearly relevant as the $10 \mathrm{~b}-5$ claims, are Section 11 and Section 12 of the Securities Act of 1933. Section 11 claims were present in $9 \%$ of the filings in 2011, while the 12 (2) variety of Section 12 was present in only $7 \% .^{297}$

\section{a. The Securities Act of 1933}

\section{The Securities Act of $1933 \S 11$ Standard}

A security, unless exempted under Section 3(a) of the Securities Act of 1933 § 3(a), must be registered with the SEC. A transaction of, or an attempt to transact, an unregistered security is expressly prohibited by Section 5 of the Securities Act of 1933, unless the transaction itself is also exempted by Section 4 of the Securities Act of $1933 .{ }^{298}$

The information that is required in a registration statement is extensive, including a business description, an outline of property owned, a description of the material legal proceedings that the company is facing, financial information, and management structure, amongst other information. ${ }^{299}$ If, by its effective date, ${ }^{300}$ any information in the registration statement is untrue regarding a material fact or if it is misleading by omission, the buyer of the security has a private right to sue under Section 11 of the Securities Act of $1933 .^{301}$ In general, proving reliance on the statement is not necessary, it being only necessary that the plaintiff proves the existence of the falsity or of the omission made. ${ }^{302}$

297 Ibid .

298 See also Rule 144, 17 C.F.R. $§ 230.144$ (2013), Rule 144A, 17 C.F.R. $\S 230.144$ a (2013), Regulation D (Rules Governing the Limited Offer and Sale of Securities Without Registration Under the Securities Act of 1933), 17 C.F.R. $\S \S 230.501$ - 230.506 (2013) and Regulation S (Rules Governing Offers and Sales Made Outside the United States Without Registration Under the Securities Act of 1933), 17 C.F.R. §§ 230.901230.905 (2013).

299 See Regulation S-K, 17 C.F.R. § 229 (2013).

300 The effective date of a registration statement is deemed to be 20 days after it is filed and has to be calculated according to 17 C.F.R. $§ 230.459$ (2013).

${ }^{301}$ For the materiality requirement to be fulfilled, it is necessary that 'there must be a substantial likelihood that the disclosure of the omitted fact would have been viewed by the reasonable investor as having significantly altered the 'total mix' of information made available.' Basic Inc. v. Levinson, 485 U.S. 224, 231232 (1988) (quoting TSC Indus., Inc. v. Northway, Inc., 426 U.S. 438, 449 (1976)).

302 Reliance is presumed under this Section if the purchase is made before the first 12-month earnings report covering a period of 12 months after the registration's effective date (Securities Act of 1933 s 11(a)). See also Herman \& MacLean v. Huddleston, 459 U.S. 375, 382 (1983)('if a plaintiff purchased a security 
One caveat is that if the pleading is 'sound in fraud', it has to satisfy the heightened pleading standard of Section 9(b) of the Federal Rules of Civil Procedure, requiring the party to plead with particularity the circumstances consisting of fraud or mistake. ${ }^{303}$

This is a cause of action linked with the issuance of securities, and it creates a limited class of possible plaintiffs; only those who made the purchase of a primary offering are allowed to sue under Section 11(a). ${ }^{304}$

The statute is generous in lining up defendants: the issuer, everyone who signed the registration statement, directors at the time of the filing, persons responsible for certifying statements in the filing and the underwriters can all be sued. ${ }^{305}$ With the exception of outside directors, who are proportionally liable to their statements, ${ }^{306}$ all defendants are jointly and severally liable. ${ }^{307}$

While the statute allows for various different defendants, it also provides them with various defenses. The first one is knowledge of the untrue or misleading statement by the plaintiff. If the defendant proves that the plaintiff knew that the statement was untrue or misleading, no liability can attach. ${ }^{308}$

The second defense is resignation. Non-issuers are not liable under Section 11 of the Securities Act of 1933 if, before the effective date of the part of the registration statement in which they are supposedly liable, they had resigned from office or had taken steps to do so and had also advised the Commission and the issuer that they would not be responsible for that part of the statement. 309

issued pursuant to a registration statement, he need only show a material misstatement or omission to establish his prima facie case').

303 See also Todd R. David, Jessica P. Corley and Ambreen A. Delawalla, 'Heightened Pleading Requirements, Due Diligence, Reliance, Loss Causation, and Truth-on-the-Market - Available Defenses to Claims under Sections 11 and 12 of the Securities Act of 1933' (2009) 11 Transactions Tennessee Journal of Business Law 53, 61-63.

304 See APA Excelsior III L.P v. Premiere Technologies Inc., 476 F.3d 1261, 1276 (11 ${ }^{\text {th }}$ Cir. 2007).

305 Securities Act of 1933, s 11(a)(1)-(a)(5).

${ }^{306}$ Securities Act of 1933, s 11(f)(2); see also Securities Exchange Act of 1934 s 21D(f).

307 Securities Act of 1933, s 11(f)(1).

308 Securities Act of 1933, s 11(a).

${ }^{309}$ Securities Act of 1933, s 11(b)(1). 
The third defense is a lack of knowledge regarding the part of the registration statement to which the person is liable coupled with the person's resignation. If the registration statement becomes effective, liability can only be avoided if, by discovering the statement (or lack thereof), the person advises the SEC and the issuer and take the steps to resign, while also giving public notice that the statement became effective without his knowledge. ${ }^{310}$

The last defense that is clearly provided for in the statute is reasonable belief. The defendant has to prove that, after a reasonable investigation, there were reasonable grounds to believe, and the defendant in fact believed, that the statements were true and not misleading, or in case of an expert, that his opinion in the statement was not fairly represented. 311

Besides these statutory defenses, there are also other important defenses created in the judicial context. Among them are the impossibility of reliance and the lack of loss causation. Reliance on the registration statement, for the purposes of a plaintiff's claim in a class action, is presumed. If, from the facts, it is clear that plaintiffs could not have relied on the statements because they had committed themselves to the transaction before the filing of the registration statement, liability does not arise. ${ }^{312}$ The other defense comes from the logical link between the misleading or false statement and the harm suffered. If the defendants prove that there was no loss causation, liability does not attach. ${ }^{313}$

Damages under this cause of action are the price paid for the security minus (a) its value at the time of the suit; (b) the price for which the securities were sold before the suit; or (c) the price for which it should have been disposed after the suit but before judgment, but only if such damages are less than the difference of the price paid for the

\footnotetext{
310 Securities Act of 1933, s 11(b)(2).

311 Securities Act of 1933, s 11(b)(3).

312 See APA Excelsior III L.P. v Premiere Technologies Inc. (n 304) 1277 ('In sum, we hold that the Section 11 presumption of reliance does not apply in the limited and narrow situation where sophisticated investors participating in an arms-length corporate merger make a legally binding investment commitment months before the filing of a defective registration statement'). For an extensive review on the recent judicial developments on Section 11, see Marc Steinberg and Brent Kirby, "The Assault on Section 11 of the Securities Act: a Study in Judicial Activism' (2010) 63 Rutgers Law Review 1.
}

${ }^{313}$ See In re Merck \& Co., Inc. Securities Litigation 432 F.3d 261, 274 (3 ${ }^{\text {rd }}$ Cir. 2005). 
securities (in which case it shall not be in excess of the price offered to the public) and their price at the time of the suit. ${ }^{314}$

In sum, Section 11 of the Securities Act is a straightforward provision: if there is a registration statement with false or misleading information when shares are sold to the public and there is a subsequent price drop, any buyer of securities to whom the statement refers may recover the price difference only by proving that the statements were false or that there was a misleading omission contained within it.

\section{SA Section 12}

Section 12(a) of the Securities Act of 1933 provides grounds for recovery in two different situations. The first is for any offering or selling of securities that is made without a registered statement ${ }^{315}$ while the second is for the offering or selling of securities, by means of prospectus or oral communications, that contains an untrue statement of material fact or are otherwise misleading. ${ }^{316}$

In respect of the identification of the defendants that the plaintiff can bring to court, the language in Section 12(a) of the Securities Act of 1933 is more restrictive than Section 11: the opening of these two subsections state 'offers or sells' and further down also make clear that the defendant 'shall be liable [...] to the person purchasing such security from him'. 317 The language of the statute defines 'sale' or 'sell' to include 'every contract of sale or disposition of a security or interest in a security, for value' and 'offer' as 'every attempt or offer to dispose of, or solicitation of an offer to buy'. ${ }^{318}$ A strict reading of the statute would lead to the conclusion that only direct sellers would be liable for a violation of $\S 12$, but the Supreme Court has already decided that those who engage in solicitation may also

\footnotetext{
314 Securities Act of 1933, s 11(e).

315 Securities Act of 1933, s 12(a)(1).

316 Securities Act of 1933, s 12(a)(2).

317 Securities Act of 1933, s 12(a). See also Pinter v. Dahl 486 U.S. 622, 641-647 (1988).

318 Securities Act of 1933, s 2(a)(3).
} 
be sued under this section, as long as a sale has taken place. ${ }^{319}$ For Section 12(a)(2), the SEC has enacted a rule providing that only issuers can be deemed to be sellers. ${ }^{320}$

Some of the defenses are also similar. Knowledge by the plaintiff of the untrue statement or omission or the existence of a reasonable belief that the information was true and not misleading, if proved by the defendants, will exempt them from liability. ${ }^{321}$

The remedy in this section is either rescission of the transaction in case the plaintiff still has the securities, with payment of interest minus any dividends received, or, in case the securities have been sold, damages. ${ }^{322}$ Similarly as per $\S 11$, in respect of the cause of action regarding untrue and misleading statements, if the defendant proves that the losses were not due to the statements, damages are not recoverable. ${ }^{323}$

\section{b. Claims under the Securities and Exchange act of 1934}

The backbone of securities fraud liability in the United States is Rule 10b-5, promulgated under Section 10 of the Securities and Exchange Act of 1934. Section 10(b) of the Securities and Exchange Act of 1934 provides that

It shall be unlawful for any person, directly or indirectly, by the use of any means or instrumentality of interstate commerce or of the mails, or of any facility of any national securities exchange... to use or employ, in connection with the purchase or sale of any security registered on a national securities exchange or any security not so registered, or any securities based swap agreement, any manipulative or deceptive device or contrivance in contravention of such rules and regulations as the Commission may prescribe.... ${ }^{324}$

\footnotetext{
319 Pinter v. Dahl, (n 317) 643 ('the inclusion of the phrase "solicitation of an offer to buy" within the definition of "offer" brings an individual who engages in solicitation, an activity not inherently confined to the actual owner, within the scope of $\$ 12$ '); ibid 644 ('The purchase requirement clearly confines $\S 12$ liability to those situations in which a sale has taken place... The requirement, however, does not exclude solicitation from the category of activities that may render a person liable').

320 See 17 C.F.R. § 230.159A (2013).

${ }^{321}$ Securities Act of 1933, s 12(a)(2).

322 Securities Act of 1933, s 12(a)(2).

323 Securities Act of 1933, s 12(b).

324 Securities Exchange Act of 1934, s 10. See also Blue Chip Stamps v. Manor Drug Stores, 421 U.S. 723 (1975) and Birnbaum v. Newport Steel Corp., 193 F.2d 461 (2 ${ }^{\text {nd }}$ Cir. 1952).
} 
Under this Section, the SEC prescribed Rule 10b-5, which establishes the prerequisites of forbidden behavior regarding securities transactions subject to U.S. law. The Rule prohibits the employment of devices, schemes or artifices to defraud, the making of untrue statements or omissions of material facts that are misleading and the engagement in business that would operate as fraud, if such conduct is made in connection with the purchase or sale of securities. Even though the rule is also known as the securities fraud rule, it covers both fraudulent and non-fraudulent behavior. 325

The framework of Rule $10 \mathrm{~b}-5$ for private actions is based not only on statutory grounds. Most of its contours were judicially established, as expressed by Chief Justice Rehnquist's famous statement that Rule $10 \mathrm{~b}-5$ is 'a judicial oak which has grown from little more than a legislative acorn'.326 The private right of action itself is nowhere to be found in the legislative text, there being an 'implied' right that emerged from judicial decisions. ${ }^{327}$

The recognition of the rights under Rule 10b-5 and its scope has gone through an initial growth followed by a subsequent narrowing both through the development of jurisprudence ${ }^{328}$ and the requirements of the Private Securities Litigation Reform Act. ${ }^{329}$

The Private Securities Litigation Reform Act was enacted in the end of 1995 due to concerns about meritless and abusive suits. ${ }^{330}$ It was a statute intended to lower capital costs without destroying the incentives for meritorious lawsuits. ${ }^{331}$ The relevant changes

${ }^{325}$ Fraud is 'a knowing misrepresentation of the truth or concealment of a material fact to induce another to act to his or her detriment'. Fraud definition in Bryan A. Garner, Black's Law Dictionary (West Publishing Co. 2009). For an overview of the concept of fraud in securities regulation, see Samuel Buell, 'What is Securities Fraud?' (2011) 61 Duke Law Journal 511.

326 Blue Chip Stamps v. Manor Drug Stores (n 324) 737.

327 The first court to recognize this right of action was the United States District Court for the Eastern District of Pennsylvania in 1946, see Kardon v. National Gypsum Co., 69 F. Supp. 512 (D.C. Pa. 1946). The US Supreme Court only dealt with the issue in 1971, in Superintendent of Insurance of State of New York v. Bankers Life and Casualty Co, 404 U.S. 6 (1971).

${ }^{328}$ As an example, see Central Bank of Denver, N.A. v. First Interstate Bank of Denver, N.A. 511 U.S. 164 (1994) (finding that there are no private right of action against aiders and abettors of violators of Rule $10 \mathrm{~b}$ 5).

329 Private Securities Litigation Reform Act of 1995 (PSLRA), Pub. L. 104-67, 109 Stat. 737 (1995).

${ }^{330}$ H.R. Rep. No. 104-369, at 31 (1995) (Conf. Rep.).

331 See S. Rep. No. 104-98, at 4 (1995). 
for the purposes of this chapter were the safe-harbor for forward-looking statements, the heightened pleading standards and the change from joint and several to proportionate liability for some actors.

The forward-looking statement's safe-harbor diminished the range of application of Rule 10b-5. Its objective was to 'encourage issuers to disseminate relevant information to the market without fear of open-ended liability'. ${ }^{332}$ The safe-harbor is applicable to issuers, their representatives and underwriters ${ }^{333}$ regarding forward-looking statements that are identified as such or are immaterial. ${ }^{334}$ Even if the forward-looking statement is not identified as such and is material, the plaintiff still has to prove actual knowledge if a natural person made the statement, and if it was made by a business entity, that the statement was approved by an executive officer that had actual knowledge of the misleading or false information. ${ }^{335}$ Before, forward-looking statements would fall within the same category of other general statements, and the Private Securities Litigation Reform Act made it harder for a plaintiff to prevail on a suit based on misleading forwardlooking statements. ${ }^{336}$

Regarding the heightened pleading standard, the Private Securities Litigation Reform Act instituted a change, imposing a requirement that, in actions made under the Securities and Exchange Act of 1934 alleging an untrue statement of material fact or the omission of information that would make a statement misleading, the plaintiff must specify each alleged statement and the reason why they are deemed to be misleading. ${ }^{337}$ In respect of each of these statements or omissions attributed to the defendant, the plaintiff must also state 'with particularity facts giving rise to a strong inference ${ }^{338}$ that

332 H.R. Rep. No. 104-369, at 32 (1995) (Conf. Rep.).

333 Securities Act of 1933 s 27A(a) and Securities Exchange Act of 1934 s 21E(a).

334 Securities Act of 1933 s 27A(c) and Securities Exchange Act of 1934 s 21E(c).

335 Ibid.

${ }^{336}$ For an analysis of problems that may arise when forward-looking statements are mixed with general statements about the business, see Wendy Gerwick Couture, 'Mixed Statements: the Safe Harbor's Rocky Shore' (2011) 39 Securities Regulation Law Journal 257.

337 Securities Exchange Act of 1934 s 21D(b)(1).

338 The strong inference requirement was addressed by the U.S. Supreme Court in Tellabs Inc. v. Makor Issues \& Rights Ltd., 551 U.S. 308, 324 (2007) ('a complaint will survive, we hold, only if a reasonable person would deem the inference of scienter cogent and at least as compelling as any opposing inference one could draw from the facts alleged'). 
the defendant acted with the required state of mind', what is known as the scienter standard. ${ }^{339}$ It is also necessary to establish proof of loss causation. ${ }^{340}$

Therefore, to prevail on a $10 \mathrm{~b}-5$ lawsuit, it is necessary for plaintiff to prove '(1) a material misrepresentation or omission by the defendant; (2) scienter; (3) a connection between the misrepresentation or omission and the purchase or sale of a security; (4) reliance; (5) economic loss and (6) loss causation.'341 If these elements are not present, the defendant prevails on a motion to dismiss. ${ }^{342}$

Finally, the last modification by the PSLRA was the change from joint and several liability to proportionate liability. ${ }^{343}$ Joint and several liability is only available to the extent that the defendants knowingly committed the securities violation. ${ }^{344}$

There were many empirical studies after the PSLRA was enacted testing its consequences in the securities class action environment. The statute had the effect of reducing both nuisance and non-nuisance litigation. ${ }^{345}$ The PSLRA had two important strands of impact related to litigation: firstly, smaller companies or those with a lower market turnover became less likely to be defendants in respect of a securities class action; secondly, companies engaging in fraud where there was no hard evidence before the suit also became less likely to be sued. The greatest impact was on suits between $\$ 2$ million

339 Securities Exchange Act of 1934 s 21D(b)(2)(A). For Credit Rating Agencies or controlling persons the required state of mind is a different one, Securities Exchange Act of 1934 s 21D (b)(2)(B).

340 Securities Exchange Act of 1934 s 21D(b)(4).

${ }^{341}$ See Dura Pharmaceuticals, Inc. v. Broudo, 544 U.S. 336, 341-342 (2005).

${ }^{342}$ Securities Exchange Act of 1934 s 21D(b)(3)(A). These are requirements for pleading, and not for the plaintiff to obtain final judgment. If the plaintiff prevails on a motion to dismiss, it is still necessary to go to the end of the trial. Most lawsuits settle after this point.

${ }^{343}$ Securities Exchange Act of 1934 s 21D(f)(2)(B).

${ }^{344}$ Securities Exchange Act of 1934 s 21D(f)(2)(A).

345 Nuisance litigation is the type of lawsuit that the plaintiffs sue, even without a proper case, to try to reach a settlement due to the costs of the lawsuit to defendants. 
and $\$ 4$ million dollars. ${ }^{346}$ Even though there was a reduction in nuisance suits, Professor Choi is skeptical that this reform was beneficial to the general welfare of investors. ${ }^{347}$

Another important aspect in the liability design under Rule $10 \mathrm{~b}-5$ is the question of who can be a defendant in the lawsuit. The starting point is that the illegal conduct must be made in connection with the sale or purchase of securities. ${ }^{348}$ Buyers, sellers, brokers and the issuer may be defendants, but only those responsible for the statement may be put in this position. Aiders and abettors contributing to a statement, but who do not 'make' it, cannot be sued for a violation of Rule $10 \mathrm{~b}-5.349$

On the question of damages, they are generally limited to the difference between the transaction price of the security and its mean trading price during the 90 -day period starting on the day that the correct information was disseminated to the market. 350

In order to complete the overview of the liability system in securities litigation in the U.S., one more topic must be addressed: the fraud-on-market doctrine.

\section{The problem of reliance and the fraud on the market doctrine}

An important aspect of the liability regime in the United States for $10 \mathrm{~b}-5$ violations is procedural. Since the class action mechanism is constantly used in securities litigation, the class certification and pleading requirements play a major role in the development of the litigation. Most of the lawsuits settle after the motion to dismiss stage, and the ones that reach a verdict are minimal. ${ }^{351}$

346 Stephen J. Choi, 'Do the Merits Matter Less After the Private Securities Litigation Reform Act?' (2006) 23 The Journal of Law, Economics, \& Organization 598, 623.

347 Through a quick mathematical exercise, Professor Choi estimates that the benefit from eliminating nuisance suits during the period of the study would be around $\$ 16.2$ million, while the lost deterrence arising out of the legislative reform was $\$ 93.9$ million. Ibid .

34817 C.F.R. 240.10b-5.

349 See Central Bank of Denver, N.A. v. First Interstate Bank of Denver, N.A. (n 328).

350 Securities Exchange Act of 1934, s 21D(e)(1).

${ }^{351}$ In the dataset of the Cornerstone Research for the period of 1996 to 2011, only $8 \%$ of the securities class actions reached a ruling on summary judgment, while the rest was either dismissed or reached a settlement before. Cornerstone Research, Cornerstone Research, Securities Class Action Filings - 2011 in Review (2011) 18. 
The Basic v Levinson ${ }^{352}$ decision brought a major change in the traditional reliance requirements for securities litigation in the United States. ${ }^{353}$ Classically, to succeed in a claim of securities fraud, the plaintiff had to prove not only that had he known the truth, he would have acted differently, but also that the untruthful statement had a direct or proximate relation to the loss. ${ }^{354}$ These are the transactional causation, a 'but for' argument that absent the untruthfulness plaintiff would have acted in another way, and the loss causation, a connection between the statement and the loss caused. ${ }^{355}$

The fraud on the market theory ${ }^{356}$ was developed to deal with the plaintiff's reliance requirement in class actions. Requiring that every single member of a class prove that they relied on the allegedly false misstatement to certify the class would curb the possibility of the procedure since individual questions would overwhelm the common ones. $^{357}$

The presumption adopted was that shares traded on well-developed markets incorporate all available information into their securities prices, including any misrepresentations. ${ }^{358}$ Therefore, by engaging in securities transactions in the marketplace, there is a presumption that the buyer (or seller) has relied on the integrity of the price to do so, and to this extent also on any material misrepresentations made since they are incorporated into that market price. ${ }^{359}$

By transforming the question of reliance into a common problem, the fraud-onthe-market theory allows for the use of the class mechanism for securities litigation. Under the theory, there is no requirement that the purchaser had actually relied, or even

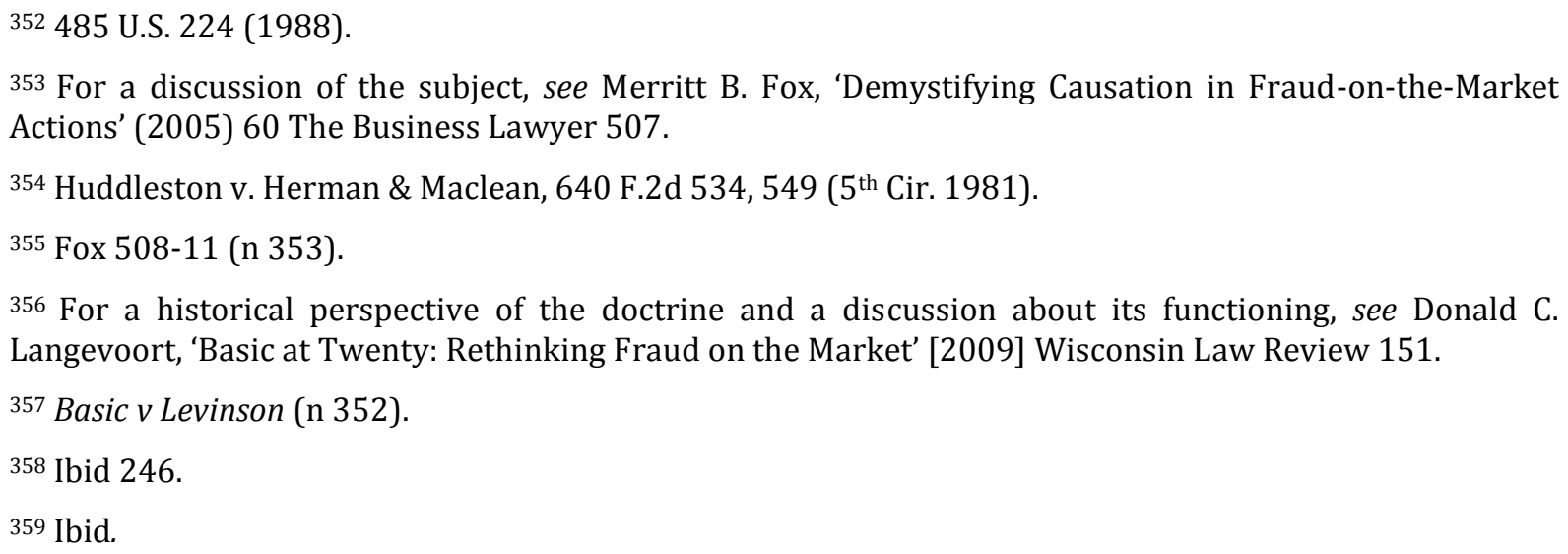


read, the misstatement under scrutiny. The important aspect is the presumption of reliance on market prices and the transfer of the misleading information to them.

Since 'fraud-on-the-market' theory consists of a presumption, defendants do have the possibility to rebut it. As long as it is demonstrated that the misstatement did not travel through the mechanisms of price incorporation, liability can be avoided. ${ }^{360}$

The doctrine has been the object of much criticism. Commentators have pointed that it may cause overcompensation, and to the extent that it is usually the issuer that pays for the outcome of these suits, it may even reduce the general welfare of investors, increasing social costs. ${ }^{361}$ Despite the criticisms, the doctrine is still in use and has recently been confirmed by the U.S. Supreme Court. 362

\section{B. European Union}

The liability regime in securities regulation in the European context has a twotiered framework: the first are the legal instruments of the European Union, the Treaties, directives and regulations, while the second is the internal legislation of the country. The securities markets are heavily regulated by European directives, which oblige Member States to implement legislation in compliance therewith, even though the liability provisions are left for national legislation.

\section{a. The European Perspective}

Disclosure in capital markets is regulated at the European level mainly through three different directives and their amending and implementing legislative provisions: ${ }^{363}$

360 'Any showing that severs the link between the alleged misrepresentation and either the price received (or paid) by the plaintiff, or his decision to trade at a fair market price, will be sufficient to rebut the presumption of reliance.; ) Ibid 248.

361 Paul G. Mahoney, 'Precaution Costs and the Law of Fraud in Impersonal Markets' (1992) 78 Virginia Law Review 623.

362 See Halliburton v. Erica P. John Fund, 573 U.S. _ (2014).

363 Directives are binding legislative instruments that the European Union member states are obliged to comply with by creating internal mechanisms that reflect the provisions of the Directives. 
the prospectus directive, 364 the transparency directive 365 and the market abuse directive. ${ }^{366}$ The European framework for securities regulation is structured around two main axes, market efficiency and the creation of a pan-European market for securities. ${ }^{367}$ Therefore, the set of problems arising at the European level that are addressed through regulation go beyond those discussed above, arising within the national spheres.

As is the case with the two other systems for civil liability discussed above, the provisions of these directives are designed to impose extensive disclosure duties on issuers, underwriters and other participants of capital markets. As a matter of EU Law, these directives do not have horizontal direct effect ${ }^{368}$ since they constitute obligations imposed on the Members States to implement measures internally. ${ }^{369}$ The details of the civil liability for disclosure are thus left to the Member States. ${ }^{370}$ The Prospectus Directive, for example, only provides that responsibility for the information should attach at least to the issuer (or its administrative, management or supervisory bodies), the offeror, the person asking for the admission to trading in a regulated market or the guarantor, as the case may be. ${ }^{371}$ The way in which liability should be deemed to arise and the relevant

364 Directive 2003/71/EC (Prospectus Directive). See also Commission Regulation (EC) 809/2004, Commission Regulation (EC) 211/2007, Commission Regulation (EC) 1569/2007, Directive 2010/73/EU, Commission Delegated Regulation (EU) 486/2012, Commission Delegated Regulation (EU) 862/2012, Commission Delegate Regulation (EU) 759/2013, Delegated Regulation (EU) 382/2014.

365 Directive 2004/109/EC (Transparency Directive), Commission Directive 2007/14/EC, Commission Regulation (EC) 1569/2007, Commission Decision 2008/961/EC, Directive 2013/50/EU.

366 Directive 2003/6/EC (Market Abuse Directive), Commission Regulation (EC) 2273/2003, Commission Directive 2003/124/EC, Commission Directive 2003/125/EC, Commission Directive 2004/72/EC.

367 See also Directive 2009/65/EC (UCITS Directive), the European legislative instrument on the coordination of laws, regulations and administrative provisions relating to undertakings for collective investment in transferable securities.

${ }^{368}$ They have vertical direct effect if the Member State does not implement the directives in the allotted time. See Case C-41/74 Van Duyn v Home Office [1975] Ch. 358 and Case C- 148/78 Pubblico Ministerio v Ratti [1979] ECR 1629.

${ }^{369}$ See Damian Chalmers, Gareth Davies and Giorgio Monti, European Union Law (2nd edn, Cambridge University Press 2010) 286-93. The exception to this rule is that directives may be directly effective against the Member States if the Member State has not transposed a given directive into internal legislation by the end of the transposition period. See also Minister of the Interior v. Cohn-Bendit [1980] 1 CMLR 543.

370 Moloney, EC Securities Regulation 164-65 (n 227).; Iris H. Y. Chiu, Regulatory convergence in EU securities regulation (Kluwer Law International 2008) 160-62 See also Case C-174/12 Hirmann v Immofinanz AG (ECJ $2^{\text {nd }}$ Chamber, 19 December 2013).

371 Prospectus Directive, art 6. 
remedies are not provided for. Yet Member States have to adapt their systems so they are in compliance with the general framework of the directives. ${ }^{372}$

\section{b. Implementation in Domestic Systems: the Case of Spain}

The law setting up the regulatory regime for securities in Spain is Law 24/1988. This law was created in 1988 to give coherence to the reforms that had been made in the Spanish securities market regulations in the years before, and in light of the possibility of a European capital market being established by 1992; the idea was thus to modernize and prepare the Spanish markets in case this came to happen. 373 The law created the Comisión Nacional del Mercado de Valores [hereinafter CNMV], ${ }^{374}$ the agency responsible for regulating and supervising financial markets in Spain, ${ }^{375}$ and set out the framework for the duties of market participants at many different levels.

A prospectus is required for securities that are to be admitted to trading in a secondary official market ${ }^{376}$ or for an initial public offering. ${ }^{377}$ The obligation of preparing a prospectus brings also disclosure requirements. Under Spanish law, a prospectus has to provide sufficient information for investors to evaluate the financial situation of the issuer and their future possibilities; it must be drafted in an easily readable and comprehensible manner. ${ }^{378}$ The responsibility for the prospectus' information lies with the issuer, the offeror, the entity asking for the admission to trade in a regulated market and all of their managers. ${ }^{379}$

\footnotetext{
372 See Niamh Moloney, How to protect investors: lessons from the EC and the UK (Cambridge University Press 2010) 444-47.

${ }^{373}$ See Law 24/1988, Introduction.

${ }^{374}$ Law 24/1988, art 13.

375 The CNMV can impose normative instruments that are known as 'Circulares', as long as there is previous authorization either by a 'Real Decreto' or an 'Orden del Ministerio de Economía y Hacienda'. Law 24/1988, art 15.

${ }^{376}$ Law 24/1988, art 26.

377 Law 24/1988, art 30 bis.2.

${ }^{378}$ Law 24/1988, art 27.1.

${ }^{379}$ Law 24/1988, art 28.1.
} 
After the securities are issued and are trading in a regulated market, issuers have a duty to disclose their annual financial statements, ${ }^{380}$ which have to be audited. ${ }^{381}$ Every three months, issuers must also make a statement which includes information about significant operations in the time period and their impact on the financial situation of the company. ${ }^{382}$ The responsibility for the annual financial statements falls to at least the issuer and its officers, under the conditions that the CNMV may establish. ${ }^{383}$

This responsibility encompasses all the damages that the owners of such securities may have, if the information provided does not faithfully reflect the situation of the issuer. ${ }^{384}$

A similar duty of information is also imposed on financial intermediaries. They are obliged to give clear and non-misleading information to their clients, with extra obligations when these institutions provide advisory services for their clients. ${ }^{385}$

Like the U.S. and the Brazilian system, the Spanish system also has requirements of disclosure for relevant information ${ }^{386}$ and explicitly puts forward a 'disclose or abstain' policy for privileged information. ${ }^{387}$ Relevant information is deemed to be any information that may affect a reasonable investor in transacting with securities, influencing its price in the secondary market. ${ }^{388}$ Issuers have to make this kind of information public, ${ }^{389}$ unless, under their own responsibility, they believe it may prejudice their legitimate interests. ${ }^{390}$

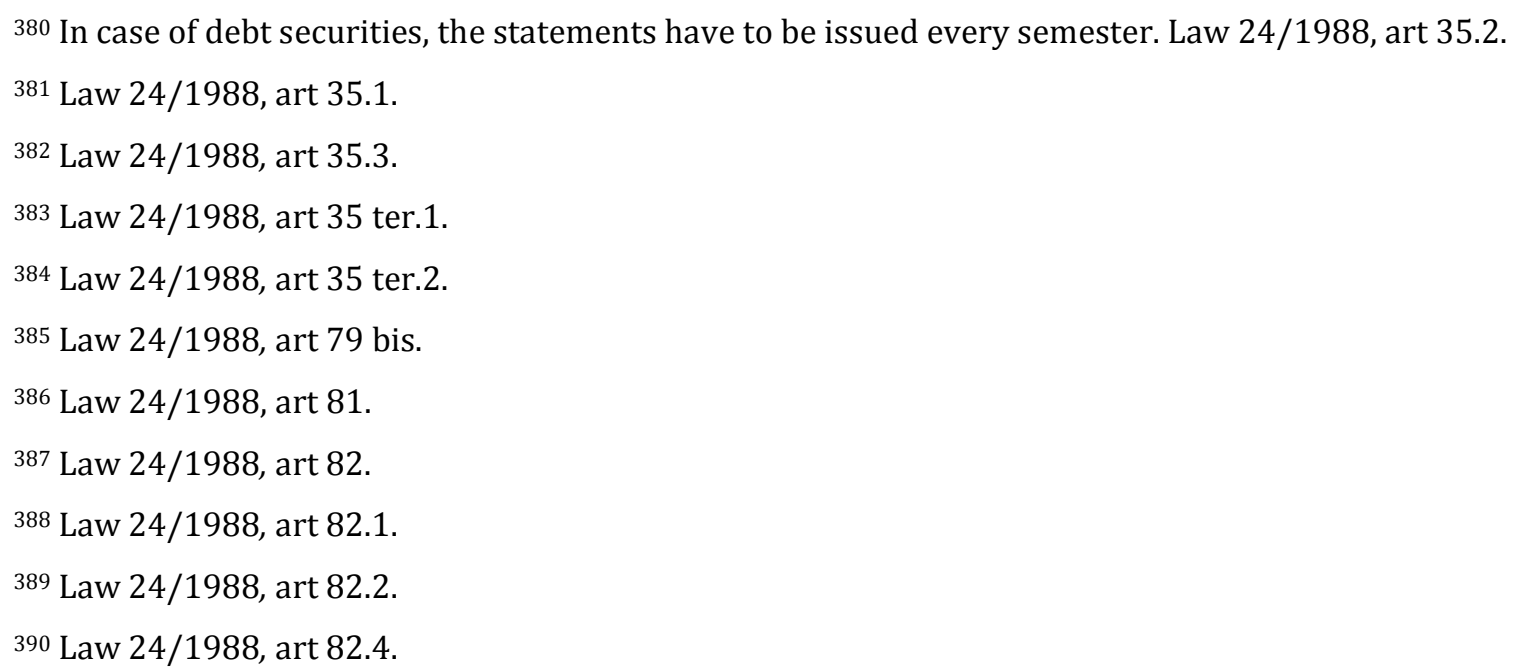


Even though there is a clear liability system against issuers, there is very little litigation on the subject. Most of the litigation regarding financial markets is of the financial intermediary-investor type.

\section{c. Implementation in Domestic Systems: Other Jurisdictions}

Liability systems for issuers in other EU Member States vary to the extent that there are different legal regimes. They can be based on the country's tort liability, on its contractual liability, or specifically on the liability arising out of the relevant prospectus and transparency regulations available. Three examples, regarding prospectus liability, are sufficient to illustrate the difference: namely, France, Germany and the UK.

In France, liability is based either on the general tort regime or on the contractual liability regime. ${ }^{391}$ In any event, for liability to attach it must be proven that there exists loss or damage, fault on the part of the persons who signed the prospectus and that there exists a causal link with the harm suffered. ${ }^{392}$

In Germany, the liability regime is a specific one, implemented in the German Securities Prospectus Act, but complemented by the application of German tort law. ${ }^{393}$ The purchaser has to prove that the prospectus is incorrect or incomplete, that the securities were purchased after the prospectus was published, and that the purchase was made within six months after the first trading of the securities or the public offering. ${ }^{394}$ Pre-contractual liability only arises in case the transaction is a direct one between the purchaser and the issuer. 395

Finally, in the UK, prospectus liability can be based on section 90 of the Financial Services and Markets Act 2000, common law negligence or common law deceit. ${ }^{396}$ Under

391 ESMA, Report: Comparison of Liability Regimes in Member States in Relation to the Prospectus Directive (2013) Annex III 77.

392 Ibid Annex III 79.

393 Ibid Annex III 87.

394 Ibid Annex III 89.

395 Ibid Annex III 88.

396 Ibid Annex III 313. 
section 90, untrue or misleading statements, or omissions that were required, constitute sufficient grounds for liability, with the available defense being reasonable belief or reliance on an expert. 397

The standards for liability of these countries, and overall in Europe, are similar, 398 but notwithstanding this similarity the actual operation of liability may differ, sometimes because there are additional aspects that must be proved ${ }^{399}$ or because the standard of proof is diverse. ${ }^{400}$ The recoverable damages can also be different. ${ }^{401}$ Therefore, the liability regime will depend on the applicable legal regime, which can differ substantially notwithstanding EU harmonization efforts, having the potential to create legal uncertainty for issuers and consequently to undermine the free movement of capital principle. The positive aspect of the EU framework is that despite these differences in liability regimes, the operation of the directives and regulations function as a convergence tool, continuously approximating these different legal regimes.

\section{Brazil}

Securities regulation in Brazil is also extensive. Similarly to the U.S., Brazil has an agency in charge of regulating the securities market. The agency is known as Comissão de Valores Mobiliários [hereinafter CVM], created by Law 6.385/76. The CVM has the power to define what can be considered fraudulent and non-equitable practices in the initial offering or intermediation of securities. ${ }^{402}$

Through different legal instruments, the CVM has imposed many duties to issuers and market participants both in the initial offering of securities as well as duties regarding the trading of securities in the secondary market. As the SEC, the CVM not only sets the

\footnotetext{
397 Ibid Annex III 313-315.

398 Ibid para 41.

399 Ibid para 44.

400 Ibid para 42.

401 Ibid paras 48-50.

402 Law 6.385/76, art 18, II, b).
} 
rules of the game, but it also has a strong enforcement presence in securities regulation, having the power to bring administrative proceedings against irregularities.

In a way that differs from the U.S. though, the regime for securities liability in private litigation is not based predominantly on particular provisions of securities law, but relies heavily on the general provisions of civil liability of the Brazilian Civil Code. ${ }^{403}$ It is interesting to mention that the litigation of these cases in Brazil is well below the U.S level. To facilitate the analysis, this section is divided into the duties of market participants and the general liability framework under the Brazilian Civil Code.

\section{a. Disclosure Duties}

With its authority derived from Brazilian legislation, the CVM has issued many different legal rules organizing the securities market in Brazil. Within these rules, there are many duties imposed to market participants on their proper behavior in the market. Disclosure obligations are widespread, and specific obligations are dependent on what transactions are being made and the identification of the person committing the act.

Different regulations are applicable, imposing different disclosure duties, depending on whether what is relevant is an issuance of securities or secondary market trading. There are basically two different Instructions ${ }^{404}$ that impose disclosure duties to market players. 405 They are the Instruction CVM 400, regulating the issuance of securities to the public and Instruction CVM 358, regulating the disclosure of material information and insider trading.

The first duty is the preparation of the prospectus for the issuance of securities, the responsibility for which falls to both the offeror ${ }^{406}$ and the lead underwriter. ${ }^{407}$ The

403 Law 10.406/2002.

${ }^{404}$ An Instruction is one of the legal mechanisms through which the CVM regulates the market.

405 There are also other Instructions with more specific disclosure duties, but their analysis is beyond the scope of this chapter.

406 Brazilian securities law makes a distinction between offeror and issuer, but usually these two legal categories are vested in the issuer.

407 Instruction CVM 400, art 38. 
information in the prospectus should neither omit relevant facts nor have information that may mislead investors. ${ }^{408}$

While responsibility for the prospectus falls to both the offeror and the lead underwriter, the duty of care is distinct: the offeror is responsible for the 'truthfulness, consistency, quality and sufficiency of the information', ${ }^{409}$ while the lead underwriter is under a duty to exercise due care to guarantee the accuracy of the information. ${ }^{410}$

The second duty is one of disclosure of material facts. The list of facts considered to be material is extensive and comprises occurrences that are likely to influence securities prices, the investor's decision to buy or sell them or the investor's decision to exercise any rights arising out of the above-mentioned security. 411

Within the corporate structure, the person responsible for disclosing material facts is the Director of Investor Relationship, but in case disclosure is not made, if other actors (such as controlling shareholders, directors, Management Counsel ${ }^{412}$ members, Fiscal Counsel or any other technical or consulting body within the corporation that is created by the corporate charter) have any knowledge about it, they also become responsible if they do not communicate the material fact promptly to the CVM. ${ }^{413}$ The disclosure may be exempted after a request to the CVM if there is a belief that it may harm a legitimate interest of the company. ${ }^{414}$ Even though the legislation is not explicit about the liability of the issuer, it can be implied from the goals of the legal framework; such liability has already been affirmed by the Tribunal de Justiça de São Paulo. ${ }^{415}$

Compared to the United States system, the standards of conduct under the Brazilian system are similar: the issuer and underwriter have a duty to disclose

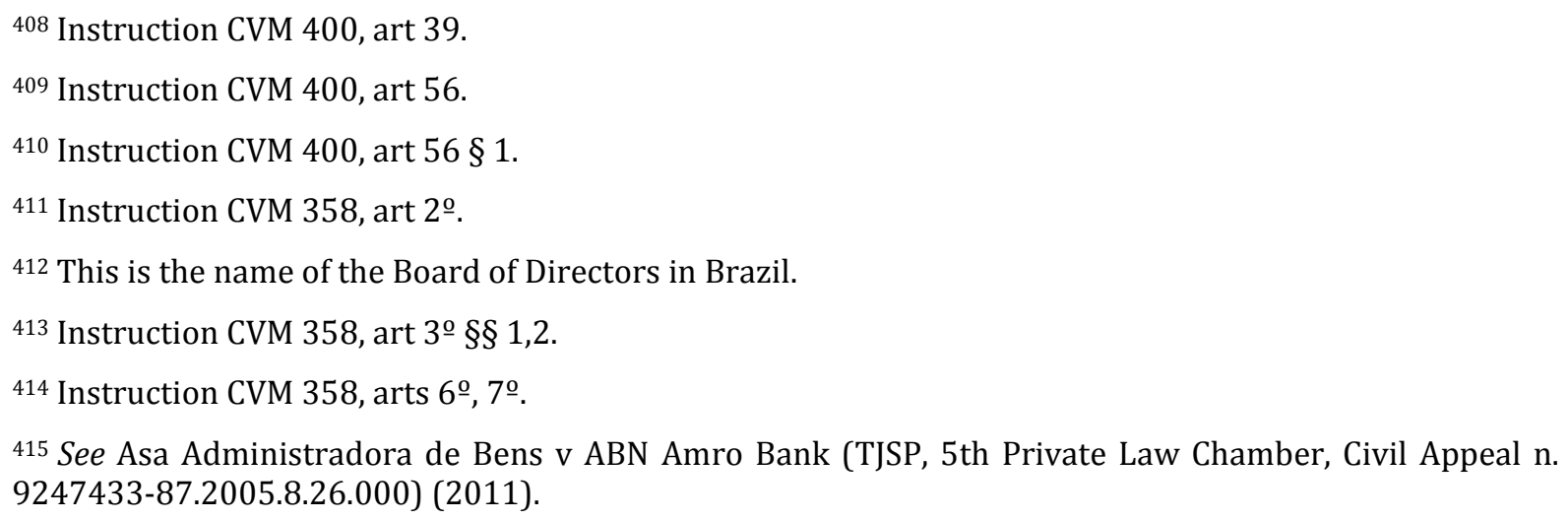


information in an initial offering while the issuer and its officers have an ongoing duty to disclose relevant facts to the market.

\section{b. The Liability Regime}

The liability regime in securities fraud and misrepresentation in Brazil arises out of the operation of the provisions of the Brazilian Civil Code. For liability to arise, it is firstly necessary to assess the existence of a legal duty that can be breached. The legal duties in securities matters were analyzed in the last section.

Legal duties are always primary juridical obligations. Their breach, when generating harm, gives rise to liability, a secondary obligation that arises out of the violation of the duty. ${ }^{416}$ The relevant provision of the Brazilian Civil Code provides the following: 'anyone that, by an illicit act [...], causes harm to another, is obliged to repair the harm.' ${ }^{417}$ Illicit acts are those that violate rights and cause harm to others, whenever they are made by a voluntary action or omission, negligence or imprudence. ${ }^{418}$

Therefore, from the language of the statute, not only the duty and its breach are necessary for liability to arise, but harm must also be suffered. A logical consequence of this necessity is the causality relationship between the action or the omission that violates a right and the harm arising out of it. Without a causal relationship, the secondary obligation to repair liability does not arise.

The harm caused will constitute the measure of damages to be paid in this kind of lawsuit, but the problem is that the jurisprudence has not yet developed a method on how to measure harm arising from securities litigation. After a survey of the São Paulo and Rio de Janeiro Tribunals' jurisprudence repositories, the only reference regarding damages in this type of case was found in Asa Adminstradora de Bens v. ABN Amro Bank S.A. ${ }^{419}$ The case was about the non-disclosure of a contract where ABN Amro S.A. would buy shares

416 Carlos Roberto Gonçalves, Direito Civil Brasileiro, Volume IV: Responsabilidade Civil (Editora Saraiva 2009).

417 Brazilian Civil Code, art 927.

418 Brazilian Civil Code, art 186. The specific language is: 'anyone that, by voluntary action or omission, negligence or imprudence, violates a right and causes harm to other, even if exclusively moral, commits and illicit act'.

419 (n 415). 
of Banco Real S.A. and assume its control. After the contract was signed, but before the shares were effectively traded and the control of Banco Real S.A. had changed, ABN Amro made tender offers and bought shares of these companies in the market. The court determined that the defendant should 'indemnify the harm suffered by plaintiffs arising out of the sale of these shares, harm which corresponds to the difference between the value effectively owed and the one paid...' ${ }^{420}$ Then the court enrolled a specialist to calculate the amount of harm done. ${ }^{421}$

In this particular case, not only was the harm not proven, but moreover there were no reasonable grounds to believe that the plaintiffs were harmed. It is dangerous to imply harm from the mere lack of information disclosure, since it is not always clear, depending on the information that was not disclosed, if the security price would go up or down in case the particular information had indeed been released to the public. ${ }^{422}$ Harm therefore should not be assumed abstractly, implied from the mere breach of duty to inform by the issuer, but must be proved, even if a more lax standard of proof is used.

This was the concern of James Siano, the dissenting Justice. ${ }^{423}$ In fact, after the announcement of the material fact underpinning this dispute, the share prices of the securities that were sold by plaintiffs actually fell, ${ }^{424}$ a situation that would leave the plaintiffs with fewer assets in the case that they had not sold their securities. This constitutes strong evidence that if there was a mispricing due to the non-disclosure of material information to the market, it was one that fell in favor of plaintiffs. This suggests the plaintiffs were not harmed and no liability should have arisen out of this breach of

${ }^{420}$ Asa Adminstradora de Bens v. ABN Amro Bank S.A. (n 415) 32.

421 Ibid.

422 Of course there are some cases where actual harm can be implied, for example when an oil company hides the fact that one of its main oil platforms has exploded.

423 See Dissenting Opinion in Asa Adminstradora de Bens v. ABN Amro Bank S.A. (n 415).

${ }^{424}$ According to the estimates of defendants, the share price fell from $30 \%$ to $35 \%$, but this assertion was not specifically contested by plaintiffs in the lawsuit. 
disclosure duties by Banco Real S.A., ${ }^{425}$ at least concerning the specific plaintiffs in this case. ${ }^{426}$

\section{Comparing Disclosure Liability Standards}

The private liability standards among the jurisdictions under study are fairly similar. Issuers of securities have to be truthful and disclose material information to their investors; many surrounding service providers are under a duty of due diligence to assert that the information provided is correct. The table below is a comparative table of the prohibited conducts, possible defendants, defenses and damages, as established in each legal system:

\begin{tabular}{|c|c|c|c|c|}
\hline $\begin{array}{l}\text { Liability } \\
\text { Standards }\end{array}$ & Defendants & Prohibited Conduct & Defenses & Damages \\
\hline \multicolumn{5}{|l|}{ Country } \\
\hline \multicolumn{5}{|l|}{ USA } \\
\hline $\begin{array}{ll}\text { SA } & \text { Section } \\
11 & \end{array}$ & $\begin{array}{l}\text { issuer; signers of } \\
\text { the registration } \\
\text { statement; } \\
\text { directors; } \\
\text { certifiers; } \\
\text { underwriters }\end{array}$ & $\begin{array}{l}\text { Untrue statement or } \\
\text { misleading omission }\end{array}$ & $\begin{array}{l}\text { Resignation; } \\
\text { Resignation and } \\
\text { notice; plaintiff's } \\
\text { knowledge of } \\
\text { statement; } \\
\text { reasonable belief } \\
\text { in truth }\end{array}$ & $\begin{array}{l}\text { Price paid } \\
\text { minus price } \\
\text { sold at the date } \\
\text { of suit (or } \\
\text { before) }\end{array}$ \\
\hline $\begin{array}{ll}\text { SA } & \text { Section } \\
12 & \end{array}$ & $\begin{array}{l}\text { Seller or } \\
\text { solicitor }\end{array}$ & $\begin{array}{l}\text { Sales in violation of Section } 5 \\
\text { or untrue and misleading } \\
\text { statements in connection } \\
\text { with a prospectus or oral } \\
\text { communication }\end{array}$ & $\begin{array}{l}\text { Reasonable care } \\
\text { (only for } 12(a)(2))\end{array}$ & $\begin{array}{l}\text { Rescission } \\
\text { (with interest } \\
\text { minus } \\
\text { dividends) or } \\
\text { damages }\end{array}$ \\
\hline
\end{tabular}

425 Banco Real S.A., and not ABN Amro S.A., was the party that had the duty to disclose relevant information to the market.

${ }^{426}$ If the plaintiffs were the ones who bought the shares, harm would be more evident. 


\begin{tabular}{|c|c|c|c|c|}
\hline Rule 10b-5 & $\begin{array}{l}\text { 'any person' } \\
\text { who makes a } \\
\text { material } \\
\text { misstatement }\end{array}$ & $\begin{array}{l}\text { In connection with the } \\
\text { purchase or sale of any } \\
\text { security: } 1 \text { ) employ device, } \\
\text { artifice or scheme to } \\
\text { defraud; } 2 \text { ) make an untrue } \\
\text { statement or omit a material } \\
\text { fact (misleading statement; } \\
\text { 3) engage in acts or practices } \\
\text { that would operate as fraud } \\
\text { or deceit. }\end{array}$ & General defenses & $\begin{array}{l}\text { Out-of-pocket } \\
\text { damages in } \\
\text { open market } \\
\text { transactions } \\
\text { and rescission } \\
\text { or restitution } \\
\text { in face-to-face } \\
\text { transactions }\end{array}$ \\
\hline \multicolumn{5}{|l|}{ Brazil } \\
\hline Prospectus & $\begin{array}{l}\text { Issuer; offeror; } \\
\text { underwriter; } \\
\text { officers of the } \\
\text { underwriter, the } \\
\text { offeror and the } \\
\text { issuer }\end{array}$ & $\begin{array}{l}\text { Hide material facts or induce } \\
\text { investors in error. }\end{array}$ & General defenses & $\begin{array}{l}\text { Compensatory } \\
\text { damages }\end{array}$ \\
\hline $\begin{array}{l}\text { Relevant } \\
\text { Information }\end{array}$ & $\begin{array}{l}\text { Issuer, } \\
\text { controlling } \\
\text { shareholders, } \\
\text { directors, } \\
\text { counsel } \\
\text { members }\end{array}$ & $\begin{array}{l}\text { Non-disclosure of relevant } \\
\text { facts }\end{array}$ & $\begin{array}{l}\text { Prompt } \\
\text { communication to } \\
\text { CVM (for personal } \\
\text { liability of other } \\
\text { persons when the } \\
\text { Investor Relations } \\
\text { Director omits } \\
\text { information); }\end{array}$ & $\begin{array}{l}\text { Compensatory } \\
\text { damages }\end{array}$ \\
\hline \multicolumn{5}{|l|}{ Spain } \\
\hline Prospectus & $\begin{array}{l}\text { Issuer, offeror, } \\
\text { person } \\
\text { requesting } \\
\text { admission to } \\
\text { trading; } \\
\text { managers and } \\
\text { underwriters }\end{array}$ & $\begin{array}{l}\text { False information in the } \\
\text { prospectus }\end{array}$ & General defenses & $\begin{array}{l}\text { Compensatory } \\
\text { damages }\end{array}$ \\
\hline
\end{tabular}




\begin{tabular}{|l|l|l|l|l|}
\hline & & & & \\
\hline $\begin{array}{l}\text { Relevant } \\
\text { Information }\end{array}$ & $\begin{array}{l}\text { Issuer and } \\
\text { managers }\end{array}$ & $\begin{array}{l}\text { Information that does not } \\
\text { provide a faithful } \\
\text { representation of the issuer }\end{array}$ & General defenses & $\begin{array}{l}\text { Compensatory } \\
\text { damages }\end{array}$ \\
\hline Information & $\begin{array}{l}\text { Financial } \\
\text { services } \\
\text { providers }\end{array}$ & $\begin{array}{l}\text { Provision of inadequate } \\
\text { information }\end{array}$ & General defenses & $\begin{array}{l}\text { Compensatory } \\
\text { damages }\end{array}$ \\
\hline
\end{tabular}

The standard of conduct is quite similar in every jurisdiction since the idea behind these regulatory regimes is to diminish informational asymmetry by promoting a market where there is disclosure of truthful information. Some differences can be identified in respect of the scope of liability, if joint and several or if proportional to the act; the calculation of damages, which may be done through different methods, depending on the standard that is breached (especially in the United States); and finally the available defenses, of which some jurisdictions can provide extras, in addition to those generally used in other liability cases.

Moreover, another important difference is the legal background structuring the private right of action in securities litigation: in the United States, this has been created and extracted from the legal statutes on securities regulation and by judicial decisions; in Spain, it is based on securities laws, ${ }^{427}$ while in Brazil it is a corollary of the general liability framework available within its legal system.

Finally, even though the standards of conduct may be generally similar, the operation of liability can vary substantially, even in places where the standard of conduct 
is harmonized, such as in the EU, ${ }^{428}$ creating the necessity of engaging efficient private international law rules so as to avoid legal uncertainty. ${ }^{429}$

\section{Legal Framework for Securities Liability - Financial Intermediaries}

Financial intermediaries are those that operate between markets and investors. They can trade on their own account, buying and selling securities for themselves, or they can act as pure intermediaries, executing trades for the investors. In any event, together with the execution of these transactions, they may also provide other types of financial services, such as advising their clients as to the kinds of investments in which they should invest or by managing their portfolio.

As a general matter, when financial intermediaries are transacting in securities, they are also subsumed to the disclosure regime, being prohibited to engage in these transactions through the use of false or misleading information; in addition to the securities regulation regime, they are also subject to specific regimes regulating their conduct in providing financial services.

In the United States, the securities regulation liability regime for financial intermediaries is also anchored in Rule 10b-5, having another layer of protection - either through the Investment Advisers Act of 1940 or the rules of FINRA, the Self-Regulatory Organization in charge of regulating the securities industry - 430 coupled with the common contractual liability regime.

The difference between the legal sources that are applicable to financial intermediaries depends on whether they are classified as broker-dealers or as investment advisers. In theory, while broker-dealers have to comply only with the suitability

428 See ESMA (n 391).

${ }^{429}$ See Chapter X.

430 The provisions regulating SROs in the United States are found in Section 19 of the Securities and Exchange Act of 1934. On the formation of Finra, see SEC Release No. 34-56145 (26 July 2007). 
standard in advising clients about products, ${ }^{431}$ investment advisers owe clients a complete fiduciary duty, including the duties of loyalty and care. ${ }^{432}$ In practice, this distinction may be blurred when brokers hold discretionary accounts of their clients 433 or act as their client's agent, in which case, fiduciary duties would also be owed, even though the extent of the duty or the determination of when it should be applied is not quite clear in the American legal system. ${ }^{434}$ The institutional background for dispute resolution is also distinct since broker-dealers are not only subject to the regulatory overview of FINRA, but disputes arising with investors are also solved through arbitration by a panel organized according to FINRA's arbitration system. ${ }^{435}$

In any event, the distinction between the fiduciary duty owed by investment advisers and the suitability standard with which broker-dealers must comply when selling securities to clients has to be made clear. The suitability standard requires that the broker-dealer or an associated person 'have a reasonable basis to believe that a recommended transaction or investment strategy involving a security or securities is suitable for the customer, based on the information obtained through the reasonable diligence [...] to ascertain the customer's investment profile', ${ }^{436}$ while the fiduciary duty imposes, in addition to the suitability requirement, that the adviser acts in the best interest of the client and prohibits, absent disclosure, conflicts of interest between the fiduciary and the principal or between principals of the same fiduciary. 437

The situation in the United States at the moment is complicated in respect of the standard of conduct applicable to financial intermediaries. Broker-dealers at times do provide investment advice while being held to a lower standard than investment advisers.

431 SEC Section 913 Study 59-66.

432 SEC Section 913 Study 21-22.

433 A discretionary account exists when a client opens an account with a broker or an investment advisor and they can trade on that account without the client's consent. See also SEC Section 913 Study 54-55.

${ }^{434}$ Arthur B. Laby, 'Selling Advice and Creating Expectations: Why Brokers Should be Fiduciaries' (2012) 87 Washington Law Review 707, 724-25.

435 On the institutional design of the FINRA arbitration system and its flaws, see chapter VII.

436 FINRA Rules, s 2111.

437 The fiduciary duty under the Investment Advisers Act of 1940 requires utmost good faith, full and fair disclosure of all material facts and reasonable care to avoid misleading clients. See SEC v. Capital Gains Research Bureau, Inc., 375 U.S. 180 (1963); See also Laby 725 (n 434). 
There have been some proposals for reform, ${ }^{438}$ especially after the enactment of the Dodd-Frank Act and the study by the SEC on the subject, but it still is not clear if this will continue to constitute the liability regime for financial intermediaries in securities transactions.

In a manner different from the United States, which defines the intermediary liability according to the intermediary classification within the regulatory system and the activity performed, 439 in the European Union, the standard of conduct is defined according to the category of the client with whom the financial intermediary is transacting and the type of service offered. ${ }^{440}$ There are three main categories of duties owed by financial intermediaries, which arise depending on whether the party with whom they are transacting is a retail investor, professional investor or eligible counterparty. ${ }^{441}$

Fundamentally, investment services intermediaries must 'act honestly, fairly and professionally in accordance with the best interests of its clients', ${ }^{442}$ while they are also obliged to execute orders on the terms most favorable to the client ${ }^{443}$ and to implement measures to 'provide for the prompt, fair and expeditious execution' of orders. ${ }^{444}$ Depending on whether the financial intermediary is providing investment advice, other types of investment services or execution-only services, a duty of suitability or appropriateness may also exist.

The suitability requirement is applicable when investment advice is provided, and necessitates that the investment firm obtains the 'necessary information regarding the client's or potential client's knowledge and experience in the investment field [...], his financial situation and his investment objectives' so that the firm can assess and

438 See ibid SEC Section 913 Study; Graham Ravdin, 'One Step Forward, Two Steps Back: Arguing for a Transatlantic Investor Protection Regime’ (2012) 50 Columbia Journal of Transnational Law 490.

${ }^{439} \mathrm{At}$ least theoretically, since broker-dealers are not supposed to give investment advice that is not 'solely incidental', but often, they end up doing so. See Investment Advisers Act of 1940, s 202 (a)(11)(C).

440 Moloney, EC Securities Regulation 396-97 (n 227). The regulatory framework is set by the Markets in Financial Instruments Directive and its implementing regulation: Directive 2004/39/EC (MIFID Directive), Commission Directive 2006/73/EC, Commission Regulation (EC) 1287/2006.

441 See Directive 2004/39/EC, arts 19(10) and 24(2).

442 Directive 2004/39/EC, art 19(1).

443 Directive 2004/39/EC, art 21(1).

${ }^{444}$ Directive 2004/39/EC, art 22(1). 
recommend financial instruments that are suitable to the client. 445 The appropriateness standard is applicable when investment services other than investment advice is provided, and requires that the investment firm ask the 'client to provide information regarding his knowledge and experience in the investment field relevant to the specific type of product offered or demanded', so the investment firm can assess whether the product is appropriate for the client. ${ }^{446}$ Not only is the scope of the appropriateness standard requirement lower, necessitating only the provision of information regarding the investor's knowledge about the product, but moreover, it is not determinant on the provision of services; if the intermediary finds that the product is not appropriate or if the client fails to inform the intermediary about his knowledge and experience, the intermediary may still proceed and provide the service as long as a warning is provided. ${ }^{447}$

Remaining within the 'type of service' categorization, the execution-only service does not impose any kind of duty on intermediaries; however, certain requirements must be fulfilled for this category to be applicable: 1) the instruments covered must be shares traded in a regulated market, money market instruments, bonds or other forms of securitized debt (excluding those embedding a derivative); 2) the service must be provided at the initiative of the client and 3) the client must be informed that the suitability requirement is not applicable. 448

Moving up the ladder of investor sophistication, the requirements when transacting with professional investors are different. The difference when dealing with a professional investor is that, in respect of the suitability and appropriateness requirements, the financial intermediary is entitled to assume that they have the necessary experience and knowledge in respect of the products for which they are classified as professional investors and that as such, the client is financially able to bear

\footnotetext{
445 Directive 2004/39/EC, art 19(2).

${ }^{446}$ Directive 2004/39/EC, art 19(5). If the financial intermediary fails to obtain the information about the client it may not recommend investment services or financial instruments to the client. Commission Directive 2006/73/EC, art 35(5).

${ }^{447}$ Ibid.

${ }^{448}$ Directive 2004/39/EC, art 19(6).
} 
the risks of such investment; ${ }^{449}$ this reduces considerably the duties of the financial intermediary.

Finally, the last category of clients is that of the eligible counterparty; this category imposes the least requirements on investment intermediaries. When dealing with this category of client, the duties of suitability, appropriateness, most favorable terms execution and measures for the prompt, fair and expeditious execution are not required. 450

\begin{tabular}{|c|c|c|c|}
\hline \multicolumn{4}{|c|}{ Standards of Conduct - EU } \\
\hline & Retail Investor & $\begin{array}{l}\text { Professional } \\
\text { Investor }\end{array}$ & $\begin{array}{l}\text { Eligible } \\
\text { Counterparty }\end{array}$ \\
\hline Investment Advice & $\begin{array}{l}\text { Suitability } \\
\text { requirement } \\
\text { (mandatory) / } \\
\text { Most favorable } \\
\text { execution / } \\
\text { Procedures for } \\
\text { prompt execution }\end{array}$ & $\begin{array}{l}\text { Client's knowledge } \\
\text { and financial } \\
\text { capacity are } \\
\text { presumed / Most } \\
\text { favorable } \\
\text { execution / } \\
\text { Procedures for } \\
\text { prompt execution }\end{array}$ & \multirow{2}{*}{$\begin{array}{l}\text { There are no } \\
\text { requirements of } \\
\text { suitability, } \\
\text { appropriateness, } \\
\text { most favorable } \\
\text { execution or } \\
\text { procedures for } \\
\text { prompt execution }\end{array}$} \\
\hline $\begin{array}{l}\text { Investment } \\
\text { Services }\end{array}$ & $\begin{array}{l}\text { Appropriateness } \\
\text { requirement } \\
\text { (waivable by } \\
\text { warning) / Most } \\
\text { favorable } \\
\text { execution }\end{array}$ & $\begin{array}{l}\text { Client's knowledge } \\
\text { is presumed / Most } \\
\text { favorable } \\
\text { execution }\end{array}$ & \\
\hline
\end{tabular}

${ }^{449}$ Commission Directive 2006/73/EC, art 35(2) and 36.

450 Directive 2004/39/EC, art 24(1). 


\begin{tabular}{|l|l|l|}
\hline & $\begin{array}{l}\text { Procedures for } \\
\text { prompt execution }\end{array}$ & $\begin{array}{l}\text { Procedures for } \\
\text { prompt execution }\end{array}$ \\
\hline Execution-Only & $\begin{array}{lr}\text { Most favorable } \\
\text { execution } \\
\text { Procedures for } \\
\text { prompt execution }\end{array}$ & $\begin{array}{l}\text { Most favorable } \\
\text { execution foredures for } \\
\text { prompt execution }\end{array}$
\end{tabular}

While these categories set out the framework for the standard of conduct of investment intermediaries, they are not excessively rigid; generally, the client has the option to ask for a higher or lower level of protection, though there might be some limitations. For example, eligible counterparties may request, either generally or on a trade-by-trade basis, to have the financial intermediary subjected to the general standard of conduct regime; ${ }^{451}$ professional investors may also wish to be treated as retail investors. ${ }^{452}$ Moreover, retail clients who comply with some requirements may request to be treated as professional clients. ${ }^{453}$

A brief comparison of the American and EU systems on financial intermediary standards of conduct and liability shows that the EU system, while it is quite complex, is more straightforward and less confusing than the American system; the latter seems to suffer from a pathological regulatory overburden created by the imposition of two different systems of regulation that apply to theoretically different institutions but that in practice provide virtually the same services, the difference being only the (self)determination of classification. As the focus in the EU system is on the service provided rather than on how the institution is classified, absent the requirements for a lesser standard of conduct, the higher standard will be applicable, guaranteeing a higher legal certainty in respect of the market regulation operation and the standards of conduct

\footnotetext{
451 Directive 2004/39/EC, art 24(2).

452 Directive 2004/39/EC, Annex II, I.

453 Directive 2004/39/EC, Annex II, II(1).
} 
that should be followed; this consequently establishes a more homogeneous level of protection for investors and creates less confusion for financial intermediaries.

In the European context, it is important to bring attention to the fact that even though the standards of conduct that are expected from the financial intermediaries are the same, as they have been harmonized by European legislation, the specific imposition of liability regarding the non-compliance with these norms is left to Member States since no provision is made in the MIFID Directive; this creates a different regime for the private enforcement of these rules depending on which specific Member State law will be applicable. ${ }^{454}$ There is an ongoing discussion regarding the extent to which the MIFID standards displace private law in EU Member States, as the directive was created as supervision legislation. ${ }^{455}$ The trend seems to indicate that MIFID can also be a basis for private law litigation, complementing national private law standards, even though it still is not clear whether this is mandatory outcome as a matter of EU law, leaving Member States with a considerable margin of discretion regarding their private liability regime. ${ }^{456}$

Finally, in Brazil, the manner in which the regulatory structure is set up is similar to the one in the United States, since it is divided according to the category in which the person is registered in the regulatory system. They are two categories: 1) autonomous investment agents, who perform client prospection activities, amongst others, and provide information about the investment products and services being offered, 457 and 2) investment consultants, who can manage their client's portfolio. ${ }^{458}$ Autonomous investment agents have to act diligently and with good faith, acting with the care of a professional in his position towards his clients and the institutions of the securities

\footnotetext{
${ }^{454}$ See Case 604/11 Genil 48 SL v Bankinter (EC) $4^{\text {th }}$ Chamber, 30 May 2013), para 59.3 ('it is for the internal legal order of each Member State to determine the contractual consequences where an investment firm offering an investment service fails to comply with [the suitability and appropriateness standards], subject to observance of the principles of equivalence and effectiveness').

${ }^{455}$ Cherednychenko 927-31 (n 238).

${ }^{456}$ For a discussion on the issue, see Danny Busch, 'Why MiFID Matter to Private Law - the example of MiFID's impact on an asset manager's civil liability' (2012) 7 Capital Markets Law Journal 386; Stefan Grundmann, 'The Bankinter Case on MIFID Regulation and Contract Law' (2013) 9 European Review of Contract Law 267.

457 Instruction CVM 497, Art 1, I and III.

458 Instruction CVM 306, Art 2.
} 
markets. ${ }^{459}$ A person may not be both an autonomous investment agent and an investment consultant at the same time; he must choose one of the activities. ${ }^{460}$ The problem is that, at the moment, it is not clear what kind of activity would fall within the scope of a consultant, and in any event, it is not clear whether there is a different standard of conduct for each type of classification. However, at least, in Brazil, there is less confusion than in the United States about what type of service is being provided at a given moment, since it is not possible for a person to have a double registration.

This section has demonstrated that the standards of care that are owed in financial intermediary-investor disputes are quite different depending on the jurisdiction at hand. Moreover, even in the EU with its harmonized regime, the actual enforcement of the rules by private parties can vary since the liability regime is left to the Member States.

\section{Legal Framework for Securities Liability - Informational Intermediaries}

The third type of disputes that investors may have in securities transactions are those related to the information providers with whom they do not have a direct relationship, such as Credit Rating Agencies and Auditing Firms. These are market players that provide information to the market and currently are an essential service provider in many securities regulation frameworks, with a legal mandate that changed their status from being mere information providers to market gatekeepers, to the extent that their use is mandatory for certain types of transactions. ${ }^{461}$

The role of these players in the market is a simple one - to provide information to investors so they can make better investment decisions, be it through the provision of an analysis of a given financial product, a service provided by the Credit Rating Agencies, or

\footnotetext{
${ }^{459}$ Instruction CVM 497, art 10.

460 Instruction CVM 497, art 13, para 1.

${ }^{461}$ For a development on the regulatory role of CRAs and the obligation of certain institutions to purchase only rated investments, see footnote 161 of Nan Ellis, Lisa Fairchild and Frank D'Souza, 'Is Imposing Liability on Credit Ratings Agencies a Good Idea?: Credit Rating Agency Reform in the Aftermath of the Global Financial Crisis' (2011-2012) 17 Stanford Journal of Law, Business and Finance 175, 213.
} 
the lending of their 'reputation' to financial statements and guaranteeing that they are correct, as in the case of the service provided by financial auditors.

The legal status of the opinions and statements of these players is relevant to investors; depending on how they are treated and the relevant standard of liability in case the opinion or information is wrong, investors may be able to successfully sue .

In the beginning, CRAs and Auditors developed their services to provide investors with information at a lower cost, either by providing the service directly to the client, as in the case of the initial practice of CRAs of selling subscriptions to their newsletters, or through the provision of audits hired by audited companies and the reputational stamp that the audit would bring. The market developed because there was value to be provided by these market actors, which could only be sustained if the information they provided was more or less accurate, as inaccuracy of ratings or audits would put these information providers out of business.

Later, these players were given a special legal status, as was the case for the Nationally Recognized Statistical Rating Organization (NRSO) status for the CRAs, or the SEC registered status for auditors, because it became a government policy that information provided to investors was presumably relevant. The only reason for the existence of this obligation was a belief that certified financial statements would reduce the probability of false or misleading information.

Under both schemes, informational accuracy is an objective to be achieved, and the system of incentives to which these information providers are subject has to be calibrated to allow them to provide investors with accurate information.

There are two ways to align interests: compensation and liability. In an economic environment, an action will be performed according to the gains that the actor might obtain from the action. Most professional activities on securities transactions arose out of the necessity of information intermediation, such as credit rating agencies and auditing companies. Initially, these practices were developed based on the reputation of the persons involved, who could only market and sell their professional activity to the extent that they were trustworthy. Without it, these parties would not be able to sell their services, as they would not be deemed reliable and thus have no economic value to those who were in need of information. The second aspect of interest alignment is liability. Even 
if the compensation structure would work towards the alignment of interests between information intermediaries and information users, liability, be it in contract or in tort, constitutes another layer of interest alignment design. This section discusses: a) the transformation of the compensation structure of this industry and b) the importance of a liability regime for informational intermediaries.

\section{A. Compensation}

In 1909, the activity of rating securities started with John Moody rating U.S. railroad bonds that had already been in existence since 1850.462 The emergence of credit rating agencies was a convergence of the activities of credit reporting agencies, the specialized financial press and investment bankers, with each having their own particular role in providing financial information. ${ }^{463}$ Compensation in the industry was straightforward: those who wanted to obtain financial information prepared by the rating agencies would subscribe to their services, which would be made available through periodic publications. ${ }^{464}$ The rating agencies then had an incentive to provide the most accurate information as they could by doing analysis in a manner that could reflect reality and provide useful information to their clients, since they would be hired on the basis of their reputational capital. ${ }^{465}$

The change in the industry's compensation scheme occurred in 1970, when issuers started paying rating agencies to rate bonds, an activity which today constitutes the main source of income for rating agencies. ${ }^{466}$ This modification of the CRA business model was a direct effect of securities regulation within the CRA activities domain, after CRAs were elevated to the status of NRSROs and were given the power to grant 'regulatory

462 Richard Sylla, 'A Historical Primer on the Business of Credit Rating Agencies' (The Role of Credit Reporting Systems in the International Economy) 6-7. For a general overview on the development of Credit Ratings, see Frank Partnoy, 'The Siskel and Ebert of Financial Markets?: Two Thumbs Down for the Credit Rating Agencies' (1999) 77 Washington University Law Quarterly 619.

463 Credit Reporting Agencies provided information about the creditworthiness of businesses, the specialized financial press provided information about specific industry sectors and investment bankers provided internal information from a business, usually by being part of the company's board. Sylla 7-10 (n 462).

464 Partnoy 640 (n 462).

${ }^{465}$ See ibid 627-55.

466 Sylla 24 (n 462). 
licenses'. ${ }^{467}$ One of the most important regulatory changes that had an effect in this business model was the requirement that certain investors could only invest in 'safe' assets, which would be classified as such according to a rating from one of the CRA. Issuers would then start to pay CRAs to rate their products, as they would want to be able to access this restricted investor market. The change in the compensation structure clearly also reflected a change of the client being served and the product being provided. The initial client was the user of financial information and the product was high-quality information; after this shift, the client became the issuer and the product became the highest rate possible within the models used by the rating agency. Regulation in this case has transformed the CRA market completely, as all issuers are now legally obliged to have a high rating to be able to tap a given market, incentivizing the practice of gaming the CRA models and, in the worst cases, even corrupting CRAs outright so that every product receives a rating that would comply with the minimum requirements; this results in a situation where even the not so good products receive the necessary rating. ${ }^{468}$

This brief discussion shows that in the first business model scheme the CRA interests are aligned with those of the information users, who are in fact also their clients; in the second case, where there is a regulatory license that the CRAs can use to extract rent from issuers, the interests of CRAs are not aligned with those of the information users, leading to a deterioration in ratings quality. 469

The auditing industry also experienced a similar development; emerging as information intermediaries in colony times, ${ }^{470}$ the industry was later granted regulatory licenses and made legally essential to securities transactions. ${ }^{471}$ In the same way as the

467 Partnoy 623; 83-94 (n 462). See also Claire A. Hill, 'Regulating the Rating Agencies' (2004) 82 Washington University Law Quarterly 43, 43.

468 I do not claim that ratings are, as a matter of fact, of lower quality. The claim is only that there is an incentive for them to be of lower quality.

${ }^{469}$ It is true that even in the first case, if the benefits from a higher rating surpass the costs of capturing a CRA, issuers may decide to pay CRAs or their employees to issue higher ratings, even though this practice might hurt the very basis of the CRAs business, which is selling credibility to information users.

470 See Dale L. Flesher, Gary John Previts and William D. Samson, 'Auditing in the United States: a Historical perspective' (2005) 41 Abacus 21.

${ }^{471}$ For example, in the United States public companies need to have their accounts audited by independent auditors. E.g., Securities and Exchange Act 1934, s 13(a)(2). 
credit ratings market, the market for audited financial statements, based on the reputation of auditors, became a market for certified financial transactions.

In a manner that differs from the CRAs, the conflict of interest in the auditing industry did not arise exclusively from the regulatory license granted by the government. In the U.S. history of auditing, U.K. investors initially used auditors to certify that economic activities taking place overseas were being performed properly. ${ }^{472}$ As the economy grew and capital markets developed, auditors were increasingly hired by securities issuers to increase the reliability of their financial statements. ${ }^{473}$ At this point, the conflict of interest between the auditor and the information user was already more acute than before, since the party remunerating the auditor was no longer the party using its information. Nonetheless, the business continued to be based on reputation, since any credibility that an auditing firm could attribute to a financial statement from an unknown or unreliable company was the credibility of the auditing firm itself, giving it an incentive to perform a thorough audit service.

In a similar fashion to the experiences of the CRA industry, where it became required that every single financial statement must be audited, ${ }^{474}$ and where it became increasingly difficult for an accounting firm to be considered a public accounting firm that can perform audits, regulation operated to guarantee a perpetual market to those that were already in the industry. At the same time, since the number of audits is now more or less guaranteed and since competition is not likely to arise, regulation removes an important incentive for auditors to maintain their reputation.

As the objective of information intermediaries is to provide reliable information, the regulatory changes that were made to the industries of the sector were, to a certain extent, prejudicial to this objective. As compensation might not be the main driver of information accuracy in respect of the services provided by information intermediaries, liability standards and the risk of being held responsible for an information inaccuracy

\footnotetext{
472 Flesher, Previts and Samson 24-26 (n 470).

473 See Paul Healy and Krishna Palepu, 'Information Asymmetry, Corporate Disclosure, and the Capital Markets: A Review of the Empirical Disclosure Literature' (2001) 21 Journal of Accounting and Economics $405,415$.

${ }^{474}$ E.g., Securities and Exchange Act 1934, s 13(a)(2).
} 
has become an important aspect of guaranteeing that the information reaching investors is accurate.

\section{B. The Liability Regime}

The problem in the case of informational intermediaries is that liability is more complicated to establish therein than in the case of issuers and financial intermediaries, as there is no direct legal relationship between the investor and the informational intermediary; in a general liability system, it would fall in the tort category.

In the United States, the situation was even worse for the investor who had relied on a credit rating; CRAs were considered to have the same level of protection for their ratings as journalists had for their news, and could only be held liable for their ratings if plaintiffs could show 'actual malice' by the CRA, ${ }^{475}$ even in cases where the issuer was suing the rating agency in respect of ratings for which it had contracted. ${ }^{476}$ By 2003 , this requirement was softened and some American courts started excluding CRAs from the legal protection that was afforded to news companies in cases in which issuers constituted their clients or were involved in the transaction being rated. ${ }^{477}$

The level of protection that the CRAs had was lowered even more following the Dodd-Frank Act, which required, for purposes of pleading, that the sufficient state of mind for CRA liability is one of knowingly or recklessly failing, '(i) to conduct a reasonable investigation of the rated security with respect to the factual elements relied upon by its own methodology for evaluating credit risk; or (ii) to obtain reasonable verification of such factual elements [...] from other sources that the credit rating agency considered to be competent $[. .]. '{ }^{478}$ In addition, the act also repealed the protection that CRAs had against expert liability in registration statements. ${ }^{479}$ This led CRAs to refuse to accept the inclusion of their ratings in registration statements, which created a stoppage in the

475 See Dun \& Bradstreet, Inc. v. Greenmoss Builders, 472 U.S. 749 (1985); N.Y. Times v. Sullivan, 376 U.S. 245 (1964).

476 In re Enron Corp, Sec., Derivative \& ERISA Litigation, 511 F. Supp. 2d 742 (S.D. Tex. 2005).

477 Theresa Nagy, 'Credit Rating Agencies and the First Amendment: Applying Constitutional Journalistic Protections to Subprime Mortgage Litigation' (2009) 94 Minnesota Law Review 140, 151-54.

478 Dodd-Frank Act, s 933 (b).

479 The repeal was of Rule 436(g) of the Securities Act of 1933. 
markets for asset-backed securities. ${ }^{480}$ After some time in which the market was frozen by the new liability standard, the US House Financial Services Committee approved the removal of the expert liability for CRAs. ${ }^{481}$

In other parts of the world, the status of CRA liability and their standard of care in respect of their activities, varies. Contractual claims are almost impossible to go advance, as there are no specific laws other than contract law governing these transactions; in this case, exclusion of liability is a common clause. ${ }^{482}$ Moreover, in tort, it is not an easy task to attach liability to CRAs, as proving causation may be a complicated task. ${ }^{483}$

In the European Union context, a recent regulation enacted in 2013 imposed civil liability on credit rating agencies. ${ }^{484}$ The system is two-tiered: at the European level, liability can be established when the CRA has infringed any of the rules of Annex III of Regulation (EC) 1060/2009, either intentionally or with gross negligence, causing damage to the investor, who has to establish reliance. ${ }^{485}$ To define what these terms mean, national legislation, determined according to the rules of private international law, will be applicable. ${ }^{486}$ This is a minimum harmonization measure, as the regulation allows for further civil liability if national law provides it. ${ }^{487}$

Finally, the last development worth mentioning in respect of CRA liability arose in Australia. In Bathurst Regional Council v. Local Government Financial Services Pty Ltd. ${ }^{488}$ Standard \& Poor's was found liable for one of its ratings based on misrepresentation and negligence claims. An interesting aspect of the decision was that, despite all the language on the documentation disclaiming liability, the CRAs were held liable due to the function

\footnotetext{
480 Brigitte Haar, 'Civil Liability of Credit Rating Agencies - Regulatory All-or-Nothing Approaches between Immunity and Over-Deterrence' 2013-02 University of Olso Faculty of Law Legal Studies Research Paper Series 1,8 .

481 Ibid 8-9.

${ }^{482}$ Except in France, in which the Finance and Banking Regulation Law forbids this kind of clause. See ibid 3.

483 Ibid 5-6.

484 Regulation (EU) 462/2013 amended Regulation (EC) 1060/2009 and introduced article 35a.

485 Art 35a(1).

486 Art 35a(4).

${ }^{487}$ Art 35a(5).

488 (No 5) [2012] FCA 1200.
} 
that they performed in the markets. As their role is to provide information to investors, ${ }^{489}$ it was decided that they owe a duty of care to potential investors. ${ }^{490}$ This approach to CRA liability, if adopted elsewhere, will have an important impact on the industry, realigning CRA interests to those of the external users of information.

On the auditors' side, liability follows either the securities liability regime standards, with slight modifications in the specific case of auditors, or more general tort law in civil law countries - sometimes with certain limitations, as in Spain - but nonetheless following the logic of general tort law. ${ }^{491}$

In the United States, the standard required to hold an auditor liable for misstatements is even higher in securities transactions than that imposed on other players. In addition to other pleading requirements, to properly plead scienter ${ }^{492}$ in an auditor liability case, the plaintiff 'must allege sufficient facts to show that the accounting practices were so deficient that the audit amounted to no audit at all, or an egregious refusal to see the obvious, or to investigate the doubtful, or that the accounting judgments which were made were such that no reasonable accountant would have made the same decisions if confronted with the same facts'. ${ }^{493}$ The standard for pleading a strong inference of scienter could be met when allegations of red flags coupled with GAAP or GAAS violations are made, ${ }^{494}$ as long as they can show that the auditor's practice amounts,

${ }^{489}$ In a passage, the judge explains that ' $\mathrm{t}$ ] he issuer of the product is willing to pay for the rating not because it may be used by participants and others interested in financial markets for a whole range of purposes but because the rating will be highly material to the decision of potential investors to invest or not. S\&P knew this was why it was being paid which is why it authorised ABN Amro to disseminate the rating in its ratings letters'. Bathurst Regional Council v. Local Government Financial Services Pty Ltd (n 488) 2480.

490 Bathurst Regional Council v. Local Government Financial Services Pty Ltd (n 488) 2819.

491 Another example is Belgium, where liability is not limited. See Ingrid De Poorter, 'Auditor's Liability Towards Third Parties within the EU: A Comparative Study Between the United Kingdom, the Netherlands, Germany and Belgium' (2008) 3 Journal of International Commercial Law And Technology 68, 73 ('By virtue of article 140 of the Belgian Company Code and the common liability principles, a Belgian auditor is liable towards each interested party').

492 As seen before, scienter is the state of mind of the defendant.

493 In re Scottish Re Group Securities Litigation, 524 F. Supp. 2d 370, 385 (S.D.N.Y. 2007) (quoting In re Refco, Inc. Sec. Litig., 503 F. Supp. 2d, 611, 657 (S.D.N.Y. 2007) (internal quotation marks omitted).

${ }^{494}$ See In re AOL Time Warner, Inc. Sec. and “ERISA” Litig., 381 F.Supp.2d 192, 240 (S.D.N.Y.2004) (citing In re Complete Mgmt. Inc. Sec. Litig., 153 F.Supp.2d 314, 334 (S.D.N.Y.2001). 
at best, to a pretend audit. ${ }^{495}$ Auditor protection from liability seems to be a trend in common law jurisdictions; in the UK, it is also complicated to hold an auditor liable; '[absent] special circumstances, an auditor of a public company owes no duty of care to an outside investor or an existing shareholder who buys stocks in reliance on a statutory audit.' 496

At the EU level, there has been an ongoing discussion about auditor liability, but so far no concrete actions have been taken; rather, the focus on solutions falls at the Member State level. ${ }^{497}$ In Spain, for example, the law regulating auditors changed in 2011, through the Royal Legislative Decree 1/2011. The new law provides that liability will be imposed for harm caused by auditing firms due to the breach of their obligations as imposed by the civil code. 498 This law regulates the extent of the liability, rendering it proportional to the direct harm that the accounting firm could have caused to the audited entity or to a third party (e.g. investors) and excluding the harm caused by the audited company. ${ }^{499}$ Finally, the auditors signing the auditing statements are put on the same level as the auditing firms, thus being liable to the same extent. ${ }^{500}$ This is a change from the previous liability system, where responsibility was joint and direct. 501

The Brazilian system can be characterised as even more 'general'; the law regulating the liability of independent auditors only provides that auditing firms will be liable, by willful or negligent conduct, for the harm they cause in exercising their auditing

495 Rothman v. Gregor, 220 f.3d 81, 98 (2 ${ }^{\text {nd }}$ Cir. 2000) (citing McLean v. Alexander, 599 F.2d 1190, 1198 (3 ${ }^{\text {rd }}$ Cir.1979)).

496 Poorter 70 The case in which the comment was made is Caparo Industries v. Dickman and others [1990] 1 All ER 568; AC 605. See also Al Saudi Banque v Clarke Pixley, [1990] Ch 313; James McNaughton Papers v. Hicks Anderson Court [1991] 1 All ER 134.

${ }^{497}$ For an overview of the discussion, see Commission Recommendation Concerning the Limitation of the Civil Liability of Statutory Auditors and Audit Firms - Impact Assessment SEC(2008) 1974.

${ }^{498}$ Art 22.1.

${ }^{499}$ Art 22.2.

${ }^{500}$ Art 22.3.

${ }^{501}$ Art 11 of the previous Financial Audit Law (Law 19/1988). For the movement to change the auditor's liability system in Spain, see Christopher Humphrey, María Antonia García Benau and Emiliano Ruiz Barbadillo, 'El Debate de la Responsabilidad Civil de la Auditoría en España: la Construcción del Discurso sobre la Limitación de Responsabilidades por las Corporaciones Profesionales' (2003) XXXII Revista Española de Financiación y Contabilidad 1091. 
duties. ${ }^{502}$ This law does nothing more than to borrow from the general tort regime existing under Brazilian law.

Even though CRAs and auditors perform similar functions in the market, the liability regimes to which they are subject are different: moreover, the differences between regimes within these two industries are also dependent on the laws of the specific country.

The focus of this section has not been the discussion of what liability regime for third parties is better, 503 but rather to establish that there are many industry-specific and country-specific differences.

\section{Concluding Remarks}

The objective of this chapter has been to identify the types of disputes that may arise out of securities transactions, the standards of conduct in different countries to which the relevant persons involved are subject and the important aspects of the liability regime in each legal system.

The types of disputes differ depending on the legal relationship that the investor has with the defendant. The issuer-investor dispute arises mainly out of securities law, being based on the information disclosure duties that issuers owe to investors. The financial intermediary - investor dispute is the relationship arising out of the contractual relationship between the financial intermediary who is buying or selling a security to the investor, where either suitability or fiduciary duties may play a role in the litigation. Finally, the last category of disputes are those involving information intermediaries, such as CRA and auditors, who do not have a contractual relationship with the investor and are subject to duties arising mainly out of a general tort framework, if at all, notwithstanding the increase in the discussion regarding the need to impose liability on these actors.

\footnotetext{
502 Law 6.385/1976, art 26, para 2.

503 For the discussion of the CRA, see Nagy ( $n$ 477) and Haar (n 480); for the discussion on auditor's liability, see Eric L. Talley, 'Cataclysmic Liability Risk among Big Four Auditors' (2006) 106 Columbia Law Review 1641; Hassen T. Al-Shawaf, 'Bargaining for Salvation: How Alternative Auditor Liability Regimes can Save the Capital Markets' [2012] 2012 University of Illinois Law Review 502.
} 
The relevance of these dispute categories for dispute resolution methods is related to the type of legal connections that the players have with each other. Investors and issuers, at some point in their relationship, had a connection through the securities that had been purchased or sold: there was a direct legal link between the two. The same is true with the investor and the financial intermediary, who are bound by a contract. In the last case, unless the investor is subscribing for credit ratings or hiring the auditor himself, there is no direct legal connection between the parties, leaving liability to be established through general tort law or regulatory law.

Different regulatory regimes with different liability frameworks have important consequences for cross-border transactions: in this situation, legal certainty can only be achieved if a strong private international law mechanism is in place. This is true also in the European Union; even though their standards of conduct is highly harmonized for the different areas of securities regulation, the regulation of the liability aspects are left to the Member States, creating different frameworks for private enforcement that are dependent on the law applicable to the transaction.

The next chapters will explore the dispute resolution design for each type of dispute, the shortcomings that these systems have in a transnational environment and the possible solutions that can be designed for a more simple dispute resolution system. 


\section{Part III - Dispute Resolution}

Legal disputes are nothing more than umpired battles. The courtroom is the forum in which both parties will engage in arguments and present their case, and the judge, according to a specific set of rules, will lead the development of the dispute and decide who is right, imposing a decision on the parties. Each dispute resolution system has its own characteristics and rules of procedure with which the parties must comply, varying to a greater or lesser degree depending on the similarities of the legal systems in which they are embedded.

The rules and institutions in place are paramount to the specific outcome of the dispute. Procedural rules may weigh heavily on who will win; the institutional framework in place is also important with regards to how the procedure will be conducted and enforced. The very core of the Rule of Law itself and the function of law in society are both dependent on the mechanisms of dispute resolution.

Until not long ago, the United States courts were seen as a very attractive forum for plaintiffs who wished to pursue securities litigation, both to Americans who were already familiar with their class action system but also increasingly to foreigners, who were bringing claims that had little connection with the United States. 504

As this movement was unfolding so too was the development of the American battlefield for securities litigation. In the last two decades, domestic plaintiffs have been consistently losing the 'high ground' through increased procedural hurdles, ${ }^{505}$ while more recently, some foreign plaintiffs have been shut out of the system completely. ${ }^{506}$

\footnotetext{
504 The most interesting scenario is the 'foreign-cubed' class actions, where foreign plaintiffs sue foreign issuers for securities bought in foreign markets. For a review of 'foreign-cubed' class actions see Hanna L. Buxbaum, 'Multinantional Class Actions Under Federal Securities Law: Managing Jurisdictional Conflict' (2007-2008) 46 Columbia Journal of Transnational Law 14.

505 The main U.S. Congress acts changing the landscape for securities litigation were the Private Securities Litigation Reform Act of 1995, the Securities Litigation Uniform Standards Act of 1998, and the Class Action Fairness Act of 2005, Pub. L. No. 109-2, 119 Stat 4.

506 In Morrison v National Australia Bank, 561 U.S. 247 (2010), decided in 2010, the US Supreme Court found that Section 10(b) of the Securities and Exchange Act of 1934 'does not provide a cause of action to foreign
} 
At the same time as the U.S. and its courts steps down as the world forum of securities disputes, the discussion shifts to the use of other forums and the use of other mechanisms such as arbitration, 507 which is not only already a possibility in some countries, ${ }^{508}$ but has become institutionalized in others. ${ }^{509}$

These developments have an important effect on the framework for the private litigation of securities disputes, also affecting the role that it plays in securities regulation. Both the private and public enforcement of securities laws are important in order to promote the efficiency of the market, enhancing the added value that these activities can provide. ${ }^{510}$ As seen in Chapter $\mathrm{V}$, the basic argument for private rights and their enforcement is that it promotes investor confidence, making markets stronger and enhancing competition for financial services providers, which in turn leads to a lower cost of capital. 511

The strength of the market and the amount that investors that have been misled may recover has a strong relationship to the design of the dispute resolution system in place, which allows them to adjudicate their claims. The objective of the last part of this thesis is to analyze different designs of dispute resolution mechanisms, both nationally and transnationally, to assess their advantages and shortcomings in respect of the different types of disputes and finally, to propose mechanisms to improve the current infrastructure.

plaintiffs suing foreign and American defendants for misconduct in connection with securities traded on foreign exchanges'.

${ }^{507}$ See Richard Shell, 'Arbitration and Corporate Governance' (1989) 67 North Carolina Law Review 517; Interim Report of the Committee on Capital Markets Regulation (30 November 2006); McKinsey \& Co., Sustaining New York's and the U.S.' Global Financial Services Leadership (22 January 2007); Christos Ravanides, 'Arbitration Clauses in Public Company Charters: an Expansion of the ADR Elysian Fields or a Descent into Hades?' (2007) 18 The American Review of International Arbitration 371.

508 Brazil and Spain are two jurisdictions where arbitration is expressly allowed in corporate charters, encompassing securities matters. See respectively Law 6.404/1976 (Brazil) art 109, §3o and Law 60/2003 (Spain), art 11 bis.

509 In the United States, securities disputes with brokers and dealers are usually solved under the framework of FINRA, and not through courts, while in Brazil companies listed in higher corporate governance levels in Bovespa need to have an arbitration clause in their corporate charter; the institution that is usually used is the Câmara de Arbitragem do Mercado.

510 See Section II below for a discussion on the role of private and public enforcement in securities regulation. 511 World Bank, Institutional Foundations for Financial Markets (2006) 3. 


\section{Chapter VI - Institutional Aspects of Dispute Resolution}

So far this thesis has tried to establish the importance of the private enforcement of investor protection in securities transactions and of the efficiency of financial markets. This chapter moves away from the focus on financial markets and the justification of private enforcement and enters into the discussion of dispute resolution mechanisms. Its objective is to explain the institutional framework of a dispute resolution system and to analyze the policy choices that can be made in respect of its design. The question to be answered is 'what are the relevant aspects that have to be considered on the design of a dispute resolution system?'

By answering this question, it is possible to establish a framework that will be (loosely) used for the analysis developed in the next two chapters; these chapters have a specific focus on dispute resolution systems in general (Chapter VII) and on systems which use aggregate litigation (Chapter VIII).

For the purposes of this analysis, there are two categories of institutional aspects that have to be considered: the legal aspects and the economic aspects of a dispute resolution system. The legal aspects define the political and legal structures within which the dispute resolution system is embedded, while the economic aspects define the means through which the system will finance itself, engaging at the same time with the question of incentives to litigate. This second economic aspect is especially relevant as it relates directly to the efficiency of the system and the procedural level of protection that is given to litigants.

These institutional aspects are essential for the construction of a dispute resolution system. These legal and economic aspects give shape to the structure of the system and are their minimum necessary components. Therefore, this chapter is divided into two parts: 1) legal aspects of the institutional framework and 2) economic aspects of the institutional framework. 


\section{Legal Aspects of the Institutional Framework}

In respect of the legal aspects, it is important to anchor the discussion in the premise that any dispute resolution system is tied to the legal framework of the state. This is a necessary condition of its existence because, without the power of the state, the dispute resolution system would either be ineffective absent the will of the losing party to comply with the decision or it would make any attempt of enforcement illegal. ${ }^{512}$ The legitimacy of the system and the legal framework underpinning its operation therefore becomes essential to justify its binding effects.

In addition, to provide a just method for dispute resolution, the decision makers have to be independent, while at the same time the logic in which their decisions are reached has to be made known, allowing society to develop legitimate expectations on the rules of the legal system. ${ }^{513}$

These institutional legal aspects are necessary for a system based on the Rule of Law, which has important consequences in respect of the mechanisms underpinning the economic organization of society.

\section{A. The Legal Basis of the Dispute Resolution System}

Since the legal power of a dispute resolution system has to be linked to the legal system in which the decision arising out of it has to be enforced, the legal basis of the system becomes an important aspect for its design. The legal basis for the authority of a dispute resolution system can either have a direct link to the state's power or it can be indirect, having an extra requirement for legality to operate. At the same time, the dichotomy of the pure jurisdictional basis/consent jurisdictional basis defines the transnational legal infrastructure that is available for the cross-border operation of dispute resolution systems. This section explains each of them.

\footnotetext{
512 Unless the legal system authorizes private deployment of force to guarantee one's rights.

513 The conception of just used here is a formalistic one - a just decision is one that is or could be reasonably expected in a given legal system.
} 


\section{a. Pure Jurisdictional Basis}

The main dispute resolution system with a pure jurisdictional basis is the judiciary. As a part of the state structure and normally created and designed by a constitution, the judiciary is in charge of solving every type of dispute. It is the institution that applies and maintains the law.

Its main characteristic is that it is a direct part of the state structure; judges are authorized to decide matters that are brought to them independently of the will of the parties of the dispute. It does not matter that one of the parties does not wish to be bound by the decision; as long as the requirements to make the party part of the legal procedure are satisfied, the judge may decide the dispute and the decision will be legally enforceable.

Even though the court structure is the main body with a pure legal jurisdictional basis, it may not be the only one. Alternative dispute resolution arrangements can also be created on the basis of pure jurisdictional powers. Within this idea, the important characteristic of pure jurisdiction is the possibility of binding decisions without some prior authorization of the party being bound.

Systems built on a pure jurisdictional basis are either constitutionally designed or created by legislation, always having support from the state that is attributing jurisdiction to it. This implies that in order to be created or modified, these systems require political energy.

Another problem is the effects that decisions based on pure legal jurisdiction have on foreign jurisdictions. Today there is no wide-ranging mechanism for the recognition of foreign judgments, creating piecemeal solutions, or none at all, for cross-border dispute resolution. ${ }^{514}$

\section{b. Consent Jurisdictional Basis: Arbitration}

Systems with consent jurisdictional basis require not only the authorization of the legal system but also the consent of the parties in submitting their dispute to it. This is the

\footnotetext{
${ }^{514}$ Attempts were made to create an international convention on jurisdiction and judgments (The Hague Convention on Jurisdiction and Judgments) but the efforts were unsuccessful. See Ralf Michaels, 'Two Paradigms of Jurisdiction' (2006) 27 Michigan Journal of International Law 1003, 1009-10.
} 
premise of arbitration, which is the use of a private third-party to decide a dispute between two litigants, binding them as to the outcome. ${ }^{515}$ Arbitration is a creature of consent. Parties are bound by it if they have agreed to the dispute resolution mechanism that settles their dispute. In addition, only those matters that are authorized, or not prohibited by law, can be arbitrated; as such, not all disputes can be decided via arbitration.

The practice of employing third parties to solve disputes through the application of rules pervades ancient history. From the Middle East to Rome, there are many accounts of parties designing their dispute resolution methods and using third parties to give a binding decision on their dispute. 516 It is true that the institutional setting of arbitration as we know today was only possible after the development of the modern nation-states, creating the interplay between public and private that permeates this dispute resolution process. 517

Even though there is an extensive body of literature that sees arbitration as a kind of lex mercatoria, the efficacy of an arbitral award depends on the legal framework in which it will be enforced; therefore, both the national legal state infrastructure and the international one, are essential to consider the use of arbitration. ${ }^{518}$

Arbitration therefore has two levels of legitimacy: the first is the legal authorization allowing parties to empower a third-party to decide their dispute with finality, while the second is the agreement between the parties to empower the third-

515 Orley Ashenfelter and Radha Iyengar (eds), Economics of Commercial Arbitration and Dispute Resolution (Edward Elgar 2009) ix.

516 See Gary Born, International Commercial Arbitration (Kluwer Law International 2009) 21-27. Such practice was also common during the Middle Ages, where it had a relevant role in guilds and trading places. See John Baker, 'From Lovedays to ADR: Arbitration and Dispute Resolution in England 1066-1800' [2006] 2006 Transnational Dispute Management 1.

517 Arbitration during the $18^{\text {th }}$ and $19^{\text {th }}$ centuries faced strong hostility from some states; in France this started to change only after its ratification of the Geneva Protocol of 1923, which made agreements to arbitrate enforceable, while in the United States, this hostility was only overcome with the enactment of the Federal Arbitration Act and similar state rules. See Born 37-49 (n 516).

518 ' [...] international commercial arbitration, no less than arbitration within nation-states, while conducted in the sphere of private law, is a public legal creation whose operation and effectiveness is inextricably linked to prescribed actions by national courts', W. Michael Reisman and Brian Richardson, 'Tribunals and Courts: An Interpretation of the Architecture of International Commercial Arbitration' in Albert Jan Van Den Berg (ed), Arbitration - The Next Fifty Years (Kluwer Law International 2012) 17. 
party. This section briefly surveys some of the legal systems enabling arbitration at the national and the transnational levels.

\section{The National Legal Framework for Arbitration}

Even though arbitration could theoretically be envisioned based only on the legal principle of pacta sunt servanda, it is usually regulated by legislative provisions.

The United States for example has a strong tradition of arbitration. The Federal Arbitration Act was enacted in 1925, ${ }^{519}$ covering both domestic and international arbitration. ${ }^{520}$ It was the result of a movement from the business community in the years before its enactment, which pressed for legislation due to the concern on the costs and delays with litigation and the problems with the enforceability of arbitration agreements. ${ }^{521}$ As it is today, the FAA is a strong statute and preempts most state arbitration laws in the United States if they try to diminish or limit the contractual agreement of the parties to arbitrate, ${ }^{522}$ creating a generous federal arbitration environment. Also, the case law developed in the United States opened up the possibilities of situations in which disputes could be submitted to arbitration, encompassing a wide array of cases. ${ }^{523}$

Arbitration in Spain also has deep historical roots, to the extent that it was considered a fundamental right in the Cadiz Constitution, in $1812 .{ }^{524}$ The institute has suffered various changes since this time, ${ }^{525}$ reaching its current institutional design with Law $60 / 2003$. Inspired by the UNCITRAL Model Law, ${ }^{526}$ the Spanish Arbitration law is a

\footnotetext{
519 Federal Arbitration Act, Ch. 213, § 1, 43 Stat. 883 (1925).

520 Imre S. Szalai, 'The Federal Arbitration Act and the Jurisdiction of the Federal Courts' (2007) 12 Harvard Negotiation Law Review 319, 325.

521 Ibid 354-55.

522 See Christopher R. Drahozal, 'Federal Arbitration Act Preemption' (2004) 79 Indiana Law Journal 393, 407-20.

523 Ravanides 373-74 (n 507).

524 See José Fernando Merino Merchán, 'La Constitución de 1812 y el Arbitraje' (2012) 14 Revista del Club Español del Arbitraje 33.

525 The modifications came with the Civil Procedure Law of 1855, the Jurisdiction Unification Decree of 1855, the Civil Procedure Law of 1881, the Arbitration Law from 1953, the Arbitration Law from 1988, and finally Law 60/2003. Ibid 34-35.

526 Law 60/2003, Exposition of Motives.
} 
modern law, encompassing all the necessary requirements for a strong environment for arbitration.

Brazil, on the other hand, has a much younger arbitration culture. Having taking the same position as most Latin American countries and having embraced the 'Calvo Doctrine' in the past, ${ }^{527}$ Brazil was strongly opposed to the use of arbitration to solve international disputes. ${ }^{528}$ This approach started to change in the 1980 s with the opening up of the Brazilian economy to foreign investment; the development of this area only reached maturity in 2002, with the ratification of the New York Convention. ${ }^{529}$

Meanwhile, the journey to an efficient arbitral framework in Brazil was a turbulent one. The Brazilian arbitration law was enacted in September 1996,530 but soon enough its constitutionality was being challenged as violating article 5 XXXV of the Brazilian Constitution, which provides that 'the law will not exclude from the appreciation of the Judicial Power a harm or threat to a right'. This challenge was only solved in 2001, and until then arbitration clauses were seen as mere promises to arbitrate, without any legal certainty as to their efficacy. The only manner to solve the dispute by arbitration was through an agreement to arbitrate after the dispute had arisen. ${ }^{531}$ With the decision in 2001, the constitutionality of the Arbitration Law was confirmed by the STF, 532 bringing to an end the legal insecurity that was present in the use of arbitration clauses in the Brazilian legal system.

\section{The International Framework for Arbitration}

The first international legal instrument that initiated the development of international arbitration was the Geneva Protocol on Arbitral Clauses of 1923. Ratified by

\footnotetext{
527 The Calvo Doctrine, named after Carlos Calvo, was a foreign policy principle that foreign investors had to use local courts to solve their disputes.

528 Renata Brazil-David, 'An Examination of the Law and Practice of International Commercial Arbitration in Brazil' (2011) 27 Arbitration International 57, 57.

529 Ibid 58.

530 Law 9.307/1996.

531 Brazil-David 58 (n 528).

532 M.B.V. Commercial and Export Management Establishment v Resil Industria e Comercio Ltda (STF, SE 5206 AgR) (2004).
} 
various countries, it was the first truly, wide-ranging instrument backing arbitration. ${ }^{533}$ This Protocol made agreements to arbitrate in connection with contracts valid, even though each country could limit the application of the Protocol to commercial contracts. $^{534}$ Its practical advantage was that the courts of the signatories, when facing a valid arbitration clause, had to refer the parties to arbitration. ${ }^{535}$

As the beginning of the modern framework for international arbitration, this instrument had some important limitations. The Protocol was only applicable when the agreement to arbitrate was made between parties of different jurisdictions, ${ }^{536}$ and through this instrument only Contracting Parties had the duty to execute arbitral awards if they were made within their own territory. ${ }^{537}$ Even with the presence of such limitations, the Protocol was indeed useful to many parties who wished to compel arbitration. $^{538}$

Soon came the second important international instrument for international arbitration, the Geneva Convention for the Execution of Foreign Arbitral Awards of 1927. The Geneva Convention extended the territorial enforceability of arbitration made pursuant to a valid agreement under the Geneva Protocol, increasing the efficiency of the

533 The treaty was ratified by Albania, Austria, Belgium, Brazil, UK and some of its colonies, New Zealand, India, Czechoslovakia, Denmark, Estonia, Finland, France, Germany, Greece, Iraq, Italy, Japan, Luxembourg, Monaco, Netherlands, Norway, Poland, Portugal, Romania, Spain, Sweden, Switzerland and Thailand.

534 Geneva Protocol on Arbitration Clauses, art 1: 'Each of the Contracting States recognises the validity of an agreement whether relating to existing or future differences between parties subject respectively to the jurisdiction of different Contracting States by which the parties to a contract agree to submit to arbitration all or any differences that may arise in connection with such contract relating to commercial matters or to any other matter capable of settlement by arbitration [...]. Each Contracting State reserves the right to limit the obligation mentioned above to contracts which are considered as commercial under its national law.'

535 See Geneva Protocol on Arbitration Clauses, art 4.

536 See Geneva Protocol on Arbitration Clauses, art 1.

537 Geneva Protocol on Arbitration Clauses, art 3: 'each Contracting State undertakes to ensure the execution by its authorities and in accordance with the provisions of its national laws of arbitral awards made in its own territory under the preceding articles.'

538 See Arthur Nussbaum, 'Treaties on Commercial Arbitration: a Test of International Private-Law Legislation' (1942) 56 Harvard Law Review 219, 231-32. 
international arbitral system. ${ }^{539}$ Another positive aspect of the Convention was the limitation of the substantive review of the merits of the awards. ${ }^{540}$

Even though there were improvements in the system, it still was fairly burdensome. The party enforcing the award had to prove that the award was valid, the subject matter was capable of settlement by arbitration under the law of the country it would be relied upon, that the award was made by an arbitral tribunal composed according to the will of the parties, that it was a final award and that its recognition was not contrary to the public policy of the country in which it was to be relied upon. ${ }^{541}$ Such requirements created a double-exequatur situation; the enforcing party firstly had to confirm the award in the country in which it was made before then pursuing enforcement in another country. ${ }^{542}$ These two instruments provided a comprehensive framework for international arbitration in the first half of the XX century, preparing the field for the developments that were about to come.

Due to concerns from the business community regarding the instruments in place backing international arbitration, the International Chamber of Commerce issued a preliminary draft convention with the objective of substituting the Geneva instruments of the 1920s'.543 The main idea behind the project was the creation of truly international awards, in other words, awards that are independent from national rules of procedure where the arbitration took place. 544

This idea of international arbitration completely detached from states was not well considered. The ICC Draft Convention was presented to the United Nations Economic and

\footnotetext{
${ }^{539}$ Geneva Convention for the Execution of Foreign Arbitral Awards, art 1: 'In the territories of any High Contracting Party to which the present Convention applies, an arbitral award made in pursuance of an agreement whether relating to existing or future differences [...] covered by the Protocol on Arbitration Clauses [...] shall be recognised as binding and shall be enforced in accordance with the rules of the procedure of the territory where the award is relied upon [...]'

540 Born 61 (n 516).

541 Geneva Convention for the Execution of Foreign Arbitral Awards, art 1.

542 Born 62 (n 516).

543 International Chamber of Commerce ICC, Enforcement of International Arbitral Awards: Report and Preliminary Draft Convention (ICC Brochure No 174, Paris, 1953).

544 Ibid 7.
} 
Social Council (ECOSOC), who, in 1955, came up with a new Draft Convention ${ }^{545}$ that was closer to the already-established international arbitration system. ${ }^{546}$ This new draft received comments from various governments and non-governmental organizations, ${ }^{547}$ leading to a 'Conference on International Commercial Arbitration' that was held in the United Nations in New York, from May 20 to June 10 in 1958.548 This conference ended with the signature of the New York Convention.

Today, the New York Convention is in force in 149 countries. ${ }^{549}$ Already considered for some time as the 'cornerstone of current international commercial arbitration', 550 it provides a global framework for the recognition and enforcement of arbitral awards and arbitration agreements.

The scope of its application comprises arbitral awards made in the territory of a state other than the one in which the recognition or enforcement is sought or awards not considered domestic in the state in which it is to be recognized or enforced. ${ }^{551}$ By analogy, the same rationale is applicable to arbitration agreements ${ }^{552}$ when the seat is outside of the forum state. ${ }^{553}$ If the seat is in the same state, the applicability of Article II will be subject to domestic law. ${ }^{554}$

${ }^{545}$ See ECOSOC 'Report of the Committee on the Enforcement of International Arbitral Awards' UN Doc E/2704 (28 March 1955).

${ }^{546}$ Albert Jan van den Berg, The New York Arbitration Convention of 1958 (Kluwer Law and Taxation 1981) 7.

${ }^{547}$ See ECOSOC 'Recognition and Enforcement of Foreign Arbitral Awards: Report by the Secretary-General' UN Doc E/2822 (31 January 1956).

${ }^{548}$ Berg 8 (n 546). See also UN Doc E/CONF.26/SR. 1- UN Doc E/CONF.26/SR 25.

${ }^{549}$ See 'Status of the Convention on the Recognition and Enforcement of Foreign Arbitral Awards' (Uncitral) <http://www.uncitral.org/uncitral/en/uncitral_texts/arbitration/NYConvention_status.html> accessed 8 July 2014.

550 Berg 1 (n 546).

551 New York Convention, art 1(1).

552 Recognition and enforcement of arbitration agreements is governed by Article II of The New York Convention.

553 See Dorothee Schramm, Elliott Geisinger and Philippe Pinsolle, 'Article II' in Herbert Kronke and others (eds), Recognition and Enforcement of Foreign Arbitral Awards: a Global Commentary on the New York Convention (Wolters Kluwer Law and Business 2010) 41.

554 Ibid 42. 
The Convention provides specific rules for the recognition and enforcement of arbitral awards and agreements. Under the Convention, an arbitration agreement has to be in writing in respect of a defined legal relationship of which the subject matter can be settled by arbitration. ${ }^{555}$ For the recognition and enforcement of the arbitral award, the plaintiff only has to provide the original award and the arbitration agreement or certified copies of these documents, translated to the language of the court in which recognition or enforcement is sought, if necessary. ${ }^{556}$ These conditions are the only two necessary for the recognition and enforcement of an arbitral award; national implementing legislation requiring more from plaintiff is contrary to The New York Convention. ${ }^{557}$

Compared to the Geneva Convention, the New York Convention presents an important evolution in this aspect, since it is no longer necessary for the plaintiff to prove either that the award is final in the country where it was made or that the arbitral tribunal was constituted in the manner agreed upon by the parties, 558 removing the necessity of the double-exequatur. 559

The burden is now on the defendants, who, to avoid the enforcement of arbitral awards, have to prove one of the grounds available in article $V$, subject to the discretion of the enforcing courts. ${ }^{560}$ Even though the approach to judicial discretion may vary depending where enforcement is sought, in practice the results are similar, independently of the approach taken by the court. ${ }^{561}$

\footnotetext{
${ }^{555} \operatorname{Art~II(1)(2).~}$

${ }^{556} \operatorname{Art} \operatorname{III}(1)(2)$.

557 Berg 248 (n 546).

558 Geneva Convention for the Execution of Foreign Arbitral Awards, art 1 (c)(d).

559 Even though the plaintiff does not have to prove these two aspects, they are still basis for a court to refuse enforcement of an arbitral award. See New York Convention, art V (d)(e).

${ }^{560}$ Article $\mathrm{V}$ reads: 'Recognition and enforcement of the award $\mathbf{m a y}$ be refused, at the request of the party against whom it is invoked, only if that party furnishes to the competent authority where the recognition and enforcement is sought, proof that:'

561 Patricia Nacimiento, 'Article V(1)(a)' in Herbert Kronke and others (eds), Recognition and Enforcement of Foreign Arbitral Awards: a Global Commentary on the New York Convention (Wolters Kluwer Law \& Business 2010) 207-09.
} 
The improvements of the global international arbitration framework introduced by the New York Convention and the number of countries that have ratified it, render it an important component of the discussion of transnational dispute resolutions.

\section{c. Considerations on the Legal Basis of a Dispute Resolution System}

Why does it matter what legal basis is used to design a dispute resolution system for securities transactions? There are two important aspects that arise directly out of this question.

The first is the level of entrenchment of the dispute resolution system within the institutional framework of governments. Nationally or internationally, systems that have a direct legal basis are harder to create and when they are created, they are not so easily dismantled. They are often part of a greater state or inter-state design, such as the judiciary or the WTO.

On the other hand, systems based on indirect legal jurisdictional basis do not need the same political capital to be built. Anyone could start an arbitral institution from their home, as it does not usually require previous approval from the authorities. The success of the system would require convincing those persons who are party to disputes to use them; this however, is more of a marketing question.

The second aspect is the enforcement of the decisions across borders. The direct legal jurisdiction systems often depend on treaties made in a piecemeal basis or on considerations of 'comity' in order to operate across borders, presenting serious legal barriers and legal uncertainty. The indirect legal jurisdiction systems are more effective due to the New York Convention, which allows for the world-wide enforcement of any decision made in such systems. This second aspect will be discussed more in depth in another chapter. ${ }^{562}$

\section{B. The Decision-maker's Independence and Accountability}

In the context of legal decision-making, independence is the absence of external factors influencing the decision-making process, whether from the other political

\footnotetext{
562 See Chapter X.
} 
branches of the state or from private interests. Independence therefore is an essential characteristic of the Rule of Law, since for it to exist, those who are in charge of applying the law have to take their decisions on the basis only of the legal rules and principles of a given legal system.

External influence in the decision-making process in dispute resolution systems is a dangerous path as it jeopardizes the Rule of Law ideal by bringing alien concepts into it. If this is allowed, law becomes pure politics, thus changing all the beneficial aspects that a legal system may play in solving disputes in a just and fair system. ${ }^{563}$ In the modern state context, judicial independence is so important that it is considered to be a fundamental human right. 564 To avoid unwarranted influences ${ }^{565}$ and guarantee independence, formal institutional safeguards have to be put in place. ${ }^{566}$ The adjudicator, as a neutral thirdparty, can only dispense justice and fairness according to the law if there is independence, ${ }^{567}$ and if this is valid both for judges as public officers as well as arbitrators acting through the power delegated by the parties in the dispute.

The flipside of independence is accountability. Too much independence is also problematic, since, if left unchecked, judges may become the tyrants themselves, foregoing the application of the law for their own private interests. ${ }^{568}$ This is a matter of fine-tuning the institutional design of a political system, as judges are the gears in the wider machinery of the state. To the same extent that judges should not be allowed to decide based on bribes, nor should they be allowed to forego what has been politically

\footnotetext{
563 'A legislature required to generalize when crafting its rules will, we fear, be all too quick to abandon or distort those rules in particular cases involving favored or disfavored parties, thus subverting the law's generality for improper reasons.' John A. Ferejohn and Larry D. Kramer, 'Independent Judges, Dependent Judiciary: Institutionalizing Judicial Restraing' (2002) 77 New York University Law Review 962, 967.

564 Universal Declaration of Human Rights, art 10.

565 The influences to be concerned with are the illegal ones - those arising out of private bribes or political pressure, disfiguring the legal process and adding elements for the judge to consider that should be absent for a decision based solely on legal arguments.

566 Georg Vanberg, 'Establishing and Maintaining Judicial Independence' in Keith Whittington, Daniel Kelemen and Gregory Caldeira (eds), The Oxford Handbook of Law and Politics (Oxford University Press 2008) 100.

567 Christopher Larkins, 'Judicial Independence and Democratization: a Theoretical and Conceptual Analaysis' (1996) 44 The American Journal of Comparative Law 605, 608.

568 'Making judges independent of politicians and other lawmakers may free them from certain pressures to ignore the law [...], but it also frees them from any pressure to follow it, and it allows them to make law in ways that could be problematic.' Ferejohn and Kramer 972-73 (n 563).
} 
established as 'law', apart from constitutional violations, within a democratic legal system. ${ }^{569}$ To address this problem, accountability mechanisms have to be created to provide some sort of control over decision makers, who will have different characteristics depending on whether the decision-maker is a public official (direct legal jurisdiction) or an arbitrator (consent-based jurisdiction).

\section{Public Officials}

The judge is the person holding a public office within the political structure of a state. If the state is a democratic one abiding by the Rule of Law standard, the judge's independence has two essential aspects. ${ }^{570}$

The first aspect is that of the judge as a public officer within a state branch vis-àvis the other state branches and his role in guaranteeing compliance with the rules of the political system. In this respect, the judge must be insulated from political pressures from other sectors of the state,, 71 as he is acting as a guarantor that the state will not be able to execute its will outside of what is authorized by law. ${ }^{572}$

Some of the mechanisms to guarantee a judge's independence are a strong selection process, tenure on the job, irreducibility of salaries, ${ }^{573}$ prohibition of transfers, judicial immunity and a country's budget percentage that is guaranteed to the judicial branch. ${ }^{574}$ These mechanisms soften any concerns that a judge might have regarding the continuity of his standard of life and the proper work of the judicial institutions since

${ }^{569}$ The power aspect is not the only relevant problem with judges who are too independent, as the legal uncertainty arising out of such a legal system design has also considerable economic impact due to the uncertainty that this brings into the legal system.

${ }^{570}$ Borrowing from the definition of Christopher Larkins, 'Judicial independence refers to the existence of judges who are not manipulated for political gain, who are impartial toward the parties of a dispute, and who form a judicial branch which has the power as an institution to regulate the legality of government behaviour, enact 'neutral' justice, and determine significant constitutional and legal values.' Larkins 611 (n 567).

571 Ibid 609.

${ }^{572}$ Constitutional courts are an important aspect of limiting a state's power and guaranteeing that some rights will be left unaltered by the state.

573 The salary standard should be linked to its purchasing power since inflation can deeply erode what the judges can effectively obtain from it. See Keith Rosenn, 'The Protection of Judicial Independence in Latin America' (1987) 19 The University of Miami Inter-American Law Review 1, 29-30.

574 Ibid 15-23. 
there is guaranteed income both at a personal and institutional level. By ensuring these guarantees are satisfied, the judges are free to decide as they please, without being afraid of retaliation from other political bodies.

As the fairness of decisions depend on judges deciding based on the law, their independence has to be balanced with other mechanisms that ensure that judges will not stray too far from the possibilities of decision within the legal system and applicable norms of which they are part. The structure of the judiciary itself already presents some accountability mechanisms that counter-balance the judge's independence, such as the right to an appeal. Alongside with it, another incentive for judges to remain within some widely acceptable boundaries of the law is to have the rate of reversal of their decisions, as one of the yardsticks for promotion within the judicial career. An instrument of a more political character that is also used to control the exercise of the Judiciary's power is the possibility of impeachment or the discharge of duties for judges; this is a serious mechanism usually reserved to the most egregious offenses, such as outright corruption. ${ }^{575}$

The second aspect is judicial independence from the external influences of the parties to the dispute. The practice of selling decisions or of deciding on the basis of friendship or family ties (with a party to the dispute) undermines the fairness and justice of the legal system, disrupting the Rule of Law. There are a few measures available to discourage this type of behavior. The first is to give judges sufficient income for the position they occupy in society. Guaranteeing a good income diminishes the incentives underpinning the judge's acceptance of a bribe, to decide in their favor, from one of the parties to the dispute. The second measure is to provide the parties within the procedural system with a way to exclude a judge from a dispute due to the ties he might have with the other party. ${ }^{576}$ Finally, criminalizing corruption is also another means by which the

575 See Frank Thompson Jr. and Daniel H. Pollitt, 'Impeachment of Federal Judges: an Historical Overview' (1970-1971) 49 North Carolina Law Review 87; Supplementary Law 35/1979 (Brazil), art 26.

${ }^{576}$ Ideally this would be done by a second level review mechanism, and not by the judge presiding the case. 
institutional design might be structured to avoid judge partiality and guarantee independence..$^{577}$

\section{Private decision makers}

In the same manner that judges need to be independent and impartial to provide litigants with fair and just decisions, so do arbitrators. In fact, from the perspective of a single dispute, the independence of the arbitrator has to be even higher than that of the judge because in a state-based judicial system appellate review is normally available, what is uncommon in arbitration. ${ }^{578}$ Since arbitration is a matter of choice on the part of those who submit their disputes to it, the parties will necessarily only agree to do so if they believe that there is a certain level of honesty in the process. ${ }^{579}$

Even though the importance of independence for the litigants in a specific case in arbitration may be even higher than in a judicial proceeding, the mechanisms guaranteeing independence from undue influence are not the same as in state structures. This difference between state mechanisms of independence and arbitration mechanisms are due to the different structural relationships that arbitrators and judges have with the parties.

The difference is founded in the identification of the judge or the arbitrator to decide the dispute. In a lawsuit, the party will file a brief that will be randomly distributed to a judge competent to hear the matter. ${ }^{580}$ In other words, even though there might be a pool of judges that can decide the dispute, or only one judge that can decide the dispute depending on the size of the jurisdiction in which the dispute will be heard, the judge is not explicitly chosen by the parties. On the other hand, arbitrators are normally chosen by parties; they either act together, or each party will nominate an arbitrator, and the arbitrators nominate a third.

577 For a general overview on judicial corruption, see Transparency International, Global Corruption Report 2007 (Cambridge University Press 2007).

578 Born 1463-64 (n 516).

579 'The perceived legitimacy of the international arbitration process cannot be greater than the degree of confidence that litigants have in the ethical standards of the arbitrator.' Jan Paulsson, 'Ethics, Elitism, Eligibility' (1997) 14 Journal of International Arbitration 13.

580 E.g., Brazilian Civil Procedure Code, art 252. 
The second difference reflects remuneration. Judges are public employees, and are therefore paid by the government through revenue that is secured from the general population by taxation and sometimes from fees that the litigants pay to the judicial system. ${ }^{581}$ Arbitrators are usually exclusively remunerated by the parties to the dispute, who have to proportionally fund the costs of the dispute resolution process.

Even though judges and arbitrators solve disputes for a living, it is a business only for the arbitrators, since they depend on 'clients' to select them to decide their cases and to generate revenue. This characteristic unpacks a wide array of considerations that are relevant to their independence. At the same time, while it is important to prevent arbitrators from being too close to one of the parties of the dispute, it is also important not to decrease too extensively the requirements authorizing a claim of partiality, since this could lead to problems in finding arbitrators for some disputes, especially in cases that, due to its geographical traits or subject matter, there are not that many arbitrators available. This could be a problem in a field as specialized as securities transactions.

There is no single standard for assessing an arbitrator's independence worldwide, but the one that is commonly used is 'justifiable doubts'. ${ }^{582}$ The concept is used to assess the risk of partiality, since it is not necessary that a party demonstrate an actual lack of independence or impartiality, but only that there is a justifiable doubt in the mind of a reasonable third party. 583 The standard is also coupled with the use of possible conflict disclosure requirements by arbitrators, which if not made, may generate sufficient grounds for disqualification, even if the possible conflict that should have been disclosed is not by itself sufficient for a partiality claim. ${ }^{584}$ With an obligation of disclosure, the parties have a higher awareness of the possible conflicts that the arbitrator may have in deciding their dispute, impeaching the arbitrator if necessary.

581 Only a few countries have a system where what is paid by the litigants is supposed to cover the costs of the justice system. See Christopher Hodges, Stefan Vogenauer and Magdalena Tulibacka (eds), The Costs and Funding of Civil Litigation: a Comparative Perspective (Hart Publishing 2010) 13-15.

582 See UNCITRAL Model Law on International Commercial Arbitration (2006), art 12; IBA Guidelines on Conflicts of Interest (2004), Part I(2).

${ }^{583}$ See Born 1475-79 (n 516).

584 Ibid 1524. 
These mechanisms are important to guarantee the integrity and legitimacy of the arbitration process, helping to lift it to the same level as the public justice system, at least as regards private enforcement.

\section{The Reasoning and Publicity of Decisions}

The reasoning behind legal decisions is an important aspect of any legal system. Law is dynamic, always evolving through new legislation and legal decisions. There are two special aspects of reasoned decisions that are important for a modern legal system: firstly, they constrain the judges in reaching a decision since they are obliged to use reason and the decision has to logically follow from the premises that were accepted in a judgment. If the premises are the ones being disputed, practical reason has to be used through the frame of reference of the law in general or of particular branches of law. ${ }^{585}$ Secondly, they give the legal system new material to operate, clarifying situations that were before unclear and serving as the basis for the discussion and decision of similar cases.

In respect of the first aspect, legal reasoning in a legal system functions as a guidepost for judges as it limits the range of decisions that can be taken. The lack of a reasoning obligation would allow them to reach any decision without having to provide justification. By imposing a duty to reason, judges have to do so through legal arguments, what can be made only according to the logic of the legal system itself. Reasoning therefore has to be developed based on legal norms, with the effect of constraining the possible arguments that can be made, and consequently the possible outcomes of a legal decision. ${ }^{586}$ This aspect of reasoning in law leads towards the ideal of certainty that is necessary for the Rule of Law to operate.

585 Neil MacCormick, Rhetoric and The Rule of Law: A Theory of Legal Reasoning (Oxford 2005) 254-55.

586 (' $[. .$.$] the legal answer 'always has to be capable of being framed in terms of law, through interpretation$ of statues or of precedents, or of legal principles developed through reflection on law as practically coherent normative order'. In this vein, a primary requirement of legal reasoning is to show that the ruling 'does not contradict validly established rules of law'. A second requirement is to show that the decision is supported by established legal principles. [...]') Flavia Carbonell, 'Reasoning by Consequences: Applying Different Argumentation Structures to the Analysis of Consequentialist Reasoning in Judicial Decisions' in Christian Dahlman and Eveline Feteris (eds), Legal Argumentation Theory: Cross-Disciplinary Perspectives, vol 102 (Springer 2013) 6. 
In respect of the second aspect, which follows directly from the first, legal decisions are utterances of what the law is at a given moment, and as such they also function normatively in regulating the conduct of the population subsumed to it. The reasoning behind a decision, whether the precedent doctrine operates within the legal system or not, is informative of the state of the law and is used as a yardstick for legal/illegal behavior. Lawyers will advise their clients about the legality of a given path of behavior based both on statute and on the decisions of the relevant courts in the jurisdictions in which the client operates: in case a dispute arises out of a similar fact pattern as it had been decided before, the previous judgment will be used as an argument of the current state of the law, even if it is not strictly binding under the rules of that particular legal system. ${ }^{587}$

As established in the previous paragraphs, the existence of reasoned decisions is an important aspect of the operation of a legal system which purports to regulate effectively the conduct of those subject to it. Even though reasoned decisions are important, something more is needed for them to comply with their function of being the substrate of legal arguments and future legal decisions. Any person who wants to access a judicial decision should be able to do so without incurring any major costs (and preferably, be able to do so for for free), therefore creating an environment of transparency in the operation of the legal system.

Transparency in legal decision-making bodies brings important advantage to their operation and the efficiency of the legal system as a whole. An interesting study about transparency in the civil justice system in the United States was published in 2012, underlining its importance and the benefits accruing from it. ${ }^{588}$ Essentially, the study concluded that transparency would improve the functioning of the market in claim settlements, decrease fraud, increase confidence and decrease transaction costs. ${ }^{589}$ The conclusions are intuitive; if information is concentrated in a single database that is easily accessible, the general costs that the system creates will be lower since duplicative efforts

\footnotetext{
${ }^{587}$ As in Brazil, that does not have a doctrine of stare decisis, even though many commentators argue that judicial decisions have legal value for future cases. See Fredie Didier Junior, Curso de Direito Processual Civil - Volume 2 (5 edn, Editora JusPODIVM 2010) 386-87.

588 Joseph W. Doherty, Robert T. Reville and Laura Zakaras (eds), Confidentiality, Transparency, and the U.S. Civil Justice System (Oxford University Press 2012).

589 Ibid xxv.
} 
to produce the same information will be avoided. ${ }^{590}$ To a certain extent, the argument is the same as with disclosure duties for securities regulation.

Also, at a more fundamental level, justice should be accessible to everyone; differentiating the access to crucial information about the law through the financial capabilities of the parties - by allowing access only through paid means, for example would create an unnecessary and unjust bias to the party with greater financial means. ${ }^{591}$

Whether it is a matter for the efficiency or the fairness of the system, reasoned decisions and easy access to it should be pursued as objectives in any proposal for a dispute resolution system.

\section{Economic Aspects of the Institutional Framework}

There are two sides to consider regarding the economic aspects of a dispute resolution system: A) the costs of maintaining a dispute resolution system; and B) the costs of accessing a dispute resolution system.

\section{A. Costs of Maintaining a Dispute Resolution System}

Dispute resolution systems need to be funded. They will require a physical location and employees to carry out the activities they perform. The total costs will depend on the size of the institution and the array of services offered; for example, those institutions that only coordinate dispute resolution but do not maintain the decision-makers in their payroll will have a lower percentage of fixed costs when compared to court systems,

\footnotetext{
590 Think for example on the case of a legal system that implemented a central database accessible through the internet - before the implementation each party would have to ask for the production of a copy of the judgment on paper, what would have to be mailed to the parties. After the implementation of the system the parties will only print the judgment if they feel the need to read it on paper, as it could be accessible through the internet at any time.

${ }^{591}$ See Lynn M. LoPucki, 'The Future of Court System Transparency' in Joseph W. Doherty, Robert T. Reville and Laura Zakaras (eds), Confidentiality, Transparency, and the US Civil Justice System (Oxford University Press 2012) 170-71. It is true that in any event the party with less money will be disadvantaged, but the difference is that at least theoretically, the lawyer of this party will have the same possibility of preparing a strong case than the lawyer of the richer party. In case money is charged to access court decisions, the access to law itself is impaired.
} 
which will necessarily need judges and support staff that will be paid on a regular basis, regardless of the amount of cases being filed.

Such considerations are important because the success of a dispute resolution system will depend on its costs and how the costs will be borne. A completely private design will create a dispute resolution body that is a business, which will lead to incentives in pleasing the users of the system. On the other hand, a system that is public will have a higher degree of independence but will also require financial commitment from states to be able to properly perform its activities.

The choice then is how to allocate the costs between the users of the system and the political community supporting it. In most cases where the jurisdictional legal basis is direct, the system will be funded both by the political community through taxation and the requirement that the users pay a fee to access the system. On the other hand, when the legal basis for jurisdiction is indirect, the model of the dispute resolution system will be more of a business, receiving money from the users of the system and sometimes from the business community that has an interest in supporting it.

\section{B. Costs of Engaging in a Dispute Resolution Procedure}

Every decision to engage in a legal dispute has to take into account the costs that the dispute will entail compared to the likelihood of the claim's success. The best-case scenario for someone considering engaging in litigation is a high value claim with a high likelihood of success. Each legal system differs substantially regarding the costs of litigation, which can amount to millions of dollars for each party. ${ }^{592}$ Even though securities disputes costs may amount to millions, individual investors rarely have a high amount at stake in their dispute and depending on the costs needed access to justice, may be precluded exclusively based on them.

Here there is an inherent tension between costs and access to justice. The higher the costs, the harder it is to obtain access, which then requires alternative methods of

\footnotetext{
${ }^{592}$ For a comparative view on the costs of civil litigation, see Hodges, Vogenauer and Tulibacka (n 581).
} 
access and legal support to those parties that do not have it. Costs can be divided into a) costs of access and b) costs of evidence and representation.

\section{a. Costs of Access}

Every court system or arbitral institution requires the payment of a fee for access to the dispute resolution system. The fee can be applied either at the beginning of the litigation or at various steps along the way. ${ }^{593}$ In any event, the minimum cost that should be considered for matters of 'dispute resolution' should be the amount dispensed from the beginning of the lawsuit until the first instance decision, which is the first stage at which the dispute has been effectively solved by a third-party to the dispute. ${ }^{594}$ Within this idea of cost of access, the remuneration of arbitrators has also to be taken into account since in many systems it has to be paid up front. These costs can vary immensely.

To illustrate the difference, the table below shows a comparison for a $\$ 100.000$ value dispute among different dispute resolution systems:

\begin{tabular}{|l|l|l|l|l|l|}
\hline & US595 & Brazil $^{596}$ & Spain $^{597}$ & Finra598 & ICC599 \\
\hline Filing Fees & $\$ 350$ & $\$ 1.000$ & $\$ 695,15$ & $\$ 1.425$ & $\$ 3.000$ \\
\hline $\begin{array}{l}\text { Arbitrator } \\
\text { Fees }\end{array}$ (100 & - & - & - & $\$ 450$ & $\$ 10.060$ \\
\hline
\end{tabular}

593 Ibid 14.

594 The dispute could be solved through settlement after the beginning of a lawsuit, but this would not entail the full use of the dispute resolution system.

595 Southern District of New York.

596 Sao Paulo Tribunal.

597 Jean Albert, Study on the Transparency of Costs of Civil Judicial Proceedings in the European Union - Final Report - Annex 48 - Spain (2007) 22.

598 Finra Customer Code, ss 12900 and 12902.

599 International Chamber of Commerce ICC, 'ICC Cost Calculator' <http://www.iccwbo.org/Products-andServices/Arbitration-and-ADR/Arbitration/Cost-and-payment/Cost-calculator/> accessed 8 July 2014.

600 The arbitrator fees are based on the median value of those displayed in the documents regulating each system. 


\begin{tabular}{|l|l|l|l|l|l|}
\hline Total & $\$ 350$ & $\$ 1.000$ & $\$ 695,15$ & $\$ 1.875$ & $\$ 13.060$ \\
\hline
\end{tabular}

In this comparison, it becomes clear that stepping through the door of arbitration can be more expensive than proceeding to litigation. Even at Finra, the securities arbitration institution in the United States that is prepared to handle customer (investor) arbitrations, the cost of simply engaging in arbitration amounts almost to $2 \%$ of the total value of the dispute, where in courts this would not exceed 1\%.601 At the ICC, one of the most prestigious arbitration institutions in the world, the cost of engaging in a $\$ 100.000$ dispute is simply prohibitive, amounting to more than $13 \%$ of the claim just for the filing of the dispute and remuneration of the arbitrators.

\section{b. Costs of Evidence and Representation}

Evidence production and review are other important aspects of the cost structure of dispute resolution in securities disputes. Here the main culprits are common law style discovery and expert witnesses.

Discovery is an institution of civil procedure that is alien to civil law lawyers. It allows one party to demand the production of information by the other party on an extensive basis, encompassing more or less anything that is relevant to the claim or defense; ${ }^{602}$ this imposes extreme burdens both on the party who has to organize the documents and also on the party requesting the documents who will be required to review them.

To the extent that any given type of dispute has a wide factual background that can be accessed through discovery, institutional designs that allow for this procedural possibility will be much more costly for litigants than the systems that have capped these methods. Document collection, review and production are tasks that are often done by

\footnotetext{
${ }^{601}$ In the jurisdictions researched, the most expensive one would be Brazil.

${ }^{602}$ See Federal Rules of Civil Procedure, s 26(b).
} 
the party's lawyers, mixing to some degree this type of costs with the costs of representation.

Lawyer's fees depend largely on the jurisdiction and the profile of the law firm providing the service. Smaller law firms may charge by the lawsuit being pursued, while larger law firms usually have a hourly-rate fee for the service provided, which averages, at least in the United States, at $\$ 250,00$ an hour. ${ }^{603}$

At these rates, any type of dispute that would require even a not-so-extensive discovery process would, as a matter of fact, make it impossible for the average investor to pursue a lawsuit, unless the investor was joined by similarly situated investors to proceed with a mass claims proceeding. When low values are at stake, the dispute resolution system design has to allow for low costs of evidence and representation, otherwise low value claims will be banned from legal protection.

\section{Implications of the Institutional Framework for a Dispute Resolution System}

As the objective of this thesis is to propose a dispute resolution system for transnational securities transactions that is more reliable than the current alternatives in existence, the establishment of the parameters to analyze their institutional framework becomes the first step in achieving this aim.

Legal systems exist to manage expectations and to coordinate social interactions. In economic transactions, they are important because they allow the parties to plan for the future, relying on the legal system to guarantee that promises will be kept and assets will be protected. With regards to this aspect, private enforcement is the centerpiece of the efficiency of the system.

The reliability of the legal system is dependent on the operation of the Rule of Law principle through institutions designed to operate as objectively as possible. Since the

\footnotetext{
603 Nicholas M. Pace and Laura Zakaras, Where the Money Goes: Understanding Litigation Expenditures for
} Producing Electronic Discovery (Rand Institute for Civil Justice 2012). 
dispute resolution forum is where the law will be applied in the specific case, its design has to be made so as to avoid subjective considerations as much as possible.

The first part of this chapter showed that two of the most essential component parts for this to be accomplished are a) the balance between the independence and accountability of the decision-makers and b) the transparency of their decisions. These considerations, while not definitely tied to the type of jurisdiction granting mechanism, are to some extent defined by it.

By having a well-designed balance between the independence and the accountability of the decision-maker, the dispute resolution system guarantees that it will operate according to the Rule of Law, bringing to it all the positive aspects related to economic planning and production.

Regarding transparency, it is not so important if a single dispute is considered; an arbitration, the main focus of which is simply to solve definitely a dispute, will most likely be tailored to the needs of the parties engaging in it. For example, confidentiality may be important because the parties do not want other parties to know about their dealings. The problem is that a dispute resolution system, with a specific focus in solving single disputes, may create problems for the legal system as a whole. Decisions that are not made public impair the development of law, as the market will not be able to be guided by these decisions and develop expectations around them; this brings back one of the most important issues that law has been created to solve, namely, certainty in social relations.

Therefore, if a dispute resolution system purports to be comprehensive in a given field of disputes, be it vested with direct or indirect jurisdiction, it has to be designed in a manner whereby decision-makers have strong incentives to consider only legal arguments and where the transparency of decisions is allowed so the legal system can evolve.

The second dimension of this chapter is related to the economic considerations of a dispute resolution system. On the one hand, the system has to be funded; the two pure models are state-funded systems and business-funded systems. In practice, this has some relationship to the type of jurisdiction-granting mechanism upon which the dispute resolution system is based; systems with direct jurisdiction are usually financed by some kind of taxation, either over the population in general or over specific users of the system, 
while systems based on consent jurisdiction mechanisms are funded by the users of the system or by businesses that feel it appropriate to have a parallel dispute resolution system in place.

Finally, the second economic aspect, the costs of engaging in litigation, is essential to the analysis made in the next chapters, as it is linked to the incentives for the exercise of private enforcement. For claims to be litigated, they have to bring an expected benefit to the claimant. If the value of the claim is lower than the cost of engaging in litigation, the claim will not be litigated. Even if the system allows claims to be litigated for free, as in some small claims systems, the claim value might be so low that it is not worthwhile for the claimant to pursue it. Aggregate litigation mechanisms then becomes an interesting option, allowing for the collection of claims to increase the possible economic output of the dispute, creating an opportunity for other parties to get involved and providing a wider avenue for access to justice.604

The Rule of Law and access to justice, therefore, is paramount to the efficiency of private enforcement of securities laws, both in respect of the compensation and the deterrence aspects of securities regulation. The next chapter surveys different dispute resolution systems that could be used as models to create a system working within the principles of the Rule of Law and providing wider access for securities disputes, enabling self-reliance on the private enforcement of securities laws; thereafter, Chapter VIII analyses the incentives for private enforcement in aggregate litigation and the possible pitfalls that this type of procedural mechanism may create.

${ }^{604}$ See Christopher Hodges, The Reform of Class and Representative Actions in European Legal Systems (Hart Publishing 2008) 187-91 Samuel Issacharoff, 'Governance and Legitimacy in the Law of Class Actions' [1999] 1999 Supreme Court Review 337. 


\section{Chapter VII - Alternative Models of Dispute Resolution Systems}

The previous chapter has established core institutional aspects of a dispute resolution system and has provided some insight on how such a system could comply with the Rule of Law principle and be an adequate mechanism for private enforcement. This section will use this previous discussion as a basis to analyze some of the important dispute resolution systems that can be used to solve financial transactions in the world (and other systems not directly related to financial disputes but which could nevertheless be used to solve them).

The objective of this chapter is to outline how different dispute resolution mechanisms that could be potentially used for securities disputes are structured. Due to the transnational character of the problem proposed by this thesis, this chapter is divided into 1) national models and 2) transnational models.

\section{National Models}

National models of dispute resolution systems are those based within the bounds of a state. Even though they can deal with disputes that are transnational, their institutional structure is nation-based.

\section{A. Small Claims Court Model}

Small claims courts are dispute resolution systems within the state structure that are an alternative to the normal procedure of the court system. They are designed to provide easy access to the justice system by allowing a person to sue without a lawyer and by having low access costs. The decision-maker is either a judge or a person overseen by a judge; the authority of the decision is the same as the one given through normal proceedings. Funding for the small claims courts comes from the state. Small claim courts have, by definition, a limited jurisdictional scope based on the claim's amount, while at 
the same time they may restrict those who have standing to sue. ${ }^{605}$ The small claim courts model is completely public.

The Brazilian system is an interesting one. Small claim courts in Brazil have existed since 1984.606 Their introduction into the Brazilian legal system had the initial goal of opening access to justice to a part of the population that otherwise could not use the judiciary to seek legal relief. ${ }^{607}$ Subsequently, the justification for the system has also been broadened to encompass the overburdened courts that existed (and continue to exist) in Brazil.608

Bureaucracy was previously a much more ugly monster than it is today in Brazil. In 1979, the Brazilian government started the National Program of Deburocratization to diminish the bureaucratic requirements that were widespread in the Brazilian government. ${ }^{609}$ In the same period, the Rio Grande do Sul Judiciary was testing a simpler method of dispute resolution that would avoid the high costs and the delay that were common in Brazilian courts. ${ }^{610}$ This setting, and the inspiration that a Secretary from the Deburocratization Ministry had from the small claims court in New York, ${ }^{611}$ formed the background against which the Brazilian small claims courts were created.

In 1995, the legal and institutional structures of the small claims courts were broadened, both regarding the amount of the disputes that were accepted within its jurisdiction as well as the legal problems at stake. Law 9.099/95, currently in force, was the legal instrument that provided for these changes.

\footnotetext{
${ }^{605}$ For example, in the NY Small Claims Court System, businesses are not allowed to sue. See Judith S. Kaye and Jonathan Lippman, A Guide to Small Claims in the NYS City, Town and Village Courts (New York State Unified Court System New York State Unified Court System).

606 Law 7.244/1984.

${ }^{607}$ Ana Carolina da Matta Chasin, 'Uma Simples Formalidade: estudo sobre a experiência dos Juizados Especiais Cíveis em São Paulo' (LLM, USP 2007).

608 Ibid .

${ }^{609}$ Ibid 42-43.

${ }^{610}$ See ibid 51-54.

611 Ibid 50.
} 
The procedure in the small claims courts is simpler than in normal courts. For disputes up to $\mathrm{R} \$ 14.480$, a lawyer is not necessary to assist in the lawsuit. ${ }^{612}$ The procedure is basically divided into two hearings: during the first, a conciliator will try to lead the parties to an agreement; ${ }^{613}$ if an agreement is not reached, a second hearing will be organized so evidence can be presented and the judge can be instructed. ${ }^{614}$ Appeals are possible and are made to a collegiate of three career judges. ${ }^{615}$

There are three main figures in the dispute resolution method of the small claim courts in Brazil: the career judge, the layman judge and the conciliator. The career judge is the only one who is a proper judge, approved by public exam and invested with judicial powers. Any actions that are taken by the layman judge or the conciliator are under the supervision of the career judge. The difference is a functional one; the layman judge will preside over the instruction and judgment hearings and proffer sentences subject to the career judge's approval, 616 while the conciliator can only preside over conciliation hearings. ${ }^{617}$

This structure allows for a smaller cost in dispensing justice and solving disputes. For example, while a judge earns around $\mathrm{R} \$ 20.000,618$ a layman judge can be remunerated up to $\mathrm{R} \$ 3.000$ a month, ${ }^{619}$ depending on the amount of work that has been done. The difference is substantial.

Criticisms have been advanced that the quality of justice would be different, depending on the claim chosen; those who could afford a full proceeding would have more

\footnotetext{
612 The parameter is disputes up to 20 minimum salaries (Art. 9 Lei 9.099/95). Also, small claims courts can entertain disputes up to 40 minimum salaries (Art. 3, I, Lei 9.099/95).

613 Law 9.099/95, art 22.

${ }^{614}$ Law 9.099/95, arts 27-29.

615 Law 9.099/95, art $41 \S 1$.

${ }^{616}$ Law 9.099/95, art 40.

617 Law 9.099/95, art 22.

${ }^{618}$ For example, in Mato Grosso do Sul a judge at the beginning of his career receives R $\$ 20.517,59$. See 'Estrutura Remuneratória - Cargos Efetivos' <http://www.tjms.jus.br/transparencia/resolucao102/anexo3_estrutura_remuneratoria.php> accessed 8 July 2014.

${ }^{619}$ In the State of Mato Grosso do Sul, this would mean deciding around 42 cases, while for each case, the layman judge would receive R\$71,00. Resolution TJMS 564 (2010), art 2.
} 
'justice' than those subsumed to the small claims system. ${ }^{620}$ Even though there is some appeal to such an argument, since those who are paid more tend to be better trained than those who are paid less and more evidence results in more facts being provided to the decision-maker, this is also highly dependent on the institutional structure of the small claims courts. ${ }^{621}$

A compromise must also be reached between costs, quality of justice, whatever this means, and access to justice. A slightly poorer justice is better than no justice at all, a situation which might arise because the costs are too high for disputes to be entertained or because the proceedings for the 'better quality' justice become too long due to the demand on the court system, such that it becomes virtually impossible for a judicial decision to be of any use.

\section{B. The Financial Ombudsman Service Model}

The Financial Ombudsman Service Model is a different scheme in comparison to the small claims court model. Its funding is more specific, the decision-makers are not judges and the binding effects of the decision are different than those of a judicial decision.

One of the most successful financial ombudsman services is the UK Financial Ombudsman Service. It is a public body that was created by the UK Parliament in $2000^{622}$ and run by a 'company limited by guarantee and not having a share capital', 623 the Financial Ombudsman Service Limited, the 'scheme operator' under the Financial Markets Act 2000.624

The idea behind the scheme was to resolve disputes 'quickly and with minimum formality by an independent person' 625 regarding services provided within the financial industry in the UK; it appears that this service has been successful: the 2012/2013 annual

\footnotetext{
${ }^{620}$ Chasin 54-58 (n 607). in the two courts that she studied. See ibid 87-163.

622 Financial Services and Markets Act 2000, Part XVI and Schedule 17.

${ }^{623}$ Articles of Association of Financial Ombudsman Service Limited.

${ }^{624}$ Financial Markets Act 2000, s 225.

${ }^{625}$ Financial Services and Markets Act 2000, s 225(1).
}

${ }^{621}$ Chasin has shown in her work that despite being under the same 'small claims court' legislation and within the same city, there were significant differences in the operation of the 'small claims court' system 
review showed that there were 2,161,439 calls to their helpline and 508,881 new cases. Their track record was also good; $81 \%$ of all cases were solved in less than 12 months. ${ }^{626}$

These are substantial numbers, which show that the service has attracted a considerable number of users. As substantial as the amount of cases with which the Financial Ombudsman Service is dealing, the budget for its operation, which was of 191.1 million pounds for 2012/2013, is also substantial. ${ }^{627}$ Its financing structure is interesting. It depends on a levy imposed on financial firms as a cost of doing business and, mainly, on the income that is also received from these firms according to the cases that are brought against them. ${ }^{628}$ Even though the levy is a form of taxation and the burden of sustaining the system falls on financial firms, it is a fair structure as it provides access to justice to financial customers and to some extent, the financing also comes from the consumers themselves, since they will be paying for the services they obtain from financial firms, who have to take into account their costs of doing business while deciding how much they will charge their customers.

The scheme derives its authority from the Financial Services Markets Act 2000,629 the Consumer Credit Act $2006^{630}$ and from regulations enacted by the Financial Conduct Authority, 631 the UK body in charge of regulating 'conduct in retail, as well as wholesale, financial markets and the infrastructure that supports those markets'.632 More limited in

${ }^{626}$ See 'Annual Review 2012/2013' (Financial Ombudsman Service, 1 April 2012 to 31 March 2013) <http://www.financial-ombudsman.org.uk/publications/ar13/dealt.html> accessed 8 July 2014.

627 There was an expected deficit of 6.4 million pounds for last year, but this was due to a surge in PPI cases and the necessity to hire and train new staff ibid .

${ }^{628}$ The levy ranges from 100 pounds to 300,000 pounds, depending on the size of the firm, and it covered 9.3\% of the budget in 2012/2013 'Our Plans and Budget for 2012/2013 - Finalised and Approved' (Financial Ombudsman Service, 27 March 2012) <http://www.financialombudsman.org.uk/news/updates/planandbudget-2012-13-approved.html> accessed 8 July 2014. Case fees are currently at 550 pounds per case, but are charged only on the cases after the $25^{\text {th }}$ case that is brought against the company. There is also a surcharge of 350 pounds for cases involving payment protection insurance (see 'Our Plans and Budget for 2013/2014 - Finalised and Approved' (Financial Ombudsman Service, $20 \quad$ March 2013) <http://www.financialombudsman.org.uk/news/updates/plan_and_budget_13-14.html> accessed 8 July 2014.

${ }^{629}$ Part XVI and Schedule 17.

${ }^{630}$ Section 59.

${ }^{631}$ FCA Handbook.

${ }^{632}$ See 'Regulatory Reform - Background' (Financial Services Authority) <http://www.fsa.gov.uk/about/what/reg_reform/background> accessed 8 July 2014. 
scope than courts, the disputes entertained within this system are only those related to regulated activities from investment firms in the UK or collective portfolio management services provided by an EEA UCITS management company or by an EEA AIFM; 633 the jurisdiction is also only available to consumers or otherwise low asset value institutions, ${ }^{634}$ with maximum awards of $£ 150.000 .635$

The dispute resolution system is mainly informal and is done first through a conciliation/mediation procedure that is performed by the 'adjudicators', who try to resolve the matter and issue an opinion on how the case should be solved. This opinion is not binding and if the parties do not reach an agreement they can make a request that the case be decided by the ombudsman. After the ombudsman decision is issued, the consumer can either accept it or not. If the decision is accepted, it is binding on both parties, otherwise it is not binding and the consumer can still seek redress through the court system. ${ }^{636}$

The Ombudsman Service is under the supervision of a Board, with its members being appointed by the FCA. ${ }^{637}$ Board members are appointed to serve in the public interest, and not as the representatives of any sector of the financial services industry. ${ }^{638}$ The Board is then in charge of appointing and maintaining a panel of ombudsmen. ${ }^{639}$

Finally, regarding the decision made, the UK Financial Ombudsmen Service is becoming more transparent. It has already started publishing the decisions taken, as required by the amendments to the Financial Services and Markets Act 2000 introduced by the Financial Services Act 2012. The publicity of the decisions is a positive change since

${ }^{633}$ FCA Handbook, DISP 2.3.1 and 2.6.1.

${ }^{634}$ FCA Handbook, DISP 2.7.6.

635 FCA Handbook, DISP 3.7.4.

${ }^{636}$ See Financial Ombudsman Service, The Ombudsman and Larger Businesses (2012) 7-9; FCA Handbook DISP, 3.6.6(4) and 4(A).

${ }^{637}$ The chairman also needs the approval of the HM Treasury. Financial Services and Markets Act 2000, Schedule 17, 3(2).

638 'Information for Businesses Covered by the Ombudsman Service' (Financial Ombudsman Service) <http://www.financial-ombudsman.org.uk/faq/businesses/answers/rules_a8.html> accessed 8 July 2014. ${ }^{639}$ See Articles of Association of Financial Ombudsman Service Limited, s 15. 
it makes the system more transparent and gives businesses more resources to understand better what is expected of them, improving legal certainty.

For the purposes of this work, this is a very interesting scheme. It finances roughly $80 \%$ of its operation through case-related revenue, it is consumer friendly, it solves disputes in a considerable short amount of time and it renders binding decisions. Such characteristics could be interesting for a transnational system for securities disputes, especially when having in mind the small and medium investor.

\section{Self-Regulation Model}

Another option is to have the dispute resolution system embedded in the market control mechanisms that are overseen by the organized securities markets, under a selfregulation model.

In Brazil, this is the option that has been chosen for disputes up to $\mathrm{R} \$ 70.000640$ that involve financial intermediaries and investors when the dispute concerns the intermediation of securities transactions or custody services. ${ }^{641}$

The mechanism is run by BMF\&Bovespa through its regulatory body, the BM\&FBovespa Supervisão de Mercados (BSM), which has rules and regulations that govern the procedure for the dispute resolution mechanism. ${ }^{642}$

The decisions are taken either by the Supervision Council ${ }^{643}$ or the Director of SelfRegulation, who are appointed by the General Assembly of the BSM. ${ }^{644}$ The arrangement does not guarantee much independence since the decision makers are under the complete control of BM\&FBovespa, the Brazilian securities market.

\footnotetext{
640 Instruction CVM 461, art 80 para 1.

641 Instruction CVM 461, art 77.

642 See Regulation of the Loss Recovery Mechanism.

${ }^{643}$ A group of three Counselors will decide on a given dispute in the Ordinary Procedure.

${ }^{644}$ BM\&FBOVESPA Supervisão de Mercados, Estatuto Social da BM\&FBOVESPA Supervisão de Mercados $B S M$ (2011) arts 16, I and II. This means that legally BSM is totally controlled by the BM\&FBovespa, since BSM associated parties are BM\&FBovespa and Banco BM\&F de Serviços de Liquidação e Custódia S.A, which is controlled by BM\&FBovespa (see 'Quem Somos' (Banco BM\&FBOVESPA) <http://www.bmfbovespa.com.br/bancobmfbovespa/institucional.asp> accessed 8 July 2014).
} 
Even though decisions are made by persons who are members of this private body, due to the public aspect of a securities market, the decision can be appealed to the CVM, the Brazilian public agency in charge of regulating the securities market, ${ }^{645}$ which then renders an administrative decision. ${ }^{646}$ Since administrative decisions in Brazil do not preclude the use of the judiciary, both parties can still start a lawsuit over the same subject matter of the dispute if they are not satisfied with the decision proffered.

Regarding the reasoning of decisions and transparency, the mechanism can be used as a good example because both the BSM and the CVM decisions are published on the website and legal reasoning is provided, allowing a body of precedent to develop.

Access is not as easy as it is for other mechanisms; it is highly bureaucratized, requiring the recognition of the claimant's signature by a public notary. The good part about it is that it is free and they provide a form and a manual to make it easier for a complaint to be made.

\section{Arbitration}

Continuing on from the most to the least public dispute resolution scheme, arbitration may be divided into those schemes that have some degree of public influence, the State Supervised Model, to the more general arbitration schemes that operate only through the enabling legislation of a state.

\section{a. State Supervised Model}

Arbitration is supposedly a purely private mechanism of dispute resolution. Even though this is how arbitration initially developed, there are schemes that are based on an arbitration framework but in which there is a strong public presence, to the extent that its 'voluntary' character is stripped and it becomes the only de facto method for solving disputes.

This is the case of FINRA, the dispute resolution scheme in the United States for disputes between consumers and financial intermediaries. '(FINRA) is the largest

\footnotetext{
645 Instruction CVM 461, art 81, para 1, and Regulation of the Loss Recovery Mechanism, art 26, III.

${ }^{646}$ Regulation of the Loss Recovery Mechanism, art. 29.
} 
independent regulator of securities firms doing business with the public in the United States'.647 FINRA arose out of 'the consolidation of NASD and the member regulation, enforcement and arbitration operations of the New York Stock Exchange'.648 It is an industry self-regulatory organization, falling under the supervision of the SEC.

The power exercised by FINRA derives from its registration with the SEC under Section 15A of the Securities and Exchange Act 1934. Since any broker-dealer must be registered with a Section 15A-registered securities association, FINRA being the only one at the moment, it exercises a public power since registration and compliance with its rules is mandatory for brokers-dealers to be legally able to exercise their activity. ${ }^{649}$

FINRA maintains a dispute resolution scheme based on arbitration, which is imposed on its members either by a contractual commitment with investors or by FINRA Rule 12200. 650 The option for the investor is only theoretical as most financial intermediaries include an arbitration clause in their contract, imposing the use of the FINRA forum for dispute resolution. ${ }^{651}$ On the other hand, and characterizing the public aspect of the FINRA scheme, the broker-dealers cannot escape this dispute resolution method since they must be registered with FINRA to exercise their functions.

Arbitrators for a particular dispute are selected from a list that is randomly generated from FINRA's roster. Parties then will be able to strike arbitrators from the list and rank their choices. Since January 31, 2011, on a three-arbitrator panel, customers

\footnotetext{
647 'About Finra' (Financial Industry Regulatory Authority) <http://www.finra.org/AboutFINRA/> accessed 8 July 2014.

${ }^{648}$ FINRA, NASD and NYSE Member Regulation Combine to Form the Financial Industry Regulatory Authority - FINRA (2007).

${ }^{649}$ Securities and Exchange Act 1934, s 15 (b)(1).

650 'Parties must arbitrate a dispute under the Code if:

Arbitration under the Code is either:

Required by a written agreement, or

Requested by the customer; (...)'

651 See NASAA, 'Mandatory Binding Arbitration: Is it Fair and Voluntary?' 15 September 2009 <http://www.nasaa.org/807/mandatory-binding-arbitration-is-it-fair-and-voluntary/> accessed 8 July 2014.
} 
have a choice to request the appointment of a panel composed by public arbitrators only; previously, one arbitrator connected to the securities industry was always present. 652

FINRA arbitrators do need to have some qualifications, such as five years of professional experience and two years of college-level credits, in addition to completing a training program. ${ }^{653}$ These do not seem to be extremely high requirements and anyone who fulfills them is able to become a FINRA arbitrator. Therefore, there are no strong checks regarding arbitrator independence; moreover, reputation does not seem to be a proper mechanism to guarantee it in this context. 654

Another negative point of the FINRA arbitration process is that decisions are usually not reasoned. As mentioned above, the lack of reasoning is a problem to the operation of the Rule of Law, especially in an institutional setting where almost all similar disputes are solved through this forum.

Fees are paid along the way, depending on the acts required. For example, a party has to pay a fee to file the claim, but if the other party wants to counterclaim, they also have to pay a fee. If a hearing is requested, additional fees are due.

A positive point to this approach however is that most decisions against financial intermediaries are voluntarily complied with. As FINRA has regulatory power over its members, it can suspend or revoke their license if they do not comply with the arbitrators' decision within 30 days, therefore being an extremely efficient dispute resolution mechanism..$^{655}$

652 See 'Optional All Public Panel Rules' $($ FINRA) <http://www.finra.org/ArbitrationAndMediation/Arbitration/Rules/NoticestoArbitratorsParties/Notice stoParties/P123997> accessed 8 July 2014.

653 See $\quad$ FINRA, 'FINRA's Arbitrators' <http://www.finra.org/ArbitrationAndMediation/Arbitrators/BecomeanArbitrator/FINRAArbitrators/in dex.htm> accessed 8 July 2014.

${ }^{654}$ In a manner that differs from commercial arbitration, which involves high stakes disputes and has a small community of arbitrators that are chosen based on their reputation due to the repeat player nature of the law firms involved in them, securities arbitration involves smaller claims that are brought mainly by consumers who are not likely to be coming back and learning about the institutional characteristics of the forum and the specific arbitrators.

655 See Jill I. Gross, 'The End of Mandatory Securities Arbitration?' (2010) 30 Pace Law Review 1174, 1189 FINRA Rules 12904. 
The interesting characteristic of this scheme is that it is privately managed under the supervision of a public authority, which will be in charge of guaranteeing that the scheme remains truthful to its goals. ${ }^{656}$ There are a few shortcomings, namely, the lack of proper mechanisms to guarantee arbitrator independence and the lack of reasoned decisions, which are important aspects of a legal system operating under the Rule of Law.

\section{b. Private Arbitration Model}

The Private Arbitration Model 657 is the general arbitration model. Even though this sub-section falls within the 'national' division of this section, the private arbitration model functions both for national as well as transnational disputes; the decision to place it here was because their institutional structure is tied to a state, which is to say that it differs from the international arbitration model discussed in the next section, which is tied to more than one state. ${ }^{658}$ It is characterized by complete freedom of the parties to engage in arbitration, whether through a contractual clause agreed upon before the dispute arises or by an agreement to arbitrate afterwards.

The only role of the state in a private arbitration model is to guarantee that agreements to arbitrate will be legally binding - which means that once someone agrees to arbitrate, the dispute has to be submitted to arbitration and the decision of the arbitrator will be executable through the courts of law of that state. The whole scheme is characterized by the exclusive presence of parties acting in their private capacity.

An arbitral institution usually manages a private arbitration procedure. This institution is in charge of guaranteeing that the procedure develops seamlessly and that the decisions made by the arbitrators will be legally enforceable. Remuneration of the arbitral institution and of the arbitrators is paid by the parties to the dispute; the manner in which remuneration accrues varies depending on the arbitral institution.

\footnotetext{
${ }^{656}$ For example, easy access to dispute resolution.

657 In the arbitration scholarship, this is the commercial arbitration model, as investment arbitration always involves the state as one of the parties of the dispute and is based on treaties.

${ }^{658}$ An arbitral institution has to be constituted according to the laws of a state, unless created by an international treaty.
} 
The guarantee of arbitrator independence is based mostly on reputational aspects. There are a few mechanisms within the legal framework for arbitration that can cure a lack of independence, but these are ex post mechanisms of control, such as the nonenforcement based on arbitrator's partiality.

The specific dispute resolution schemes are tied to the arbitral institutions that manage the arbitration. Arbitration is usually used in the following manner: parties choose an arbitral institution to manage the dispute and then the selection of the arbitrators and the constitution of the arbitral panel will be done according to the rules of that arbitral institution. ${ }^{659}$

There are various famous arbitral institutions, such as the International Court of Arbitration of the International Chamber of Commerce, the American Arbitration Association and the London Court of International Arbitration. Two that are worth a closer look are the Câmara de Arbitragem do Mercado and P.R.I.M.E. Finance, since the propose to deal with disputes tied to financial transactions.

The Câmara de Arbitragem do Mercado (CAM) is an arbitral institution based in Brazil. It was created by BOVESPA (now BM\&FBOVESPA), the Brazilian stock exchange, in 2001. CAM was designed to manage arbitral procedures based on conflicts originating from companies listed on BM\&FBOVESPA. 660

The use of CAM to arbitrate corporate disputes is mandatory for those companies that are listed on the higher corporate governance levels of BM\&FBOVESPA: Novo Mercado, Nível 2 and BOVESPA Mais. ${ }^{661}$

The arbitrator roster is a limited one, with only 40 people. ${ }^{662}$ These are highly regarded professionals of the Brazilian bar, containing names such as Calixto Salomão

${ }^{659}$ For example, the ICC Rules of Arbitration.

660 This information is on their website. See BM\&FBOVESPA, 'Câmara de Arbitragem do Mercado' (BM\&FBOVESPA) <http://www.camaradomercado.com.br/> accessed 8 July 2014.

661 See BM\&FBOVESPA, 'O que são Segmentos de Listagem' (BM\&FBOVESPA) $<$ http://www.bmfbovespa.com.br/pt-br/servicos/solucoes-para-empresas/segmentos-de-listagem/oque-sao-segmentos-de-listagem.aspx?Idioma=pt-br> accessed 8 July 2014.

662 Other arbitrators can be chosen but have to be confirmed by the President and one of the Vice-Presidents of CAM. Regulation of the Câmara de Arbitragem do Mercado, s 3.7. 
Filho, Ary Oswaldo Mattos Filho and Luis Olavo Baptista, amongst others. Independence therefore is based on reputation, as there are no other mechanisms of control besides the request to change arbitrators in case a suspicion of impartiality arises. ${ }^{663}$

It is interesting that CAM uses the word transparency as something important for listed companies since the arbitral procedure that they offer is confidential according to their arbitration rules, ${ }^{664}$ giving no publicity for the decisions and actually diminishing transparency when compared to the Brazilian judicial procedure. ${ }^{665}$ It is true that there is no obligation for listed companies to solve their disputes through CAM arbitration, but those who wish to comply with higher corporate governance standards tend to be the bigger companies, a situation that necessarily leads to more complex disputes. Therefore, the decision of these disputes will most likely not be made public; it will therefore be hard to understand the reasons through which the decisions are reached and how they would be applicable in different cases.

The second arbitral institution mentioned is P.R.I.M.E. Finance. Its model is the more general arbitral institution, without any formal links to government or governmentauthorized organizations. ${ }^{666}$ According to its website, P.R.I.M.E. Finance was created after discussions with various market participants and government officials in which the need for an arbitral institution focusing on complex financial transactions was recognized. ${ }^{667}$

P.R.I.M.E. finance had its opening conference on 16 January 2012 but so far its operation seems to be highly secretive as there are no reports on the amount or type of disputes that have been handled by this arbitral institution. As this is a more general arbitral institution, it is not something that should be criticized. On the other hand, such an institutional design would not be adequate as the main method of dispute resolution in a particular field of law.

${ }^{663}$ See Regulation of the Câmara de Arbitragem do Mercado, ss 3.11-3.14.

${ }^{664}$ Regulation of the Câmara de Arbitragem do Mercado, s 9.1.

665 The publicity of judicial acts is constitutionally guaranteed in Brazil. See Brazilian Federal Constitution, art 5, LX.

666 Such as stock exchanges with self-regulatory powers.

667 P.R.I.M.E. Finance, 'About Us

' (P.R.I.M.E. Finance) <http://primefinancedisputes.org/about-us/> accessed 8 July 2014. 


\section{International Models}

International dispute resolution mechanisms are those established with the authority of more than one state. ${ }^{668}$ As with national dispute resolution models, there is a wide array of different settings for international dispute resolution models.

\section{A. International Courts}

The defining characteristic of an international court or tribunal is the presence of sitting judges who are remunerated by the institution as their decision-makers. There are no other defining characteristics in the taxonomy of international organizations that can be used to make this distinction, as the other characteristic that is also used to define what is commonly understood as a court in the national sphere, compulsory jurisdiction, is not always present in the international sphere.

International courts are established by treaties. Their initial authority derives from the authority attributed to them by the states entering the treaty to establish the international tribunal. While they may broaden their power by their own operation, ${ }^{669}$ in any event, it is necessary that this is accepted by the relevant countries involved, in order for the Tribunal to continue exercising authority.

The typical example of an international court with non-compulsory jurisdiction is the International Court of Justice. ${ }^{670}$ The Court is composed of 15 independent judges. ${ }^{671}$ In a given dispute, if a country does not have a judge from its nationality as part of the Court, it may appoint an ad hoc judge. ${ }^{672}$ The use of ad hoc judges is seen as problematic because it goes against the ideal of judicial independence, even though their use is

${ }^{668}$ For the purposes of this work, the international/national division is made in accordance to the plurality of legal authority on which the dispute resolution body is based.

${ }^{669}$ For example, the ECJ. See Karen Alter, 'The European Court's Political Power Across Time and Space' (2009) Northwestern Law \& Econ Research Paper No 09-03 1.

670 Its jurisdiction becomes compulsory only when a country makes a declaration under Article 36(2) of the ICJ Statute, and only when the other country submitting the dispute for consideration has also made the same declaration.

671 They are elected by the General Assembly and Security Council of the UN for a renewable 9 year term. ICJ Statute, arts 3(1), 4(1), 13(1).

${ }^{672}$ See Ruth Mackenzie and others, The Manual on International Courts and Tribunals (Oxford University Press 2010) 6-8. 
justified as serving the 'function of maintaining the confidence of the parties in the judicial process before the ICJ.'673 The ICJ has jurisdiction over any cases between states that refer their dispute to it, and in 'matters specially provided for in the Charter of the United Nations or in treaties or conventions in force' ${ }^{674}$

The International Tribunal for the Law of the Sea also has a similar institutional design. Jurisdiction is only exercisable if accepted by state parties, judges are elected and ad hoc judges can be appointed when there are no judges from the nationality of one of the states in the dispute. ${ }^{675}$

At the other end of the spectrum, having compulsory jurisdiction over the disputes it encompasses, is the WTO Dispute Settlement Body, ${ }^{676}$ established in accordance with the Dispute Settlement Understanding. ${ }^{677}$ The DSB has the authority to establish panels and adopt reports. ${ }^{678}$ The dispute resolution procedure is embedded in a complex institutional setting and encompasses various steps before a final resolution is made. The first formal step is consultation, where the parties try to solve their disagreements without engaging in litigation. ${ }^{679}$ If consultation does not work, the second step is the establishment of a panel to decide the dispute. The panel procedure is more similar to arbitration since panelists are selected $a d$ hoc, not being part of any permanent body within the WTO organization. ${ }^{680}$ The panel decision may either be adopted by the DSB or appealed. 681

If the Panel report is appealed, then it goes to a Standing Appellate Body for review. This is where the dispute resolution system of the WTO becomes more aligned to the idea

673 Ibid 8.

${ }^{674}$ ICJ Statute, art 36(1).

${ }^{675}$ Mackenzie and others 40-44 (n 672).

676 Dispute Resolution Understanding, art 23.

677 WTO Agreement, Annex 2.

678 Dispute Resolution Understanding, art 2.1.

${ }^{679}$ Dispute Resolution Understanding, art 4.

680 There is an indicative list of panelists that is maintained by the WTO but they are not formally tied to it. For the procedure of selecting panelists, see Dispute Resolution Understanding, art 8.

681 Dispute Resolution Understanding, art 16.4. 
of a 'court' than an 'arbitral tribunal'. Appellate Body members are appointed for a fouryear term with the possibility of one reappointment. ${ }^{682}$

Panels and Appellate Body reports have to be adopted by the DSB unless there is a consensus on not adopting it. ${ }^{683}$ When a WTO member is applying measures that are inconsistent with a covered agreement, the panel or Appellate Body recommends that the Member bring the measure into conformity with the agreement. ${ }^{684}$

These decisions are binding and if the Member does not comply with them, the complainant may either request compensation to the breaching party or resort to countermeasures after authorization by the DSB. ${ }^{685}$

Even though the international court model may be adequate to solve diverse types of disputes, it might not constitute the best forum for transnational securities transactions. There are two problems that are quite clear from this model: 1) the necessity of establishing the body through a treaty, which requires spending a lot of political energy, especially with the broad scope of signatories required for a truly transnational dispute resolution system; and 2) the high maintenance costs of maintaining sitting judges and the whole structure of the body.

\section{B. International Arbitral Institutions}

The difference between International Arbitral Institutions and National Arbitral Institutions is that the former are constituted on the basis of international treaties, while the latter are constituted on the basis of articles of incorporation, in accordance with national law.

International Arbitral Institutions perform the function of administering arbitrations. They do not decide cases, but provide rules, facilities and personnel to ensure that the arbitration process follows smoothly.

\footnotetext{
682 Dispute Resolution Understanding, art 17.2.

683 Dispute Resolution Understanding, art 16.4 and 17.14.

${ }^{684}$ Dispute Resolution Understanding art 19.

685 Dispute Resolution Understanding, art 22.
} 
The two most recognized International Arbitral Institutions are the Permanent Court of Arbitration, in The Hague, and the International Centre for Settlement of Investment Disputes, in Washington.

The PCA is the oldest, established in 1899 by the Hague Conference through the adoption of the Convention for the Pacific Settlement of International Disputes. ${ }^{686}$ The ICSID was established in 1966 and the cases that it administers are more limited in scope than the PCA, being restricted to investment disputes. ${ }^{687}$

\section{The European Cross-Border Mechanism for Financial Disputes: a network of dispute resolution bodies}

The mechanism developed in Europe for cross-border consumer financial disputes involving the financial intermediary - investor type of dispute is Fin-Net, a financial dispute resolution network. It is not a dispute resolution body but only a network in which its members, national dispute resolution schemes, such as the UK Ombudsman Service, agree to cooperate with each other regarding financial disputes. For example, if an Italian has a problem with a UK financial company, the Italian may bring his problems to the Italian Dispute Resolution Body for financial disputes, who will then guide the Italian consumer to contact the UK scheme that can help him with his dispute, or it will forward the dispute directly to that scheme. 688

Clearly, Fin-Net is a cooperation forum as it only organizes and orients national dispute resolution schemes in the European Economic Area countries on how to deal with complaints that are cross-border or outside their jurisdictional scope. ${ }^{689}$

Fin-Net was created in 2001 by the European Commission. It has a very modest budget. ${ }^{690}$ The number of complaints that have been through the system is rising, from

\footnotetext{
686 Mackenzie and others 102 (n 672).

687 ICSID Convention, article 25.1.

688 See Memorandum of Understanding on a Cross-Border Out-of-Court Complaints Network for Financial Services in the European Economic Area.

${ }^{689}$ I use 'jurisdictional' here in the sense of what disputes these schemes can entertain.

690 The budget in 2008 was 65,326 Euros (DG Internal Market and Services, Evaluation of FIN-NET (Final Report June, 2009) 50).
} 
1041 in 2007 to 1854 in 2011.691 This remains a small number of cases when compared to more local dispute resolution schemes, ${ }^{692}$ which indicates that consumer cross-border financial transactions are not that common when compared to similar national transactions.

The Fin-Net was created to bring information to consumers on out-of-court redress mechanisms, to ensure information exchange between different ADRs schemes, to improve the provision of dispute resolution services and to ensure that there is a common set of principles governing the different ADR schemes. ${ }^{693}$ Basically, the broad objectives of the scheme are to 'assist consumers in the resolution of cross-border disputes' and to 'raise consumer confidence in buying financial services cross-border'.694

The positive aspect of Fin-Net is that it provides information and mechanisms, through local ADR schemes, to consumers on how to obtain redress on cross-border financial transactions and it does this at a low cost. By improving the prospect of information access and redress, this scheme is helpful in increasing confidence in the market for cross-border financial transactions.

The negative aspect of the scheme is that it does not go far enough. Despite improving information and redress mechanism access, these ADR mechanisms vary depending on the jurisdiction at stake. They have a widely different range, from nonbinding to binding and from private-based to public-based. ${ }^{695}$ Someone who would like to engage in a cross-border financial transaction would have to perform a detailed study of the redress mechanisms that are available in the countries in which the investor would like to invest, defeating, at least to some extent, the purpose of the Fin-Net network itself. If someone has the need to look for information beforehand to be protected, a network that provides information would then become less useful, as the investor who has done his homework would already have it.

\footnotetext{
${ }^{691}$ European Commission, FIN-NET Activity Report 2011 (June 2012).

${ }^{692}$ For example, the UK Financial Ombudsman Service dealt with 508,881 formal disputes in the 2012/2013 year (See , 'Annual Review 2012/2013').

${ }^{693}$ DG Internal Market and Services, Evaluation of FIN-NET (Final Report June, 2009) 8.

694 Ibid 9.

695 Ibid 19.
} 
Even though Fin-Net is a step forward in increasing confidence in markets through the provision of more information about the functioning of dispute resolution in financial transactions within the European context, the construction of a single market would profit from a European-wide dispute resolution system, or at least systems connected by the network that are similar in how they operate.

\section{Implications}

\section{A. General Implications}

A serious dispute resolution system for securities transactions has to provide a high degree of certainty on its outcomes based on clear rules that are known by the parties before they engage in a transaction. In a perfect world, dispute resolution systems would operate only for enforcement of decisions, as everyone would know beforehand what the decision would be. Certainty requires institutional structures to isolate the decisionmaker from unwarranted external influence, be it from the political process or from parties to the dispute; yet at the same time, checks and balances are necessary to avoid that the decision maker goes rogue, becoming the tyrant himself.

A consequence of the need for certainty in the legal system and the dispute resolution process is the need for reasoned decisions. Legal rules may need to be interpreted due to the impossibility of having ex ante a complete set of rules that would apply seamlessly to every single situation, creating the need that for every dispute, which by definition involves uncertainty, ${ }^{696}$ a decision is made to clarify the status of the law. The development and functioning of the dispute resolution system based on legal mechanisms therefore also depends on reasoned decisions.

Finally, the cost of the system should be as low as possible while providing the necessary certainty for the dispute resolution process. High costs of access limit the availability of the system to those who have fewer resources, excluding them from the possibility to use formal redress mechanisms. This consequently removes confidence in the market as investors may feel helpless when facing unjust situations without having a

\footnotetext{
${ }^{696}$ Apart from cases where one of the parties simply refuses to pay.
} 
forum for the discussion of their dispute. As lack of confidence in a market may create the lemons problem, it is better if a properly structured system is in place. There is a prior question that arises concerning the desirability of having low asset investors in financial markets; this is not a question that this work is trying to answer. Nevertheless, to the extent that low asset investors are included in the securities market, proper means of redress have also to be made available.

Some of the alternative systems discussed in this chapter have these characteristics. The UK Ombudsmen Service, for example, is free for the complainant, provides fast decisions and provides reasons for the decisions, even though the decisions are not legally justified. ${ }^{697}$ The drawback of the system is that, with a more simple design than a full court procedure, it deals only with limited types of cases, namely those involving investors and financial intermediaries, up to the limit of $£ 150.000$.

For a dispute resolution system to be an efficient tool for transnational securities transactions, all of the characteristics discussed above have to be included in its design, so the objectives of access to justice and legal certainty can be achieved.

\section{B. EU Implications}

In respect of the cross-border provision of financial services, the EU already has in place a solution for the transnational problem, which is the coordination of different outof-court dispute resolution system for financial consumer transactions. Even though this might be a very simple mechanism, it seems to be adequate for current EU needs, at least in the investor-financial intermediary type of dispute. The problems of certainty and access to the dispute resolution system would therefore have to be discussed on a caseby-case basis, depending on the EU Member State being analyzed. The difference between the out-of-court settlement procedures could create distortion in competition, as the level of justice provided would differ. For example, in Italy the out-of-court dispute resolution system is not binding, while in the UK it is, as long as the consumer accepts the decision. Therefore, some kind of harmonization and similarity in access to justice and in the

697 There has been a trend towards more justification in the UK Financial Ombudsmen Service decisions, but the downside is that too much formalization may increase the amount of time necessary for a decision to be made. 
consequences of the dispute resolution process, are objectives that should be pursued to normalize legal redress and to guarantee a level playing field for different investors within Europe.

Outside the financial consumer context, the dispute resolution method in Europe is also local, but based on national courts. The interaction among EU members' courts is done through the European International Private Law mechanisms, a regime that can create some legal certainty problems in transnational securities transactions, as will be explained in Chapter X. 


\section{Chapter VIII - Aggregate Litigation Design}

Civil procedure is a defining aspect of litigation in general. The mechanisms available to the parties and the rules of procedure are always taken into account when deciding whether to engage in litigation.

Aggregate litigation mechanisms can play an important part in the determination of what cases go forward and who is able to obtain redress from an act that caused harm to a party. The bundling of economic incentives from different parties and the enrollment of a third party in the economic benefits that may accrue from the lawsuit can unlock justice for people that would otherwise not be able to achieve it. ${ }^{698}$ Aggregate litigation can be a particularly good solution in securities disputes; especially those involving the disputes between issuer-investor and information intermediary and investor, due to the widespread effects that false or misleading information may have on the market, linking all claims by the same facts.

Procedural aspects are as important as substantive ones in the operation of the legal system; 'the mechanisms of law - what courts are to deal with which causes and subject to what conditions - cannot be dissociated from the ends that law subserves'. ${ }^{699}$ Aggregate litigation mechanisms can be an interesting option for access to justice and the enforcement of substantive law, but their design may encounter constitutional limits based on juridical values such as fairness and due process, which vary depending on the specific legal system under consideration.

The broad questions that aggregate litigation design has to solve are twofold: 1) how to design proper incentives for claims to be brought forward without overburdening

698 ('By combining the stakes of many plaintiffs, collective representation provides group lawyers sufficient incentive to invest heavily in the litigation. It allows lawyers to take advantage of economies of scale, reducing the per-plaintiff cost of litigating.') Howard Erichson, 'Beyond the Class Action: lawyer loyalty and client autonomy in non-class collective representation' [2003] 2003 University of Chicago Legal Forum 519, 576.

${ }^{699}$ Stephen B. Burbank, 'The Class Action Fairness Act of 2005 in Historical Context: a preliminary view' (2008) 156 University of Pennsylvania Law Review 1439, 1439. 
possible defendants due to too many unsubstantiated claims ${ }^{700}$ and 2) how to achieve finality on a particular dispute. Even though the focus of this work is on securities disputes, the discussion on aggregate litigation has a more general tone. The question that this chapter addresses is: 'how can aggregate litigation be used to solve securities disputes?'

The objective of this chapter is to establish a framework to analyze aggregate litigation and understand how it can be applied in securities disputes. The chapter is divided in two parts: 1) aggregate litigation design and 2) the role of aggregate litigation in securities disputes.

\section{Aggregate Litigation Design}

Aggregate litigation mechanisms can be designed to achieve diverse goals, such as access to justice, enhancing the economy and regulation through litigation, amongst other means. ${ }^{701}$ The two basic goals that aggregate litigation can accomplish are deterrence and compensation, ${ }^{702}$ in addition to saving public resources due to widespread litigation. The discussion of this thesis focuses more on aggregate litigation as a means of compensation and access to justice, than on deterrence; this second goal is a matter more closely related to the prevention of abuses and law enforcement - the broader regulatory design of securities regulation - than to dispute resolution and redress. Even though aggregate litigation has been around the U.S. for some time, it has recently become an important topic in the European context. ${ }^{703}$

Conceptually, aggregate litigation is a mechanism where a decision issued by a court binds many persons. It becomes especially relevant when private claims are of so little value that no single litigant would engage in litigation to have his rights protected

\footnotetext{
700 Alexander Layton, 'Collective Redress: policy objectives and practical problems' in Duncan Fairgrieve and Eva Lein (eds), Extraterritoriality and Collective Redress (Oxford University Press 2012) 94.

${ }^{701}$ Hodges, The Reform of Class and Representative Actions in European Legal Systems 187-222 (n 604).

702 Christopher Hodges, 'Objectives, mechanisms and policy choices in collective enforcement and redress' in Jenny Steele and Willem H. van Boom (eds), Mass Justice: challenges of representation and distribution (Edward Elgar 2011) 102 Geoffrey Miller, 'Compensation and Deterrence in Consumer Class Actions in the US and Europe' in Fabrizio Cafaggi and Hans-W. Micklitz (eds), New Frontiers of Consumer Protection: the interplay between private and public enforcement (Intersentia 2009) 264-66.

703 See Commission, 'Towards a European Horizontal Framework Collective Redress' (Communication) COM (2013) 401 final, 2013.
} 
because it would be more expensive in respect of time and/or money than to do nothing, as a result of the small value of the claim or the value of the claim minus the cost of litigation. ${ }^{704}$ By allowing the claims to be put together and litigated as a group, the total value of the pie increases. As long as the total value that can be recuperated is higher than the costs of bringing the suit, there are sufficient incentives for the claim to be litigated; the bigger the group of claims, the bigger the incentive. Even claims that could be litigated individually could also be grouped as there would be more resources for the lawsuit and the transaction costs would be smaller than if litigation was pursued on an individual basis.

So far, there are two main actors that can be identified in the plaintiff's side: the owners of the claims that will be grouped and the agent that will coordinate the litigation efforts on the part of the plaintiffs.

This second player in the plaintiff's side of the aggregate litigation game, the one who may benefit from the lawsuit in addition to the claim owners, constitutes a necessary piece of the puzzle as claimants themselves would otherwise have no interest in pursuing the litigation due to its cost. ${ }^{705}$ This player might have a private role, seeking profit from the activity, or a public one, seeking to correct a wrongful act or be in charge of enforcing the law. ${ }^{706}$ Its role can be either to coordinate the lawsuit and seek the most appropriate redress for the case or to provide funding when necessary; sometimes its role reflects both.

This private party can either be the lawyer, who will receive money from the service performed for the group, or a third-party funder, who will provide money for the costs of the lawsuit. The incentives can be either the return on the investment from the

704 This is the concept of a negative claim. See Robert Cooter and Thomas Ulen, Law and Economics (5th edn, Pearson Addison Wesley 2008) 420-23.

705 This is part of the collective action problem, where even though it is beneficial for the members of a group to act in conjunction to achieve their own common goal, they fail to do so. See generally Mancur Olson, The logic of collective action: public goods and the theory of groups (Harvard University Press 1971).

706 The interest can be either because it is its institutional function to do so, such as the Public Ministry in Brazil, or because it is an association with a specific public interest goal. 
lawsuit, or the sense of duty performed if the party is an association that has as its mission the defense of a particular group. ${ }^{707}$

Depending on the identification of the manager/financier of the litigation and the different interest positions of group members, different conflicts of interest may arise. The first aspect of an aggregate litigation design revolves around the incentives of the parties to bring the claim forward, the costs of the lawsuit and the conflicts between those different players. Within this context, there are additional concerns that come into play, as the financial aspect is not the only one that influences the possibilities of aggregate litigation. Ethical rules of the legal profession can also limit the schemes that can be designed for aggregate litigation and for financing incentives.

The second consideration, closely tied to the first, concerns whether the mechanism of aggregation will be an opt-in mechanism or an opt-out one. An opt-in mechanism requires each claimant to express their desire to participate in the lawsuit and to be bound by it, while the opt-out procedure binds absent claimants without their consent. This characteristic of the opt-out procedure also has implications for conflict of interest analysis, but this option is not available to every single legal system due to constitutional limitations. ${ }^{708}$

Due to this, aggregate litigation differs widely in practice, especially when contrasting the American Class Action system with civil law systems; notwithstanding, the underlying problems that these systems are designed to solve are similar. This section analyzes the $(\mathrm{A})$ conflicts in the relationships among the different parties involved in aggregate litigation, (B) ethical limitations on aggregate litigation and the (C) limitations on choosing the opt-in or opt-out character. This section does not attempt to exhaustively cover the subject, but only to give a broad overview of the main issues that are present in aggregate litigation design and its possible limitations.

\footnotetext{
707 The availability of these mechanisms is highly jurisdiction specific due to differences in procedural law and ethical standards for lawyers.

708 Opt-out procedures are allowed in some Common Law jurisdictions such as the U.S., Canada and Australia. See Rachael Mulheron, The Class Action in Common Legal Systems (Hart Publishing 2004) 5-15.
} 


\section{A. Conflicts in Aggregate Litigation}

The purpose of an aggregate litigation system is to allow for litigation that otherwise would not exist due to cost/benefit constraints, or at least improve the economies of scale of it. Due to the inherent tensions of agency-principal relationships, exacerbated by the multiple claimants setting, aggregate litigation presents a wide array of conflict of interest problems. 709

These conflicts can be divided into three groups: (a) conflicts between the lawyer and plaintiffs, (b) conflicts within the group and (c) conflicts involving third-party financiers.

\section{a. Conflicts between Plaintiffs and Lawyer}

The role of lawyers in legal disputes is to advise what the best course of action for a particular problem is and to represent the client in litigation if necessary. To perform this role, lawyers expect to be compensated, and there is a wide array of different schemes that can be designed for this purpose. The commonly-used schemes are the contingent fee, the hourly rate and the fixed sum.

In the contingent fee 710 arrangement, the lawyer is paid a part of the plaintiff's recovery, becoming directly interested in a high outcome for the client. Even though their interests seem to be aligned, the alignment is not a complete one when a settlement possibility is introduced into the equation. If lawyers have the power to settle, they may

\footnotetext{
${ }^{709}$ See Jenny Steele and Willem H. van Boon, 'Mass Justice and its Challenges' in Jenny Steele and Willem H. van Boon (eds), Mass Justice: challenges of representation and distribution (2011) On conflicts regarding the class action, see Geoffrey Miller, 'Conflicts of Interest in Class Action Litigation: an inquiry into the appropriate standard' [2003] 2003 University of Chicago Legal Forum 581, 581-90 More generally on the conflict of interest problems, see John Armour, Henry Hansmann and Reinier Kraakman, 'Agency Problems and Legal Strategies' in Reinier Kraakman and others (eds), The Anatomy of Corporate Law: a comparative and functional approach (2nd edn, Oxford University Press 2009) On the conflict of interest problems when there is legal representation by a public officer, see Margareth Lemos, 'Aggregate Litigation Goes Public: Representative Suits by State Attorneys General' (2012) 126 Harvard Law Review 486.

${ }^{710}$ For some examples of where the contingent fee arrangement is allowed, see Herbert M. Kritzer, Risks, reputations, and rewards: contingency fee legal practice in the United States (Stanford Law and Politics 2004) 258-59.
} 
be tempted to settle early to avoid costs of litigating, even though litigation might be more economically efficient to the client. ${ }^{711}$

In the hourly fee arrangement, the lawyer will sell his time and work by the hour, receiving a fee according to the amount of time that was dedicated to the case. This scheme does not combine with lawyer control for settlement, as the lawyers will have the incentive to go to trial to spend as many hours as possible working on the case. ${ }^{712}$

Finally, in the fixed sum agreement, the lawyer will receive what has been agreed in the contract with the client, regardless of the outcome of the case; the lawyer has the incentive to work as little as possible for the benefit of the client, settling at the first possible opportunity.

As long as the plaintiff has an important stake in the litigation and the information asymmetry between lawyer and plaintiff is low, the selection of the lawyer compensation scheme will not be a very important problem as both parties will be able to strike a deal that is in their best interest. Conflict of interest problems start to become serious when the monitoring power of plaintiff(s) over the lawyer diminishes.

This is the case in situations where aggregate litigation is most adequate, as plaintiffs tend to be less well informed ${ }^{713}$ and have a weakened lawyer-client relationship due to the amount of similar cases that lawyers are handling and the small interest of each client compared to the overall amount at stake. ${ }^{714}$ To a certain extent, market incentives take care of this problem. As these tend to be claims that would not be pursued by each claimant alone, it is unlikely that they would be willing to pay upfront for the litigation, or commit to pay an hourly fee to the lawyer by whom they are being represented, leaving the contingent fee as the lawyer compensation scheme of choice, which aligns the interest

\footnotetext{
711 See Geoffrey Miller, 'Some Agency Problems in Settlements' (1987) 16 Journal of Legal Studies 189, 198202. The author in this article explains that any system besides the contingent fee system where the plaintiff has control over settlement tend to be non-optimal.

712 Ibid 203-04.

713 The information asymmetry comes from the fact that lawyers will understand better the chances of success of the lawsuit, whether due to their legal experience or due to their knowledge of the facts surrounding the case.

714 ('Moreover, although aggregating clients makes litigation economically viable and more efficient, it makes effective client monitoring nearly impossible'). Elizabeth Chamblee Burch, 'Litigating Together: social, moral, and legal obligations' (2011) 91 Boston University Law Review 87, 97.
} 
of lawyers with those of claimants, even though not perfectly. ${ }^{715}$ The decision of the lawyer in taking a case in these circumstances will depend on the profit that he will make; this is a function of the number of claims he can aggregate and the percentage he would be able to take home, which depends on the availability of an opt-out mechanism and on ethical obligations, both regarding solicitation and the manner in which the lawyer can charge the clients. ${ }^{716}$

\section{b. Conflicts between Group Members}

Different group members may have different interests, economic or personal, even if the claims are based on the same factual circumstances giving rise to liability.

An example of diverse economic interests in securities litigation can be seen in a case where false or misleading statements were used to inflate the securities price and in which, posteriorly, there are various securities price drops after several curative disclosures made during an extended period of time. In this situation, there will be a difference of interest between those who bought the security after one of these disclosures and those who sold it. ${ }^{717}$ While the buyers will want to maximize price inflation in the litigation so that they will receive more due to the stock price decrease, sellers will want to minimize it since this will also maximize their recovery. ${ }^{718}$

Interests may also differ depending on the cohesion and goals of the individuals that may be part of the group, which leads to different perspectives and expectations about the autonomy of the lawsuit and its outcome, having consequences in respect of how the solutions for aggregate litigation should be designed regarding procedural fairness. Between the two extremes of individual litigation and class litigation (opt-out procedure), the concepts of individual-within-the-collective and group-oriented

\footnotetext{
715 The litigation becomes a joint venture where the lawyer assumes the costs and shares the benefits of the outcome, becoming the agent and the creditor of the clients at the same time, which creates an incentive to pay attention to stronger cases and settle quickly weaker cases. Ibid 97-98.

716 See section B below for a discussion on ethical limitations.

717 This example is based on Seagate Technology II Securities Litigation, 843 F. Supp. 1341 (N.D. Cal., 1994).

${ }^{718}$ See Miller, 'Conflicts of Interest in Class Action Litigation: an inquiry into the appropriate standard' 594 (n 709).
} 
individuals, can be used as a basis for the discussion. ${ }^{719}$ While in the first claimants are strongly tied due to overlapping egocentric interests and/or joint intent, ${ }^{720}$ in the second they are mainly self-interested but might have advantages in terms of acting collectively. ${ }^{721}$

In this second case, plaintiffs may have different approaches in respect of how they would prefer to pursue the case and as to their different risk tolerances; this would lead to different strategies for each plaintiff. The problem is that to profit from the lawsuit collectivization, some of the plaintiffs would have to give away their autonomy and their preferences to be able to participate in the process. ${ }^{722}$ When designing aggregate litigation procedures, these differences have to be taken into consideration, allowing different groups to exercise their different preferences.

\section{c. Third-Party Financiers}

One recent development in the legal market that has been getting increasing academic attention is the use of third-party financiers to finance litigation. The enrollment of third-party financing has the advantage of dismantling the double role that lawyers play - as both financier and agent - in many procedures of aggregate litigation, while it also engages a more sophisticated party and someone with more at stake in the litigation to monitor the lawyers; ${ }^{723}$ moreover, it broadens the opportunities for costly litigation to proceed when lawyers are not comfortable enough to risk their assets in a specific case.

The downside of a third-party financier is that another party is added to the already complex conflict of interest matrix that is present in litigation. One of the practices of consumer litigation lenders is to lend money on a non-recourse basis, having only the outcome of the litigation as the source of future repayment. ${ }^{724}$ In a case, a third-party

\footnotetext{
719 Elizabeth Chamblee Burch, 'Procedural Justice in Nonclass Aggregation' (2009) 44 Wake Forest Law Review 1, 11-24.

720 Ibid 16.

721 Ibid 20.

722 Ibid 22.

723 Elizabeth Chamblee Burch, 'Financiers as Monitors in Aggregate Litigation' (2012) 87 New York University Law Review 1273, 1277.

${ }^{724}$ Other practices can be commercial lending, also recovering the investment from the outcome of the lawsuit, or lending money to the law firms involved in the litigation at high interest rates. See ibid 1301-04.
} 
financier provided $\$ 200.000$ to a plaintiff expecting to receive $\$ 600.000$ plus a percentage of the recovery; this led the plaintiff to reject a $\$ 1.000 .000$ dollar offer to settle. ${ }^{725}$ The lawyers were not pleased, as they were going to be paid on a contingent-fee basis, and sued the financing company. ${ }^{726}$

Moreover, in these schemes, even though the lawyer loses some of the conflicts that were present before as a result of the contingent-fee system, these conflicts are simply transported to the financier, who will have similar incentives as the lawyer to suggest a quick settlement. The lawyer would then have a divided loyalty to the client, who he is supposed to represent, and the financier, who is a repeat player and might bring more business to the lawyer.

In any event, the use of external litigation finance may be beneficial. For example, Professor Molot suggests that allowing third-party finance empowers plaintiffs by providing alternatives to settlement with the defendant, creating a market for claims that would increase the efficiency of settlements by allowing transactions that would reflect to a greater extent the merits of the case than simply the bargaining power of the parties. $^{727}$

\section{d. Conflicts in an Opt-Out Procedure}

The most famous system of an opt-out procedure is the American class action. In an opt-out procedure, the concerns about conflicts of interest are even more acute than in opt-in aggregate litigation since the decision of the court binds absent parties, some of whom would not even know they are involved in a litigation or that they could be bound by it. The legitimacy of the decision becomes the central problem in these mechanisms.

The legitimacy of a judicial decision is usually guaranteed because the parties to a dispute have the right and opportunity to participate in the judicial process, presenting its case and defending it in front of an impartial judge, who will issue a reasoned decision.

\footnotetext{
${ }^{725}$ See Weaver, Bennett \& Bland, P.A. v. Speedy Bucks, Inc., 162 F.Supp. 2d 448 (W.D.N.C. 2001).

726 Ibid.

${ }^{727}$ See Jonathan Molot, 'Litigation Finance: a market solution to a procedural problem' (2010-2011) 99 Georgetown Law Journal 65.
} 
The guarantee of someone's 'day in court'728 is one of the tenets of the principle of due process of law, legitimating the final decision reached by the court. ${ }^{729}$ Parties consent to being represented by a lawyer of their choice and to engaging in litigation.

The central added value of the opt-out procedure mechanism is exactly the absence of this guarantee, binding persons that were not part of the judicial proceeding. This increases the economic benefits of aggregation, since all of those who have a similar case will be bound by the decision. ${ }^{730}$

The same conflicts of interest that are present in normal aggregate litigation are also present in opt-out procedures, such as collusion between class counsel and defendants, with class counsel striding away from its duty to represent plaintiffs' interests, leading to unfair settlement agreements. ${ }^{731}$ The important background question to the opt-out procedure, which has a link with the operation of preclusion principles, is how can a judicial decision legitimately bind someone who has not participated in the proceedings?

Operationally, the answer to this question lies in the use of alternative legitimating mechanisms, which, in the classic class action/corporate governance literature, are typified as voice, exit and loyalty. ${ }^{732}$ At its core, this is a governance design problem, ${ }^{733}$

${ }^{728}$ In the U.S., the Supreme Court was explicit about the right of a 'day in court' in Martin v. Wilks, 490 U.S. 755, 762 (1989).

${ }^{729}$ The right to be heard guaranteeing the legitimacy of a judicial decision may even have constitutional status in some countries. The Brazilian Constitution, for example, provides that 'the law won't exclude from judiciary appreciation a harm or threat to a right' (art $5 \mathrm{XXV}$ ) and 'no one will be deprived of liberty or property without due process' (art 5 LIV). See also Phillips Petroleum Co. v. Shutts, 472 U.S. 797 (1985).

730 'The policy at the very core of the class action mechanism is to overcome the problem that small recoveries do not provide the incentives for any individual to bring a solo action prosecuting his or her rights. A class action solves this problem by aggregating the relatively paltry potential recoveries into something worth someone's (usually an attorney's) labor.' Mace v Van Ru Credit Corp., 109 F3d 338, 344 (7th Cir 1997).

731 '[S]ome defendants who face stronger claims may seek out plaintiffs' attorneys who are willing to settle such claims at less than their true value in exchange for fees that arguably are more generous than they deserve, given what they have obtained for their class clients'. Deborah R. Hensler and Thomas D. Rowe, 'Beyond "It Just Ain't Worth It": Alternative Strategies for Damages Class Action Reform' (2001) 64 Law and Contemporary Problems 137, 138.

${ }^{732}$ See John C. Coffee, 'Class Action Accountability: Reconciling Exit, Voice and Loyalty in Representative Litigation' (2000) 100 Columbia Law Review 370; Albert O. Hirschman, Exit, Voice, and Loyalty: Responses to Decline in Firms (Harvard University Press 1970).

733 See Issacharoff (n 604). 
which involves the main players of the civil justice system and their incentives to act. ${ }^{734}$ In the U.S., contrary to other common principal-agent situations that are extensively regulated by legal standards and have legitimacy mechanisms to control the agent's behavior, such as in corporate law and bankruptcy law, in the opt-out procedure context, they are either lacking or are inadequate to address the conflict issues that arise. ${ }^{735}$

From a normative perspective, the basis for legitimizing a decision for a person that has not had their 'day in court' are consent, majoritarian control, prior association/community of interests and homogeneous preferences. ${ }^{736}$ The strength of these bases varies and is dependent on the circumstances. The strongest is consent; someone who consented to participate in a proceeding knowing beforehand that the results of it will have concrete effects, will be more likely to accept the decision as legitimate. ${ }^{737}$ The prior association/community of interests basis may be more appropriate as a normative argument to bind a community that share the same interests, inherent from the status of the group. ${ }^{738}$ The majoritarian control basis is either linked to consent, through a contractual framework where a representative entity is created, or on other policy goals, when the entity created for representation has a basis on statutory provisions, such as a consumer association. Finally, homogeneous preferences can be justifiable to bind absent members, to the extent that their claims and preferences are in fact 'homogeneous', demonstrating that the different class members have aligned interests.

${ }^{734}$ Deborah R. Hensler, Class Action Dilemmas: Pursuing Public Goals for Private Gains (RAND Institute for Civil Justice, 1999) 8-23.

${ }^{735}$ See Coffee, 'Class Action Accountability: Reconciling Exit, Voice and Loyalty in Representative Litigation' 376 ( $\mathrm{n}$ 732). (Criticizing the governance mechanisms to reduce agency costs identified by Jensen \& Meckling as inadequate in the class action context.) See also Michael C. Jensen and William H. Meckling, Theory of the Firm: Managerial Behavior, Agency Costs and Ownership Structure' (1976) 3 Journal of Financial Economics 305.

${ }^{736}$ Coffee, 'Class Action Accountability: Reconciling Exit, Voice and Loyalty in Representative Litigation' 380-85 (n 732).

737 The problem with consent in opt-out procedures boils down to what constitutes consent - the opt-out procedure assumes consent was given if the person has not opted-out, therefore other guarantees are built to legitimize the decision, such as the requirement of adequate representation. Ibid 381.

${ }^{738}$ For example, a decision binding asbestos victims only based on a prior association/community of interests criteria would hardly be seen as legitimate if every single person didn't consent to it or had the opportunity to participate in the proceedings since the consequences of asbestos exposure vary greatly from victim to victim. 
The consent basis, usually the strongest one to legitimize a judicial decision, has a lesser role in the case of the opt-out procedure; at the same time, other bases are used to make the decision more legitimate.

The logic of the benefits of aggregate litigation apply even more to the case of the opt-out procedure; as class members do not have an actual interest in pursuing the lawsuit on an individual basis due to its value or its cost, someone has to take the lead. This is a job usually done by class counsel, who acts as the propelling engine for the litigation by seeking situations in which class actions could be brought and by financing it. ${ }^{739}$ Litigation is highly expensive in the United States, and by assuming the costs, lawyers invest a significant stake in the class action, ${ }^{740}$ frequently having a much higher interest in the outcome of the dispute than class members themselves. ${ }^{741}$ As class members have a small stake in the dispute, their incentive to monitor lawyers is also small; this often means that lawyers end up being free to act as they please. ${ }^{742}$

The incentives therefore are a clear departure from the classic representative role of the lawyer. Class counsel will perform in court rather with his own interests in mind than with those of the class; the plaintiffs become a mere conduit for the lawyer to play his role. In many types of cases, this is not a serious problem since class members either accept their condition of claimants, with the possibility of receiving a small sum at the end of the litigation, or they exercise their right to opt out and receive nothing. The stakes are so low that it is not economically profitable for a claimant to pursue the claim on his

\footnotetext{
${ }^{739}$ One author explained that class actions are 'characterized by a rent-seeking entrepreneur pursuing her own interests with little oversight by her principals.' William B. Rubenstein, 'On What a "Private Attorney General" Is - And Why it Matters' (2004) 57 Vanderbilt Law Review 2129, 2162-63.

${ }^{740}$ Class action lawyers have been seen as self-interested entrepreneurs for quite a long time. See John C. Coffee, 'The Regulation of Entrepeneurial Litigation: Balancing Fairness and Efficiency in the Large Class Action' (1987) 54 University of Chicago Law Review 877.

741 Of course, this is not always the case; many class actions involve highly emotionally charged situations such as in asbestos litigation - in which the class representatives would clearly have an interest in the outcome of the dispute that surpass mere economic recovery. These cases though tend to involver higher stakes for class members than other more simple consumer cases.

742 '[P]laintiff's class and derivative attorneys function essentially as entrepreneurs who bear a substantial amount of the litigation risk and exercise nearly plenary control over all important decisions in the lawsuit.' Jonathan R. Macey and Geoffrey P. Miller, 'The Plaintiffs' Attorney's Role in Class Action and Derivative Litigation: Economic Analysis and Recommendations for Reform' (1991) 58 University of Chicago Law Review 1, 3.
} 
own. ${ }^{743}$ Even if lawyers are thinking about themselves and profiting more than they should be entitled to, claimants are still better off in this situation than otherwise. Legitimacy here is based both on consent ${ }^{744}$ and homogenous preferences, ${ }^{745}$ even though the consent basis is extremely weak, since it is a presumption that a class member has indeed learned about the litigation and decided not to opt-out.

Conflicts exist that are specific to the opt-out procedure; this includes the 'reverse auction' practice, where there are many class actions on the same subject matter and defendant's counsel seeks the best settlement deal by 'shopping' options among different class counsels. ${ }^{746}$

Another problem arises when members of the class, individually considered, have a stronger economic interest than the rest of the members and would prefer to pursue the litigation themselves. ${ }^{747}$ In such situations, the class action mechanism shifts from being the plaintiffs' sword and may become defendants' shield. ${ }^{748}$ As they have higher stakes, particular class members may disagree with class counsel on the direction of the lawsuit; however, depending on how far the procedure has already been developed, they may not be able to opt out. Since disagreements may occur when the procedure is more advanced and plaintiffs may not opt-out anymore, class members may be precluded from litigating their rights to the fullest extent. ${ }^{749}$ In this situation, the normative legitimacy grounds are weak; they are based solely on inferred consent from a failure to opt-out at an ex ante moment when it was not clear that class counsel would not represent adequately the interests of the particular class member.

\footnotetext{
743 See Myriam Gilles and Gary B. Friedman, 'Exploding the Class Action Agency Costs Myth: the Social Utility of Entrepreneurial Lawyers' (2006-2007) 155 University of Pennsylvania Law Review 103, 132-36.

${ }^{744}$ Consent here is based on the decision of not opting out of the class action. Of course, this presumption of consent is problematic because the parties may not have had a real chance to know the possible claims to which they might be entitled. Such justification only has some appeal in situations where claimants would not have otherwise had an interest in pursuing the claim themselves.

745 By having a preference in receiving something rather than nothing.

746 Gilles and Friedman 161-62 (n 743).

747 John C. Coffee, 'Class Wars: the Dillemma of the Mass Tort Class Action' (1995) 95 Columbia Law Review 1351, 1351-52.

748 Ibid 1350.

${ }^{749}$ See Coffee, 'Class Action Accountability: Reconciling Exit, Voice and Loyalty in Representative Litigation' 419-25 (n 732).
} 
Therefore, some conflicts of interest can be present specifically on the opt-out mechanism of aggregate litigation. These conflicts have to be considered so they can be addressed in any new design of an opt-out system.

\section{B. Ethical Limitations}

Aggregate litigation can be an interesting alternative for litigating securities claims and for providing access to justice to investors; however, the manners in which claims can be financed and aggregated can be drastically limited by the ethical obligations of the legal profession in different countries.

Rules on champerty and maintenance, 750 client solicitation, attorney-client relationship and attorney-third party relationship can all be impediments to the formation of a group for litigation purposes.

Champerty and maintenance rules limit how lawyers and third parties can participate in the funding of a lawsuit and how they can influence its direction. ${ }^{751}$ If the lawyers and third parties are limited to too great an extent, no one will be willing to assume any of the risks of litigation, either because it is outright prohibited or because the control over the litigation becomes too narrow and the investment becomes too risky.

Rules on client solicitation preclude lawyers, or even third parties, from searching and engaging clients to initiate the lawsuit. This is true in Brazil, where it is forbidden for a lawyer to 'recruit or capture cases, with or without the help of a third party' ${ }^{752}$ Any active attempt to amass a critical number of similar cases for litigation will be seen as an ethical violation; this renders it almost impossible for a private lawyer to pursue litigation where the value for each claimant is low.

\footnotetext{
${ }^{750}$ Maintenance is the 'assistance in prosecuting or defending a lawsuit given to a litigant by someone who has no bona fide interest in the case [or] meddling in someone else's litigation' and champerty is '[a]n agreement between an officious intermeddler in a lawsuit and a litigant by which the intermeddler helps pursue the litigant's claim as consideration for receiving part of any judgment proceeds'. Anthony Sebok, 'The Inauthentic Claim' (2011) 64 Vanderbilt Law Review 61, 72-73 (Citing Black's Law Dictionary 9th ed. 2009).

751 Ibid 109.

752 Law 8.906/1994, art 34, IV.
} 
Other types of prohibitions might also limit the compensation design that could further the plaintiffs' interests in aggregate litigation; these include the prohibition on lawyers providing cash to clients for their claims and the prohibition against lawyers sharing fees with non-lawyers. ${ }^{753}$

I do not imply here that all of these limitations are bad, as some have their foundations in convincing policy rationales; ${ }^{754}$ however, their existence limits mechanisms that could be used by lawyers and other third parties to stimulate the aggregation of claims in cases that otherwise would not be litigated, opening up the access to justice and generating an efficient mechanism for compensation.

\section{Preclusion Principles and Limits on Choosing an Opt-in or Opt-out Mechanism}

Aggregate litigation can be based either on an opt-in system, where claimants express their consent in being bound by the decision by initiating the lawsuit, or an optout procedure, where the decision involving a class binds all members of the class even though specific consent was not given.

While an opt-in procedure guarantees each person the right over his or her claim and to be bound by the decision only if consent is expressly given to participate in the litigation, the opt-out procedure disposes of mass questions collectively and more efficiently, as it definitely solves and binds all those that might have been involved in a given dispute, even if consent is not given.

The possibility of using one of the systems is closely tied to the operation of preclusion; each legal system has its own preferences of what normative basis should be accepted. Common law systems are more lenient in what to accept, ${ }^{755}$ while civil law systems tend to be more conservative, limiting the scope of preclusion in aggregate litigation to very specific circumstances. The choice of one system or another is not only a matter of policy design. Underlying the discussion there are constitutional limits that

\footnotetext{
753 Molot 109-11 (n 727).

${ }^{754}$ For example, the prohibition on sharing fees with non-lawyers allows lawyers to remain independent from outside influence. Ibid 110.

${ }^{755}$ Mulheron (n 708).
} 
vary widely depending on the jurisdiction; these are imposed through the operation of preclusion.

\section{a. The Operation of Preclusion - general aspects}

Preclusion is the backbone of any legal procedure, including those of collective redress. The concept of preclusion is essential to the construction of a dispute resolution method capable of putting an end to disputes. It prevents the re-litigation of claims and issues already decided by a court, bringing stability to the relationship between the parties to a dispute. Preclusion guarantees that the parties will be able to rely on a judicial decision. A party that prevails on a claim will not have to worry about being brought to court in respect of the same disagreements, over which a decision has already been rendered, providing social pacification. To understand the operation of a collective redress system and the choice between an opt-in and an opt-out procedure, a general understanding of the rules of preclusion and its limits are necessary.

The scope of preclusion varies depending on the jurisdiction, usually being more expansive in common law countries and more restricted in civil law ones, even though there have been some recent expansionist changes in the latter. ${ }^{756}$ The basic questions addressed by the doctrine concern who is bound by the decision and what legal questions and factual issues are encompassed by it.

There is a tension between preclusion and fairness of legal proceedings ${ }^{757}$ and every legal system has to strike a balance between the two, especially because the second is a tenet of the Rule of Law concept. ${ }^{758}$ This balance is usually struck through the requirements for the operation of claim preclusion, which are mutuality, identical causes of action and that a judgment on the merits of the dispute..$^{759}$

\footnotetext{
756 See Linda Silberman, 'Preclusion Doctrine' in Oscar G. Chase and Helen Hershkoff (ed), Civil Litigation in Comparative Context (Thomson West 2007) 458; 61.

757 Edward D. Cavanagh, 'Issue Preclusion in Complex Litigation' (2009-2010) 29 The Review of Litigation 859, 870-71.

758 Maintaining the Rule of Law is essential to fair dispute resolution, but from the State's perspective it is even more so, since the Rule of Law is one of the basis of the legitimacy of the State's authority. See Chapter 2.

${ }^{759}$ Cavanagh 862 (n 757).
} 


\section{a. Mutuality}

Fairness through the operation of preclusion is anchored in the idea that everyone should have his own day in court; ${ }^{760}$ this is one of the most basic requirements for preclusion to operate. To be bound by a judgment, a party has to be part of the litigation process; this is true both in common and in civil law systems.

In the U.S., the Supreme Court explained that 'in Anglo American jurisprudence [...] one is not bound by a judgment in personam in a litigation in which he is not designated as a party or to which he has not been made a party by service of process.'761

In the EU context, the right to a fair trial is enshrined both in the Charter of Fundamental Rights of the European Union, ${ }^{762}$ which since the Lisbon Treaty ${ }^{763}$ has the same value as the EU Treaties and in the European Convention on Human Rights. The Convention establishes that 'everyone is entitled to a fair and public hearing within a reasonable time by an independent and impartial tribunal established by law';764 this comprises the right of access to a court, even though this right can be limited. ${ }^{765}$ This is important because all the countries party to the Council of Europe are also party to the Convention, and soon the EU itself will accede to it, ${ }^{766}$ submitting to the jurisdiction of the European Court of Human Rights. Therefore, the idea of a fair trial, as developed both under the Charter and the Convention, becomes an important concept regarding the extent to which the mutuality principle may be weakened in the design of aggregate litigation procedures.

760 Richards v. Jefferson County, 517 U.S. 793, 803 (1996).

761 Ibid 798, citing Hansberry v Lee, 311 U.S. 32, 40 (1940).

762 Art 47.

763 TEU, art 6(1).

764 Art 6(1).

765 This is not an absolute right; the European Court of Human Rights will evaluate if the limitations pursue a legitimate aim, if there is a reasonable relationship of proportionality between the means employed and the aim sought to be achieved and if they do not restrict or reduce the access of the individual in a way that the very essence of his right is impaired. See Ashingdane v the United Kingdom (1985) Series A no 93, para 57; Tinnelly \& Sons Ltd and Others and McElduff and Others $v$ the United Kingdom ECHR 1998-IV, para 72.

766 TEU, art 6(2) mandates the EU to accede to the ECHR. 
The Brazilian Procedural Civil Code clearly states that a judicial decision on the merits creates res judicata for the parties in respect of whom it is issued, not benefiting or harming third parties. ${ }^{767}$ The same is true in the Spanish Act of Civil Procedure. ${ }^{768}$

By requiring that in order to be bound by a judgment, the parties are present at a legal proceeding, the law guarantees that both parties will be heard and will be able to present their case, engaging in a fair dispute in front of a judge. As it will be demonstrated, there are many instances in which this requirement has been relativized, especially in the United States.

\section{b. Identity of Causes of Action}

Generally, a cause of action can be understood as comprising the facts that are legally relevant and the legal reasons that give rise to a claim, both in common and civil law; however, both the theory and operation of causes of action is highly dependent on the individual legal system.

In the U.S. system, the concept of the cause of action has suffered a transformation, shifting from one based on theories of recovery to one based on transactions. Initially, a cause of action would have been substantiated on the legal theory that was used for recovery, and as such, it would have been possible to raise multiple lawsuits in respect of the same factual situation, based, for example, on torts for the first lawsuit and breach of contract in the second. A plaintiff could bring as many lawsuits as legal theories were applicable to a certain set of facts. ${ }^{769}$ After some time, the cause of action concept became more practical, not only admitting, but requiring that different theories of recovery be used in a single lawsuit when these theories are based on the same 'transaction' and set of proof at stake; ${ }^{770}$ parties would thus be precluded from using a new theory based on the same factual circumstances for another lawsuit. 771 Therefore, the element identity of

\footnotetext{
767 Art 472.

${ }^{768}$ Art 222.3: 'La cosa juzgada afectará a las partes del proceso en que se dicte [...]'.

769 Cavanagh 866-67 (n 757).

770 Ibid .

${ }^{771}$ See § 24.1, Restatement (Second) of Judgments (When a valid and final judgment rendered in an action extinguishes the plaintiff's claim pursuant to the rules of merger and bar, the claim extinguished includes
} 
causes of action', for claim preclusion purposes, is nowadays based on the factual proof for the theories of recovery; if the factual proof is the same, there is identity of the causes of action for claim preclusion purposes. ${ }^{772}$

The Brazilian system has a more limited view on the cause of action; any changes to the legally relevant facts also changes the cause of action for a lawsuit, therefore avoiding preclusion. ${ }^{773}$ The Spanish system, on the other hand, uses the concept of the actual and virtual object of civil procedure, enshrined in article 400.1 of the LEC, which states that 'when what is claimed in a lawsuit can be based in different facts or different legal theories or titles, all of them will be deemed pleaded at the time of the request, without their use being admissible in a later lawsuit'. ${ }^{774}$

Therefore, the definition of the cause of action and what causes of action a decision encompasses for preclusion purposes vary; this also has consequences on collective redress mechanisms. A more encompassing theory guarantees greater efficiency and protection to the defendant, while a less encompassing theory allows the claimant to sue over and over again for the same claim, on the basis of legal facts and theories that could have been used in the first procedure.

\section{c. Judgment on the Merits}

A judgment on the merits of the dispute is nothing more than a decision over the substantive portion of the claim made by the plaintiff. Generally, decisions that are not on the merits of the dispute, such as those related to lack of jurisdiction do not have

all rights of the plaintiff to remedies against the defendant with respect to all or any part of the transaction, or series of connected transactions, out of which the action arose).

772 Cavanagh 867 (n 757); Restatement (Second) of Judgments §24 (1982); See also O'Brien v. City of Syracuse, 429 N.E.2d 1158, 1159 (N.Y. 1981) ('once a claim is brought to a final conclusion, all other claims arising out of the same transaction or series of transactions are barred, even if based on different theories or if seeking a different remedy'); Farmers High Line Canal v. City of Golden, 975 P.2d 189, 203 (1999) (Furthermore, ' $\mathrm{t}]$ he best and most accurate test as to whether a former judgment is a bar in subsequent proceedings ... is whether the same evidence would sustain both, and if it would the two actions are the same, and this is true, although the two actions are different in form.' Pomponio v. Larsen, 80 Colo. 318, 321, (1926)).

773 See Marcus Vinicius Rios Gonçalves, Direito Processual Civil Esquematizado (Editora Saraiva 2012) 43940; Daniel Amorim Assumpção Neves, Manual de Direito Processual Civil (Metodo 2011) 541-42; Junior 427 (n 587).

774 See Andres de la Oliva Santos and Ignacio Diez-Picazo Gimenez, Derecho Procesal Civil: El Proceso de Declaracion (3 edn, Editorial Universitaria Ramon Areces 2004) 71-75. 
preclusion effects. ${ }^{775}$ There are exceptions, such as the issue preclusion in the United States and the request for res judicata in prejudicial questions in Brazil. 776

\section{d. Types and Scope of Preclusion}

The scope of preclusion delineates the matters that a judgment will cover and prohibits re-litigation. It is the last calibration element between the efficiency and fairness of the legal system, as it defines the aspects of the dispute that will be definitely solved. Here the difference between the common law and the civil law is considerable.

In the United States, preclusion can be separated in two groups, claim preclusion and issue preclusion.

The notion of claim preclusion can be dissected into the common law doctrines of bar and merger. When a plaintiff is successful in a lawsuit, the claim merges into the judgment and the plaintiff is then not allowed to pursue another lawsuit with the same claim. ${ }^{777}$ On the other hand, if plaintiff loses the litigation, his claim is extinguished and the judgment acts as a 'bar' to him. ${ }^{778}$ In practice this means that when the litigation comes to an end, the plaintiff is not allowed to start another lawsuit based on the same claim, whether the previous lawsuit was successful or not. The doctrine operates throughout the court systems of the United States, in the sense that a claim unsuccessfully pursued in a federal court may not be re-litigated in a state court. This is an important characteristic of the doctrine since the American legal system has a wide variety of court structures existing throughout the country, each of which might differ from the other due to the political design of the American state. 779

775 See Cavanagh 867 (n 757). Brazilian Civil Procedure Code, art 267 and 269; Spanish Act of Civil Procedure, art 222.2.

776 Brazilian Civil Procedure Code, art 470.

777 See Kasper Wire Works, Inc. v Leco Eng'g \& Mach., Inc., 575 F.2d 530, 535-36 (5 ${ }^{\text {th }}$ Cir. 1978) ('When the plaintiff obtains a judgment in his favor, his claim "merges" in the judgment; he may seek no further relief on that claim in a separate action').

${ }^{778}$ Id.: 'Conversely, when a judgment is rendered for a defendant, the plaintiff's claim is extinguished; the judgment then acts as a "bar".'

779 See Baker v General Motors Corp., 522 U.S. 222, 233 (1998) ('A final judgment in one State, if rendered by a court with adjudicatory authority over the subject matter and persons governed by the judgment, qualifies for recognition throughout the land. For claim and issue preclusion (res judicata) purposes, in other words, the judgment of the rendering State gains nationwide force.') 
Issue preclusion, on the other hand, is narrower than claim preclusion and prohibits only the re-litigation of 'an issue of fact or law necessary to [a court's] judgment'. 780 The issue will be barred from being discussed in another lawsuit based on different causes of action between the same parties.

In the European context, where there are many different legal systems operating and interacting with one another under EU law, res judicata has also been recognized as an important principle. ${ }^{781}$ Courts do not have to review a final decision adopted in breach of EU law unless, under their own national law, they have the power to do so. ${ }^{782}$ Generally, under the Brussels/Lugano Regime, the extension of the claim preclusion effect will be according to the rules of the country where the judgment was made, but this depends on the approach taken by each Member State. ${ }^{783}$

In the civil law countries under study, preclusion effects are deployed through their own doctrine of res judicata, ${ }^{784}$ which can be explained through two different aspects: the formal res judicata, having its effects within the legal procedure, i.e. internally, and the material res judicata, which extends the effects of the decision beyond the boundaries of the procedure.

The formal res judicata operates through the immutability of the decision within the process due to the impossibility of appeal, either because the law does not allow for such an appeal or because the party that had the right to appeal did not launch it in due time or decided not to appeal. ${ }^{785}$ It is an internal effect of judicial decisions, operating

780 See Kremer v Chem. Constr. Corp., 456 U.S. 461, 466 n.6 (1982).

781 ('[A]ttention should be drawn to the importance, both for the Community legal order and national legal systems, of the principle of res judicata. In order to ensure both stability of the law and legal relations and the sound administration of justice, it is important that judicial decisions which have become definitive after all rights of appeal have been exhausted or after expiry of the time limits provided for in that connection can no longer be called into question ((Case C-224/01 Köbler v Republik Österreich [2003] ECR I-10239, para 38)'), Case C-234/04 Rosmarie Kapferer v Schlank \& Schick GmbH [2006] ECR I-2585, para 20.

782 See Kapferer v Schlank (n 781), paragraph 24. On the arbitration context, see Case C-126/97 Eco Swiss China Time Ltd. v Benetton International NV [1999] ECR I-3055, para 48.

783 See Jacob van de Velden and Justine Stefanelli, The Effect in the European Community of Judgments in Civil and Commercial Matters: Recognition, Res Judicata and Abuse of Process (British Institute of International and Comparative Law 2008) 51-62.

784 'Coisa julgada' or 'cosa juzgada'.

785 Humberto Theodoro Júnior, Curso de Direito Processual Civil - teoria geral do direito processual civil e processo de conhecimento, vol 1 (Forense 2012) 558. 
within the procedure and binding the parties and the judge to its effects, imposing both a duty to decide according to the previous decision in the process and prohibiting the parties from asking for a measure that would deny the effects of such decision. ${ }^{786}$ The formal res judicata operates in respect of any decisions and is applicable at the moment when the possible appeals are exhausted, either through their use or by the lapse of time before which the appeal could have been launched. 'The formal res judicata is related not to the effects of the decision, but to the decision itself as an act of the procedure.'787

The material res judicata, on the other hand, 'is the immutability of the substantial effects of a decision on the merits' ${ }^{788}$ As a technical legal matter, the majority of Brazilian doctrine adopts the concept of material res judicata as relating to the quality of the judicial decision that makes its effects immutable. ${ }^{789}$

Res judicata operates therefore by precluding those affected by it from discussing the matter again following the conclusion of the process (formal res judicata) and immunizing any change to the effect of the decision, either through the same legal process or through another one (material res judicata).

As to the object of the lawsuit, res judicata operates differently in the Brazilian and the Spanish system. In Brazil, res judicata is more limited and operates only in respect of the dispositive part of the judgment; 790 it does not encompass its rationae decidendi concerning the necessary questions underpinning the outcome of the judgment, ${ }^{791}$ unless

\footnotetext{
${ }^{786}$ Juan Montero Aroca and others, Derecho Jurisdiccional II - Proceso Civil (Tirant Lo Blanch 2004) 468.

787 Candido Rangel Dinamarco, 'Relativizar a Coisa Julgada Material' (2001) 55/56 Revista da Procuradoria Geral do Estado de São Paulo 25, 7.
}

788 Ibid 6.

${ }^{789}$ See ibid ('Sendo um elemento imunizador dos efeitos que a sentença projecta para fora do processo e sobre a vida exterior dos litigantes, [a utilidade da coisa julgada] consiste em assegurar estabilidade a esses efeitos, impedindo que voltem a ser questionados depois de definitivamente estabelecidos por sentença não não (sic) mais sujeita a recurso'); Negi Calixto and Victor A. A. Bonfim Marins, 'Eficácia da Sentença e Coisa Julgada Perante Terceiros' (1989) 25 Revista da Faculdade de Direito da UFPR 93, 94.

790 This is the part of the judgment where the judge solves the questions being asked by the parties to the lawsuit. Brazilian Civil Procedure Code, art 458 III.

791 The exception to this would be if a contrary decision would put the dispositive part of the first decision in danger. See Neves 536-38 (n 773) (the example given in this book is the following: A sues B to perform a contract and B argues that the contract was invalid. The judge, based on this defense, decides that B does not have to perform the contract. Since B did not request the declaration of the invalidity of the contract, $\mathrm{A}$ could still sue for damages for non-compliance with the same contract). 
required by one of the parties. ${ }^{792}$ The Spanish system, on the other hand, operates differently as it extends the res judicata effects to the reasoning that underpins the outcome of the decision; it is thus closer to the U.S. system of preclusion. ${ }^{793}$

In respect of these characteristics of the operation of preclusion, the mutuality requirement is the most important with regard to the limits on the use of the opt-out procedure.

\section{b. Preclusion and Non-Mutual Parties: possibility for the opt-out procedure}

The starting point for the subjective limits of preclusion is the mutuality requirement, which is cornerstone of this institution. The mutuality requirement is justifiable because, as a matter of due process and fairness, parties that did not have an opportunity to present their case or to defend themselves should not be bound by a decision. As it is common with rules, for this particular one there also are exceptions, which vary widely depending on the relevant jurisdiction.

\section{a. United States}

In the United States, the exceptions to the mutuality requirement vary depending on the type of preclusion being discussed. There are six exceptions ${ }^{794}$ that can be reduced into 3 groups: the agreement of a non-party in being bound by a judgment to which it is not a party, a legal relationship between the party that was party to the previous judgment and the non-party suffering its preclusion effects, and finally, statutory schemes giving

792 Brazilian Civil Procedure Code, art 470.

793 The issue still is controversial, See Santos and Gimenez 554-57 (n 774).

794 1) 'A person who agrees to be bound by the determination of issues in an action between other is bound in accordance with the terms of his agreement', Restatement $2^{\text {nd }}$ of Judgments, $§ 40 ; 2$ ) pre-existing substantive legal relationships between the non-mutual party to be bound and the party to the judgment, such as in the assignor-assignee relationship, see Taylor v Sturgell 552 U.S. 880, 881 (2008); 3) Adequate representation may be sufficient to bind a non-party on certain limited circumstances, such as the class action, see Martin v Wilks, 490 U.S. 755, 762 (1989); 4) Assuming control over a litigation in which the judgment was rendered is also a way of being bound by the decision, see Montana v United States, 440 U.S. 147 (1979); 5) A lawsuit through proxy is also preclusive. In other words, a person who brings a lawsuit as an agent or representative of a party bound by a previous decision also suffers its preclusive effects, see Taylor v Sturgell 552 U.S. 880, 881 (2008); and 6) when a statutory scheme that does not violate due process is sufficient to 'foreclose successive litigation by nonlitigants, see Martin v Wilks, 490 U.S. 755, 762 (1989). 
preclusive effects in respect of non-parties to a judgment, ${ }^{795}$ as long as there are no due process violations.

In respect of issue preclusion, the discussion is slightly different. Even though parties who are not party to a judgment cannot be bound by it, the U.S. system allows strangers to a judgment to use the decision reached in it. ${ }^{796}$

Issue preclusion can be used both defensively and offensively. A defensive use of preclusion occurs when a party uses a previous decision to prevent a plaintiff who was present in a previous lawsuit from pursuing his claim. The recognition of its use in federal courts was made in the Blonder-Tongue Laboratories, Inc. v. University of Illinois Foundation case ${ }^{797}$, where the Supreme Court overruled the holding of Triplett v. Lowell798 'that a determination of patent invalidity is not res judicata against the patentee in subsequent litigation', ${ }^{799}$ allowing the defendant to use a prior determination in a judgment where only plaintiff was a party, against plaintiff himself. The rationale for the decision was that '[i]n any lawsuit where a defendant, because of the mutuality principle, is forced to present a complete defense on the merits to a claim which the plaintiff has fully litigated and lost in a prior action, there is an arguable misallocation of resources.' 800 Therefore, the question of allowing estoppel against a plaintiff would rest on the determination of whether the plaintiff had 'a full and fair opportunity to litigate' the issue. 801

The offensive use of preclusion for non-mutual parties is also possible, but it has more complications than its defensive counterpart. Parklane Hosiery Co. v. Shore ${ }^{802}$ was a stockholder's class action in which the claim was made that the corporation and its officers had issued false and misleading statements in violation of the Federal Securities

\footnotetext{
795 This is the case of the class action.

796 Cavanagh 869 (n 757).

797402 U.S. 313 (1971).

798297 U.S. 638 (1936).

799402 U.S. 313 (1971).

800402 U.S. 313, 329 (1971).

801 Ibid.

802439 U.S. 322 (1979).
} 
Act. While the class action was ongoing, the SEC brought suit against the same defendants regarding the same issue of facts, and after a non-jury trial, the case was decided in favor of the SEC. The plaintiffs in the stockholder's action moved for summary judgment arguing collateral estoppel on the issues that has already been decided in the SEC suit; this argument was denied by the District Court and reversed by the Court of Appeals, finally being affirmed by the Supreme Court. 803 The general rule established in the case was that 'in cases where a plaintiff could easily have joined in the earlier action or where, either for the reasons discussed above or for other reasons, the application of offensive estoppel would be unfair to a defendant, a trial judge should not allow the use of offensive collateral estoppel.'804 The textbook example of unfairness in collateral estoppel is the case where the defendant is sued for a small amount of money and does not have an incentive to defend himself vigorously and as such, loses the case; thereafter, other plaintiffs linked to the same set of facts try to sue the defendant for millions of dollars and use collateral estoppel in respect of the decision in the first case. ${ }^{805}$

\section{b. General Exceptions in Civil Law: Brazil and Spain}

The Brazilian Civil Procedure Code clearly states that a judicial decision on the merits creates res judicata for the parties in respect of whom it is issued, neither benefiting nor harming third parties. ${ }^{806}$ The same is true for the Spanish Act of Civil Procedure. ${ }^{807}$ Mutuality is so important that it is a constitutional guarantee..$^{808}$

In Brazil, the exceptions are very specific and are related to cases where the thirdparty res judicata effect is necessary or follows from the decision itself; this is the case, for example, in matters concerning the mental state of the person. Even though there is a third-party effect, there are guarantees in place for protection. The binding effect of the

\footnotetext{
${ }^{803}$ See Parklane Hosiery Co. v. Shore (n 802).

804 Parklane Hosiery Co. v. Shore (n 802) 331.

805 E.g. Berner v. British Commonwealth Pac. Airlines, 346 F.2d 532 (2 ${ }^{\text {nd }}$ Cir. 1965).

806 Art 472.

${ }^{807}$ Art 222.3: 'La cosa juzgada afectará a las partes del proceso en que se dicte [...]'.

${ }^{808}$ Art. 5, LV of the Brazilian Constitution guarantees litigants the right to answer (contraditório) and the right to a full defense. An article that provides a similar guarantee in the Spanish Constitution is article 24.1 ('Todas las personas tienen derecho a obtener la tutela efectiva de los jueces y tribunales en el ejercicio de sus derechos e intereses legítimos, sin que, en ningún caso, pueda producirse indefensión').
} 
decision will only operate if all those who might have an interest in the lawsuit are served with process. ${ }^{809}$

In Spain, res judicata also affects successors in title and heirs, as well as those who are entitled to the right that constitutes the basis legitimating one of the parties to the lawsuit. 810 The third-party effect in the Spanish system, concerning the successors and heirs, only operates if the acquisition title was formed after the lawsuit regarding the object of dispute was initiated. ${ }^{811}$ In this sense, the system is designed simply to protect the party in a lawsuit from an unfair disposition of the defendant's assets; it does not raise any greater problem of due process since the parties involved in the transaction should be aware of this peculiarity of the Spanish legal system. The second case of the application of res judicata to third parties arises where the condition of the person constitutes the legal question of the subject of the procedure. The operation of res judicata and the erga omnes effect of the decision is a necessary precondition for the effectiveness of decision. For example, a person who is judged incompetent for civil acts and the consequent change in legal status derived from the decision, has to be opposable to everyone, and not only in respect of the parties to the lawsuit. The erga omnes effect occurs only after the registration of the change of status in the Civil Registry, giving constructive legal notice about the status of the person to everyone. ${ }^{812}$

Mutuality therefore is a strong principle in civil law systems, to the extent that the development of a full-blown opt-out aggregate litigation procedure might be highly unlikely in such systems; nevertheless, alternatives have been created in respect of mass procedures, in particular, within the consumer context.

\footnotetext{
${ }^{809}$ Brazilian Civil Procedure Code, art 472.

810 Spanish Act of Civil Procedure, art 222.3. This provision points to article 11 of the same legal text, which establish the use of some forms of class actions for consumer disputes within the Spanish legal system.

811 Aroca and others 479 (n 786).

812 Spanish Act of Civil Procedure, Art. 222.3.
} 
c. The Operation of Preclusion in Representative Actions: how the mutuality requirement is circumvented in Brazil and Spain

A special topic in both Brazil and Spain is preclusion in collective litigation. As mutuality has a constitutional status, the design of collective means of redress and their effects on third parties, is more limited than in the United States.

Despite this seemingly insurmountable obstacle, the Brazilian and Spanish legal systems have designed and deployed collective means of redress for some specific situations, with the most important having been developed in the consumer context; for these purposes, a workaround had to be made with regard to the operation of res judicata.

The problem can be framed in the following way: as a matter of constitutional law and due process guarantees, a person cannot be bound by a lawsuit without being able to participate in it; as such, the question arises as to how a collective means of redress can be designed without including every possible party in the procedure?

The answer to this question and the workaround developed can be explained through the categories of collective rights created, those which have been legitimated to pursue collective actions and the mitigated effects of res judicata in these situations.

In Brazil, there are basically three categories of collective rights: diffuse rights, collective rights and individual homogeneous rights. ${ }^{813}$ Diffuse rights are transindividual and indivisible rights belonging to a group of unidentified people; collective rights are also transindividual and indivisible, but the group to which they belong can be identified; finally, individual homogenous rights belong to individuals and are divisible, albeit having a common origin. 814

The persons authorized to launch a collective action are highly limited, even in cases of individual homogenous rights; most of the legal entities authorized to bring such an action are public. ${ }^{815}$ In fact, the only private entity category that could pursue a lawsuit

\footnotetext{
${ }^{813}$ For an overview of the topic, see Fredie Didier Jr and Hermes Zaneti Jr, Curso de Direito Processual Civil: Processo Coletivo, vol 4 (Editora Podivm 2011) 75-98.

814 Brazilian Consumer Defense Code, art 81. See ibid .

815 Prosecutor's office, political entities (Union, States and Municipalities) and entities from the public administration. Brazilian Consumer Defense Code, art. 82, I, II and III.
} 
for collective redress are associations that have been constituted for at least one year and that include within their objectives the defense of interests and rights of consumers; ${ }^{816}$ this would also give a public spin to its operation.

These entities are authorized to go before a court and engage in a lawsuit against a company that has violated the rights of a multitude of people, without the need for their participation in the lawsuit. As a logical matter, within the Brazilian legal system, while the res judicata cannot bind those who were not party to the lawsuit, at least to the extent that it might be prejudicial to them, it will operate against the defendant. Due to this particularity there are a few different ways as to how the res judicata will operate; this will depend on the class of rights being discussed.

Due to the nature of the diffuse types of rights, which are transindivindual, indivisible and belonging to an unidentified group of people, the res judicata will be erga omnes, 817 unless the claim for relief is denied due to lack of evidence. ${ }^{818}$ Both those legitimized to pursue the lawsuit and the defendant will not be able to discuss the same matter again. In respect of the collective type, the effect is ultra partes, encompassing the members of the group that has been harmed. ${ }^{819}$ To clarify, it is important to underline that the rights in question for these kinds of actions are those with a transindividual character, and not the individual rights of the persons who were harmed due to the transgression of a transindividual right. For example, in air pollution cases, the group of persons living close to a factory have a right to clean air, but the harm that they may suffer due to air pollution is an individual right, which is not encompassed by the concept of collective rights lato sensu. 820 Therefore, a decision against the individuals in these lawsuits does not preclude them from proceeding with their own claims arising out of the same factual circumstances. ${ }^{821}$

\footnotetext{
${ }^{816}$ Brazilian Consumer Defense Code, art 82, IV.

817 Binding everyone.

818 Brazilian Consumer Defense Code, art 103, I; Law 7.347/1985, art 16.

819 Brazilian Consumer Defense Code, art 103, II.

820 Diffuse and collective rights.

821 The law is clear on this point - see Brazilian Consumer Defense Code, art $103 \S 1$.
} 
In respect of the individual homogenous rights collective lawsuit, the res judicata is secundum eventum litis, in other words, its effect depends on its outcome. If the claim for relief is accepted, the effect of the res judicata is erga omnes, and thereafter, any of the individuals may execute the decision individually. On the other hand, if the claims are dismissed, even with prejudice, the individuals who have not assisted in the lawsuit may file another lawsuit for damages on an individual basis. ${ }^{822}$ One detail to be considered is that if the lawsuit is dismissed with prejudice, the res judicata operates in respect of those who are legitimized to propose a collective lawsuit on the matter, therefore precluding them from starting a new collective lawsuit on the basis of the same questions. ${ }^{823}$ This system protects the individuals from being bound by a decision against them when they were not able to participate and defend their rights, while at the same time, it is an effective mechanism to solve mass disputes in the case that the decision is favorable to the plaintiffs.

Therefore, in Brazil, even though preclusion has a strong connection to the concept of mutuality, there are some exceptions that allow for third-party effects in respect of those who have not participated in the proceedings; this never operates to their detriment.

In Spain, the practical effect of representative litigation in the consumer context is similar to the Brazilian scheme. A group that consists of more than half of the harmed, in the case that identity can be easily ascertained, are allowed to choose a person to represent them in the lawsuit. ${ }^{824}$ Consumer associations are also legitimized to represent consumers. ${ }^{825}$ The decision in these cases has to provide an identification of those who will benefit from the lawsuit; when the individualized determination is not possible, the characteristics and requirements to demand payment have to be made clear, ${ }^{826}$ so the individual consumers can execute the decision afterwards. ${ }^{827}$ Also, if the decision declares a certain type of behavior illegal, it must also declare if there will be effects on those who

\footnotetext{
822 Brazilian Consumer Defense Code, art $103 \S 2$.

${ }^{823}$ International Commercial Arbitration Committee ILA, 'Interim Report: "res judicata" and Arbitration' (Berlin Conference) 19.

${ }^{824}$ Spanish Act of Civil Procedure, art 6.7, 7.7 and 11.2.

825 Spanish Act of Civil Procedure, art 11.

${ }^{826}$ Spanish Act of Civil Procedure, art 221.1.1.

827 Spanish Act of Civil Procedure, art 519.
} 
have not been a party to the lawsuit. ${ }^{828}$ Since these representative actions may have an effect on those who have not been party to the lawsuit, the Spanish system demands that notice is given either through every individual consumer when they are easily identifiable 829 or through communication channels that cover the territory where those who have been harmed may be found. ${ }^{830}$ To this extent, the system is similar to the Brazilian one, as the court may only bind absent consumers if the decision is one that concerns the illegality of a certain type of behavior by those causing harm.

\section{c. Preclusion in arbitration: what law will govern its operation?}

The analysis of preclusion in arbitration should begin firstly at the national level. In most jurisdictions, the arbitral award will have the same preclusive effects as a judgment of a national court. 831 Within the national context, preclusion in arbitration is no more problematic than preclusion from legal decisions; as long as the award comprises the necessary requirements, it will have the effects of a judicial decision in the national jurisdiction.

The complexity of the question increases when the object of analysis is transposed to the transnational realm, as the clarity of what kind of preclusion will be applicable fades. When the dispute is transnational and arbitral awards become international, the legal infrastructure regulating them reflects such change through the applicability of the international treaties on the matter. Article III of the New York Convention provides that '[e]ach Contracting State shall recognize arbitral awards as binding', implicitly imposing some kind of preclusion effects on the award, even though it does not provide any clear cut rule on how preclusion should be operational. This 'binding' quality of an arbitral award attributed by Article III of the New York Convention is a 'constitutional statement of principle' 832 that 'impl[ies] at least equally broad principles of preclusion as those

\footnotetext{
${ }^{828}$ Spanish Act of Civil Procedure, art 221.1.2.

${ }^{829}$ Spanish Act of Civil Procedure, art 15.2.

830 Spanish Act of Civil Procedure, art 15.1.

${ }^{831}$ For an analysis of the difference between judicially confirmed and unconfirmed awards in the U.S., see Born 2895-904 (n 516); Brazilian Arbitration Law, art. 31; Spanish Arbitration Act, art. 43.

832 Ibid 2892.
} 
applicable to national courts judgments'. ${ }^{83}$ Since the preclusion rules vary from jurisdiction to jurisdiction, the problem that is to be solved concerns the preclusion rule that will be applicable in a given case.

At least four possibilities are available: (a) the law of the jurisdiction where the new lawsuit is brought; (b) the law of the arbitral seat; (c) the law applicable to the arbitration agreement or to the merits of the dispute; and finally (d) international preclusion rules. ${ }^{834}$

Each of these possibilities has its own rationale for its applicability. The idea that res judicata is a procedural defense, therefore belonging to the court of the second lawsuit, would lead to the applicability of the law in the jurisdiction where the second lawsuit is brought. 835 On the other hand, the procedural aspect of res judicata could also be used to sustain the position that the applicable law for preclusion should be the law of the place where the award was rendered.836 Since arbitration agreements are creatures of consent, the substantive applicable law approach to define the res judicata effects of an arbitral award is also justifiable. ${ }^{837}$ Finally, the international preclusion rules approach is defended by Gary Born;838 the idea that preclusion effects are, in a substantial manner, private rights derived from the arbitration agreement between the parties, Gary Born advances that international preclusion principles derived from the New York Convention and from the international arbitral process should be applicable, instead of a national preclusion rule. 839

There is no single correct solution to this question; pragmatically, both the law of the arbitral seat and the law of the enforcing forum are highly important when discussing the preclusive effects of an arbitral award. In any event, at a minimum, arbitral awards

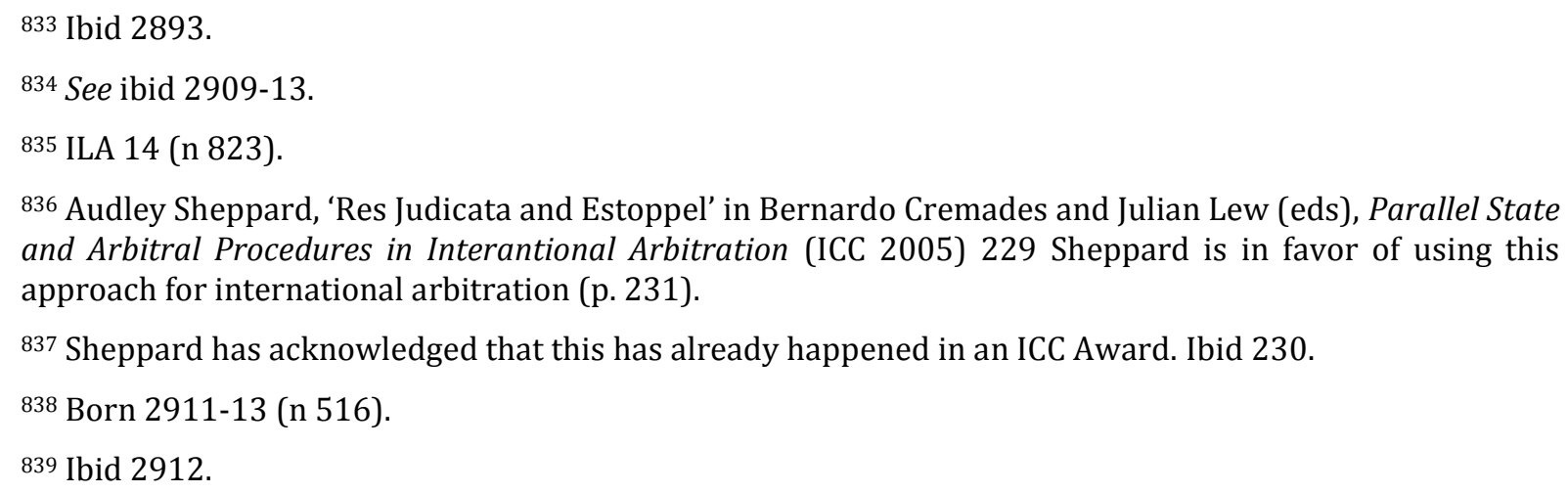
and Arbitral Procedures in Interantional Arbitration (ICC 2005) 229 Sheppard is in favor of using this approach for international arbitration (p. 231).

837 Sheppard has acknowledged that this has already happened in an ICC Award. Ibid 230.

838 Born 2911-13 (n 516).

839 Ibid 2912. 
will have preclusive effects that encompass, at least, the dispositive part of the decision, generating what is known in the U.S. system as claim preclusion. These international arbitral awards do have to be confirmed in order to have preclusion effects, ${ }^{840}$ but once they have been confirmed, they have the same preclusive force as national court decisions. ${ }^{841}$ In the U.S., the reach of the preclusion effects of an arbitral award is broader since issue preclusion also operates, ${ }^{842}$ even though its third-party effect is more limited than in U.S. court decisions. ${ }^{843}$

As the type of preclusion and its extension are important to legal certainty, the question becomes an important one that has to be considered when designing an aggregate mechanism for dispute resolution based on arbitration.

\section{Final Considerations on Aggregate Litigation Design}

Aggregate litigation functions as a mechanism both to enable compensation and to guarantee the application of the law. ${ }^{844}$ The design of an aggregate litigation system has to consider the conflicts of interest that arise out of the different classes of claimants in the same legal procedure, the conflicts with legal counsel and the conflicts with thirdparty financiers, if they will be a part of the system.

In addition, the design must engage the limitations of the legal system in which the aggregate mechanism has to be applicable. As constraints of both an ethical and procedural nature, and sometimes tied to constitutional principles, they may limit the range of options that are available. Procedural constraints on preclusion become an especially important topic when the dispute is transposed to the transnational realm. ${ }^{845}$

\footnotetext{
840 Unconfirmed awards in the United States do not have the full faith and credit of a judicial judgment as a statutory matter, but nonetheless they do have comparable preclusive effects developed under the jurisprudence of U.S. courts. Ibid 2896-98.

841 In the U.S., see Lewis v. Circuit City Stores, Inc., 500 F.3d 1140, 1147 (10 th Cir. 2007).

842 For exceptions on the application of preclusion, see Born 2900 (n 516).

843 Ibid 2901

844 See Layton 93-96 (n 700).

845 The transnational problems will be addressed more extensively in Chapter X.
} 


\section{Aggregate Dispute Resolution and Securities Disputes}

Throughout this chapter, it has been established that one of the purposes of aggregate litigation is to provide economies of scale to facilitate litigation that otherwise would not be initiated due to the costs or low value of the claims at stake, in addition to facilitating the management of claims by courts and ensuring the application of the law. Aggregate litigation, therefore, is a manner of pursuing redress in respect of claims that otherwise would not be litigated, thus providing access to justice.

Aggregate dispute resolution design has to consider the incentives of the parties who will be part of the process; at the same time, it is important that in such design, consideration is made of the ethical and procedural limits relevant in specific jurisdictions. As a result of the different approaches of different legal systems, a one-size-fits-all solution may not be achievable. ${ }^{846}$ In any event, it is important to understand those situations in which aggregate litigation can be used with securities disputes. As shown in a previous chapter, in the securities context, there are three main different types of disputes: 1) investor v. issuer, 2) investor v. financial intermediary ${ }^{847}$ and 3) investor v. informational intermediary. ${ }^{848}$

Each of these disputes has their intrinsic characteristics, and some can benefit much more from an aggregate litigation approach than others. Aggregate litigation is only adequate where there are similar issues between the members of the group; otherwise, the management of such a procedure would become impossible. In the securities context, disputes that have this characteristic are those that involve one act which has consequences for a multitude of persons, such as a false or misleading statement made by an issuer or the issuing of a credit rating made with minimum regard for the fundamentals of the investment. In these cases, disputes concerning both the falsity of the statement and the lack of fundamentals of a rating would greatly benefit by being resolved in an aggregate manner, since the question would be applicable to all those that were harmed

\footnotetext{
${ }^{846}$ A proposal will be developed in the last chapter.

${ }^{847}$ Financial intermediaries are the banks, brokers and dealers that sell securities to the investor.

848 Informational intermediaries are those who provide information to the market or directly to the clients, such as credit rating agencies and auditing firms.
} 
by the statement or the rating. ${ }^{849}$ This is most likely to occur in relation to investor-issuer and investor and informational-intermediary disputes.

The other type of disputes - investor-financial intermediary - is unlikely to benefit from an aggregate procedure. The transaction between an investor and a financial intermediary is highly personal; the duties of the financial intermediary, such the duty to assess the suitability of the investment, is so linked to the personal characteristics of the investor that it would be highly unlikely that an aggregate procedure would provide any benefit, even if the practice creating harm has been engaged on a widespread basis.

Another consideration arising is that aggregate litigation procedures are national, are tied to specific jurisdictions and thus lack a very strong transnational appeal. Class or aggregate arbitration could be a possible solution to transnationalize aggregate dispute resolution solutions.

In respect of the disputes discussed previously, the likelihood of creating a class arbitration system is higher from the first to the last type of dispute due to their intrinsic characteristics. The first relationship arises out of the purchase or sale of a security, the most common types of which are shares of a company. Even though the harm has to arise out of a purchase or sale of securities, the link tying the buyer or holder to the company issuing the fraudulent statement is based on the shareholder/company legal relationship. To this extent, an arbitration agreement with a class arbitration provision could be inserted into the corporate charters of companies, which would bind all those who have a claim arising out of the shareholder relationship, even if it is based on the violation of securities law. In addition, the class aspect is stronger than in the other two types of dispute because there is an aspect to the company/shareholder relationship that is absent in those disputes, namely the fact that every single shareholder has something in common with the others, i.e. the company. They are partners of the enterprise that they are suing, and to this extent, they could be considered as a class or as members of a group. ${ }^{850}$

${ }^{849}$ Causation and individual damages may have to be litigated individually; nonetheless, the question of whether the information was false or the rating had no fundamentals to back it up still is a common issue for the class.

${ }^{850}$ Depending on when the securities were bought, different shareholders might have different interests according to the misleading statements that were made and the answers that the market gave to such 
The second set of disputes is the one in which investors sue the intermediaries buying or selling securities from them. The basis for arbitration would be the contractual agreement between investor and intermediary, and here the consumerist aspect of the relationship is much more relevant than in the previous case, which may prevent the use of arbitration in some countries. ${ }^{851}$ Even if arbitration is allowed, the use of class arbitration still encounters other barriers. While the use of contracts of adhesion might be common, creating a single legal matrix for the disputes with different costumers, the relationships are mainly bilateral, and as mentioned above, the class aspect that is present in shareholders/company relationships is missing in this type of dispute. It is also highly unlikely that intermediaries would include a class arbitration clause in their contracts and set up a mass arbitration system so their customers could pursue their claims collectively, since a piecemeal approach to litigation would most likely reduce their costs in dispute settlement due to the transaction costs faced by single plaintiffs bringing arbitration claims against them.

Finally, the last type of dispute would involve investors against informational intermediaries, where the latter have provided false or misleading information to the market. Even though a system of aggregate litigation would be beneficial in this case, the possibility of class arbitration is even lower than in the other two types of disputes. There would be no legal basis to confer jurisdiction to an arbitral tribunal since there are no direct legal relationships between investors and the possible defendants; all of the links would have to go through the company. One way to allow for arbitration in these cases would be through the contractual arrangement between the company and the rating agencies and auditors, or through statutory provisions that could require that these kinds of disputes have to be arbitrated. In any event, strong public support for the arbitration system would be necessary for this to work.

A first look at this question would then lead to a conclusion that class arbitration in the securities area outside the United States would only be viable in cases of securities

misstatements; in any event they have a link, namely of being 'partners' in an enterprise, one which is not present in the other types of disputes.

${ }^{851}$ For example, arbitration is forbidden in consumer relationships in Brazil. Consumer Defense Code, art. 51 VII. 
fraud where the company charter provides for class arbitration. Of course, the use of this mechanism is dependent on the inclusion of clear arbitration agreements in company charters allowing for class arbitration and the structuring a system that would not deny due process to the plaintiffs, since the question of notice might be an issue that should be considered to guarantee the effectiveness of the arbitral award. Therefore, outside jurisdictions that admit U.S. style class actions and class arbitration, the only possibility for this mechanism would be one arising within the context of issuer-investor disputes, assuming that this would be an acceptable arrangement under the public policy of the jurisdiction in which the award would have to be enforced.

Having established in this chapter that there are some types of securities disputes that may profit from an aggregate dispute resolution approach, in the next chapter I will give some examples of aggregate litigation mechanisms that currently exist, and then present more coherently the transnational questions which will subsequently be combined with those presented herein, in order to propose a model for transnational dispute resolution for securities transactions in the last chapter. 


\section{Chapter IX - Aggregate Litigation Models}

The objective of this chapter is to illustrate some of the different Aggregate Litigation models that are available today. Broadly there are three different models of aggregate litigation: (a) the first is the joinder of the parties in a single lawsuit, where individuals participate and have standing in the legal procedure; (b) the second is the use of test cases, where even though each individual claimant still has standing and participates in the procedure, some cases are used to determine general common issues for those involved in the litigation; (c) finally, the last mechanism is where a representative has the legal standing for a group of people, who will be bound by the decision even though they have not participated in the procedure. This chapter provides a brief overview of the American class action, representative actions, the Dutch Act on Collective Settlement of Mass Damages, the English Group Litigation Order, the German Capital Market Model Claims Act and class arbitration.

\section{The American Class Action}

Conceptually, the American class action is a mechanism where one or a few persons represent a whole group with similar characteristics in a lawsuit; all of those sharing these characteristics are bound by the decision, even if they are not active participants in the lawsuit.

\section{A. A Brief History of the Class Action}

Historical records show that while the class action has roots dating back as far as the $12^{\text {th }}$ century, ${ }^{852}$ it became a more commonly used mechanism only later in the $17^{\text {th }}$ century. At this point in time, group litigation, both in England and the US, was used mostly to regulate relationships within social groups. ${ }^{853}$

\footnotetext{
852 The earliest case found by Professor Yeazell, who wrote extensively on the subject, is Martin, Rector of Barkway v. Parishioners of Nuthamstead, from 1199. See Stephen C. Yeazell, 'The Past and Future of Defendant and Settlement Classes in Collective Litigation' (1997) 39 Arizona Law Review 687-704, 688.

853 The social structure at that time was different than that which exists today, and so was the role performed by the judiciary. Aggregate litigation was the means through which a given social group,
} 
Contrary to the modern American class action, aggregate litigation in the $17^{\text {th }}$ century required the consent of all members of the class, a requirement that was easily achievable due to the social structure in place at the time. ${ }^{854}$ The decisions achieved had less of an all-or-nothing character and more of a regulatory one, where the judicial system would perform a legislative function with the decree executed serving as the basis for a change in the substantive law governing the relationship between the parties. ${ }^{855}$

In 1842, in the United States, Equity Rule 48 started governing group litigation in federal courts, even though it still was a mechanism that did not bind absent parties. ${ }^{856}$ Despite this rule, eleven years later, in Smith v. Swormstedt, 857 the U.S. Supreme Court stated that:

[W] here the parties interested are numerous, and the suit is for an object common to them all, some of the body may maintain a bill on behalf of themselves and of the others; and a bill may also be maintained against a portion of a numerous body of defendants, representing a common interest. 858

considered as a whole, would claim or resist claims from its direct administrative unit. Aggregate litigation therefore was a matter of status, and not of economic efficiency: not only did every single member of the group had identical rights to one another, since the relationship they had with their superiors was the same, but they were also organized as a political group, with institutions in place and communication channels with the manorial proprietor or the parishioner against whom they usually had to litigate. See Stephen C. Yeazell, 'Group Litigation and Social Context: Toward a History of the Class Action' (1977) 77 Columbia Law Review 866-96, 867, 77 Geoffrey C. Hazard, John L. Gedid and Stephen Sowle, 'An Historical Analysis of the Binding Effect of Class Suits' (1998) 146 University of Pennsylvania Law Review 1849, 1865.

854 Groups were small and cohesive. Yeazell, 'Group Litigation and Social Context: Toward a History of the Class Action' 878 (n 853).

855 Ibid 882; 84 One of the first reported cases where the contours of aggregate litigation started moving towards the class action as seen today was Brown v. Vermuden (22 Eng. Rep. 796 (Ch. 1676), a case from 1676, where a miner who had not been a part of previous proceedings was contesting the effects that they could have with regard to him. The court rejected the miner's claim based on the argument that, in the case that the court would not bind similarly-situated parties, suits of such a nature would be impossible to finally come to an end.

${ }^{856}$ See FED. R. EQ. 48 (1842) (repealed 1912), quoted in 42 U.S. (1 How.) lvi (1843) in Debra Lyn Bassett, 'Constructing Class Action Reality' 2006 Brigham Young University Law Review 1415, 1433 ('Where the parties on either side are very numerous, and cannot, without manifest inconvenience and oppressive delays in the suit, be all brought before it, the court in its discretion may dispense with making all of them parties, and may proceed in the suit, having sufficient parties before it to represent all the adverse interests of the plaintiffs and defendants in the suit properly before it. But in such cases the decree shall be without prejudice to the rights and claims of all the absent parties.')

85757 U.S. 288.

${ }^{858}$ Id at 301. 
The Supreme Court, with the language engaged in this decision, effectively established the possibility of binding effects of class actions on absent class members, which in fact created a contradiction with Equity Rule $48^{859}$ and generated important practical effects. From the date of this judgment until the revision of the Equity Rules, there were not only federal decisions binding absent class members based on Smith $v$. Swormstedt but also decisions based on Equity Rule 48 preserving the right of absent class members to sue, thus creating legal uncertainty. 860 In 1912 , the equity rules were revised, Equity Rule 48 was repealed and the procedure to deal with aggregate litigation was incorporated into Equity Rule 38.861 This Rule did not explicitly state that class actions could be binding on absent class members, but in 1921 this became clear under this new framework shaped by the Supreme Court decision of Supreme Tribe of Ben-Hur v. Cauble. 862

The next development of the American class action came with the Federal Rules of Civil Procedure. In 1934, the U.S. Congress passed the Rules Enabling Act ${ }^{863}$ giving the Supreme Court the 'power to prescribe general rules of practice and procedure and rules of evidence for cases in the United States district courts', which was duly exercised in 1938 with the promulgation of the Federal Rules of Civil Procedure. Rule 23 provided for class actions, allowing for 'persons constituting a class [...] so numerous as to make it impracticable to bring them all before the court' 864 to sue or be sued on behalf of all, as long as the character of the right was joint or common, as long as the adjudication of claims forming the object of the action could affect a specific property involved in the

${ }^{859}$ Hazard, Gedid and Sowle 1901-02 (n 853).

860 See ibid 1902-09.

861 Which provided that ' $[\mathrm{w}]$ hen the question is one of common or general interest to many persons constituting a class so numerous as to make it impracticable to bring them all before the court, one or more may sue or defend for the whole', containing therefore both the 'aggregate' and 'representative' characteristics of the modern class action. John G. Harkins, Jr., Federal Rule 23-The Early Years, 39 ARIZ. L. REV. 705, 705 (1997) citing JAMES LOVE HOPKINS, THE NEW FEDERAL EQUITY RULES 231 (1930). On the aggregate and representative characteristics of the class action see Bassett 1418-31 (n 856).

862 ('if the federal courts are to have the jurisdiction in class suits to which are obviously entitled, the decree when rendered must bind all of the class properly represented') 255 U.S. 356 (1921) 367.

${ }^{863}$ Current version at 28 U.S.C. § 2072 (2014).

864 The text of the 1938 Rule 23 is available at 39 Federal Rules Decisions 69. 
action or as long there was a common question of law or facts and a common relief was sought. 865

Even though the 1938 Rule 23 was prima facie clear, it raised a lot of different problems, including, amongst others, the proper labeling of a class action, the effects arising from it, 866 the extent of the judgments in class actions and the lack of binding effect of a 'spurious' class action on non-party class members. ${ }^{867}$ In 1966 , with the revision of the Federal Rules of Civil Procedure, Rule 23 was significantly altered, ${ }^{868}$ bringing it to its current design.

\section{B. Types of Class Actions and its Prerequisites}

Under the current Rule 23 of the Federal Rules of Civil Procedure, the basic prerequisites of a class action are numerosity, ${ }^{869}$ commonality, ${ }^{870}$ typicality ${ }^{871}$ and adequate representation. ${ }^{872}$

The first requirement, numerosity, is concerned more with the impracticability of joinder of all members of the class than with the actual quantity of members; it is not a highly contested issue..$^{873}$

The commonality and typicality requirements are the parameters in place for the efficiency of the class action and the protection of interests of class members. As stated in

865 These are the 'true', 'hybrid' and 'spurious' characters of the class action under the former Rule 23. See Bassett 1434-36 (n 856).

${ }^{866}$ Tom Ford, 'The History and Development of Old Rule 23 and the Development of Amended Rule 23' (1966) 32 Antitrust Law Journal 254, 257.

${ }^{867}$ For other issues that the former Rule 23 created, see the Advisory Committee's Notes on 39 Federal Rules Decisions 69.

86839 Federal Rules Decisions 69.

869 'the class is so numerous that joinder of all member is impracticable'. Federal Rules of Civil Procedure, $s$ 23(a)(1).

870 'there are questions of law or fact common to the class'. Federal Rules of Civil Procedure, s 23(a)(2).

871 'the claims or defences of the representative parties are typical of the claims or defences of the class'. Federal Rules of Civil Procedure, s 23(a)(3).

872 'the representative parties will fairly and adequately protect the interests of the class' Federal Rules of Civil Procedure, s 23(a)(4).

${ }^{873}$ Richard Nagareda, The Law of Class Actions and Other Aggregate Litigation (Foundation Press 2009) 67. 
General Telephone Co. v. Falcon, 874 they 'serve as guideposts for determining whether under the particular circumstances maintenance of a class action is economical and whether the named plaintiff's claim and the class claims are so interrelated that the interests of the class members will be fairly and adequately protected in their absence.' While commonality concerns the relationship of the class members to one another, typicality is a matter of the relationship of the class representative with the absent members of the class. 875

Adequate representation was a prerequisite even before the enactment of Rule 23. In Hansberry v. Lee 876 the petitioners, who were African-American, had bought a piece of real estate property and were sued on the basis of an alleged contractual stipulation between 500 property owners that those owners could not sell the properties to AfricanAmerican people. To be effective, the agreement had to be signed by $95 \%$ of the property owners, which had not in fact happened; 877 this issue of fact had been decided as if the signatures had been made in a previous case to which petitioners had not been a party. ${ }^{878}$ The Circuit Court found that the fulfillment of the condition precedent to the agreement was res judicata, a decision that the Supreme Court of Illinois affirmed. The question was whether the petitioners were bound by the previous judgment despite the fact that they were neither a part of it nor a successor in interest or in privity with the other parties to the suit. On constitutional grounds, it was a question of due process under the Fourteenth Amendment. Not only was the prior case one exclusively against the defendants, thus not having a class character, but also nor was it clear that 'the interest in defeating the contract outweighed their interest in establishing its validity'. ${ }^{879}$ The U.S. Supreme Court held that in this situation neither the defendants nor the plaintiffs had assumed the power to represent the petitioner in the previous case, and also that, due to their dual interests,

874457 U.S. 147 (1982).

875 Nagareda 73-74 (n 873).

876311 U.S. 32 (1940).

${ }^{877}$ As established by the proceedings of the lower courts that led to this decision. See 372 Ill. 369 , 24 N.E.2d 37.

878 Burke v Kleiman, 277 Ill.App.519 (1934).

${ }^{879}$ Hansberry v Lee (n 876). 
this representation was a responsibility that they could not discharge, reversing the lower court judgment.

If these four prerequisites are satisfied, a class action can be entertained in four different situations: 1) when there is a risk of inconsistent adjudication creating incompatible standards of conduct for the party opposing the class; 880 2) when adjudications regarding individual class members would be dispositive or affect the interests of other members not party to the adjudication; ${ }^{881} 3$ ) when 'the party opposing the class has acted or refused to act on grounds that apply generally to the class, so that final injunctive relief or corresponding declaratory relief is appropriate respecting the class as a whole'; 882 and finally, 4) when there are questions of law or fact common to class members that predominate over any questions affecting only individual members and the class action is a superior method of adjudication. 883

The three first types of class action contained in Fed. R. C. Proc. 23 (b)(1) and (2) are mandatory, meaning that the members of the class do not have the right to opt-out.884 The last one, based on the predominance of common questions over individual ones, do provide for the right to opt-out, but the class-wide preclusion effect is dependent on discharging the duty of providing the 'best notice that is practicable under the circumstances, including individual notice to all members who can be identified through reasonable effort'. 885

\section{Class Certification}

Certification is the procedural step by which the lawsuit is stamped with the class action seal, unleashing the legal consequences arising out from the case falling within category. The court has to certify the class '[a]t an early practicable time after a person

\footnotetext{
${ }^{880}$ Federal Rules of Civil Procedure, s 23(b)(1)(A).

${ }^{881}$ Federal Rules of Civil Procedure, s 23(b)(1)(B).

882 Federal Rules of Civil Procedure, s 23(b)(2).

${ }^{883}$ Federal Rules of Civil Procedure, s 23(b)(3).

884 The res judicata in this kind of cases is mostly for injunctive and declaratory relief. Monetary relief claims need to have a minimum procedural due process to bind absent members. See Brown v Ticor Title Insurance Co., 982 F.2d 386 (9th Cir. 1992); Phillips Petroleum Co. v Shutts, 472 U.S. 797 (1985).

885 Federal Rules of Civil Procedure, s 23(c)(2)(B).
} 
sues or is sued as a class representative',886 and at the same time, identify the 'claims, issues, or defenses' and appoint class counsel. 887

The certification consists of checking whether the lawsuit complies with the requirements of Rule 23(a) and fits within one of the categorizations of Rule 23(b). The inquiry must be comprehensive; trial judges are required to undertake a rigorous analysis and be convinced that the prerequisites of Rule 23(a) have been satisfied. ${ }^{888}$ Theoretically, since the Eisen ${ }^{889}$ decision, substantive merit-related inquiries should not be made at the certification stage, but because of the necessity of a 'rigorous analysis' as to its prerequites, class certification has a close relationship with the substantive merits of the dispute; depending on the specifics of the case, courts may have to engage in such an inquiry. ${ }^{890}$ Courts have to solve disputes as to whether certification requirements have been met and whether they are based on factual or legal assertions, even though this decision will not be binding on the trier of facts. ${ }^{891}$ While this might ease the concern over determinations of substantive issues, in any event, the decision must be strictly related to the certification requirements. This decision can be appealed within 14 days of the entering of the order. 892

Most class actions settle after certification, raising the importance of this stage in the judicial process. ${ }^{893}$ In practice, the trial occurs during the pre-trial phase, since the dispute will be solved promptly afterwards according to the outcome of class certification. Within the reality of such a context, the late Prof. Nagareda has suggested that it is

\footnotetext{
${ }^{886}$ Federal Rules of Civil Procedure, s 23(c)(1)(A).

${ }^{887}$ Federal Rules of Civil Procedure, s 23(c)(1)(B).

888 General Telephone Co. Of the Southwest v Falcon, 457 U.S. 147, 160-161 (1982).

${ }^{889}$ Eisen v Carlisle \& Jacquelin, 417 U.S. 156 (1974).

${ }^{890}$ For example, to assess the predominance requirement on a 23(b)(3) class action, the judge may have to determine, even if only preliminarily, the questions of law and fact that will be important in the lawsuit, a task which touches on the merits of the dispute. Nonetheless, under Eisen, evidence and the likelihood of success should not be considered at this moment. For a discussion on this question, see Robert G. Bone and David S. Evans, 'Class Certification and the Substantive Merits' (2001-2002) 51 Duke Law Journal 1521; General Telephone Co. v. Falcon, 457 U.S. 147, 160 (1982) ('sometimes it may be necessary for the court to probe behind the pleadings before coming to rest on the certification question').

891 See Initial Public Offerings Securities Litigation, 471 f.3d 24, 39-42 (2 ${ }^{\text {nd }}$ Cir. 2006).

892 Federal Rules of Civil Procedure, s 23(f).

893 Thomas E. Willging, Laural L. Hooper and Robert J. Niemic, Empirical Study of Class Actions in Four Federal District Courts: Final Report to the Advisory Committee on Civil Rules (1996) 179179.
} 
important for courts to 'say what the law is', especially when the dispute for class certification arises between different accounts of the governing law, an inquiry that is similar to the one that is made within the choice-of-law context in nationwide state-law based class actions. ${ }^{894}$ This is a crucial aspect for the development of the law on issues that are more prone to class action disputes. ${ }^{895}$

When a class is certified, all the persons that fall within the category delineated by the court as members of that class will be bound by the decision reached under the preclusion doctrine, meaning that if they do not opt out in the specified time period, none of the persons involved in the class will be able to re-litigate the matters decided therein. The same preclusion effects attach to class settlements, which constitute more than just an agreement of the parties but rather also an exercise of judicial authority. ${ }^{896}$

\section{Class Action and Securities Litigation}

In the United States, there were two important changes to the class action procedure in securities litigation, namely, the Private Securities Litigation Reform Act of 1995 and the Securities Litigation Uniform Standards Act of 1998.

The PSLRA brought major changes to securities litigation in the United States in order to address the increasingly significant problem of frivolous lawsuits. The Act restructured various procedural mechanisms and created a specific framework for the securities class action. Relevant to this part of this work are the reforms concerning the specific procedures that altered the basic process of a class action.

A problem that was fairly present was the existence of plaintiffs for hire; these were persons paid by the law firm to buy securities and be ready to act as a representative plaintiff when necessary. The PSLRA tried to curb the practice by imposing a requirement

${ }^{894}$ Richard A. Nagareda, 'Class Certification in the Age of Aggregate Proof' (2009) 84 New York University Law Review 97, 164-73.

895 See Chapter VI on the importance of reasoned and publicly available judicial decisions.

${ }^{896}$ Federal Rules of Civil Procedure, s 23(e)(2). See also Tobias Barrington Wolff, 'Preclusion in Class Action Litigation' (2005) 105 Columbia Law Review 717, 765 ('It is through the issuance of a certification order that a court acquires the power to bind absentees to a settlement agreement - a fact reinforced by Rule 23(e)'s requirement that a court provide further process to class members and then review and approve any settlement before such an agreement can take effect'). 
that plaintiffs should certify that they 'did not purchase the security that is the subject of the complaint at the direction of plaintiff's counsel or in order to participate in any private action arising under [the PSLRA]' and that 'the plaintiff will not accept any payment for serving as a representative party on behalf of a class beyond the plaintiff's pro rata share of any recovery'. 897

Addressing the same problem, another important procedural mechanism that was changed was the one to appoint the lead plaintiff. The PSLRA created a rebuttable presumption that the most adequate plaintiff, for the purpose of appointing a lead plaintiff, would be the party with 'the largest financial interest in the relief sought by the class'; ;98 this is a determination that can only be rebutted upon proof that either the chosen plaintiff 'will not fairly and adequately protect the interests of the class' 899 or 'is subject to unique defenses that render such plaintiff incapable of adequately representing the class'. ${ }^{900}$ The idea of the rule was to change the power balance between lawyers and plaintiffs, giving control of the litigation to those with more interest in closely monitoring the actions of class counsels and negotiating more fiercely in order to lower their fees. ${ }^{901}$ Congress' objective in enacting this provision was to increase the role played by institutional investors in securities class actions. ${ }^{902}$

The results intended by Congress were partially achieved. 903 Only public institutional investors stepped up as lead plaintiffs, while there was no significant change for private institutional investors. ${ }^{904}$ The same is true regarding the amount of recovery,

\footnotetext{
${ }^{897}$ Securities Exchange Act 1934, s 21D(a)(2)(ii) and (vi).

898 Securities Exchange Act 1934, s 21D(a)(3)(B) (iii)(I)(bb).

${ }^{899}$ Securities Exchange Act 1934, s 21D(a)(3)(B) (iii)(II)(aa).

${ }_{900}$ Securities Exchange Act 1934, s 21D (a)(3)(B) (iii)(II)(bb).

${ }^{901}$ Stephen J. Choi, Jill E. Fisch and A.C. Pritchard, 'Do Institutions Matter? The Impact of the Lead Plaintiff Provision of the Private Securities Litigation Reform Act' (2005) 83 Washington University Law Quarterly $869,869$.

902 Ibid .

${ }^{903}$ For an overview of the effects of the PSLRA, see Stephen J. Choi and Robert B. Thompson, 'Securities Litigation and its Lawyers: Changes During the First Decade After PSLRA' 06-26 NYU Law and Economics Research Paper Series 1.

${ }_{904}$ Choi, Fisch and Pritchard 870 (n 901).
} 
which was higher when public institutional investors were involved.905 Finally, attorney's fee awards were not reduced due to the increased participation of institutional investors. ${ }^{906}$

This change therefore altered the framework of class actions in the specific field of securities litigation, providing a more certain basis to the court in deciding who will act as the class representative. Even though the objectives of Congress in enacting the legislation were not completely achieved, the procedure for appointing lead plaintiffs was rationalized, creating, at least theoretically, a sound mechanism to align the incentives of lawyers with those of the class.

The second modification arose from the Securities Litigation Uniform Standards Act of 1998, created to prevent the ongoing flight of securities litigation from federal courts to state courts due to the enactment of the PSLRA. The act mainly prohibited the use of state law for securities class action litigation in which there were legal arguments that included securities fraud. 907

Notwithstanding the inconclusive evidence, the argument in favor of the legislation was that plaintiffs were moving their lawsuits to state courts to avoid the higher standards that were created after the PSLRA entered into force. ${ }^{908}$

905 Ibid.

906 Ibid. It is important to note that there were other studies claiming otherwise, but Professor Choi pointed to methodological problems with them, such as failing to control for the size of the case. Ibid 878.

907 The text of the legislation is:

'(f) LIMITATIONS ON REMEDIES.-

(1) CLASS ACTION LIMITATIONS.-No covered class action based upon the statutory or common law of any State or subdivision thereof may be maintained in any State or Federal court by any private party alleging-

(A) a misrepresentation or omission of a material fact in connection with the purchase or sale of a covered security; or

(B) that the defendant used or employed any manipulative or deceptive device or contrivance in connection with the purchase or sale of a covered security.

(2) REMOVAL OF COVERED CLASS ACTIONS.-Any covered class action brought in any State court involving a covered security, as set forth in paragraph (1), shall be removable to the Federal district court for the district in which the action is pending, and shall be subject to paragraph (1).' 15 U.S.C. §§ 78bb (f)(1) $\&(2))$.

${ }^{908}$ See Jennifer J. Johnson, Securities Class Actions in State Court 8-12 (Lewis \& Clark Law School Legal Research Paper Series No. 17, 2011). 
The statute provided for some exceptions, such that class litigation related to securities could still be pursued at the state level; these exceptions included, for example, the case of the 'Delaware carve-out', ${ }^{909}$ where the basis of the claim is the statutory or common law of the state in which the issuer is incorporated and involves equity holders of the issuer, in a situation where the case is related to communications made by the issuer to its equity securities holders or where it concerns decisions of these holders with respect to their voting rights in tender offers or appraisal rights. ${ }^{910}$

The result is that state law-based claims in class actions are preempted, 911 diminishing the scope of remedies that are available to plaintiffs to pursue recovery. This was another step taken by the U.S. Congress, this time through the restriction of avenues available to plaintiffs, to increase the difficulty of obtaining relief in securities fraud cases.

\section{Representative Actions: Brazil and Spain}

Brazil and Spain also have procedures in place to deal with problems that affect a wide range of plaintiffs, but their characteristics are not quite the same as the American class action model. ${ }^{912}$ Standing to sue is limited, preclusion rules are not as broad and moreover, the background civil procedure system is quite different. These systems seem to be designed in order to protect the interests that are more public, either by its substantive nature ${ }^{913}$ or by policy choice. ${ }^{914}$

In Brazil, the idea of a legal procedure to address disputes with a collective character is as old as the 1934 Constitution, which introduced the Popular Action mechanism, ${ }^{915}$ but its proper regulation came only in 1965 , with Law $4.717 / 65$. Even

\footnotetext{
${ }^{909}$ I borrowed the term from Ibid 8.

Securities Exchange Act 1934, s 28(f)(3)(i) \& (ii).

911 See also Dabit v. Merrill Lynch, 547 U.S. 71 (2006).

912 For a more in depth overview of class actions in Brazil and Spain, see Juan José Marín López, 'Las Acciones de Clase en el Derecho Español' (2001) 03/2001 InDret 1 Antonio Gidi, 'Class Actions in Brazil: a Model for Civil Law Countries' (2003) 51 The American Journal of Comparative Law 311.

913 Such as those within the concept of diffuse rights.

${ }^{914}$ As in the case of more common consumer torts, such as false advertisement.

915 The law regulating the procedure came only in 1965 (Law 4.717/65).
} 
though standing was broad, ${ }^{916}$ its problem was the limited scope of substantive matters that could be protected, encompassing only public heritage/public property and public morality. 917

Twenty years later, law 7.347/85 was enacted, introducing the Public Civil Action, a procedure with a broader scope than the former Popular Action; it included the general expression of 'diffuse or collective interests' as a subject matter that could be protected. Nonetheless, what was given with one hand was partially taken away with the other; art 5 of the law limited standing to initiate a Public Civil Action to the Prosecutor's Office, the Union, states, municipalities, state companies and associations that had been constituted for at least one year. ${ }^{918}$ Not long afterwards, legislation was passed to protect the collective rights of disabled persons, 919 securities investors, 920 children 921 and consumers, ${ }^{922}$ and within this legislation, specific changes and special circumstances to launch a Public Civil Action were provided for in each case. ${ }^{923}$

While it had been played around with during the 80 s and $90 \mathrm{~s},{ }^{924}$, the concept of aggregate litigation only became entrenched in the Spanish legal system with the new Spanish Civil Procedure Act, enacted in $2000 .{ }^{925}$ Only matters related to consumer or user lawsuits, in other words, those who are the final purchasers or users of goods and services, ${ }^{926}$ can be litigated through a representative mechanism in Spain.

916 'Any citizen may be a legitimate part to propose the annulation or declaration of nullity...' Law 4.717/65, art 1.

917 Humberto Dalla Bernardina de Pinho, 'A Tutela Coletiva no Brasil e a Sistemática dos Novos Direitos' Revista Diálogo Jurídico, 4 .

918 The scope of standing was also expanded later to the Public Defense Office.

919 Law 7.853/89 (Brazil).

920 Law 7.913/89 (Brazil).

921 Law 8.069/90 (Brazil).

922 Law 8.078/90 (Brazil).

923 E.g., the changes on standing for public civil actions in Brazil.

924 Spanish Law had specific legislation giving standing to consumer and user associations to propose class actions in cases of unfair advertisement (Law 34/1988 (Spain), art 25.1), antitrust (Law 3/1991 (Spain), art 19.2 a ), abusive contract terms (Law 7/1998 (Spain), art 16.3).

925 See López 3-4 (n 912) (According to the author, only in two very specific occasions class actions for damages were allowed in Spain before the Civil Procedure Act).

926 Ibid 4. 
Standing is broader than in Brazil, since the group of affected people,927 in addition to consumer and user associations ${ }^{928}$ and entities created for the specific purpose of protecting consumer and users, ${ }^{929}$ are allowed to bring a lawsuit. In practice though, this broader standing is of limited significance, since the people in the affected group have to be 'determined or easily determinable' and the group has to be constituted by a majority of the affected persons, ${ }^{930}$ which is not only a requirement that has to be proven by the group, but also raises questions of who, within the group, would control the direction of the lawsuit. 931

Therefore, in a manner that differs from the American class action, in which anyone can 'create' a class and sue, the trend of the class action procedure in Brazil and Spain is to enable specific parties in specific circumstances to use the judiciary to correct a wrong inflicted on the collective. The rights protected have either a public character or are rights of weaker groups that the legislator wanted to empower, such as consumers or the disabled.

Another crucial difference that confirms the trend is the preclusion effects arising out of these civil law class actions. In both Brazil and Spain, there is a separation between 'collective right' and the 'individual right', even when the individual right is litigated in a collective fashion. A class action in the United States binds all class members, whether they participate or not in the lawsuit. This is not the case in Brazil or in Spain. In Brazil, the effects of the judgment are secundum eventum litis to the individual, in other words, the effect depends on the results. ${ }^{932}$ If the plaintiffs are successful, the result is binding erga omnes, in the territory in which the judge (or court) has jurisdiction; ${ }^{933}$ if the lawsuit

\footnotetext{
927 Spanish Act of Civil Procedure, art 6.1.7.

928 Spanish Act of Civil Procedure, art 11.1.

${ }^{929}$ Spanish Act of Civil Procedure, art 6.1.8.

930 Spanish Act of Civil Procedure, art. 6.1.7.

931 López 6-7 (n 912).

932 Pinho 15 (n 917).

933 Law 7.347/1985 (Brazil), art 16.. This is becoming a contested matter, as Federal Judges in the Rio Grande do Sul Judicial Section have been deciding that some Public Civil Actions have a national effect due to the national character of the infringement at hand. See Defensoria Pública da União v Caixa Econômica Federal (4th Federal Court of Porto Alegre, Statement of Claim Acceptance in Public Civil Action n. 500837942.2014.404.7100) (04 February 2014) (deciding on the national effect of the Public Civil Action and citing Federal Judge Andrei Pitten Velloso in Defensoria Pública da União v União - Fazenda Nacional (14 ${ }^{\text {th }}$ Federal
} 
is dismissed by lack of evidence, anyone can sue again in his own individual capacity as long as new evidence is available. ${ }^{934}$ In the consumer context, even if the lawsuit is dismissed with prejudice, each individual consumer still maintains his right to sue. ${ }^{935}$ The same is true in the Spanish context. ${ }^{936}$

As mentioned above, Brazil has specific public civil action legislation for securities transactions. The procedure to be followed is the same as the one regulated in the Public Civil Action Law, ${ }^{937}$ but the scope of standing is limited to the Prosecutor's Office. ${ }^{938}$ Only cases of fraud, use of insider information and omission of relevant information, when there was a duty to inform, can be raised. ${ }^{939}$ Apparently, the mechanism has been used very sparsely in securities cases: a survey of the federal jurisprudence showed only three cases in which the Public Civil Action was used, ${ }^{940}$ while a search in the São Paulo state showed only 2 more relevant cases. ${ }^{941}$

For defendants, the prospects of multiple lawsuits, even after prevailing in a class action, may seem daunting, especially to those not familiar with the operations of civil procedure and the litigation framework in civil law countries. Even though this is not the best solution for the defendant, the differences in these systems alleviate the concerns

Court of Porto Alegre, Relief Anticipation in Public Civil Action n. 5019819-69.2013.404.7100) (10 May 2013).

${ }^{934}$ Law 7.347/85 (Brazil), Art. 16

${ }^{935}$ Law 8.078/90 (Brazil), art. $103 \S 1$.

936 See López 13 (n 912).

937 Law 7.347/85.

${ }_{938}$ Law 7.913/89, art 1; Usiminas v Donaldo Armelin (TRF3, $6^{\text {th }}$ Chamber, Civil Appeal n. 1275780) (2008); Usiminas v Ministério Público Federal (TRF3, $6^{\text {th }}$ Chamber, Instrumental Appeal n. 212476) (2004); Telebrás S.A. v Ministério Público Federal (TRF1, 2nd Chamber, Civil Appeal n. 93.01.04391-2 / DF) (1995).

${ }_{939}$ Law 7.913/89 art 1; Ministério Público do Estado de São Paulo v Comind Empreendimentos S.A. (STJ, $3^{\text {rd }}$ Chamber, REsp 8878 / SP) (2002) ('There is no basis in Laws n 7.347/85 and 7.913/89 to legitimate the Prosecutor's Office to act as the fiscal of the law in a damages action against financial institutions due to liquidation of debts already paid, when the extrajudicial framework to which they were subject has already come to an end').

940 Usiminas v Donaldo Armelin (n 938); Usiminas v Ministério Público Federal (n 938); Telebrás S.A. v Ministério Público Federal (n 938). There was also a criminal appeal that used the Public Civil Action Law as basis to impose collective moral damages on defendants convicted of insider trading (Luiz Gonzaga Murat Junior v Justiça Pública (TRF3, 5 ${ }^{\text {th }}$ Chamber, Criminal Appeal 45484) (2013)).

941 Telesp $v$ Ministério Público (TJSP, $7^{\text {th }}$ Private Law Chamber, Instrument Appeal n. 001396580.2002.8.26.0000) (2002); Walter Appel v Ministério Público (TJSP, 8 ${ }^{\text {th }}$ Private Law Chamber, Instrument Appeal n. 9034921-85.2007.8.26.0000) (2007). 
and the harm that might be caused by this possibility. In contrast to the American system, litigation in Brazil and Spain is cheaper. A clear reason is lack of discovery, ${ }^{942}$ which can consume thousands of man-hours, both on the part of defendants and plaintiffs, in respect of the former, giving the necessity to prepare the documents to disclose, and on the part of the latter, given the need to sort through the documents to prepare the case. ${ }^{943}$ In civil law procedure, the parties need to bring their own evidence to court, without the aid of the adverse party. ${ }^{944}$ This difference alone, when compared to the U.S. system, cuts the cost of litigation tremendously. Moreover, the harm of repetitive litigation to a defendant is a minor concern compared to the guarantee of due process of law in deciding on a plaintiff's rights. In other words, in civil law systems, the day in court remains an essential foundation of fairness in the judicial system, which, without causing a high degree of harm to defendants, guarantees the possibility of each plaintiff to claim his/her substantive right in court.

The problem is that, for conflict of interest and incentives purposes, the system still does not present the best solutions, since it is either dependent on public institutions to pursue litigation 945 or on not-for-profit consumer organizations. Adding this consideration to the ethical restrictions that might be faced by lawyers in respect of solicitation, it becomes almost impossible for this system design to provide incentives that would in fact enable aggregate litigation as an adequate solution for legal questions that involve a wide-ranging group.

\footnotetext{
942 To be fair, there is some possibility of discovery in the Brazilian and Spanish systems, but it is highly limited in comparison to the U.S. In Brazil, the Civil Procedure Code (Law 5.869/1973), art. 355, states that the judge may demand that a party shows a document or things in his/her possession. The same is true in Spain, according to article 328.1 of the Civil Procedure Law: 'each party may request the others to show documents that are not available and that refers to the object of the procedure or to the efficiency of evidence.' The scope is limited though - in Brazil the evidence has to be described as completely as possible, its objective and the circumstances in which the party requesting it, have to affirm that the document exists (art 356) while in Spain the consequence is that, in case of failure to show a requested document, the court may give weight to a copy of such document (art 329.1), requiring nonetheless that the party requesting the exhibition of the document must have some evidence of it.
}

943 On the plaintiff's side, the legal fees can easily amount to the hundreds of thousands.

${ }^{944}$ Gidi 320 (n 912).

945 On the problems of public enforcement in aggregate litigation, see Lemos. 


\section{The Dutch Act on Collective Settlement of Mass Damages}

The Dutch Act on Collective Settlement of Mass Damages was designed to solve a specific procedural problem that arose out of a mass dispute in the DES case, which had more than 18.000 litigants (and a potential group of up to 440.000).946

The Act provides that when there is a settlement between the defendant and an association or foundation representing claimants, the settlement can be sent to the Amsterdam Court of Appeal for approval, binding all those who are potentially claimants unless they opt-out of the settlement. ${ }^{947}$ As it is an opt-out procedure, notice becomes important; it has to be made directly to all known interested persons as well as through newspapers, both at the moment preceding the declaration that the settlement is binding, and after it. ${ }^{948}$ Other questions on its operation in the transnational environment will be dealt with in the next chapter.

It is becoming more common for funding to be provided by organizations and special purpose vehicles, which either collect money from individuals or are entitled to contingency fees in a successful settlement. ${ }^{949}$ This development is important because Dutch lawyers are not allowed to operate on a contingent fee basis due to ethical restrictions; ${ }^{950}$ as such, alternative avenues for dispute resolution funding in mass proceedings are needed.

\section{The English Group Litigation Order}

The English Group Litigation Order is a mechanism that provides 'for the case management of claims which give rise to common or related issues of fact or law' ${ }^{951}$ The

\footnotetext{
946 Hodges, The Reform of Class and Representative Actions in European Legal Systems 70-71 (n 604).

948 Ruud Hermans and Jan de Bie Leuveling Tjeenk, 'International Class Action Settlements in the Netherlands since Converium' in Ian Dodds-Smith and Alison Brown (eds), The International Comparative Guide to: Class \& Group Actions 2013 (5th edn, Global Legal Group Ltd. 2012) 7.

949 Ianika Tzankova, Netherlands National Report - part 2 (2008) 3.

950 Ibid 4.

951 Civil Procedure Rules 19.10.
} 
procedure was primarily developed through judicial discretion, due to the necessity that arose to manage cases with a high number of claimants in the $1980 \mathrm{~s},{ }^{952}$ becoming legislation in 2000. ${ }^{953}$

The mechanism allows for claims that present similar issues to be managed together by the same court. ${ }^{954}$ A register has to be set up to allow for claimants to join the procedure; ${ }^{955}$ a judge is then appointed to manage it and issue the necessary orders for the development of the litigation. ${ }^{956}$

The procedure is very flexible; the court can vary the issues that will be decided, pick one or more cases to proceed as test cases, and define the preclusion effects for those who might join the register after an issue is decided. ${ }^{957}$ As an opt-in procedure, only those who are part of the register will be bound by the decisions rendered by the court. 958

Even though the flexibility of the court is significant, a practice has emerged wherein test cases are used to decide the issues that are common to the group, allowing for the full litigation of these cases so that a clear picture can arise. 959

Finally, the loser pays principle still applies; this might give rise to financial consequences for claimants if no other arrangements between claimants and lawyers or third-party financiers are made. ${ }^{960}$

952 Hodges, The Reform of Class and Representative Actions in European Legal Systems 53 (n 604).

953 Neil Andrews, 'Multi-Party Proceedings in England: representative and group actions' (2001) 11 Duke Journal of Comparative \& International Law 249, 249.

954 Ibid 259.

955 Civil Procedure Rules Practice Direction 19B 6.1.

956 Hodges, The Reform of Class and Representative Actions in European Legal Systems 53 (n 604).

957 Mulheron 98-99 (n 708).

958 Civil Procedure Rules 19.12(1)(a).

${ }^{959}$ Hodges, The Reform of Class and Representative Actions in European Legal Systems 58 (n 604).

960 Ibid 60. 


\section{The German Capital Market Model Claims Act}

The Capital Market Model Claims Act was enacted in 2005 due to the need for German courts to deal with a securities case brought by 15.000 investors against Deutsche Telekom. ${ }^{961}$ At the time when the suits were filed, the German Civil Code did not allow for the coordinated management of all these claims. They had a similar factual background: an alleged false or misleading statement in connection with a public offering of American Depositary Shares. ${ }^{962}$

The act is restricted to claims for compensation due to false, omitted or misleading information and to claims regarding the fulfillment of contracts under the Securities Acquisition and Takeover Act. ${ }^{963}$

Similar to the English GLO procedure, the German mechanism requires that a register is created so that claimants can apply for the initiation of a model case. ${ }^{964}$ If there are 10 cases, a referral is made to a Higher Regional Court so that a model case can be established; ${ }^{965}$ the court that will try the matter then has to suspend pending proceedings that are factually or legally related to the model case. ${ }^{966}$ The Higher Regional Court will then decide on who will be part of the model case, considering the amount of the claim and if there is any agreement amongst the plaintiffs regarding a designated model plaintiff. ${ }^{967}$ The decision taken is binding on the inferior courts and binding on all interested parties, regardless of intervention. ${ }^{968}$

This proceeding was created as a management tool to diminish common issues that would have to be litigated many times; it is an interim proceeding, and as such, other

\footnotetext{
961 Ibid 77-78.

962 Ibid 78.

963 KapMuG, s 1(1).

964 KapMuG, s 2(1).

965 KapMuG, s (1).

966 KapMuG, s 7(1).

967 KapMuG, s 8(2).

${ }^{968} \mathrm{KapMuG}$, s 16(1).
} 
issues such as causation and individual damages will still have to be litigated at the lower court. 969

An important problem with the German system is the fee distribution for lawyers. Lawyers of the lead plaintiffs can only recover on the basis of the fees of their own clients, even though the work performed will benefit all of those who might be involved in the litigation; 970 this creates a free rider problem.

\section{Aggregate Litigation and the EU}

The last sections illustrated some of the developments of aggregate litigation in the Member States of the EU, but, in light of the cross-border character of securities transactions within the EU internal market, it is also important to consider whether, at the moment, the EU has a plan for the development of aggregate litigation.

The discussion regarding aggregate litigation in the EU took off in 2007, focusing on the consumer law and the competition law context. In its EU Consumer Policy Strategy 2007-2013, the Commission stated that it would 'consider action on collective redress mechanisms for consumers both for infringements of consumer protection rules and for breaches of EU anti-trust rules'; ${ }^{971}$ it effectively did this. The Commission published a Green Paper on consumer collective redress in 2008, ${ }^{972}$ a White Paper on damages of antitrust rules, ${ }^{973}$ and launched a public consultation in 2011, ${ }^{974}$ which was the basis for the European Parliament to adopt the resolution 'Towards a Coherent European Approach to Collective Redress'. ${ }^{975}$

\footnotetext{
969 Peter Rott, Evaluation of the Effectiveness and Efficiency of Collective Redress Mechanisms in the European Union - country report Germany (2008) 7.

970 Ibid 11.

${ }^{971}$ Commission, 'EU Consumer Policy Strategy 2007-2013' (Communication) COM (2007) 99 final, 11.

972 Commission, 'Consumer Collective Redress' (Green Paper) COM (2008) 794 final.

${ }^{973}$ Commission, 'Damages Actions for Breach of the EC Antitrust Rules' (White Paper) COM (2008) 165 final.

${ }^{974}$ Commission, 'Towards a Coherent European Approach to Collective Redress' (Public Consultation) SEC (2011) 173 final.

975 European Parliament Resolution 2011/2089/INI.
} 
This debate led the Commission to its current position, ${ }^{976}$ which is enshrined in the Commission Recommendation 'on common principles for injunctive and compensatory collective redress mechanisms in the Member States concerning violations of rights granted under Union Law'.977 The underlying policy of the recommendation is primarily, access to justice, and secondarily, some type of harmonization, even if on very broad terms, of the procedural design for aggregate litigation in Member States. ${ }^{978}$

Despite access to justice being the main underlying policy of the Recommendation, some of the principles established therein do not work towards this goal. These shortcomings are a result of the fear of an approximation to the U.S. system, which is explicit in recital 15, ${ }^{979}$ and of the creation of an environment ripe for abusive litigation. ${ }^{980}$ The main dimensions of the Recommendation that could have gone further in enhancing access to justice are reflected in the following: standing in representative actions, thirdparty funding, the preference for the opt-in system and the skepticism with contingent fees.

According to the principles established in the Recommendation, representative entities having standing for representative actions 'should have a non-profit making character'. 981 The problem with this approach is one of funding; either the entity will barely have funding, stripping the possibility for representative entities to become involved in complex situations, ${ }^{982}$ or the funding will be public, which transforms the representative entity in a de facto public entity, creating unnecessary costs for taxpayers,

\footnotetext{
976 See Commission, 'Towards a European Horizontal Framework for Collective Redress' (Communication) COM (2013) 401 final.

977 Commission Recommendation 2013/396/EU.

978 Commission Recommendation 2013/396/EU recital 10.

979 'Elements such as punitive damages, intrusive pre-trial discovery procedures and jury awards, most of which are foreign to the legal traditions of most Member States, should be avoided as a general rule'.

980 Commission Recommendation 2013/396/EU recital 10.

981 Commission Recommendation 2013/396/EU art 4(a).

982 See Duncan Fairgrieve and Geraint Howells, 'Collective Redress Procedures: European Debates' in Duncan Fairgrieve and Eva Lein (eds), Extraterritoriality and Collective Redress (Oxford University Press 2012) 2.78 .
} 
as explained in Chapter IV. The imposition of a non-profit character on representative entities undermines their role in mobilizing private parties to conduct litigation.

The principles on external funding also complicate matters from an incentives perspective. Third parties providing funding are prohibited 'to seek to influence procedural decisions of the claimant party, including on settlements'. 983 Such a provision increases the risk for the third-party funder, which consequently either increases the interest/stake that the funder demands or precludes the lawsuit altogether, leaving both funder and claimants worse off.

The opt-in system, in the aggregate litigation context, is also another problem for access to justice. ${ }^{984}$ Aggregate litigation mechanisms are better suited for negative claims, and as such it is unlikely that claimants would move to initiate litigation, leaving the responsibility of gathering claimants in the hands of lawyers. As explained before, due to ethical limitations lawyers may not pursue new clients actively; this situation thus weakens the economies of scale that are at the heart of the benefits arising out of aggregate litigation.

Finally, contingent fees are seen as undesirable and should be avoided if they create 'any incentive to litigation that is unnecessary from the point of view of the interest of any of the parties'.985 Firstly, it is not clear what an unnecessary incentive would be; however, a contingent fee arrangement is nothing more than a method of funding. Cases in which contingent fees would be used are unlikely to be litigated through a compensation system where the claimant pays upfront, especially in the aggregate litigation context where there should be one party managing the litigation. What the contingent fees system does is to put this responsibility back into the hands of the lawyer.

The nature of all of these prohibitions is to avoid abusive litigation, which is a worthwhile goal since litigation can be a costly endeavor for defendants. The problem is

\footnotetext{
983 Commission Recommendation 2013/396/EU 16(a).

984 Commission Recommendation 2013/396/EU art 21 provides that 'The claimant party should be formed on the basis of express consent of the natural or legal persons claiming to have been harmed ('opt-in' principle). Any exception to this principle, by law or by court order, should be duly justified by reasons of sound administration of justice.'
}

985 Commission Recommendation 2013/396/EU 16(a) arts 29, 30. 
that these measures avoid the problem but to a large extent do so by harming the main access to justice goal that aggregate litigation is designed to achieve. ${ }^{986}$

There are other ways to create procedural fairness and avoid abusive litigation or at least, to avoid the costs incurred by defendants associated with it - when implementing aggregate litigation systems, and the Commission has already picked up some hints for such a solution. The main aspect that would create a just system is the reimbursement of legal costs to the winning party, which is already enshrined in article 13 of the Recommendation. Instead of putting too many regulations around who may be a representative party, limiting the influence of external funders to the litigation and prohibiting contingent fees, the rules should be drafted in a way to give a wide degree of liberty to those taking the risk, but at the same time ensuring that they will be responsible for costs in case the claimants lose the litigation. Such an approach is even more relevant in cases where all of the claims are of negative value, since no single claimant would rationally take the litigation in his own hands, leaving the role of manager either to the representative entity or to the lawyer representing the claimants, who could fund the litigation themselves or rely on an external third party. In these cases, the representative entity, the lawyer or the external funder, should be made responsible for the costs, but should also be allowed to recover based on the risk and the possible upside of litigation. The only caveat is that recovery should be limited to a certain amount, the determination of which would depend on what can be deemed fair, to avoid abuse against claimants.

This design is an interesting one because it opens up the possibility for private parties to make use of aggregate litigation mechanisms, not only enhancing access to justice, but at the same time limiting the downside faced by defendants, who will be reimbursed for the costs of litigation if they successfully defend the case. Also, on the claimant's part, since those who will have the upside of the litigation are also on the hook in respect of its downside, it is likely that only cases with a considerable amount of merit will be litigated, avoiding the problem of nuisance litigation. If access to justice is the goal to be pursued, this approach is the best way of achieving it without undermining fairness to defendants.

986 Fairgrieve and Howells 2.79 (n 982). 


\section{Class Arbitration}

Class arbitration is a procedural device similar to the class action, developed to bring a dispute with multiple claimants/respondents to an end. Similarly to the class action, in a class arbitration there will be a decision to certify a class, defining the characteristics that would delineate the group of persons who would be bound by the final decision. ${ }^{987}$

Developed initially in the United States, the class arbitration has been around since at least 1982,988 and it is increasingly becoming an international phenomena. ${ }^{989}$ As a 'born and bred' American device, interesting questions arise in relation to its effective development and efficiency in the transnational forum since many countries may have restrictions against it.

The class arbitration mechanism is an interesting topic of study for this work because it encompasses a mechanism (at least when considered internationally) that could be, at least theoretically, used to efficiently solve securities disputes in a variety of different legal backgrounds.

\section{A. Historical Development of Class Arbitration}

Initially, in the United States, only parties to a contract or a related set of contracts, could be parties to a given arbitration, while class arbitrations were impermissible. ${ }^{990}$ Soon courts started accepting class arbitration, ${ }^{991}$ even though the initial prevalent position was that it was only allowed when parties explicitly agreed to it. ${ }^{992}$

987 The binding nature of the decision will depend on the due process standards of the arbitral seat or the applicable law and public policy considerations of the enforcing country.

988 See Keating v Superior Court, 645 P.2d 1192 (Cal. 1982).

989 See S.I. Strong, 'Enforcing Class Arbitration in the International Sphere: Due Process and Public Policy Concerns' (2008) 30 University of Pennsylvania Journal of International Law 1, 1; S.I. Strong, 'From Class to Collective: The De-Americanization of Class Arbitration' (2010) 26 Arbitration International 493.

990 Born 1227 (n 516). See also Vernon v Drexel Burnham \& Company, 52 Cal. App. 3d 706 (Cal. 1975).

${ }^{991}$ Keating v Superior Court, 645 P.2d 1192, 1209-10 (Cal. 1982).

992 See E.g. Champ v. Siegel Trading Co., 55 F.3d 269, para 18 ( $7^{\text {th }}$ Cir. 1995)('We thus adopt the rationale of several other circuits and hold that section 4 of the FAA forbids federal judges from ordering class arbitration where the parties' arbitration agreement is silent on the matter.'); Dominium Austin Partners, LLC v Emerson, 248 F.3d 720 ( $8^{\text {th }}$ Cir. 2001) para 23 ('Finally, we note that the goal of the FAA is to enforce 
This changed with a divided Supreme Court decision in Green Tree v. Bazzle,, 993 where the majority opinion concluded that the interpretation of the contract and the kind of procedure allowed by virtue of it, was a matter for the arbitrator to decide, and not one for the courts.

One of the reasons why arbitration was used in a widespread manner, especially in consumer and labor contracts, was the avoidance of class litigation. ${ }^{994}$ The use of arbitration was a way identified by businesses to effectively bar class treatment and the possibility of redress for negative claims. This decision effectively opened the doors for class treatment in arbitration proceedings in the United States when arbitration clauses were silent, since it gave the power to the arbitrator to decide. ${ }^{995}$ The business community reacted promptly, and not only did companies start to insert clauses into their contracts that explicitly barred class arbitration, but arbitral institutions also started to develop specific rules and procedures for these kinds of proceedings. 996

Two recent decisions confirm the trend of the possibility for class arbitration based on clauses that are silent on the matter. In JSC Surgutneftegaz v. President and Fellows of Harvard College, ${ }^{997}$ Harvard's investment managers complained that the russian gas company from which they had purchased American Depositary Receipts had depressed its net profits in order to reduce the dividends that the company was required to pay; it then filed a 'demand for class arbitration' with the AAA. ${ }^{998}$ The majority of arbitrators decided that class arbitration was allowed, despite the decision in Stolt-

the agreement of the parties, not to effect the most expeditious resolution of claims. See Baesler v Cont'l Grain Co., 900 F.2d 1193, 1195 (8th Cir. 1990). As such, an arbitration agreement should be enforced 'in accordance with its terms.').

993539 U.S. 444 (2003).

994 In some countries, consumer and labor regulation prohibits the use of arbitration clauses (e.g. Brazil). The justification is that in these relationships, consumers and workers are the weaker parties, and the justice system is designed in a manner such that they can effectively access a forum to claim their rights.

995 This was not explicitly stated in the decision, but it could be inferred from the power given to the arbitrator to decide the procedure allowed within the arbitration clause.

${ }_{996}$ See Phillip Allen Lacovara, 'Class Action Arbitrations - the Challenge for the Business Community' (2008)

24 Arbitration International 541, 543-44

9972007 WL 3019234 (S.D.N.Y. Oct. 11, 2007).

${ }_{998}$ Lacovara 548 (n 996). 
Nielsen SA v. Animalfeeds Int'l Corp ${ }^{999}$ in which Judge Rakoff had stated that New York law did not allow for class arbitration when the arbitration clause was silent. Judge Berman confirmed the award, thus allowing Harvard to pursue the claim representing a class on the grounds of Bazzle, finding that the arbitrators were competent to decide how to interpret the arbitration clause regarding procedural treatment.

The second case concerned a doctor suing a health insurance company for denying or delaying reimbursements of medical services fees. ${ }^{1000}$ In the same manner as the Harvard case, the arbitral tribunal issued a Class Construction Award allowing for class arbitration, but when challenged, the award was set aside based on the 'manifest disregard' doctrine, since the judge concluded that the NY law applicable at the time at which the arbitration clause was signed was settled in forbidding class arbitration when the arbitration clause was silent. ${ }^{1001}$ The judge's decision was reversed on appeal. The justification for reversal was that a court could only vacate an award under the 'manifest disregard' doctrine when the error amounts to an 'egregious impropriety', and not only 'an erroneous interpretation of the law'.1002

With these decisions, it became clear, at least in the United States, that the decision to entertain arbitration in a class form when arbitration clauses are silent is a matter for arbitrators to decide: moreover, courts will back up this decision, even when the applicable law provides otherwise. ${ }^{1003}$

Since arbitration was a way identified by these companies to avoid class actions and the perils that followed it, with these decisions and the new landscape in class treatment in arbitration, companies had to scramble to find other ways to prevent class

999435 F.Supp. 2 d 382 (S.D.N.Y. 2006).

1000 See Cheng v Oxford Health Plans, Inc., 2005 WL 5359732 (N.Y. Sup. Ct. N.Y. Co. 5 December 2006) and Cheng v. Oxford Health Plans, Inc., 45 App. Div. 2d 3d 356 (1 $1^{\text {st }}$ Dept 2007).

1001 Cheng v. Oxford Health Plans, Inc. (2006) (n 1000).

1002 Cheng v. Oxford Health Plans, Inc. (2007) (n 1000).

1003 Unless of course there is an 'egregious impropriety', which would be an extremely high standard to reach. In practice, arbitrators would have to acknowledge that the applicable law would forbid class treatment and still move forward with the procedure. 
disputes. An important parallel development to the class arbitration was the treatment of class action waivers by courts.

\section{B. Class Action Waivers}

Class action waivers began appearing in contracts in the 1990s after trade-journal articles started encouraging their use. ${ }^{1004}$ Due to the high litigation costs that are present in the United States, in many instances the class action was the only available means of redress for parties with low-value claims; it has been a widely-used procedure. While it is true that in some instances the class action mechanism has been abused, creating unnecessary social costs, within the U.S. legal system, it is, to some extent, the only way by which weaker parties can pursue some of their rights.

With this problem in mind, some of the U.S. courts started deploying the 'unconscionability doctrine' to address this problem. In general, to be unconscionable a contractual term has to be both substantively and procedurally unconscionable. ${ }^{1005}$ The doctrine is applicable to class action waivers and to arbitration clauses, since the FAA $\S 2$ provides that courts must enforce arbitration agreements 'save upon such grounds as exist at law or in equity for the revocation of any contract', ${ }^{1006}$ which is mainly a state matter. 1007

Most courts have upheld class action waivers against unconscionability claims, but some have refused to enforce them. ${ }^{1008}$ The denial in enforcing these clauses is important because a nationwide class can be certified in these states. ${ }^{1009}$

1004 J. Maria Glover, 'Beyond Unconscionability: Class Action Waivers and Mandatory Arbitration Agreements' (2006) 59 Vanderbilt Law Review 1735, 1746.

1005 Robert A. Hillman, 'Debunking some Myths about Unconscionability: a New Framework for UCC Section 2-302' (1981-1982) 67 Cornell Law Review 1, 2-3.

10069 U.S.C. $\S 2$ (2014).

1007 Peter J. Kreher and Pat D. Robertson III, 'Substance, Process, and the Future of Class Arbitration' (2004) 9 Harvard Negotiation Law Review 409, 425.

1008 Enforcing class action waivers, the U.S. Courts of Appeals for the Third, Fourth, Fifth and Seventh Circuits and many District Courts; refusing to enforce class action waivers, U.S. Court of Appeals for the Ninth Circuit and state courts in California and Illinois. See Glover 1751-52 (n 1004).

1009 Ibid 1754. 
Even though there is a theoretical possibility of avoiding class action waivers and arbitration clauses on unsconscionability grounds, most courts in the United States are enforcing them as a practical matter, with two recent Supreme Court decisions enforcing arbitration clauses and class action waivers outwith and within the arbitral process. ${ }^{1010}$

In this scenario, class arbitration will be a creature of consent. Parties who do not wish to engage in class arbitration will spell this out in their contracts, denying the possibility for the use of the mechanism. ${ }^{1011}$ Otherwise, parties will either accept the possibility of class arbitration by remaining silent in their contracts or will expressly provide in their contract for the design of the mechanism.

\section{The Types of Class Arbitration}

The development and practice of class arbitration created two main models: the hybrid model and the provider-created model.

\section{a. The Hybrid Model}

This model was created, at least in California, in the Keating v. Superior Court decision. ${ }^{1012}$ In the decision, the court stated that:

Whether... an order would be justified in a case of this sort is a question appropriately left to the discretion of the trial court. In making that determination, the trial court would be called upon to consider, not only the factors normally relevant to class certification, but the special characteristics of arbitration as well, including the impact upon an arbitration proceeding of whatever court supervision might be required, and the availability of consolidation as an alternative means of assuring fairness. Whether classwide proceedings would prejudice the legitimate interests of the party which drafted the adhesion agreement must also be considered, and that party should be given the option of remaining in court rather than submitting to class wide arbitration. ${ }^{1013}$

\footnotetext{
1010 See Oxford Health Plans LLC v Sutter, 133 S. Ct. 2064 (2013) and American Express Co. v Italian Colors Restaurant, 133 S. Ct. 2304 (2013).

1011 Kreher and III 423 (n 1007).

1012 Carole J. Buckner, 'Due Process in Class Arbitration' (2006) 58 Florida Law Review 185, 226-27.

1013645 P.2d 1192, 1209-10 (Cal. 1982).
} 
In this model, courts are an important part of the class arbitration mechanism; they retain jurisdiction and decide upon various other aspects during the development of the procedure, such as class certification, notice, discovery, settlements and issues of adequate representation. ${ }^{1014}$

\section{b. The Provider-Created Model}

The provider-created model is based on the involvement of arbitral institutions and the rules they have promulgated to guide the class arbitration procedure. Two known arbitral institutions that have developed a system of class arbitration are the AAA and JAMS, both headquartered in the United States. ${ }^{1015}$ The rules that they have created are patterned on the American class action system. ${ }^{1016}$ For example, the JAMS rules ${ }^{1017}$ provide that:

An action may be maintained as a class action if the prerequisites of subdivision (a) are satisfied, in addition to the criteria set forth in the Federal Rules of Civil Procedure, Rule 23(b). ${ }^{1018}$

The same is true of the AAA Supplementary Rules for Class Arbitration. ${ }^{1019}$ To allow a member of a class to represent all others, the arbitrator has to ensure that the following conditions are met:

(1) the class is so numerous that joinder of separate arbitrations on behalf of all members is impracticable;

(2) there are questions of law or fact common to the class;

(3) the claims or defenses of the representative parties are typical of the claims or defenses of the class;

(4) the representative parties will fairly and adequately protect the interests of the class;

(5) counsel selected to represent the class will fairly and adequately protect the interests of the class; and

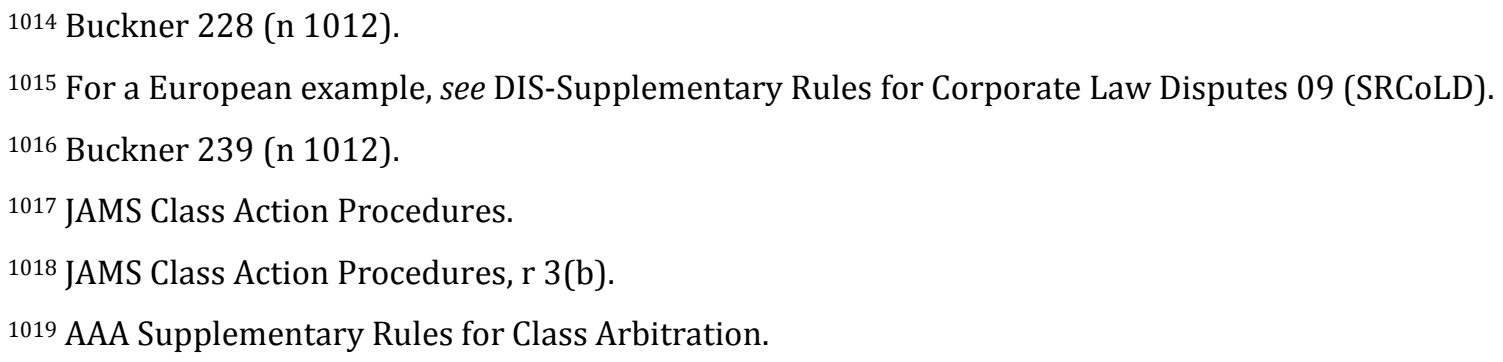


(6) each class member has entered into an agreement containing an arbitration clause which is substantially similar to that signed by the class representative(s) and each of the other class members. ${ }^{1020}$

Also, under the rules class arbitration can only be maintained if:

the questions of law or fact common to the members of the class predominate over any questions affecting only individual members, and that a class arbitration is superior to other available methods for the fair and efficient adjudication of the controversy. ${ }^{1021}$

These requirements are clearly modeled on the class action requirements in the U.S. class action system, and these models of class arbitration will, to a certain extent, mirror what is done in class actions and have similar effects. Due to this, the questions involving conflicts-of-interest and the funding of the claim are similar. The important question though, is not how class arbitration is similar to the class action, but how it differs, and how this difference might operate in favor of an enforceable international class dispute resolution system.

\section{Class Arbitration Outside the U.S.}

Class arbitration can be an interesting option for an aggregate dispute resolution system for securities disputes, especially in the context of disputes involving issuers and investors.

The possibility of using class arbitration in many jurisdictions is still not clear. As a starting point, arbitration is a creature of consent. The nomenclature 'arbitration agreement' and 'arbitration clause' translates the nature of the institute; arbitration is contractual, based on the will of the parties to submit their dispute to a private third-party instead of bringing the dispute to court. Theoretically, absent this consent, there are no grounds for a decision from an arbitrator to bind an unsuspecting third-party. ${ }^{1022}$ The arbitration agreement, constituting more than just the expression of consent of the

1020 AAA Supplementary Rules for Class Arbitration, s 4(a).

1021 AAA Supplementary Rules for Class Arbitration, s 4(b).

1022 ('[...] the arbitration agreement fulfils several important functions. The most important of these in the present context is that it shows that the parties have consented to resolve their disputes by arbitration. This element of consent is essential.') Alan Redfern and Martin Hunter, Law and Practice of International Commercial Arbitration (Sweet \& Maxwell 2004) 9. 
parties, is what legally gives the arbitrator the power to decide the dispute, that is, as the required source of the arbitral tribunal's jurisdiction. ${ }^{1023}$ It is this notion of consent that will give the arbitral award binding power in relation to those that, in one way or another, have agreed to be part of the arbitration, guaranteeing the binding effect of the decision.

Since consent is the only basis for a tribunal's jurisdiction, the important question in class arbitration is how consent is achieved, and whether the means of acknowledging consent within the legal system in which the arbitral tribunal's decision will be enforced, can be flexible, as it is within the class action procedure.

The possibility of class arbitration is a function of the type of dispute that is under discussion and the source of the legal relationships that need to be decided. With consent as the legitimating basis of the arbitral procedure, as long as consent is present, class arbitrations should theoretically be possible. ${ }^{1024}$

\section{E. Class Arbitration and the EU}

Class arbitration is viewed with skepticism in the EU, ${ }^{1025}$ and the hurdles that must be overcome to enable it are similar to those related to class actions. The due process and public policy concerns that were already discussed are also applicable in the context of class arbitration in the EU Member States. ${ }^{1026}$ To become a possibility, the design of class arbitration in European jurisdictions for securities transactions has to be made in a manner where due process is guaranteed through a mechanism of effective notice, in addition to being a possibility only where the public policy aspect of securities laws do not prohibit the arbitrability of the disputes.

1023 Ibid 10 ('Arbitrators do not hold public office and are not vested with pre-existing jurisdictional powers, which they acquire only by virtue of the parties' consent.'); See also Jean-François Poudret and Sébastien Besson, Comparative Law of International Arbitration (Sweet \& Maxwell 2007) 6-7.

${ }^{1024}$ For a more in-depth discussion on class and collective arbitration outside the U.S., see Strong, 'From Class to Collective: The De-Americanization of Class Arbitration' (n 989).

1025 Philippe Billiet (ed) Class Arbitration in the European Union (Maklu 2013) 233-235.

1026 Philippe Billiet and Laura Lozano, 'General Reflections on the Recognition and Enforcement of Foreign Class Arbitral Awards in Europe' in Philippe Billiet (ed), Class Arbitration in the European Union (Maklu 2013) 24-27. 
The positive aspects of a class arbitration system in the EU is twofold: firstly, access to justice is improved, and secondly, mass type disputes would be solved similarly across the board, avoiding the problem that multiple and possibly different judgments could arise out of the same fact pattern. Allowing a class action system for securities disputes in the EU context, in connection with a choice of law provision, would facilitate the creation of an internal securities market due to the homogenization of the rights attached to the same securities. Under the current scenario, this is not the case; the liability regime is dependent on the location of the investor's account. 1027

\section{Implications}

This chapter surveyed some of the most discussed aggregate litigation systems that are available today, showing important differences between them. As established in the previous chapter, one of the most important aspects in an aggregate litigation system is the one of incentives; ensuring that the persons who will steer the litigation have adequate incentives to do so is crucial for the success of the system.

In this context, some of the systems discussed are highly inappropriate for a privately-based enforcement regime, which should be the aim for the development of an adequate transnational system of dispute resolution for securities transactions. Here the examples are the representative action system, where the incentives lie in the public character of consumer associations and public bodies, and the German system, where lawyers bearing the burden of most of the work will only benefit from its clients fees, thus allowing for the possibility of this mechanism only where clients have a considerable stake in the matter. In terms of access, as these systems provide different avenues in addition to individual litigation, this is a step forward, but it still is too shy to constitute an efficient mechanism.

The Dutch settlement system seems to be moving in the right direction; even though lawyers are not able to work on a contingent fee basis, the use of outside funders who can do so allows a third party to have a significant stake in the matter, providing

1027 See Chapter X. 
incentives for the process to be pushed forward while at the same time aligning its interests with those of the plaintiffs'.

The main point that should be taken out of this chapter and the previous one is that a proper system of incentives is crucial for the design of an efficient aggregate litigation system. 


\section{Chapter X - Transnational Aspects of Dispute Resolution}

The purpose of law is to provide stability and certainty in social relations, giving space for the planning and improvement of economic output by diminishing duplicative protection costs that parties would have to entail in order to protect their assets. Legal systems may be more or less reliable, but legal certainty is what they strive for as otherwise they would be virtually useless, becoming a simple forum for discussion with no mechanism for the enforcement and resolution of real world problems.

When faced with transnational disputes, legal systems may then become ineffective systems with no real functionality. The problem arises out of the relationship between transnational transactions and the policy choices made in different legal systems. Since each jurisdiction is imbued of its own sovereignty, having power to decide which cases it wishes to entertain and what decisions should be enforceable in its own land, a legal system may not recognize a decision or may not apply a law to a transaction that would have been applied if the case had been litigated elsewhere.

In the securities context, this matter is even more evident due to the regulatory nature of securities law and its mandatory character, enhancing the uncertainties that may arise out of transnational transactions. For example, an investor that invests overseas through a foreign broker dealer or has securities of a foreigner issuer may have a very hard time litigating effectively in his own country since his court may not have jurisdiction over the dispute, the decision that may arise out of a local procedure may not be enforceable overseas where the broker-dealer has its assets, and even if it is, the costs of engaging in such transnational litigation might be too significant; ${ }^{1028}$ due to the

1028 One interesting example is the Case C- 168/02 Kronhofer v. Maier [2004] ECR I-06009, where Mr. Kronhofer, an Austrian resident, transferred money to an investment account in Germany after he was convinced by defendants to invest in a call option contract in the London Stock Exchange relating to shares. He lost a great deal of the money invested and sued to recover in an Austrian court; the matter was referred to the CJEU which decided that 'the expression 'place where the harmful event occurred' does not refer to the place where the claimant is domiciled or where 'his assets are concentrated' by reason only of the fact the he has suffered financial damage there resulting from the loss of part of his assets which arose and was incurred in another Contracting State.' 
uncertainty of the outcomes and the costs involved, it would be only worthwhile for an investor to pursue this path if there was a lot at stake.

This state of affairs limits immensely the transactions that can be made, having a negative effect both on investors who would want to have a wider option of investments and to capital seekers, who have a more limited pool of resources available.

This chapter is developed around the following question: 'what are the private international law problems related to liability in transnational securities transactions?' The objective is to identify these problems so that a solution can be developed in the next chapter.

To answer it, the chapter is divided in three sections: 1) jurisdiction and enforcement, 2) applicable law and 3) implications for securities disputes.

\section{Jurisdiction and Enforcement}

Any analysis of cross border legal problems has to start from a local perspective. By simply understanding the legal mechanisms available locally, it will be possible to extend the analysis to the transnational realm. Connections amongst different legal systems are made through jurisdictional analysis. Jurisdiction can be understood from both an internal and external perspective. The internal perspective relates to the rules with which a court has to comply to exercise decision-making power within its legal system, while the external perspective relates to the requirements that have to be complied with in a given forum in order to recognize that a foreign court had jurisdiction, and therefore that its judgment will be enforceable. ${ }^{1029}$

\section{Jurisdiction}

Jurisdiction is the power of a court to hear cases. With jurisdiction, a court can entertain a lawsuit, decide it and enforce the judgment. If a court decides without having jurisdiction, a higher court will overturn the decision. The jurisdictional rules of a legal

1029 See Ralf Michaels, 'Some Fundamental Jurisdictional Conceptions as Applied in Judgment Conventions' (2006) 123 Duke Law School Legal Studies Research Paper Series 1, 7-11. 
system define the scope of the court's power. This characteristic is part of the wider political system which can translate not only the determination of the role of courts in that particular legal system but also how that political system defines its importance, from its own perspective, to the outside world. Broader jurisdictional grounds may invade centers of interest of other nations, including local courts in the external relations considerations of the country.

Even though courts have the power to decide based on the jurisdictional rules that their legal system gives them, this power is only enforceable in the specific territory of the state to which this court belongs and over which it has physical control. A judicial decision that is not complied with will require officers of the law to arrest, collect assets or perform any other action that is necessary to oblige the losing party to comply. An American court cannot directly enforce one of its decisions in Brazil through the use of American officers without causing a serious international political incident.

Rules of jurisdiction vary. They are the expression of institutional choice in respect of dispute resolution in a state, while at the same time they are an exercise of that state's sovereignty. Limits to jurisdictional rules can be found in constitutions, the most important being linked to the idea of due process, which taken out of context, does not mean much since due process is a concept that can also vary substantially depending on the legal system being discussed. ${ }^{1030}$ From the plaintiff and defendant's perspective, jurisdiction rules are important as they shape the means of accessing the dispute resolution system of a state and of a matter being brought to litigation. Jurisdiction rules define who can sue and who can be sued in a given legal system and protects the defendant against the burden of litigating in a distant or inconvenient forum'.1031

\footnotetext{
1030 For example, due process in the United States means both the idea of substantive due process and procedural due process; even in the US, these concepts may not be seen as not having any specific meaning; Frank Easterbrook wrote in 1982 that the 'Court makes no pretense that its judgments have any basis other than the Justices' view of desirable policy. This is fundamentally the method of substantive due process' (Frank H. Easterbrook, 'Substance and Due Process' [1982] 1982 The Supreme Court Review 85, 125) In Brazil, the notion of due process is more significantly linked to the procedural side, encompassing the right to be heard, the right of the 'natural judge' and the right to not be convicted based on illegal evidence, amongst others (Gilmar Ferreira Mendes and Paulo Gustavo Gonet Branco, Curso de Direito Constitucional (7th edn, Editora Saraiva 2012) 641.
}

1031 World-Wide Volkswagen v Woodson, 444 U.S. 286, 292 (1980). 
On the other hand, jurisdiction rules are also important to mediate the relationship between different courts and sovereigns. On many occasions, conflict situations may present to more than one court the possibility of deciding the dispute. ${ }^{1032}$ Jurisdiction rules may therefore also be concerned with solving the conflict that may arise out of this conundrum.

This is an important inquiry for most countries as long as they are interested in engaging in international commercial relationships and have their legal system recognized as a trustworthy place in which the disputes that may arise out of these transactions can be resolved. In the securities context, this is even more relevant as the public policy aspect of securities regulation creates even more barriers to the solution of problems arising out of transnational transactions.

Policy concerns arising from jurisdictional rules can be therefore translated into two main groups: 1) the relationship between courts and parties to the disputes, which translates into the fairness of the system to the defendant and 2) the relationship between the forum state and other states. ${ }^{1033}$

\section{a. The relationship between courts and parties to the disputes}

The first dimension of jurisdiction is linked to the possibility for a court to exercise jurisdiction over a defendant. The focus of concern is vertical, as it does not include any considerations in respect of foreign sovereigns, being limited to the court-party relationship. The approach is diverse when comparing the American legal system to the civil law legal system.

In civil law systems, the approach to jurisdiction is usually based on the defendant's domicile, 1034 but might also be established in the place of contract

1032 Some areas that are prone to lead to jurisdictional conflicts are antitrust, securities regulation and insolvency when the dispute is related to global business networks. See Hanna L. Buxbaum, 'National Jurisdiction and Global Business Networks' (2010) 17 Indiana Journal of Global Legal Studies 165.

1033 Ralf Michaels in fact uses the distinction vertical/horizontal as paradigms from which the American system and the civil law systems think about jurisdiction. Nonetheless, the division is useful to categorize the questions that need to be discussed concerning jurisdiction. Michaels, 'Two Paradigms of Jurisdiction' 1027 (n 514).

1034 Brussels I Reg, 2; Brazilian Civil Procedure Code., art 94. 
performance ${ }^{1035}$ or in the place where a tort has been committed. ${ }^{1036}$ When disputes on in rem rights over immovable property are concerned, jurisdiction is exclusively established at the place where the property is situated. 1037 The jurisdiction analysis tends to be straightforward as a given court will either have or will not have jurisdiction; there will be no fairness or reasonableness inquiries as to whether the forum is a proper one for the dispute.

In the American legal system, the vertical jurisdictional analysis has a higher level of complexity, as there are many different doctrines through which a court may accept jurisdiction over a defendant in order to decide a dispute. While jurisdiction is a matter for the states, in the US, its outer limits are drawn by the Due Process Clause of the U.S. Constitution, ${ }^{1038}$ which has generated confusing jurisprudence on the matter. ${ }^{1039}$ While American states have the right to limit jurisdiction further, the practice has been to follow the guidelines set out by constitutional standards. ${ }^{1040}$

Jurisdiction can be general or specific. General jurisdiction is broader than in the civil law system, because, 'personal jurisdiction by service of process' and 'doing business' jurisdiction can also be used, in addition to defendant's domicile or residence, to establish the court's power over a defendant, legalizing the lawsuit.

'Personal jurisdiction by service of process' attaches if a person is served with process while being temporarily in the forum state, ${ }^{1041}$ as long as it does not violate 'traditional notions of fair play and substantial justice'. ${ }^{1042}$ The mere service of process

1035 Brussels I Reg, 5(1).

1036 Brussels I Reg, 5(3); Brazilian Civil Procedure Code, art 100, V.

1037 Brussels I Reg, 22(1); Brazilian Civil Procedure Code., art 95.

1038 Fourteenth amendment.

1039 Linda Silberman, 'The Impact of Jurisdictional Rules and Recognition Practice on International Business Transactions: The U.S. Regime' (2004) 26 Houston Journal of International Law 327, 329-31.

1040 Stephen B. Burbank, 'Jurisdiction to Adjudicate: End of the Century or Beginning of the Millennium?' (1999) 7 Tulane Journal of International and Comparative Law 111, 113.

1041 See Burnham v Superior Court of California, 495 U.S. 604 (1990).

1042 International Shoe Co. v Washington, 326 U.S. 310, 316 (1945). 
while the person is in the forum state is sufficient for that state to have jurisdiction over the person regardless of the matter at stake.

If the defendant is not situated in the state, than the 'doing business' basis of jurisdiction can apply. 1043 'Doing business' jurisdiction can be exercised when corporations are carrying on a continuous and systematic, even if limited, part of its business in the territory of that forum. ${ }^{1044}$ This is a highly-criticized doctrine, both within and beyond the the American legal system, ${ }^{1045}$ as it does not provide much certainty in practice as to what the standard really is in order to attribute the American courts with general jurisdiction, ${ }^{1046}$ weakening the Rule of Law principle. The problem becomes even more acute when potential foreign defendants are concerned with the possible consequences of transacting with U.S. parties, as being caught in a lawsuit in a foreign country without expecting it beforehand may be unfair, ${ }^{1047}$ diminishing the incentives of a foreigner to do business in the U.S. ${ }^{1048}$

Different legal systems therefore have different rules shaping the exercise of jurisdiction in respect of a given dispute; even if the rules were the same, without a set of rules to coordinate the exercise of jurisdiction, more than one court might be capable of being the forum in respect of the same dispute, opening up the possibility for irreconcilable decisions. The second inquiry in the analysis of jurisdiction concerns the availability of mechanisms that may be used to solve this problem.

\footnotetext{
1043 'Subsequent cases have derived from the International Shoe standard the general rule that a State may dispense with in-forum personal service on nonresident defendants in suits arising out of their activities in the State.' (Burnham v Superior Court of California (n 1041) 618)

1044 Perkins v Benguet Consolidated Mining Co., 342 U.S. 437, 445-446 (1952).

1045 For an in depth discussion on the doctrine, see Mary Twitchell, 'Why We Keep Doing Business with Doing-Business Jurisdiction' (2001) 2001 University of Chicago Legal Forum 171.

1046 See ibid 182-94.

1047 See ibid 197-202.

$1048 \mathrm{On}$ the other hand, a point to be made is that if a business wants to engage in 'doing business' in the U.S. it should expect to be subject to any kind of jurisdiction that may be exercised over them. In any event, it is the type of decision that is harder to make when the rules are not clear.
} 


\section{b. The relationship between the forum court and other courts}

The second aspect of jurisdiction, referred to by Professor Ralf Michaels as its horizontal aspect, ${ }^{1049}$ reflects the preferences of the legal system in taking into account considerations about the relationship between the jurisdiction and other legal systems.

The relationship between the forum court and other courts can either be integrated through an overarching system or be done unilaterally. Integrated systems can be created either through a quasi-federalist method such as the EU or through less complex but nonetheless complicated structures, such as international treaties. Unilateral systems on the other hand can either deal with the relationship with foreign courts on a case-by-case basis, as is the approach in the American system, or have hard and fast rules that do not take into consideration the relationship with foreign courts, as is the approach in the Brazilian system.

As transnational transactions increase, these types of rules become even more important. Jurisdictional rules that clearly provide where lawsuits can be pursued in these situations go a long way to facilitate them. The avoidance of parallel litigation and of multiple decisions is important to bring legal certainty to a given transaction, especially when there is nothing more than the legal system to be relied upon by the parties. 1050

\section{Integrated Jurisdiction Systems: the EU Example}

A good example of an integrated jurisdiction system is that of the European Union. The development of the European system for jurisdiction and enforcement of foreign judgments began with the enactment of the Brussels Convention ${ }^{1051}$ in 1968, a treaty made between Belgium, Germany, France, Italy, Luxembourg and the Netherlands, implementing the provisions of article 220 of the Treaty Establishing the European Economic Community; the Convention was a legal document and did not form part of the

1049 Michaels, 'Two Paradigms of Jurisdiction' 1027 (n 514).

1050 The importance of legal certainty and legal mechanisms becomes even more acute in financial markets and financial systems, which are essentially a legal construct. See Pistor (n 1).

1051 Convention of 27 September 1968 on Jurisdiction and the Enforcement of Judgments in Civil and Commercial Matters. 
EEC legislation. ${ }^{1052}$ The objective of the Brussels Convention was to 'facilitate recognition and to introduce an expeditious procedure for securing the enforcement of judgments'. 1053

The Brussels Convention was created in the context of European integration and was a consequence of the understanding that for cross-border trade to be efficient, the recognition of judgments should be easy. For this it would be important to establish common jurisdictional rules, as it would then become impossible to justify the denial of recognition and enforcement on the basis of exorbitant jurisdiction. ${ }^{1054}$

With the entry into force of the Treaty of Amsterdam in 1997, matters of civil jurisdiction came under the competence of the European Union, allowing for the creation of rules through the European Union's legislative process 1055 and thus making the enactment, in 2001, of the Brussels I Regulation possible.

The Brussels I Regulation establishes jurisdiction and enforcement rules for countries that are part of the European Union. The general rule is that a defendant can be sued in his domicile, 1056 but there are other specific grounds which provide that the defendant can be sued in the court of another Member State or that some Member State courts will have exclusive jurisdiction. ${ }^{1057}$ The mechanism to avoid parallel proceedings and disputes among different courts is based on articles 27 through 30 of the Regulation, establishing that the court first seized should be the one to decide if it has jurisdiction or not, and all the other courts have duty to stay their proceedings until a decision is reached. ${ }^{1058}$ If the court first seized decides that it has jurisdiction, the other courts have

1052 The European Community obtained power to legislate on Civil Jurisdiction matters only after the Treaty of Amsterdam. See Thalia Kruger, Civil Jurisdiciton Rules of the EU and their Impact on Third States (Oxford University Press 2008) 2.

1053 Brussels Convention, Preamble. On the importance of private international law for the integration of Europe, see Lorna Gillies, 'Creation of Subsidiary Jurisdiciton Rules in the Recast of Brussels I: Back to the Drawing Board?' (2012) 8 Journal of Private International Law 489, 494-98.

1054 Kruger 12 (n 1052).

1055 Ibid 15 See also Andrew Dickinson, 'European Private International Law: Embracing New Horizons or Mourning the Past?' (2005) 1 Journal of Private International Law 197.

1056 Brussels I Reg, art 2.

1057 See Brussels I Reg, ss 2 to 7.

1058 Brussels I Reg, art 27(1). 
a duty under European law to decline jurisdiction in favor of the court first seized. ${ }^{1059}$ As a general matter, the Brussels I regime is applicable when the defendant is domiciled in a Member State of the EU;1060 if the defendant is domiciled outside the EU, the applicable rules of jurisdiction will be those of his national legal system. ${ }^{1061}$

The mechanism provides certainty and efficiency to the functioning of the EU legal system. A single court alone will be able to decide whether it has jurisdiction; on this basis, long conflicts as to the place that would be the most appropriate for the resolution of the dispute can be avoided. The design of the system fulfills the need for legal certainty and efficiency as it coordinates the functioning and exercise of the judicial function amongst the courts of different EU Member States.

Despite the advantages that the Brussels I regime provides to the organization of different legal regimes and their interaction, the system is not without its flaws. An important area of concern is the improper use of the mechanism, which might cause delays in respect of the resolution of the dispute. For example, even when the parties have made a choice of court agreement but the lawsuit has been initiated in a different court, the court identified in the agreement has to wait until the court first seized has decided on its lack of jurisdiction. ${ }^{1062}$ This causes delays, especially when inefficient courts are first seized. ${ }^{1063}$

In 2009, a Green Paper ${ }^{1064}$ was released discussing the problems of the Brussels I Regulation and the possible avenues for its improvement. At the end of 2012, the European Parliament and the Council of the European Union adopted the Brussels I Recast, which will come into force on the 10 January 2015. The Brussels I Recast changed

\footnotetext{
1059 Brussels I Reg, art 27(2).

1060 Brussels I Reg, art 2(1).

1061 Brussels I Reg, art 4(1). See also Kruger 59 (n 1052).

1062 See Case C-116/02 Gasser v MISAT [2003] ECR I-14693 (the court second seized has to suspend the proceedings until the court first seized has accepted or declined jurisdiction) and Case C-159/02 Turner $v$ Grovit [2004] ECR I-03565 (the ECJ decided that anti-suit injunctions, mechanisms that could help to give teeth to choice of court agreements, are incompatible with the Brussels Regulation).

1063 In the literature, this is known as the Italian torpedo problem.

1064 Green Paper on the Review of Council Regulation (EC) No 44/2001 on Jurisdiction and the Recognition and Enforcement of Judgments in Civil and Commercial Matters COM(2009) 175 Final.
} 
the logic of jurisdictional conflict rules when choice of court agreements are at stake, shifting the power to decide on jurisdiction to the court designated in the agreement, 1065 thus solving the problem of the strategic use of courts to cause delay in litigation to which a choice of court agreement is relevant.

The Brussels Regime, while designed mainly with the integration of Europe in mind, is also applicable in some cases involving parties from third states. Thus, in cases where the claimant is not domiciled in an EU Member State but is suing someone who is, the jurisdictional rules applicable are those found in the Brussels I. 1066 The logic is extended to the doctrine of forum non conveniens, ${ }^{1067}$ which cannot be applied when the defendant is domiciled in an EU Member State. ${ }^{1068}$

The jurisdiction regime in the European context is quite different from that of the United States. The European rules are much more mechanical than the American ones, stripping courts of the scope to engage political considerations as to comity and convenience when deciding whether to entertain a dispute or not. The design of the system is a child of the needs of European integration, which emerged as an economic matter and has evolved in many different areas. ${ }^{1069}$ In the commercial and financial transaction areas, the development of a strong legal infrastructure for dispute resolution is essential and the Brussels Regime goes a long way in providing for this, at least when considering the space within the EU.

\section{Unilateral Jurisdiction Systems}

Unilateral systems are based only on the rules of the forum to mediate conflicts of jurisdiction between different legal systems. The rules and doctrines that are used in

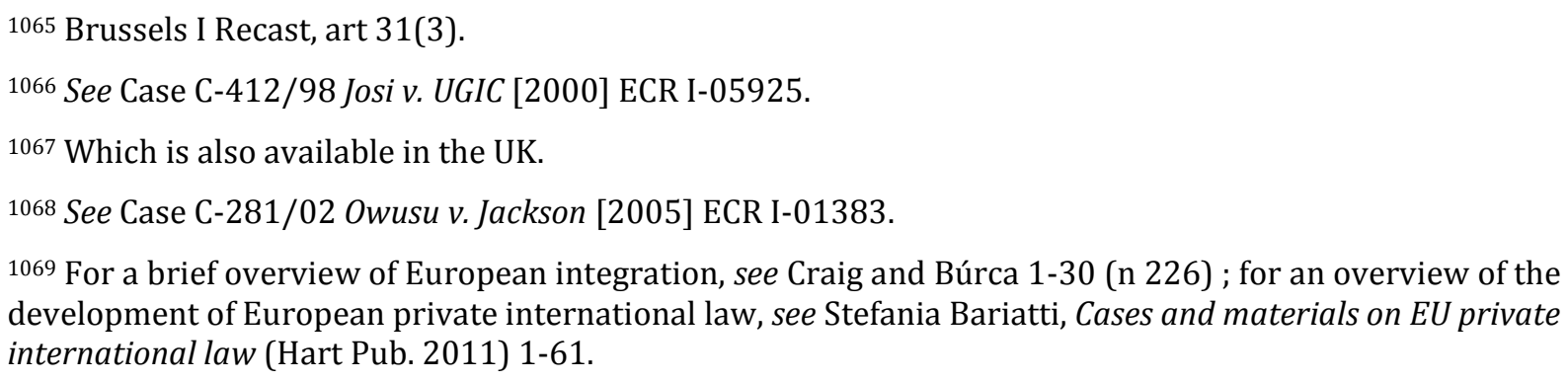


unilateral systems can either give the courts room in accepting jurisdiction to decide a case or can be highly specific, offering no possibility of discretion.

The United States system is of the first type; its jurisdictional relationship with other forums is limited through the doctrines of forum non conveniens and jurisdiction to prescribe'.

Forum non conveniens is a doctrine dating back to the 1940 s in the U.S. ${ }^{1070}$ that allows courts to decline jurisdiction when the case could be tried more conveniently in another forum. ${ }^{1071}$ The test was laid down in two decisions: GulfOil Corp. v. Gilbert ${ }^{1072}$ and Koster v. (American) Lumbermens Mutual Casualty Co. ${ }^{1073}$ The courts have to apply a test in deciding whether to decline jurisdiction, considering both private and public interests. The private interests to be taken into consideration include the relative ease of access to sources of proof and other practical problems that would make the trial of the case easier, as well as the enforceability of the judgment. 1074 Public interest, on the other hand, concerns administrative difficulties that courts may face and the burdens that may be imposed in a community that is not related to the lawsuit, such as jury duty. ${ }^{1075}$ The approach followed in the US is based on the notion that its courts should not waste energy in deciding disputes in which there is no relevant interest. One caveat is that the doctrine can only be applied if there is an alternative forum 'available', which means that the defendant must be 'amenable to process'.1076 Therefore, through this doctrine, US courts can decline to exercise their jurisdiction when they believe there is a more convenient forum for the dispute.

The other mechanism that is used by U.S. courts to mediate possible disputes with other courts and sovereigns is the doctrine of 'jurisdiction to prescribe'. The analysis

\footnotetext{
1070 Stephen B. Burbank, 'Jurisdictional Conflict and Jurisdictional Equilibration: Paths to a Via Media?' (2004) 26 Houston Journal of International Law 385, 393.

${ }^{1071}$ Martin Davies, 'Time to Change the Federal Forum Non Conveniens Analysis' (2002) 77 Tulane Law Review 309, 311.

1072330 U.S. 501 (1947).

1073330 U.S. 518 (1947).

1074 See Gulf Oil Corp. v. Gilbert (n. 1072) 508.

1075 Ibid 508-509.

1076 Piper Aircraft v Reyno, 454 U.S. 235, 254 fn22 (1981).
} 
made under this doctrine is geared to answer the question of when the U.S. can apply its own laws; it becomes especially important in cases with a relevant foreign component occurring outside the U.S. ${ }^{1077}$ Three landmark cases of the doctrine are Laker Airways Ltd. v Sabena, Belgian World Airlines, ${ }^{1078}$ Hartford Fire Insurance Co. v California, ${ }^{1079}$ and F. Hoffmann-La Roche Ltd. v Empagran. ${ }^{1080}$ In Laker, the U.S. District Court for the District of Columbia, while there was a parallel case running in London in respect of the same subject matter, confirmed what had been decided in United States v. Aluminum Co. of America1081 and was clear in stating that 'a country can regulate conduct occurring outside its territory which causes harmful results within its territory.' 1082 In addition, the Laker decision to grant 'jurisdiction to prescribe' was also based on the conduct of Laker and the appellants, who had airline routes in the United States. ${ }^{1083}$ Hartford took the 'jurisdiction to prescribe' a step further. The relevant activity that was under dispute took place in the U.K. and had been engaged by U.K. corporations and subjects doing business outside of the United States, under an extensive U.K. regulatory framework that did not prohibit it. ${ }^{1084}$ In effect, 'jurisdiction to prescribe' was upheld due to the substantive effects that the U.K. corporations' conduct had on the U.S. market and on the lack of an obligation imposed by the U.K. regulatory system to behave in the way they did. ${ }^{10851086}$ Despite the increasingly global U.S. regulatory aspirational trend that was established with Hartford, F. Hoffman-

1077 The bases of jurisdiction to prescribe are related to the legitimate stake of the state in the matter, which in the U.S. can be nationality, conduct on the territory or substantial effects in the territory, at least in accordance with the Restatement (Third) of the Foreign Relations Law of the United States. See Eleanor M. Fox, 'Modernization of Effects Jurisdiction: from hands-off to hands-linked' (2009) 42 International Law and Politics 159, 162-64.

1078731 F.2d 909 (1984).

1079509 U.S. 764 (1993).

1080542 U.S. 155 (2004).

1081148 F.2d 416 (2d Cir. 1945).

1082 Laker Airways Ltd. v Sabena, Belgian World Airlines (n. 1078) 922.

1083 'In addition to the protection of American consumers' and creditors' interests, the United States has a substantial interest in regulating the conduct of business within the United States. The landing rights granted to appellants are permits to do business in this country. Foreign airlines fly in the United States on the prerequisite of obeying United States law.' Laker Airways Ltd. v Sabena, Belgian World Airlines (n. 1078) 924.

1084 See Hartford Fire Insurance Co. v California (n. 1079) 819.

1085 This second question on the lack of obligation is a matter of comity and not one of jurisdiction to prescribe.

1086 Hartford Fire Insurance Co. v California (n. 1079) 798-799. 
La Roche began to delineate the limits of the U.S. jurisdiction to prescribe. Even though this was a global case also involving American parties, the Americans settled their disputes and the case that went all the way to the U.S. Supreme Court involved only the provision of remedies to foreign plaintiffs in respect of conduct that had been executed abroad and effects that were felt outside the U.S. The decision in this case was that in this type of situation, U.S. Laws would not be applicable. ${ }^{1087}$

The rule in the securities context, which was decided in Morrison $v$ National Australia Bank is similar. ${ }^{1088}$ The case at stake in Morrison was a foreign cubed class action, where foreign investors sued a foreign issuer for a transaction that occurred in the context of a foreign exchange. From a conduct and effects test, the U.S. Supreme Court moved to a focus standard, where 'the focus of the Exchange Act is not upon the place where the deception originated, but upon purchases and sales of securities in the United States, ${ }^{\prime} 1089$ making the place of the transaction the important connection factor for the applicability of U.S. Law.

'Jurisdiction to prescribe' is therefore a doctrine that is used to delineate and justify the applicability of U.S. laws when foreign elements are present. It is one doctrine within that of international comity, which is wider in scope and used also for the enforcement of foreign judgments. ${ }^{1090}$

It is important to underline the notion that in the U.S. system, while the considerations as to jurisdiction and foreign courts are, at times, taken from the perspective of what might happen in other courts and how appropriate it would be to extend U.S. laws outside the territory of the United States, they are generally made locally, from the perspective of the U.S. court and only valid within the U.S. legal system; this is

\footnotetext{
1087 'The price-fixing conduct significantly and adversely affects both customers outside the United States and customers within the United States, but the adverse foreign effect is independent of any adverse domestic effect. In these circumstances, we find that the FTAIA exception does not apply (...)'. F. HoffmannLa Roche Ltd. v Empagran (n. 1080) 164.

1088 Morrison v National Australia Bank (n 10).

1089 Morrison v National Australia Bank (n 10) 265.

1090 For an overview on the U.S. Comity Doctrine, see Donald Earl Childress III, 'Comity as Conflict: Resituating International Comity as Conflict of Laws' (2010-2011) 44 UC Davis Law Review 11, 47-59; Joel R. Paul, 'The Transformation of International Comity' (2008) 71 Law and Contemporary Problems 19.
} 
contrary to the European system, which has an overarching set of rules that include more than one national legal system.

Brazil, contrary to the U.S., presents a more rigid system for dealing with foreign jurisdictions. The Brazilian Civil Procedure Code establishes that Brazilian courts have jurisdiction to solve the dispute if the defendant is domiciled in Brazil, if the obligation has to be performed in Brazil, or if the lawsuit arises out of facts or acts that happened in Brazil; 1091 nevertheless, in these cases, decisions that are made in a foreign forum may be recognized in Brazil, as jurisdiction is not exclusive. ${ }^{1092}$ This jurisdictional power in Brazil is a broad one because the Brazilian courts will still accept jurisdiction even when there is a choice of a foreign forum to solve the dispute. 1093

Another important observation to be made is that, even though there is a provision for concurrent jurisdiction in Brazil, the Brazilian Civil Procedure Code is explicit in stating that a lawsuit in a foreign forum does not create lis pendens for Brazilian courts, allowing them to hear a dispute even though the dispute is already being litigated in a foreign court. 1094

In the context of a global world, the Brazilian system can be considered flawed; it is highly protective of its nationals and assumes jurisdiction in practically all cases where any of the requirements of article 88 of the Brazilian Procedural Civil Code are present, bringing foreigners to Brazilian courts simply due to the fact that they engaged in legal relations with Brazilians, even if it was explicit in a contract that the obligation was to be governed by foreign law and the dispute litigated in a foreign country. Such protectionism is undesirable absent a stronger justification because it makes dealing with Brazilian

1091 Brazilian Civil Procedure Code, art 88.

1092 Cases in which Brazilian courts have exclusive jurisdiction are regulated by article 89 of the Brazilian Civil Procedure Code: this includes matters related to immovable property in Brazil and succession regarding property situated in Brazil.

1093 '[...]A cláusula de eleição de foro existente em contrato de prestação de serviços no exterior, portanto, não afasta a jurisdição brasileira.[...]' (World Company Dance Show v Patrícia Chélida de Lima Santos (ST), 4th Chamber, REsp 1168547 / RJ) (2010)); 'a competência concorrente do juiz brasileiro não pode ser afastada pela vontade das partes'; 'válida a eleição de um foro estrangeiro, permanece a concorrência, isto é, a autoridade brasileira não estará impedida de apreciar a matéria' (American Home Assurance Company $v$ Braspetro Oil Services Company (STJ, 4th Chamber, REsp 251438 / RJ) (2000)). See also RS Components Limited v RS do Brasil Comércio Importação Exportação Ltda. (STJ, 3rd Chamber, REsp 804306 / SP) (2008)

1094 Brazilian Civil Procedure Code, art 90. 
counterparties dangerous, creating a risk for a foreign party who never desired to step into Brazil, of being dragged to its courts.

\section{Recognition and Enforcement of Foreign Judgments}

The recognition and enforcement of judgments is the external reflection of jurisdiction. Recognition and enforcement of foreign judgments is the acceptance of the laws and the exercise of power by another legal system. Recognition and enforcement is also a highly local political question that is decided by each legal system: some are more open to foreign judgments, accepting anything that does not go against its public policy, while others deny recognition and enforcement to all foreign judgments. ${ }^{1095}$

The enforcement of foreign judicial decisions is a policy choice that a country has to make. By accepting foreign judgments, a legal system recognizes that other courts also have the power to decide certain matters. Absent treaties or other type of integrated jurisdictional mechanisms, the decision to enforce a foreign judgment is made exclusively within the enforcing legal system.

As the recognition of a foreign judgment would imply the recognition of the exercise of power of a foreign state, countries are prone to recognize external judgments only to the extent that they can benefit from such a position. This becomes increasingly important as a country starts to engage in transnational commerce and its subjects develop the need for a legal infrastructure to dispose of any controversies with foreign counterparties. Two of the main objectives underpinning a legal system's recognition and enforcement of foreign judgments regime is the aim of attracting more business or of ensuring the enforceability of its own judgments in the courts of a foreign country, guaranteeing that its citizens may have legal redress mechanisms against outsiders.

As a unilateral approach to this question was not very effective for the purposes of creating a sustainable and robust transnational legal infrastructure, countries started to enter into bilateral treaties and even attempted to establish some multilateral ones to

\footnotetext{
1095 An example of a more liberal country would be the U.S., and an example of a more closed country would be The Netherlands. See Ralf Michaels, 'Recognition and Enforcement of Foreign Judgments' Max Planck Encyclopedia of Public International Law, 3 <http://opil.ouplaw.com/view/10.1093/law:epil/9780199231690/law-9780199231690e1848?rskey=dHgRET\&result=1\&prd=EPIL $>$ accessed 8 July 2014.
} 
provide for the recognition and enforcement of foreign judgments. One of the most successful examples is the Brussels Regime in the European Union.

\section{a. Integrated Recognition and Enforcement Systems: the EU Example}

As mentioned above, the Brussels Regime for jurisdiction and enforcement was born out of necessity. It was a result of the integration efforts that Europe was making and it established a comprehensive system to accommodate and coordinate the functioning of diverse legal systems. Jurisdiction rules were enacted to guarantee that no two courts would have jurisdiction over the same dispute, avoiding unnecessary conflicts between courts of different Member States.

Ensuring that no two courts would entertain the same dispute was not enough however. For an efficient legal infrastructure that could solve disputes in an efficient manner, more was required; this amounted to provisions on the recognition and enforcement of foreign judgments. Not only would a litigant know with certainty that only one court would be able to decide a case without worrying that other courts might entertain the same dispute, but moreover, the decision coming from that court would be enforceable in any other country under the same regime. ${ }^{1096}$

Under the Brussels Regime, the grounds for refusal of recognition are very limited. They include only the public policy exception, the existence of a judgment given with a default of appearance if the defendant was not served with process, preclusion and lack of jurisdiction on matters of insurance, consumer contracts and exclusive jurisdiction. ${ }^{1097}$

Thus, as the EU adopts a strict standard for non-recognition, if the procedure leading to the judgment is undertaken properly, in compliance with the minimum requirements for due process and if the exercise of jurisdiction is established in accordance with what it is provided for in the Brussels I Regulation, denial of recognition and enforcement will be highly unlikely. ${ }^{1098}$

\footnotetext{
1096 Brussels I Reg, art 35(3) prohibits raising the public policy exception regarding jurisdiction.

1097 See Brussels I Reg, arts 34 and 37.

1098 See Case C-7/98 Krombach v. Bamberski, C-7/98 [2000] ECR I-1395 and Case C-38/98 Renault v. Maxicar SpA [2000] ECR I-02973.
} 
This design creates a system that brings certainty to litigating parties. By guaranteeing the enforcement of judgments, the system enables reliance on the infrastructure of the legal system. Of course, the functioning of a system like this one presupposes trust in the judiciary systems of other countries. ${ }^{1099}$ Decisions that do not fall within the framework of the regime could cause distrust and, if persistent, lead to the political deconstruction of the system.

Another aspect of the system design is how simple it is to recognize and enforce a judgment. The cheaper and faster it is, the better for the robustness and efficiency of the legal system.

On this front, the way in which the Brussels Regime currently operates leaves some ground for improvement. As it is, judgments must go through a process of declaration of enforceability to be enforceable in a Member State country other than the one issuing the decision. ${ }^{1100}$ This is known as the exequatur procedure and its costs can be considerable for the average investor. ${ }^{1101}$ These average at around $€ 2,200$, ranging from $€ 1,100$ in Bulgaria to $€ 3,800$ in Italy in simple cases, and reaching €12,700 in more complex ones. ${ }^{1102}$ This procedure is considered to be an obstacle to the free circulation of judgments, creating costs and delays that may harm the EU internal market. ${ }^{1103}$ The problem has already been addressed by the Brussels I Recast, which retires the exequatur procedure. From 2015 onwards, a judgment of another Member State shall be enforced

1099 Ulrich Magnus and Mankowski Peter, Brussels I Regulation (2nd edn, Sellier 2012) 7-8.

1100 See Brussels I Reg, s 2.

1101 This procedure does not apply in relation to uncontested claims (see Regulation (EC) 805/2004) and claims under 2000 euros (See Regulation (EC) 861/2007).

1102 See Civil Justice: The Reform of the 'Brussels I' Regulation and the European Commission's Green Paper on the Free Circulation of Public Documents: Frequently Asked Questions, available at http://europa.eu/rapid/press-release_MEM0-10-677_en.htm.

1103 See European Commission, 'Proposal for a Regulation of the European Parliament and of the Council on jurisdiction and the recognition and enforcement of judgments in civil and commercial matters' (hereinafter, the 'Recast Proposal' or the 'Proposal'), COM(2010) 748 final, 3-4. 
in the same condition as judgments made in the country in which enforcement is sought, ${ }^{1104}$ subject to the usual grounds of non-recognition. ${ }^{1105}$

The new Brussels regime diminishes the hurdles for legal protection in the European environment. It is an interesting development within the European Union as it approximates the different legal systems that exist even further under the umbrella of the EU legal system. Despite some of its obvious advantages, some view these changes with skepticism and identify some dangers. ${ }^{1106}$ Only time will tell whether the changes have been good ones.

\section{b. Unilateral Recognition Systems}

Absent treaties, states are free to design recognition systems as they see fit. At a general level, different recognition and enforcement systems are designed in a similar manner, involving tests of finality of the judgment, personal jurisdiction by the court rendering the decision, service of process, due process and a public policy exception, sometimes also having a reciprocity requirement, 1107 and engaging comity considerations. ${ }^{1108}$

Even though the designs are, in general, similar, the application of recognition and enforcement rules always reflects the particular preferences and requirements of compliance with civil procedure of the country in which enforcement is being sought. For example, service of process on a foreign territory in a U.S. based dispute according to U.S. standards, ${ }^{1109}$ may preclude the recognition of the judgment in foreign courts. ${ }^{1110}$ The

${ }^{1104}$ Brussels I Recast, Recital 26; art 41(1).

1105 Public policy exception, judgment in default with no service and a judgment that is irreconcilable with a judgment given between the same parties in the Member State enforcing the judgment (Brussels I Recast, art 45).

1106 See Laurens Je Timmer, 'Abolition of Exequatur under the Brussels I Regulation: Ill Conceived and Premature?' (2013) 9 Journal of Private International Law 129.

1107 Samuel Baumgartner, 'Understanding the Obstacles to the Recognition and Enforcement of U.S. Judgments Abroad' (2013) 45 New York University Journal of International Law \& Politics 965, 971.

1108 Comity is 'neither a matter of absolute obligation [...] nor of mere courtesy and good will [...] it is the recognition which one nation allows within its territory to the legislative, executive or judicial acts of another [...]'.Hilton v. Guyot, 159 U.S. 113, 164 (1895).

1109 E.g., by delivery of the documents through a private person or by mail.

1110 Baumgartner 972 (n 1107). 
question is one of whether the decision will harm the sovereignty or the public interest of the state where recognition or enforcement is sought.1111

The specific rules in Brazil for the recognition and enforcement of foreign judgments fall neatly within this pattern. To be recognized, the foreign decision has to be proffered by an authority with jurisdiction, service of process has to be performed or the absence of a party in a default judgment has to be legally verified, the judgment must be final and duly authenticated by the Brazilian Consul and translated by a sworn translator, ${ }^{1112}$ and it can be denied if it offends sovereignty or the public order. ${ }^{1113}$

The system for recognition and enforcement in the United States is more peculiar: there is no overarching rule that is applicable all over the country, but the rules of each state govern recognition on the state territory, even in federal courts. ${ }^{1114}$ While the rules for recognition and enforcement are state-specific, they have been harmonized to a certain extent due to the Uniform Foreign Money-Judgments Recognition Act, ${ }^{1115}$ enacted by many U.S. states. ${ }^{1116}$ The remaining states apply the common law according to The Restatement (Third) of Foreign Relations of the United States. ${ }^{1117}$ Also, as soon as the decision is recognized, it becomes domesticated and the same protection afforded by the Full Faith \& Credit Clause is also given to the foreign judgment.1118

For the Uniform Foreign Money-Judgments Recognition Act, requirements are similar to the ones mentioned above: recognition is not given if the judgment is not

1111 Ibid 998.

1112 Resolution STJ 9 [2005], art 5.

1113 Resolution STJ 9 [2005], art 6.

1114 The existence of a federal common law for recognition and enforcement of foreign judgments was eliminated in Erie Railroad Co. v. Tompkins, 304 U.S. 64 (1938). See also Juan Carlos Martinez, 'Recognizing and Enforcing Foreign Nation Judgments: the United States and Europe compared and contrasted - a call for revised legislation in Florida' (1995) 4 Journal of Transnational Law \& Policy 49 Yuliya Zeynalova, 'The Law on Recognition and Enforcement of Foreign Judgments: is it broken and how do we fix it? ' (2013) 31 Berkeley Journal of International Law, 155.

1115 Uniform Foreign Money-Judgments Recognition Act.

1116 The act has been enacted by Alaska, California, Colorado, Connecticut, Delaware, District of Columbia, Florida, Georgia, Hawaii, Idaho, Illinois, Iowa, Maine, Maryland, Massachusetts, Michigan, Minnesota, Missouri, Montana, Nevada, New Jersey, New Mexico, New York, North Carolina, North Dakota, Ohio, Oklahoma, Oregon, Pennsylvania, Texas, U.S. Virgin Islands, Virginia, Washington.

1117 Zeynalova 156 (n 1114).

1118 Ibid 155. 
conclusive, if notice was not given to defendant, if the judgment was obtained by fraud, if the basis for the decision or the claim is against public policy, if the judgment conflicts with another final and conclusive judgment, if the proceeding in the foreign court was against an agreement by the parties or in case of jurisdiction based on personal service, if the court where the judgment was made was highly inconvenient; ${ }^{1119}$ enforcement is executed according to the procedure for enforcing another U.S. state judgment. ${ }^{1120}$ In addition to these requirements, some states also require reciprocity. ${ }^{1121}$

In the UK, the doctrine that was developed was more prone to the recognition of foreign judgments. The idea was that what was enforced was not the foreign judgment, but the obligation that it produced between the parties. As long as the court rendering the decision had competent jurisdiction over the defendant, the foreign judgment would be enforced. ${ }^{1122}$

The lack of an overarching international system of jurisdiction and recognition and enforcement of foreign judgments could be solved by a global convention on jurisdiction.

\section{An Attempt of a Global Convention on Jurisdiction}

Many of the problems arising from different legal systems having jurisdiction over the same dispute and the lack of certainty for recognition and enforcement of foreign judgments, could be solved by a global treaty on jurisdiction; even though there has been an attempt to create one, so far this has not become a reality.

The 'Judgments Project' at the Hague Conference on Private International Law was such an attempt; it had the goal of creating a global treaty for jurisdiction and the recognition and enforcement of foreign judgments, a true double convention. ${ }^{1123}$ The

\footnotetext{
1119 Uniform Foreign Money-Judgments Recognition Act, s 4.

1120 Uniform Foreign Money-Judgments Recognition Act, Prefatory Note.

1121 Zeynalova 158 (n 1114). The reciprocity requirement became known in Hilton v. Guyot (n. 1108).

1122 See Michaels, 'Recognition and Enforcement of Foreign Judgments' 2 (n 1095).

1123 See HCCH, 'The Judgments Project' (Hague Conference on Private International Law) <http://www.hcch.net/index_en.php?act=text.display\&tid=149> accessed 8 July 2014.
} 
work was initiated in 1992, and in 1999 a draft of a mixed convention was published.1124 Despite the effort put into the project, negotiations fell apart due to the different approaches that delegations from the U.S. and delegations from Europe had in understanding the concept of jurisdiction, ${ }^{1125}$ leading to the conclusion of a far more timid convention on Choice-of-Courts. ${ }^{1126}$ This is a convention that basically allows parties to choose courts to decide their disputes, avoiding legal uncertainty that may arise from the unacceptability of this kind of choice in some jurisdictions. So far the Convention has not been put into force, nor has it proved popular, as only the EU, Mexico and U.S. have signed it. 1127

Even though the Judgments Project was not successful, in 2012 The Hague Conference on Private International Law decided to resume working towards a future instrument on cross-border litigation. ${ }^{1128}$ The work is still at its initial stage and the reality of a treaty on the issue of jurisdiction and recognition of foreign judgments is still very far from reality.

\section{Arbitration}

The transnational aspect of judicial disputes is permeated by the efficiency problems of the legal infrastructure for dispute resolution. This is in part an explanation for the creation and growth of international arbitration in the past years. ${ }^{1129}$ Arbitration allows the parties to choose a mechanism for dispute resolution outside of the court structure that is nonetheless enforceable in courts.

\footnotetext{
${ }^{1124}$ A mixed convention would be one that includes not only required and excluded bases for jurisdiction, but also permitted ones, that would not be recognizable outside the country establishing jurisdiction based on them.

1125 See Michaels, 'Two Paradigms of Jurisdiction' 1009-11 (n 514).

1126 The Hague Convention of 30 June 2005 on Choice of Court Agreements.

1127 See HCCH, 'Status Table: Convention of 30 June 2005 on Choice of Court Agreements' (Hague Conference on Private International Law) <http://www.hcch.net/index_en.php?act=conventions.status\&cid=98.> accessed 8 July 2014.

$1128 \mathrm{HCCH}$, Conclusions and Recommendations adopted by the Council (Council on General Affairs and Policy of the Conference 17-20 April, 2012).

1129 Born 65-66 (n 516).
} 
This is possible due to the New York Convention, an international treaty in force in 149 countries, ${ }^{1130}$ which gives binding effect to international arbitration clauses and to agreements to arbitrate a dispute.

The number of countries in which the New York Convention is applicable makes it a truly global infrastructure for dispute resolution, avoiding many of the problems that may arise out of the use of choice-of-court agreements since these do not provide the same legal certainty to the parties as arbitration. This is mainly because of the different approaches for foreign judgments recognition and enforcement, such as the reciprocity requirement, and the insecurity of whether a court will decline jurisdiction when faced with a choice-of-court provision.

By choosing arbitration, the parties are able to avoid such problems since the New York Convention provides that agreements to arbitrate and arbitral awards have to be recognized by a Contracting State. ${ }^{1131}$

\section{Jurisdiction and Enforcement Aspects of Aggregate Litigation}

The involvement of parties of different jurisdictions may create difficulties in respect of a court's exercise of jurisdiction over all of them, especially in cases where the aggregate litigation mechanism is an opt-out one. With opt-in mechanisms, all of those plaintiffs who will be bound will have given their consent, as they will be the parties initiating the case. ${ }^{1132}$

In respect of the opt-out procedure, the matter is more complicated. How can a court have jurisdiction over plaintiffs that have not initiated the lawsuit and are not domiciled in the state in which the court is located? The approach of the Amsterdam Court

\footnotetext{
1130 See UNCITRAL, 'Status: Convention on the Recognition and Enforcement of Foreign Arbitral Awards (New York, 1958)' (UNCITRAL) <http://www.uncitral.org/uncitral/en/uncitral_texts/arbitration/NYConvention_status.html> accessed 8 July 2014.

1131 See New York Convention, arts II and III.

1132 In the EU, jurisdiction would be determined according to Brussels I Reg, arts 23 and 24.
} 
in certifying the Shell and Converium settlements under the WCAM procedure is enlightening. ${ }^{1133}$

Since this was a settlement procedure, the Dutch court treated the applicant parties, the representative of the class and those who would otherwise be defendants in a normal proceeding, as the plaintiffs, and the interested parties, the members of the class, as defendants. ${ }^{1134}$ By doing this, the court established jurisdiction in respect of investors domiciled in the Netherlands, according to Article 2 of Brussels I 1135 and, having established this, prorogated jurisdiction to those who were domiciled in other Members States through Article 6.1; Article 6.1 provides a basis for jurisdiction if 'the claims are so closely connected that it is expedient to hear and determine them together to avoid the risk of irreconcilable judgments resulting from separate proceedings'. In respect of the other foreign interested parties, the Dutch court used the open-ended provisions of article 3(a) of the Dutch Code of Civil Procedure, which states that Dutch courts have jurisdiction 'if either the petitioner or, where there are more petitioners, one of them, or one of the interested parties mentioned in the petition has his domicile or habitual residence in the Netherlands'.

The important aspect though is not whether the Dutch court could have had established jurisdiction, but if jurisdiction established in this manner could have been seen as a problem for the recognition and enforcement of the settlement/judgment in other countries. On this matter, Professor Halfmeier expressed his concern that it was not clear whether such an approach would be allowed under Brussels I; clarification is

1133 See Shell Petroleum N.V. Settlement, LJN: BI 5744, NIPR 2010, 71 (Court of Appeal Amsterdam 29 May 2009); Converium Settlement, NJ 2010, 683, NIPR 2011, 85 (Court of Appeal Amsterdam 12 November 2010); Converium Settlement, no. 200.070.039/01, LJN: BV1026 (Court of Appeal Amsterdam 17 January 2012).

1134 See Hélène Van Lith, The Dutch Collective Settlements Act and Private International Law (Erasmus School of Law 2010) 36-40 (Criticizing this approach as leading to multiple forums if more aggregate litigation mechanisms become available in Europe).

1135 In the Converium case, the court also used the basis of 5.1 to establish jurisdiction, the place where the obligation has to be performed, since the monies would be distributed by a foundation established in the Netherlands. 
required via the intervention of the CJEU. ${ }^{1136}$ In the international context, absent a treaty, the matter would be left to the recognizing state.

In respect of enforcement, the most pressing aspects that can be a barrier for recognition and enforcement, in addition to the issue of the jurisdiction of the court seized, is the question of proper notice and the adequate representation of the parties; these considerations will be analyzed in the section on public policy below.

\section{Applicable Law}

The question of applicable law is tied to the question of where the dispute is decided. The forum court will apply its own choice of laws rules to decide the proper law to be applied to the dispute. International treaties and efforts in harmonization are some of the avenues that have been pursued to diminish the number of different laws that could be applicable in a given dispute depending on the jurisdiction in which it is decided;1137 notwithstanding these efforts, uncertainty as to the applicable law in transnational securities transactions still exists and may represent a legal risk.

As set out above, there are three different types of disputes arising out of securities transactions: the issuer-investor, the financial intermediary-investor and finally, the financial information intermediary-investor dispute. The question as to which law will apply depends of what kind of dispute is at stake, the legal relationship between the parties and the forum of the dispute. As many financial disputes involve more than one type of cause of action, for example, a dispute based on securities laws and on the contractual relationship, these questions can become quite complex.

Absent treaties on applicable law, the determination of what law applies will fall to the forum deciding the dispute. Even if choice-of-law provisions are used, their applicability may depend on where the lawsuit is being pursued, as some legal systems

\footnotetext{
${ }^{1136}$ Alex Halfmeier, 'Recognition of a WCAM Settlement in Germany' [2012] 2012 Nederland International Privaatrecht 176, 178.

${ }^{1137}$ An important objective of conflict-of-laws rules is to provide uniformity of decision regardless of the court in which the matter is decided. See C.M.V. Clarkson and Jonathan Hill, The Conflict of Laws (4 edn, Oxford University Press 2011) 18-19.
} 
do allow for the use of choice-of-law, while in others the matter is not so clear. ${ }^{1138}$ Moreover, public policy considerations may play a role in the law applicable to the dispute. ${ }^{1139}$ From an ex ante perspective, it might be impossible to know which law will be applicable in a securities transaction involving parties who are situated in multiple jurisdictions, ${ }^{1140}$ creating serious legal uncertainty that can discourage transactions. ${ }^{1141}$

In the European Union, the legal infrastructure has been going through a process of harmonization, or at least, of conflict avoidance, due to the efforts in establishing a single market and the development of the underlying political structures required to make it work. This is done either through EU-wide legislation harmonizing a specific field of law and binding on all EU Member States, or legislation providing for solutions on applicable law in a transnational dispute, such as the Rome Regulations, which aim to discourage the use of forum shopping in the EU context, based on the determination of the substantive law applicable to a given dispute. ${ }^{1142}$

In the securities field, this transformation has been particularly intense. In the past few years the regulatory regime has become a full-blown one, operating mainly at the EU level and leaving little, regulation-policy wise, for the national regulators. ${ }^{1143}$

The breadth of subject matters covered by EU securities regulation is quite broad, as it can be seen in the discussion in Chapter V. The important issue for this chapter is that the rules have been harmonized; these harmonized rules are applicable throughout the

1138 In Brazil, the wording of the law is not clear and the judicial decisions on the matter have not been friendly to choice-of-law. See Anelize Slomp Aguiar, 'The Law Applicable to International Trade Transactions with Brazilian Parties: a Comparative Study of the Brazilian Law, the CISG, and the American Law about Contract Formation' (LLM, University of Toronto 2011) 4-7.; Dana Stringer, 'Choice of Law and Choice of Forum in Brazilian International Commercial Contracts: Party Autonomy, International Jurisdiction, and the Emerging Third Way' (2005-2006) 44 Columbia Journal of Transnational Law 959.

1139 See section 3 below.

1140 James Steven Rogers, 'Conflict of Laws for Transactions in Securities Held Through Intermediaries' (2006) 39 Cornell International Law Journal 285, 292.

1141 See Bradley Crawford, 'The Hague "Prima" Convention: Choice of Law to Govern Recognition of Dispositions of Book-Based Securities in Cross Border Transactions' (2003) 38 Canada Business Law Review 157, 163.

1142 If the substantive rules of law are harmonized, conflict-of-laws rules become unnecessary. Even though the regulatory framework is becoming increasingly harmonized, the liability scheme for breach of securities law is still mainly based on national law.

1143 Moloney, EC Securities Regulation 4 (n 227). 
$\mathrm{EU}$, whether they concern the duties of the issuer to provide information or the suitability test that the financial intermediary has to perform to sell securities to investors. Notwithstanding some small differences in implementation in nation states, the general legal framework is the same in respect of the standard of behavior for securities transactions across the EU area. The difference that is important for applicable law analysis is that liability for non-compliance with EU securities law is regulated nationally. ${ }^{1144}$

The two broad areas of applicable law that are related to liability aspects of securities transactions are contract and tort.

\section{A. Contract}

Applicable law in contracts is mainly based on private autonomy, that is, the freedom of the parties to select the law applicable to their relationship. ${ }^{1145}$ Absent choice, most systems have rules leading to a given applicable law, usually taking into consideration the relationship of the contract to a particular system and the most closely connected law.

Even though private autonomy plays an important role in choice-of-law, its acceptance is not universal; many countries either do not accept it or impose limitations on its use. Brazil, for example, does not accept a choice-of-law clause in disputes to be decided by courts due to the Introductory Law to the Brazilian Law Norms, ${ }^{1146}$ which in its article 9 provides that 'to qualify and regulate obligations, the applicable law will be the one of where the obligations have been constituted'; 1147 if the dispute is to be submitted to arbitration, then choice-of-law is allowed. ${ }^{1148}$

\footnotetext{
1144 See Directive 2004/109/EC, art 7; Directive 2004/39/EC, art 25(1) does not have any provisions on civil liability for non-compliance with its rules, providing that the forum state law and private international law regime constitute the framework for the imposition of liability. See also Busch (n 456).

${ }^{1145}$ Symeon Symeonides, 'Party Autonomy in Rome I and II from a Comparative Perspective' in K. BoeleWoelki and others (eds), Convergence and Divergence in Private International Law - Liber Amicorum (Eleven International Publishing 2010) 514-15.

1146 Decree-Law 4.657/1942. In case it is not clear where the obligation was constituted, the offeror's place of residence is deemed to be the place. See art $9 \S 2$.

1147 See also Aguiar 4-7 (n 1138).

${ }^{1148}$ Law 9.307/96, art $2 \S 1$.
} 
The U.S. on the other hand, while it is not as closed as Brazil, does not take a consistent position on the choice-of-law question due to the state law nature of the matter, to the extent that the party autonomy doctrine in the U.S. has been considered 'chaotic'. ${ }^{1149}$ The Restatement (Second) of Conflict of Laws is an influential secondary source in the U.S. but is not followed by all courts; ${ }^{1150}$ it allows for choice when the parties could have resolved the issue by an explicit provision in their agreement. ${ }^{1151}$ However, it limits the choice if the issue being addressed could not be resolved by an explicit provision in the agreement and at the same the time, the chosen state has no substantial relationship to the parties or the transaction, or if applying the law would be 'contrary to a fundamental policy of a state which has a materially greater interest' than the chosen state and where, in the absence of the choice, the applicable law ${ }^{1152}$ would be that of the place that 'has the most significant relationship to the transaction and the parties'.1153

In the EU, the approach of the Rome I Regulation to applicable law is based on private autonomy, allowing the parties to decide which law should be applicable to their contractual relationship; ${ }^{1154}$ this decision cannot displace laws that cannot be derogated from by agreement if the parties are either in the same country for national matters ${ }^{1155}$ or within one or more EU states for Union law purposes. ${ }^{1156}$

If no choice is made, article 4 defines the applicable law, which will be the one of the place where the seller or the service provider has residence. ${ }^{1157}$ In the securities context, contracts with multilateral systems, designed for buying and selling financial interests made in accordance with non-discretionary rules and governed by a single law,

\footnotetext{
1149 Mo Zhang, 'Party Autonomy and Beyond: an International Perspective of Contractual Choice of Law' (2006) 20 Emory International Law Review, 533.

1150 See Symeon C. Symeonides, Choice of Law in the American Courts in 2009: Twenty-Third Annual Survey (2010) 4-5.

1151 Restatement (Second) of Conflict of Laws $\$ 187(1)$.

1152 Restatement (Second) of Conflict of Laws $\$ 187(2)$.

1153 Restatement (Second) of Conflict of Laws $§ 188$.

1154 Rome I, art 3(1).

1155 Rome I, art 3(3).

1156 Rome I, art 3(4).

1157 Rome I, art 4(1)(a) and (b).
} 
will be governed by that law. ${ }^{1158}$ If the applicable law cannot be established by this analysis, it will be the law of the habitual residence of the party that has to provide the characteristic performance of the contract. ${ }^{1159}$ Finally, if it is clear that the contract is manifestly more closely connected with a country other than that established by the previous analysis, the law of most closely connected country will be applicable. ${ }^{1160}$

Another aspect of contractual conflict-of-laws provisions that may be relevant in securities transactions, in respect of financial intermediary-investor disputes, is the status of the investor; he might be deemed to fall within some dimension of the "weaker party' doctrine, that is, within the consumer category, either because of lack of information or a lack of bargaining power. ${ }^{1161}$ If this is the case, private autonomy is limited even further. In the European context, if a professional 1162 is transacting with a customer, ${ }^{1163}$ the applicable law will be the one of the habitual residence of the consumer if the professional pursues its commercial or professional activities in the place where the consumer has his habitual residence or if the activities are directed to that country. ${ }^{1164} \mathrm{~A}$ choice of law can still be made if it does not deprive the consumer of the protection afforded by the law of the country of his habitual residence. ${ }^{1165}$ In Brazil, which already has limits on choice of law, the rights granted to persons with consumer status are high, as any choice that might prejudice the consumer in comparison with the applicable Brazilian regime, is not allowed. ${ }^{1166}$ Finally, the U.S. does not have a specific regime for consumers; the general connection to the contract requirement for limitation of choice of law and fundamental public policy is applicable to curtail the effects of the choice of

\footnotetext{
1158 Rome I, art 4(1)(h).

1159 Rome I, art 4(2).

1160 Rome I, art 4(3).

${ }^{1161}$ Hans-W Micklitz, Jules Stuyck and Evelyne Terryn, Cases, Materials and Text on Consumer Law (Hart Publishing 2010).

1162 A professional is 'person acting in the exercise of his trade or profession'. Rome I, art. 6(1).

${ }^{1163}$ A consumer is 'natural person for a purpose which can be regarded as being outside his trade or profession'. Rome I, art. 6(1).

1164 Rome I, art 6(1)(a) and (b).

1165 Rome I, art 6.2.

1166 Brazilian Consumer Defense Code, art 51 I. A textual reading of the provision does not imply that choiceof-law is forbidden, but since arbitration clauses are not allowed in consumer transactions (art. 51 VI), the use of choice-of-law would also be severely limited.
} 
law. ${ }^{1167}$ A problem with the U.S. approach arises from the use of such a broad standard; it becomes unclear what the standards for consumer protection and applicable law are.1168

\section{B. Tort}

In respect of matters of tort, the applicable law is also an important issue as an action in a country may have effects in another country, for example, in respect of the price of the security being traded elsewhere. The main approaches to tort choice of law are either based on the place where the harm occurred, the place of the conduct or another type of interest analysis, engaging relevant connecting factors.

In Brazil, there is no distinction between extra-contractual and contractual choiceof-law regulation, as both are governed by Article 9 of Decree-Law 4.657/1942, which states, as mentioned above, that 'to qualify and regulate obligations, the applicable law will be the one of where the obligations have been constituted'. The text of the law does not clarify whether the lex loci delicti or the lex loci damni principle applies.

In the U.S., the approach to applicable law is similar to that in contract; the theories and doctrines for applicable law in torts are diverse and provide a highly complex landscape, moving from a single point of contact analysis (the lex loci delicti) to considerations about the underlying policies of the states involved in the dispute. ${ }^{1169}$ Comparing different policies and factors to determine the applicable law in a cross-border tort dispute undermines legal certainty, as it is never clear what the decision of the court will be: moreover, it obliges the judge to engage in a complicated analysis. ${ }^{1170}$ Even though certainty is not absolute in the United States at this moment, the different approaches have converged to provide for similar results, as most of the time the applicable law to a given tort dispute will be the law of the state favoring the plaintiff. 1171

\footnotetext{
1167 See Giesela Ruhl, 'Consumer Protection in Choice of Law' (2011) 44 Cornell International Law Journal 569, 587-92.

1168 See James J. Healy, 'Consumer Protection Choice of Law: European lessons for the United States' (2009) 19 Duke Journal of Comparative \& International Law 535.

${ }^{1169}$ Symeon C. Symeonides, 'Choice of Law in Cross-Border Torts: why plaintiffs win and should' (2009) 61 Hastings Law Journal 337, 346-48.

1170 Ibid 403.

$117186 \%$ to be more precise. See ibid 389-92.
} 
In Europe, due to the needs of European integration, the system of applicable law in non-contractual obligations is clearer and more systematized than in Brazil and the U.S., having been regulated by the Rome II Regulation. ${ }^{1172}$ The general rule is that the applicable law will be the lex loci damni, according to Article 4(1).1173 In some situations, such as car accidents, the location in which the damage occurred is easy to ascertain, but in others, such as negligent or fraudulent misrepresentation, 1174 this may be more complicated, undermining legal certainty. ${ }^{1175}$ The general rule is displaced if the persons involved have their habitual residence in the same country; in this case, the law of that country will be applicable.1176 Finally, when it is clear from the circumstances of the case that the tort is 'manifestly more closely connected' with another country, the law of that country will apply. 1177

Another important characteristic of the European regime for applicable law for non-contractual obligations is that the parties may choose by agreement which law they want to apply to their dispute after the event giving rise to the damage has occurred, ${ }^{1178}$ or if both parties are pursuing a commercial activity, they can agree on the applicable law before the event happens. ${ }^{1179}$

\section{Applicable Law in Arbitration}

The nature of the securities dispute will determine whether it may be prone to arbitration. Both the contractual and the issuer-investor dispute are theoretically capable of being submitted to arbitration, due to the legal link that an investor has with the

1172 Regulation (EC) 864/2007.

1173 'Unless otherwise provided for in this Regulation, the law applicable to a non-contractual obligation arising out of a tort/delict shall be the law of the country in which the damage occurs irrespective of the country in which the event giving rise to the damage occurred and irrespective of the country or countries in which the indirect consequences of that event occur.'

${ }^{1174}$ Andrew Dickinson, The Rome II Regulation: the law applicable to non-contractual obligations (Oxford University Press 2008) 328-29.

1175 Ibid 318-19.

1176 Rome II, art 4(2).

1177 Rome II, art 4(3).

1178 Rome II, art 14(1)(a).

1179 Rome II, art 14(1)(b). 
corporation, while the disputes with informational intermediaries is not so capable, unless the parties agree upon arbitration ex post.

Applicable law in arbitration is a complex issue. The initial assessment starts with the law applicable to the arbitration agreement, which might be different from the applicable law of the substantive part of the contract. This is a consequence of the severability presumption of the arbitration agreement, which is considered in its own right as a separate contract and not as part of the underlying contract. 1180

In the securities context, this consideration is especially important due to the public policy aspects that securities regulation has and that have to be considered in light of arbitration. 1181 Disputes involving securities may be non-arbitrable in some jurisdictions; therefore the law that will be applied to the arbitration agreement is important for the success of the dispute resolution process.

To this question, a single correct answer is still missing. There is no consistent approach to non-arbitrability across the globe. ${ }^{1182}$ The New York Convention provides that recognition and enforcement of an arbitral award may be refused if ' $[\mathrm{t}]$ he subject matter of the difference is not capable of settlement by arbitration under the law of that country',1183 giving the country in which the enforcement of an arbitral award is sought the possibility of protecting areas of its legal system that it believes should not be submitted to arbitration. This is an important consideration regarding the possible enforcement forums of the arbitral award, but it does not provide an answer which law should apply to define the non-arbitrability standard at the dispute resolution stage. Some of the approaches provide for the application of the law of the arbitral seat, the law of the forum in which enforcement may be sought or the law governing the arbitration agreement. ${ }^{1184}$ The best approach however would be one which engages the performance

1180 See Born 311-53 (n 516).

1181 More on this in the next section.

1182 See Born 516-35 (n 516).

1183 Art V(2)a.

1184 Born 520-23 (n 516). 
of an analysis similar to that which is done in relation to the public policy exception, regarding the closeness of the connection of the dispute. ${ }^{1185}$

The second question concerns the law applicable to the substantive part of the dispute, in the absence of agreement by the parties. National arbitral statutes differ in their approach and they may provide that arbitrators have to apply the conflict of law rules of the arbitral seat, those with the closest connection to the case, those that they deem to be 'applicable' or 'appropriate' or just disregard conflict of law analysis and apply directly the substantive law that they deem 'applicable' or 'appropriate'.1186

Generally, absent agreement of the parties, the approach to be taken is dependent on the law of the arbitral seat. This is an effect of article $V(1)(d)$ of the New York Convention that allows refusal of recognition and enforcement of an arbitral award if it is not in accordance with the laws of the country in which the arbitration took place. The problem is the public policy aspect of securities regulation. In some specific cases, even if the dispute is arbitrable, it might only be properly solved if it is done under the laws of the country where it will be enforced, otherwise the award may be denied recognition. Securities law is an area that falls neatly within these concerns.

\section{Applicable Law in Aggregate Litigation with Transnational Elements}

Applicable law questions in aggregate litigation with transnational elements can be a cause of concern, being also tied to questions of jurisdiction; this is the case even in the EU context, which has a more harmonized system of private international law.

In tort-like cases, which involve issuer - investor and information intermediary investor types of disputes, and where the lex loci damni principle usually applies - as it does in Europe by virtue of Article 4 of Rome II Regulation - there will be as many different laws as there are countries in which parties have been harmed.

The problem with this approach is that it also has effects on jurisdiction. In Roche v. Primus ${ }^{1187}$ the CJEU decided that, despite Roche BV in the Netherlands, together with

1185 Ibid 525-26.

1186 Ibid 2114-17.

1187 Case C-539/03 [2006] ECR I-06535. 
eight other companies in the Roche group situated in other countries having violated an European patent, since the Munich Convention establishes that violations have to be examined under the national law of each state in which the patent has been granted, decisions could not be irreconcilable for the purposes of Article 6(1) of Brussels I.

The situation in a securities case would be slightly different, as there would only be one provider of information that is false or misleading; however, given the lex loci damni principle in the Rome II, the logic would be the same and there would be as many applicable laws as jurisdictions in which persons have been harmed, since the liability in securities cases is to be established according to national law, precluding the use of art 6 (1) of Brussels I for jurisdiction purposes. The difference that exists in securities cases can be its salvation for aggregate litigation purposes; since the person issuing the statement is a single party, there is a possibility to engage the closest connection test for the purposes of determining the applicable law as provided for in art. 4(3) of Rome II, thus enabling the use of 6(1) Brussels I for jurisdiction purposes, and therefore allowing for a European-wide aggregate litigation mechanism.

Transnationally, in the absence of a treaty regulating the matter, the only choice left for dealing with the different applicable laws is to allow for the choice of law to regulate the relationship between issuers and investors; this solution could also be applied in the EU context. The argument against this approach is that issuers would then be allowed to choose their laws, undermining investor protection. Nonetheless, this is a system that could possibly work when foreign investors reach the market in which the issuer operates on their own, i.e. without the active distribution of securities in the investor's jurisdiction. This would not only facilitate aggregate litigation, but would also create a fair framework for investors, who, absent such provision, would actually have different rights depending on where they are based, notwithstanding that the securities are the same.

\section{The Public Policy Question}

The public policy provisions of a legal system are those that are applied irrespective of the agreement of the parties, due to their importance to the execution of 
the forum policy. 1188 They involve sensitive issues in many different areas, ranging from consumer protection ${ }^{1189}$ to anti-bribery legislation, ${ }^{1190}$ and have as their objective the protection of certain interests that are deemed to be important to the country. What falls within the public policy provisions of a legal system depends on the policy choices that are made by it; for example, the protection afforded to consumers in Brazil is much higher than in the United States. ${ }^{1191}$

The approach to public policy and what is accepted or not in a decision may also depend on the national or international character of the dispute. Courts tend to have a different interpretation as to what consists public policy when the dispute is international, especially in arbitration, as public policy will also involve considerations regarding the public policy of the state of the applicable law and the law of the arbitral seat of the dispute. ${ }^{1192}$

\section{A. Public Policy and Securities Disputes}

Securities law has an important public policy aspect as it protects investors from fraud and other inequitable acts in securities transactions, creating confidence and allowing for stronger securities markets. ${ }^{1193}$ A question with which academics have been struggling is when mandatory laws ${ }^{1194}$ of a foreign country are applicable to a cross-

1188 Donald Donovan and Alexander Greenawalt, 'Mitsubishi after Twenty Years: Mandatory Rules Before Courts and International Arbitrators' in Loukas Mistelis and Julian Dew (eds), Pervasive Problems in International Arbitration (Kluwer Law International 2006) 13 Joseph R Nuss, 'Public Policy Invoked as a Ground for Contesting the Enforcement of an Arbitral Award, or for Seeking its Annulment' (2013) 7 Dispute Resolution International 119.

${ }^{1189}$ In the EU context for example see Case C-240/98 Oceano Editorial v Roció Quintero [2000] ECR I-04941 (allowing courts to make preliminary assessments on the unfairness of a choice-of-court clause for jurisdiction purposes).

${ }^{1190}$ Donovan and Greenawalt (n 1188).

1191 Compulsory arbitration in Brazil in consumer relations is forbidden by law, being allowed only in very few cases, while, in the U.S., arbitration is generally allowed. Compare Código de Defesa do Consumidor, art. 51 VII with AT\&T Mobility v. Concepcion, 536 U.S. 321 (2011). For cases in which consumer arbitration in Brazil was accepted, see CZ6 Empreendimentos Comerciais Ltda. V Lúcio Maciel (TJRJ, 15 ${ }^{\text {th }}$ Chamber, Civil Appeal n. 2008.001.30250) (2008).

${ }^{1192}$ Nuss 127 (n 1188).

1193 See Chapter IV.

${ }^{1194}$ For an overview of the term, see Hans Christoph Grigoleit, 'Mandatory Law: Fundamental Principles' in Jurgen Basedow, Klaus Hopt and Reinhard Zimmermann (eds), Max Planck Encyclopaedia of European Private Law (Oxford University Press 2011). 
border transaction. ${ }^{1195}$ An example in the securities field is useful for the purposes of understanding this problem. An English company decides to sell securities to an American company. The English company is regulated by English securities laws in respect of its establishment and operation, as well as in respect of the duties it owes to its clients, in addition to the applicable antifraud provisions. The U.S., on the other hand, has its own laws on the selling of securities and the determination of the applicable standards to identify what constitutes fraud in a securities transaction. If there were a choice-of-law provision choosing English law to govern the transaction, would U.S. law be imposed when the U.S. company sued, or would the parties' choice be enforceable?

The real problem mainly arises when the dispute has to be decided or where the judgment has to be enforced in the forum of the law not chosen in the contract; in the example, this would be the the U.S. courts. ${ }^{1196}$ The court considering whether to recognize a decision or a choice-of-law that does not take account of its domestic policies and laws, will have to balance the importance of such policies with the promotion of international harmony; a given rule of law will become a public policy provision that can be used to justify the public policy exception provisions when the court considers that the domestic public policy at stake is more important than these international considerations. ${ }^{1197}$

Even though public policy provisions have a mandatory dimension, they may be relativized, depending on the interest in consideration. An interesting example is the interaction of the anti-waiver provisions of U.S. securities law with the choice-of-law and arbitration/forum selection agreements in overseas investment contracts. In Roby $v$. Corporation of Lloyd's, ${ }^{1198}$ the Second Circuit decided that notwithstanding the choice of English law and of English forum and the clear inapplicability of U.S. securities law in that

\footnotetext{
1195 For an overview on different theories, see Thomas G. Guedj, "The Theory of the Lois de Police, a Functional Trend in Continental Private International Law - A Comparative Analysis with Modern American Theories' (1991) 39 American Journal of Comparative Law 661; See also Russell J. Weintraub, 'The Extraterritorial Application of Antitrust and Securities Law: an inquiry into the utility of a "choice-of-law" approach' (1992) 70 Texas Law Review 1799.

1196 In the UK courts, this would be easily solvable, as the problem would concern a UK company with a UK choice-of-law on the contract: Rome I would be applicable. See Dicey, Morris and Collins, The Conflict of Laws (15 edn, Sweet and Maxwell 2012) 2103.

1197 Guedj 666 (n 1195).

1198996 F.2d 1353 (1993).
} 
forum, 1199 the choice-of-forum and choice-of-law should be upheld in the U.S. courts unless the agreement was unreasonable under the circumstances. ${ }^{1200}$ The unreasonable agreement concept can be translated into 'fraud or overreaching', 'inconvenience or unfairness of the selected forum', deprivation of a remedy under chosen law or the contravention of a public policy of the forum state. ${ }^{1201}$

In respect of the public policy aspect, in which U.S. securities legislation is recognized as 'protecting American investors from injury by demanding 'full and fair disclosure' from issuers' and 'deterring exploitation of American investors',1202 the court said that it would only 'be contravened if the applicable foreign law failed adequately to deter issuers from exploiting American investors'. ${ }^{1203}$ The court's next step was to recognize that English law provided similar remedies as U.S. securities law, ${ }^{1204}$ protecting investors from fraud and misrepresentation, ${ }^{1205}$ while at the same time, to accept that for the purposes of disclosure requirements, the transaction fell within Regulation $\mathrm{D}^{1206}$ and that nonetheless, English law provided Lloyd's 'adequate inducement to disclose material information'. ${ }^{1207}$ While recognizing that the application of U.S. securities law would give the plaintiffs a higher chance of victory, the Second Circuit established that 'ample and just remedies' were available under English law and therefore that the U.S. public policy

1199 ' [...] neither an English court nor an English arbitrator would apply the United States securities laws, because English conflict of law rules do not permit recognition of foreign tort or statutory law.' Roby v. Corporation of Lloyd's (n. 1198) 1362.

1200 Roby v. Corporation of Lloyd's (n. 1198) 1363.

${ }^{1201}$ Roby v. Corporation of Lloyd's (n. 1198).

1202 Roby v. Corporation of Lloyd's (n. 1198) 1364.

${ }^{1203}$ Roby v. Corporation of Lloyd's (n. 1198).

${ }^{1204}$ Even though that while in the U.S. reliance would not have to be proved and controlling persons would also be liable for misrepresentation, this would not be the case in English law. Roby v. Corporation of Lloyd's (n. 1198) 1365.

1205 Roby v. Corporation of Lloyd's (n. 1198).

1206 The U.S. Securities Regulation that exempts issuers from disclosure requirements.

${ }^{1207}$ Roby v. Corporation of Lloyd's (n. 1198) 1366. 
on securities legislation was protected. ${ }^{1208}$ The same approach has been taken by the Fifth, ${ }^{1209}$ Eight $^{1210}$ and the Ninth Circuits. ${ }^{1211}$

Public policy provisions therefore have at their core rules from which parties cannot contract out, due to policy interests of a country. They matter for private international law because they may allow a country to deny the recognition and enforcement of a foreign decision on the basis that the decision is against the public policy of the country; moreover, it might allow it to keep specific substantive matters exclusively within the jurisdiction of national courts. As it was shown, they can be relativized in certain jurisdictions as long as the contracting out does not lead to the complete forfeiture of the protection that the protected party would enjoy under the rules that have been contracted out, even though the level of protection may be lower.

\section{B. Public Policy and Notice in Aggregate Litigation}

The public policy aspects of aggregate litigation are related to the globallyrecognized right to a fair trial, which guarantees notice of process, recognized in many constitutions and international treaties ${ }^{1212}$. As a background matter, it is important to note that fundamental rights of this type are not absolute; they may be subject to limitations when these are justified by a legitimate aim and proportional measure to achieve this aim. ${ }^{1213}$

1208 Ibid.

${ }^{1209}$ Haynsworth v. The Corp, 121 F.3d 956 (5 $5^{\text {th }}$ Cir. 1997).

1210 Bonny v. Society of Lloyd's, 3 F. 3d 156 (1993).

1211 Richards v. Lloyd's of London, 135 F.3d 1289 (1998).

1212 The due process clause in the U.S. Constitution, art 5, LIV of the Brazilian Constitution, art. 6 of the European Convention on Human Rights, art. 47 of the Charter of Fundamental Rights of the European Union, art 8 of the American Convention of Human Rights, among others.

1213 Lithgow and Others $v$ the United Kingdom (1986) Series A no 102 para 194('[A] limitation will not be compatible with [a fair trial] if it does not pursue a legitimate aim and if there is not a reasonable relationship of proportionality between the means employed and the aim sought to be achieved'); ('It should, however, be borne in mind that fundamental rights, such as respect for the right of the defence, do not constitute unfettered prerogatives and may be subject to restrictions. However, such restrictions must in fact correspond to the objectives of public interest pursued by the measure in question and must not constitute, with regard to the aim pursued, a manifest or disproportionate breach of the rights thus guaranteed') Case C-394/07 Gambazzi v. DaimlerChrysler [2009] ECR I-02563 para 29. 
Notice is only an issue in opt-out procedures, since in opt-in procedures the plaintiff will actively consent to engage in litigation. The purpose of notice, as a general matter, is to inform a party that there is a legal proceeding (the outcome of which will bind him) in course, in order to allow the person to mount a defense. Its existence therefore becomes crucial to bind plaintiffs in an opt-out procedure. As if they were defendants, proper notice should be sufficient ground to guarantee that a trial, or settlement, was not unfair; as argued by Professor Feintman, this is more a matter of estoppel than of positive consent. ${ }^{1214}$ The fundamental right to a fair trial should not be seen as having been breached if the party has knowledge about the procedure and has not opted out or become actively involved in the process.

There are many international instruments that allow for service of process from one jurisdiction to another, such as The Hague Service Convention of 1965 and Regulation (EC) $1393 / 2007$. Given that these are legally permitted mechanisms, notice through them should be sufficient to bring absent plaintiffs to the legal dispute, binding them in respect of the outcome, having given them the opportunity to opt-out or to become involved in the lawsuit. To this extent, if notice is properly given, the only remaining objection to aggregate litigation in a foreign country would be the aggregate character of the lawsuit, which becomes a weak argument per se absent a fair trial violation.

A problem with the normal legal ways of giving notice is that they may be costly. In this respect, the approach initially taken by the Amsterdam court in the Dexia case was to request notification by ordinary post, contrary to the requirement of a registered letter per Regulation (EC) $1393 / 2007 ; 1215$ it justified this determination by saying that the parties may raise any objections at the recognition and enforcement phase. ${ }^{1216}$ Since this approach was clearly prone to problems of recognition of the settlement agreement, the

\footnotetext{
${ }^{1214}$ Richard Feintman, 'Recognition, Enforcement and Collective Judgments' in Arnaud Nuyts and Nikitas E. Hatzimihail (eds), Cross-Border Class Actions: The European Way (Seillier European Law Publishers 2014) 107-08.

${ }^{1215}$ Art 14.

1216 Lith 70-71 (n 1134).
} 
Amsterdam court started following the guidelines of Regulation (EC) 1393/2007 in subsequent cases. ${ }^{1217}$

The preceding discussion assumed that the address of the persons to be notified was known, but in many situations this would not be the case, which could complicate matters tremendously. For example, in the EU context, Regulation (EC) 1393/2007 does not apply when the address of the person to be served is unknown, ${ }^{1218}$ which may impede the recognition of the judgment in other Member States. ${ }^{1219}$ In fact, as there are no international mechanisms regulating opting-out of aggregate litigation, it becomes impossible to guarantee that foreign class members will be bound (even when notice by newspapers is widely used, as was the case in the Shell Dutch settlement ${ }^{1220}$ ), undermining the legal certainty of the decision at a transnational level.

As the methods for notice under different national laws can become a problem for aggregate litigation, a solution based on arbitration as a method of dispute resolution may facilitate the matter. Arbitration laws allow for notice of process through the means agreed by the parties, ${ }^{1221}$ preempting some of the burdensome methods of notice required by national legislation. For example, email could be established as a means of notice for aggregate litigation purposes in issuer-investor disputes, allowing for the development of an efficient opt-out dispute resolution mechanism. This matter will be explored further in the next chapter.

\section{Public Policy and Arbitrability of Securities Disputes}

Arbitrability is directly related to the public policy provisions of the forum. While matters that are non-arbitrable under a given legal system are matters with importance of public policy, not all matters with a public policy importance are non-arbitrable. The consumer dispute example in Brazil discussed above is a matter that falls within the non-

1217 Ibid .

${ }^{1218} \operatorname{Art} 1(2)$.

${ }^{1219}$ Art 34(2).

1220 Lith 74 (n 1134).

${ }^{1221}$ See Queensland Cotton Corporation Ltd. v Agropastoril Jotabasso Ltda. (STJ, Special Chamber, SEC 6753 / EX) (2013). For a discussion on the matter, see Born 1748-58 (n 516). 
arbitrable public policy category. An arbitral award arising out of a consumer dispute with a Brazilian customer based on a compulsory arbitration clause would not be enforceable according to Brazilian law. ${ }^{1222}$ Within the EU context, arbitrability in consumer disputes is not per se illegal, but courts do have the power to assess the unfairness of the arbitral clause according to the factual circumstances. ${ }^{1223}$ On the other hand, U.S. antitrust law, clearly a matter of public policy, falls within the arbitrable category. Previously, it was more common that any issues under national mandatory law were excluded from arbitration; this position is no longer as prevalent. ${ }^{1224}$ Some legal systems are changing, allowing public policy matters to be decided by arbitration but requiring the applicability of those laws in the arbitration procedure as a prerequisite of an enforceable award.1225 Mandatory laws embodying public policy concerns can, therefore, be arbitrable. Accordingly, it is important to establish to what extent securities laws and claims arising out of them can be submitted to arbitration.

In the U.S., securities transactions are clearly arbitrable, both in issuer-investor and the financial intermediary-investor disputes. ${ }^{1226}$ This was not always the case. In 1953, the US Supreme Court decided in Wilko v. Swan ${ }^{1227}$ that the provisions of the Federal Arbitration Act could not displace the provisions of the Securities Act of 1933 due to the language in section $\S 14$ that provided that 'any condition, stipulation, or provision binding any person acquiring any security to waive compliance with any provision of this subchapter or of the rules and regulations of the Commission shall be void.' Even though this seemed the best approach due to objectives of the Securities Act, which in part was created to protect investors and give them rights of redress, the situation was reversed in

1222 Brazilian Consumer Defense Code, art 51, VII.

1223 See Case C-168/05 Mostaza Claro v Centro Móvil [2006] ECR I-10421 (allowing the annulment of an arbitration award based on an unfair term in the consumer context, even if not pleaded in the proceedings) and Case C-40/08 Asturcom Telecomunicaciones v Cristina Rodríguez [2009] ECR I-09579 (giving the court that has to enforce an arbitral award made in the absence of the consumer, the power to assess of its own motion, whether the arbitration clause was unfair, if that is possible according to national law).

1224 Pilar Viscasilas, 'Arbitrability of (Intra-) Corporate Disputes' in Loukas A. Mistelis and Stavros L. Brekoulakis (eds), Arbitrability: International \& Comparative Perspectives (Wolters Kluwer 2009) 285.

1225 Ibid.

1226 See Ilias Bantekas, 'Arbitrability in Finance and Banking' in Loukas A. Mistelis and Stavros L. Brekoulakis (eds), Arbitrability: International \& Comparative Perspectives (Wolters Kluwer 2009) 297-300.

1227346 U.S. 427 (1953). 
Scherck v. Alberto Culver ${ }^{1228}$ and Mitsubishi v. Soler Chrysler-Plymouth Inc. ${ }^{1229}$ The first case involved the Securities and Exchange Act antifraud provision. The U.S. Supreme Court differentiated the case from Wilko v. Swan due to its international aspect, allowing arbitration in securities cases that involved disputes with parties from different countries, 1230 while the second extended this rationale to antitrust claims and consolidated the arbitrability of rights that fall within public policy. ${ }^{1231}$

In civil law countries, it is not clear whether securities disputes, especially of the investor-issuer type, are arbitrable. In Brazil, the set-up of the financial market and the existence of the Câmara de Arbitragem de Mercado, coupled with the differentiated corporate governance levels that are available in Bovespa and require arbitration of intracorporate disputes, ${ }^{1232}$ seem to indicate that securities disputes can be arbitrable. ${ }^{1233}$ The arbitration clauses in the corporate charter of the companies listed in the relevant segments indicate that disputes arising out of the rules enacted by the CVM, which regulates information disclosure and fraud, have to be solved through arbitration. ${ }^{1234}$

Therefore, even though securities laws have a relevant public policy dimension, recent developments in the field show that there might be space to soften the mandatory aspects involved, as long as the final regulatory aim of a strong market, based on some degree of investor protection, is maintained.

1228417 U.S. 506 (1974).

1229473 U.S. 614 (1985).

1230 Scherck v Alberto-Culver Co. (n. 1228) 515, 517 ('Alberto-Culver's contract to purchase the business entities belonging to Scherk was a truly international agreement. [...]The exception to the clear provisions of the Arbitration Act carved out by Wilko is simply inapposite to a case such as the one before us.')

1231 See also the discussion above on public policy and securities law.

1232 Novo Mercado, Nível 2 and Bovespa Mais.

1233 See BM\&FBOVESPA, 'O que são Segmentos de Listagem' (n 661).

1234 E.g. Estatuto Social da Abril Educação S.A., art. 49 <http://ri.abrileducacao.com.br/ptbr/governanca/Documents/Estatuto\%20consolidado_30042013.pdf> and Estatuto Social Brasil Brokers Participações S.A., art. 


\section{Public Policy and Arbitration based on Corporate Charters}

In the investor-issuer dispute, the question of the arbitrability of intra-corporation disputes is an important one. ${ }^{1235}$ Arbitration through corporate charter provisions can be a viable alternative for creating a mass dispute resolution system.

Whether arbitration based on corporate charter provisions is allowed varies greatly depending on the jurisdiction under analysis. While in Spain and in Brazil arbitration is accepted as a means of solving disputes based on corporate charters, in the United States the question still is hotly debated.

In Brazil and Spain the arbitration law is clear in allowing for arbitration agreements in corporate charters. The Brazilian Corporation Law states that:

the corporate charter may establish that the disputes between shareholders and the company, or the controlling shareholders and minority shareholders, may be solve through arbitration, within the specified terms. ${ }^{1236}$

This paragraph was added by Law 10.303/2001 in 2001, which changed relevant provisions of the Brazilian Corporate Law and of the Law 6.385/76, the law regulating the securities market and the Brazilian SEC.

The Spanish Arbitration Law has a provision of the same nature, which states that 'corporations may submit to arbitration the conflicts arising out of them.' 1237 This provision in Spanish law is new, having been added in 2011 through Law 11/2011, and enacted with the objective of modernizing arbitration in Spain. In its Preamble, it was clear the intent of the drafters was to 'clarify [...] the existing doubts related to corporate charter arbitration in corporations.' ${ }^{1238}$

In Brazil, corporate charter arbitration is not only a possibility, but it has been institutionalized through the Bovespa Listing Requirements for the two highest corporate

\footnotetext{
1235 It is true that those who have sold a security based on misleading information do not have a link to the company when the suit is brought, but nonetheless they did have a link at the moment when the sale was made.

1236 Law 6.404/76, art 109 §3.

1237, Law 60/2003, art 11 bis 1.

1238 Law 11/2011, Preamble, II.
} 
governance levels. ${ }^{1239}$ The arbitration requirement is attached to a specific arbitral institution, the Câmara de Arbitragem de Mercado. ${ }^{1240}$ Therefore, corporate charter arbitration is seen in Brazil as something better than an approach that leaves these matters to be litigated in courts. There are some criticisms to be made in respect of this current scenario in Brazil,1241 but legally, corporate charter arbitration is a possibility.

In the United States, this subject is not as simple, and despite the possibility of using corporate charter arbitration, ${ }^{1242}$ its use in public companies is a disputed matter. Resistance from various sectors, public and private, has been made since the first attempts to use arbitration clauses in corporate charters of public companies. On the public side, in 1990, a Pennsylvania Corporation tried to include arbitration clauses in its charter and bylaws, but the SEC decided to decline to accelerate the effectiveness of the company's registration statement, pushing it to exclude those provisions. ${ }^{1243}$ On the private side, the NYSE regulatory arm changed its arbitration regulation rules to ban arbitration of class and derivatives claims. ${ }^{1244}$

Despite the pro-arbitration policy in the United States, recent developments have reaffirmed the negative stance taken in respect of intra-corporate arbitration for public companies. On January 2012, the Carlyle Group was preparing an IPO and tried to include an arbitration provision in their corporate charter; ${ }^{1245}$ they were soon discouraged from

1239 See BM\&FBOVESPA, 'O que são Segmentos de Listagem' (n 661).

1240 Ibid.

1241 For example, the confidentiality surrounding the financial markets arbitration system in Brazil. See Elton Bezerra, 'Especialista critica arbitragem em mercado de capitais' (Consultor Jurídico, 30 May 2013) <http://www.conjur.com.br/2013-mai-30/arbitragem-retrocesso-mercado-capitais-professora-gv> accessed 8 July 2014.

1242 This is a discussion that has gone as far as 1988, see John C. Coffee, 'No Exit?: Opting Out, the Contractual Theory of the Corporation, and the Special Case of Remedies' (1988) 53 Brooklyn Law Review 919. At that time it already seemed that this was a path where American Law would lead to due to the preemption characteristic of the FAA (Ibid 954). See also Perry v. Thomas, 107 S. Ct. 2520 (1987).

1243 Ravanides 375 (n 507).

1244 See FINRA Customer Code, arts. 12204 and 12205.

1245 Steven Davidoff, 'Carlyle Readies an Unfriendly I.P.O. for Shareholders' (NYT Dealbook, 18 January 2012) <http://dealbook.nytimes.com/2012/01/18/carlyle-readies-an-unfriendly-i-p-o-forshareholders/> accessed 8 July 2014. 
doing so after consulting with the SEC and other interested parties. ${ }^{1246}$ It is also important to note that while the SEC and investor protection groups are fierce in combating arbitration clauses in American public companies, the same is not true for foreign companies trading in the U.S. There are many foreign companies that do have an arbitration clause in their corporate charter and are currently traded in the U.S. securities market. ${ }^{1247}$ This is interesting because foreign companies have to comply with the same requirements as American ones in order to trade their shares in the United States, and the perils that American investors might face from an arbitration clause are virtually the same, regardless of whether the companies are American or foreign. ${ }^{1248}$

In any event, this is more of a political than a legal dispute. Legally-speaking, in the American legal system, corporate arbitration has already been accepted as being possible. ${ }^{1249}$ Under this legal framework, the arbitrability of securities disputes arising out of shareholder-company relationships is a possibility, despite the resistance of the SEC in accepting these provisions in the corporate charters of American companies.

\section{Implications for Securities Disputes}

The efficiency of the law in transnational transactions depends on the mechanisms available to apply and enforce legal rules in the jurisdictions where the parties to a dispute are involved. The analysis that has to be made involves jurisdiction, the applicable law to the dispute and the possibility of recognition and enforcement of the judgment. Having identified the general aspects of private international law in the systems under analysis, I will now analyze their implications in the securities field, contributing to the response to the question posed at the beginning of this chapter.

\footnotetext{
1246 Kevin Roose, 'Carlyle Drops Arbitration Clause from I.P.O. Plans' (NYT Dealbook, 3 February 2012) <http://dealbook.nytimes.com/2012/02/03/carlyle-drops-arbitration-clause-from-i-p-o-plans/> accessed 8 July 2014.

1247 Ravanides 389-407 (n 507).

1248 Except when exemptions for cross-border offerings are applicable. See Code of Federal Regulations, $\S 230.800-230.802$.

1249 See Ravanides 414-26 (n 507).
} 
For each dispute, three questions have to be answered: 1) where can the dispute be litigated?; 2) what law is applicable?; 3) if there is the need for enforcement in another jurisdiction, can the decision be enforced?

\section{A. Investor - Issuer Disputes}

Transnational investor-issuer disputes can be categorized in the following way: if it is exchange-based, it can either be an investment from the investor in a foreign exchange or it can be made through the depositary receipt system of a foreign share in a local exchange; otherwise, it is an open-market transaction with a foreign counterparty.

\section{a. Exchange-based}

Securities that are listed on a stock exchange have a strong tie to the laws and regulations of the country in which the stock exchange is located. Listing requirements will have to be complied with, prospectus disclosure, transparency requirements and accounting information will all have to be made in accordance with what is required by that legal system. ${ }^{1250}$ As a general matter, listed securities and the obligations arising out of securities laws are governed by the law of the country in which the exchange is located, as this is considered as the relevant market for the transactions in such securities; ${ }^{1251}$ however, private international law rules may allow for a lawsuit in a different country, as well as a different applicable law regarding liability than that of the place of the exchange.

\section{Foreign Exchange}

An example can be provided. A national from country A buys securities being traded in an exchange located in country B.

As to the first question, it will normally be the case that the issuer could be sued in the courts of his domicile. Beyond domicile, the question of jurisdiction becomes more

\footnotetext{
1250 In the EU regime, the information requirements for listing and public trading of securities will be those of the place where the issuer is registered, which will then be used for listing in another country within the EU passport regime. See Wolf-Georg Ringe and Alexander Hellgardt, 'The International Dimension of Issuer Liability - Liability and Choice of Law from a Transatlantic Perspective' (2011) 31 Oxford Journal of Legal Studies 23, 30-31 and Article 17, Directive 2003/71/EC.

1251 G. Wegen and C. Lindemann, 'The Law Applicable to Public Offerings in Continental Europe' in Hans Van Houtte (ed), The Laws of Cross-Border Securities Transactions (Sweet \& Maxwell 1999) 153-59.
} 
complicated, since plenty of disagreement remains as to the characterization of damages arising out of securities fraud. ${ }^{1252}$ In the EU, there is no clear answer to the matter. Following the logic of Kronhofer v. Maier ${ }^{1253}$ the approach would be to allow for the jurisdiction of the place where the investor's account is situated as the place where the harmful event occurred; the court in this case excluded the domicile of the claimant or where his assets were concentrated for jurisdiction purposes. Another approach would be to specify the place where the damage occurred ${ }^{1254}$ as the exchange where securities are bought and sold, since this would be the place in which the first impact is felt. ${ }^{1255}$ In the U.S., under the Morrison decision, foreign issuers would hardly be subject to jurisdiction unless their securities were traded in a U.S. exchange or sold in the U.S.1256 These considerations show that investors who invest in foreign exchanges would have to engage in a foreign dispute resolution system to recover if fraud was ever perpetrated.

As to the applicable law, in the EU the logic should follow that in the Kronhofer $v$. Maier case, ${ }^{1257}$ which identifies the applicable law as that of the place of the investor's investment account, since both Brussels I and Rome II use the lex damni standard to assess jurisdiction and applicable law in tort. ${ }^{1258}$ This would cause a problem since it would subject an issuer to liability according to as many laws as there are securities owners with accounts in different jurisdictions. Instead of focusing on this approach, one which provides for the identification of the place of the exchange as the place where the damage occurred would be a better option. ${ }^{1259}$ This could be done more easily in the Rome II context than in the Brussels I due to the application of the close connection test according

\footnotetext{
1252 Ringe and Hellgardt 34 (n 1250).

1253 (n 1028).

${ }^{1254}$ As established in Case C-21/76 Bier v Mines de Potasse d'Alsace (Case C-21/76) [1976] ECR 01735.

1255 Peter Huber, Rome II regulation: Pocket Commentary (Sellier European Law Publ. 2011) 84-85.

1256 One problem would be the exact definition of 'a sale of any other security in the United States' (Morrison v National Australia Bank (n 10) 273).

1257 (n. 1028).

${ }^{1258}$ The main standard is the lex delicti for jurisdiction, but the lex damni was established for jurisdiction purposes in Mines de Potasse d'Alsace (n. 1254).

1259 This approach would guarantee one applicable law for each market, equating securities rights with the specific regulation of the market in which it is being traded. A criticism at the EU level is that, with the rules on best execution, an investor that gives an order will not know in advance which liability regime would apply to him. See Ringe and Hellgardt 53-54 (n 1250).
} 
to Article 4(3). In the U.S., applicable law would not be an issue; U.S. courts would either apply U.S. law for securities liability or would dismiss the case for failure to state a claim, not engaging in a private international law analysis due to the public policy character of the matter. ${ }^{1260}$

Following on from the first paragraph on jurisdiction, recognition and enforcement would only be an issue when the forum of the place of the exchange or where the company is registered has jurisdiction and the assets are located elsewhere. In any event, the lawsuit would by itself be a complicated one, as the investor would have to go to a foreign forum to litigate; therefore, the investor would most likely sue where the issuer's assets were available.

The overall discussion in this section demonstrates that investors who wish to invest directly in foreign exchanges are not faced with an easy enforcement regime, unless some mechanism in the foreign forum in which the issuer will be subject to jurisdiction offers such a system; this would include, for example, the class action scheme in the U.S.

\section{Depositary Receipt ${ }^{1261}$}

The example here is the following: a national from country A buys securities traded on an exchange in country A, representing securities traded in an exchange in country B. The securities are therefore in fact being anchored in country A, where the investor is situated. The courts of the investor's country therefore provide the first option for the lawsuit. The question then is whether a lawsuit in country B, where the issuer is located, will be possible. As a general matter, this would constitute a proper basis of jurisdiction, both in the EU and Brazil.1262 In the U.S., it is not completely clear what would be the case since this would deemed to be a foreign transaction, even though it is tied to an American

1260 Ibid 38-39.

1261 A depositary receipt is '[a] negotiable financial instrument issued by a bank to represent a foreign company's publicly traded securities. A depository receipt trades on a local stock exchange, but a custodian bank in the foreign country holds the actual shares. Depository receipts can be sponsored or unsponsored depending on whether the company that issued the shares enters into an agreement with the custodian bank that issues the depository receipt.' Investopedia, 'Depositary Receipt' (Investopedia) <http://www.investopedia.com/terms/d/depositaryreceipt.asp> accessed 8 July 2014.

1262 Brussels I Reg, art. 2(1); Brazilian Civil Procedure Code, art 88; for the U.S., see the discussion above in this chapter. 
issuer. In the Morrison decision, there is language suggesting that a transaction of this kind would fall outside the scope of U.S. securities laws, therefore precluding the exercise by courts of 'jurisdiction to prescribe'. ${ }^{1263}$ Another recent decision confirmed this trend, where it was decided that U.S. securities laws do not apply to transactions in foreign exchanges when the securities are cross-listed in the U.S., even if the buyer is American. ${ }^{1264}$ It seems that any transaction executed on a foreign exchange would not be subject to U.S. laws; nevertheless, it is still necessary to confirm if this is the case when the issuer is American.

As to the applicable law, even though the depositary receipt will be governed by the laws of the investor's country and at the same time, the share that it represents will be governed by the laws of the issuer's country, it is not always clear which law will apply in case the investor is harmed as a result of the issuer's fraud or misrepresentation. If the investor is suing in his country, it seems clear that his own law would apply, since the securities would be submitted to that legal system. What is not clear is what law would apply if the dispute was entertained in the issuer's forum based on a depositary receipt transacted outside of it. In the EU context, the applicable law would be the one of where the damage occurred, ${ }^{1265}$ bringing us back to the uncertainties discussed in the foreign exchange section. In the U.S., the applicability of its laws would depend on whether U.S. courts exercised jurisdiction or not, and in Brazil, there would be some uncertainty as to which law would be applicable due to the underdevelopment of its private international law; however, it is possible to envisage a convincing argument mounted on the violation of Brazilian securities laws coupled with the general liability standard.

Therefore, for securities regulation to be effective, recognition and enforcement of the judgment would be necessary, as the likely place for the dispute to be solved would be the investor's forum, under that forum's law. This would require the enforcing forum

\footnotetext{
1263 ('[...] we think that the focus of the Exchange Act is not upon the place where the deception originated, but upon purchases and sales of securities in the United States') Morrison v National Australia Bank (n 10) 266.

1264 City of Pontiac v UBS AG, No. 12-4355-cv (2 $2^{\text {nd }}$ Cir. May 2014).

1265 Rome II, art 4(1).
} 
to accept the investor's country securities laws and not to raise any public policy considerations if the company does not have sufficient assets in the investor's forum.

Another aspect that may create a difference in this analysis is whether the Depositary Receipt is sponsored, with the participation of the issuer, or unsponsored, where only the depositary bank is responsible for the securities. Unsponsored depositary receipts do not involve the issuer, but only involve financial intermediaries that coordinate the program in the foreign country. In this case, it is unlikely that the issuer will be subject to foreign securities laws, and even if it is, it is unlikely that a judgment made in such circumstances would be enforced.

\section{b. Open Market}

Securities can also be transacted outside exchanges, through direct purchase agreements on the secondary market or through public offerings. As there is no exchange tying the regulatory obligations of the transaction, the private international law analysis becomes more complicated than exchange-based ones, since different mandatory laws may be required depending on where the issuer and the buyer of securities are located and how the marketing of the securities are made.

The first question concerns where the lawsuit should be brought. In this case, the issuer's forum is an obvious choice for legal purposes, as any decision arising out of that judgment will be enforceable, even though it may consist of a great inconvenience for the investor. The investor's forum can also be a second choice, depending on the fulfillment of the requirements necessary for the court to exercise jurisdiction. ${ }^{1266}$

On the applicable law question, two approaches can be used: the law of the market in which the transaction took place and the effects test. In the first approach, the applicable law would depend on who initiated the transaction, as the law of the other party would be the applicable one since the first party 'went' to the market of the second;

\footnotetext{
${ }^{1266}$ As the requirement that the transaction occurred in the country, for a Brazilian law example, or that the forum has personal jurisdiction over defendant and is a convenient one, for a U.S. example. If an EU court were the forum of the investor and the issuer were domiciled in another Member State, jurisdiction could be established under the tort heading of the Brussels I, which gives jurisdiction to the place 'where the harmful event occurred' (art. 5(3)).
} 
in the second approach, the law of the investor would always be the applicable one.1267 of course, this would assume that the transaction would not constitute a public offering falling within the regulatory purview of the country in which the investor is situated; in this case, the transaction would be submitted to national mandatory law and subject to its liability standards. In any event, the approach to applicable law in non-exchange situations will be directly linked to the concept of the 'market' in which the transaction was executed. ${ }^{1268}$

Finally, recognition would be required in the issuer's forum if the dispute was pursued in the investor's forum; this could be complicated depending on whether the issuer's forum considers its securities laws to be mandatory and, if it does, whether it accepts a judgment, made in a foreign country, to have precedence over its public policy matters.

\section{B. Investor - Financial Intermediary Disputes}

The transnational factor in a dispute with a financial intermediary only arises if the investor is transacting with a foreign financial intermediary. The private international law analysis will depend on who took the initiative to search for the counterparty and where the transactions finally took place, as these transactions are based on contracts and regulated by the legal provisions of the place where the intermediary is located.

\section{a. Investor Acts Towards Financial Intermediary}

When the investor reaches out to a foreign financial intermediary to enter into a financial services contract, all of the transaction's aspects are strongly tied to the financial intermediary's forum, weakening the grounds to either start a lawsuit in another country or to apply the law of such country to the contract.

Under the Brussels regime and the Brazilian one for jurisdiction, this would not be possible, as there are no specific grounds for it. In the European Union regime, the place of performance of an obligation, which gives jurisdictional basis in contractual relations,

1267 Wegen and Lindemann 161-62 (n 1251).

1268 See Huber 84-85 (n 1255). In the EU, as explained above, the situation is not so clear due to the fact that the standard of the applicable law is of 'the place in which the damage occurs' (Rome II, art 4(3)). 
is deemed to be where the services are provided; in the case of financial services, this would be the place where the financial intermediary is situated. ${ }^{1269}$ In Brazil, either the obligation would have to be executed in Brazil or the fact or act be considered would have to be made in Brazil; ${ }^{1270}$ this would not be the case in a normal securities transaction since the order would be placed and executed in a foreign country. In the U.S., jurisdiction would be available only if the foreign financial intermediary had sufficient 'minimum contacts', assuming that the case would not be dismissed on the basis of forum non conveniens.

A caveat in the Brazilian system concerns whether the investor can be considered a consumer, since a consumer is any 'physical or legal person that buys or uses a product or service as the final user.'1271 If this is the case, then jurisdiction is available under Art. 101 of the Brazilian Consumer Code. The jurisprudence in Brazil is still not clear on the subject, but a recent decision has allowed choice of foreign law in a contract, recognizing a U.S. judgment and displacing Brazilian Law, even though the party resisting enforcement requested the application of the Brazilian Consumer Code. ${ }^{1272}$ Even though this was a case concerning the determination of applicable law, the logic of the analysis could also be extended for jurisdictional purposes, avoiding the jurisdictional base of the Brazilian Consumer Defense Code.

On the applicable law question, the answer would depend of the rules of the forum. In the EU, in the absence of an agreement, the applicable law would be that of the financial intermediary's forum ${ }^{1273}$ while in Brazil, it would be the law of the investor, since he would be the offeror. ${ }^{1274}$ In the U.S., with its 'most significant relationship' standard for

\footnotetext{
1269 Brussels I Reg, art 5.1(b).

1270 Brazilian Civil Procedure Code, art 88, II and III.

1271 Brazilian Consumer Defense Code, art 2.

1272 'Deveras eleito o direito aplicável à espécie em manifestação de vontade livre (GTA) referido pactum, mutadis mutandis, faz as vezes de 'compromisso' insuperável pela alegação de aplicação em contrato internacional do Código de defesa do Consumidor - CDC, lei interna, sob o argumento de que apenação inversa investiria contra a ordem pública.' General Eletric Company v Varig S.A. (STJ, Special Chamber, SEC 646 / US) (2008). In this case, it is important to note that the party resisting enforcement and asking for the application of the Brazilian Consumer Code was Varig, which was a big airline company in Brazil. The court did not appreciate this request due to the fact that this was an enforcement procedure, therefore it was prohibited from engaging the merits of the decision being enforced, even though consumer law is considered to be a matter of public order in Brazil.
}

1273 Rome I, art 4(1)(b).

1274 Decree-Law 4.657/1942, art 9. 
applicable law, the law most likely to be applied would also be the one of the financial intermediary.

As the most likely forum is the one of the financial intermediary, recognition and enforcement of foreign judgments would not be an issue in this type of case.

\section{b. Financial Intermediary Acts Towards Investor}

In the situation where the financial intermediary is the one reaching out to the investor to offer financial services, the relationship can more easily be characterized as one in which consumer regulation applies. ${ }^{1275}$

Both in the EU and in Brazil, the characterization of the investor as a consumer opens up the door of the domestic forum to solve disputes, ${ }^{1276}$ while in the U.S., this characterization is not legally relevant for the purposes of this work. It is important to note that, in the EU, if the defendant is not domiciled in another Member State, jurisdiction is established according to the jurisdiction laws of the state in which the investor is domiciled. ${ }^{1277}$

The applicable law identified will also change, becoming the one where the investor has his habitual residence, both in the EU and in Brazil,1278 even though choice is expressly allowed in the EU regime, as long as it does not deprive the investor of the protection that he would have under the otherwise applicable law. ${ }^{1279}$

Then, if the lawsuit is entertained in the investor's forum, recognition and enforcement of the decision will be necessary; this can be problematic if the financial

\footnotetext{
1275 In the EU, this is clear both in the jurisdiction and the applicable law context, as the financial intermediary would be directing his activities to the Member State where the consumer is domiciled. See Brussels I Reg, arts 15.1(c) and 6.1(b). For a more detailed analysis of the EU context, see Gralf-Peter Calliess, Rome Regulations : commentary on the European rules on the conflict of laws (Kluwer Law International ; Sold and distributed in North, Central and South America by Aspen Pub. 2011).

1276 Brussels I Reg, art 16 and Brazilian Consumer Defense Code, art 101.

1277 Brussels I Reg, arts 4 and 15(1).

1278 Rome I, art 6(1).

${ }^{1279}$ Rome I, Article 6(2).
} 
intermediary's forum does not recognize the decision of the investor's forum or if there was a choice-of-forum or arbitration provision that was not respected.

\section{Investor - Informational Intermediary Disputes}

In this scenario, the investor would act based on information provided by a foreign informational intermediary. As there is no direct link between investors and informational intermediaries, such as credit rating agencies and accounting firms, the private international law analysis is based on tort standards.

Jurisdiction can be commonly established where the defendant is domiciled, but sometimes also where the harmful event occurred. In the EU context, the harmful event can be understood to be the place, both where event giving rise to it was perpetrated and also where the damage arose, ${ }^{1280}$ which in this situation, would imply the relevant securities market. ${ }^{1281}$ In Brazil, it would not be possible to raise a lawsuit against a foreign informational intermediary due to the lack of proper jurisdictional basis. In the U.S., even though jurisdiction could be based on the effects that the act caused, ${ }^{1282}$ it would most likely not survive a minimum contacts test. ${ }^{1283}$

The applicable law question in the $\mathrm{EU}$ is a complicated one, as the standard is where the 'damage occurs', 1284 giving rise to different possibilities such as the place where the assets were located just before the transfer or the branch of the bank where the account is held. ${ }^{1285}$ In this case though, the most likely result is the use of the 'closest connection' escape clause ${ }^{1286}$ and the application of the law of the market for which the rating was intended. In Brazil, the applicable law would be the one of the information intermediary since in the Brazilian private international law system, the applicable law is

1280 See Case C-51/97 Réunion Européennee SA v Spliethoff's Becrachtingskantoor BV [1998] ECR I-6534, para 28.

1281 What exactly the relevant market is has not been made clear under EU Law.

1282 See Restatement (Second) of Conflict of Laws $§ 37$ ('A state has a natural interest in the effects of an act within its territory even though the act itself was done elsewhere').

1283 International Shoe Co. v. Washington 326 US 310 (1945).

1284 Rome II, art 4(1).

1285 See Dickinson, The Rome II Regulation: the law applicable to non-contractual obligations 327-30 (n 1174); Huber 76-83 (n 1255).

1286 Rome II, Art 4(3). 
the one of the place where the obligation was constituted. As Brazil could only be the forum if it were the source of the tort, in such case Brazilian law would be the only one applicable.

Recognition and enforcement may be necessary when the informational intermediary is sued outside its jurisdiction. Public policy could play a role if the jurisdiction that has to enforce the judgment finds that the forum country either had no jurisdiction or that the applicable law is against its public policy.

\section{Final Considerations on the Transnational Aspects of Securities}

\section{Disputes}

This chapter has shown that the transnational infrastructure for dispute resolution in securities transactions stands on weak ground. Not only might the investor face problems in solving a securities dispute in his own country, he may also encounter problems regarding the law that would be applicable to his transaction.

The lack of clear guidance in EU private international law in respect of securities transactions and pure economic loss situations, the discretionary aspect of the American system of private international law, and the under development of the Brazilian private international law system poses clear problems of legal certainty for investors wishing to invest in foreign markets. In these situations, the safest approach is litigation in the place where the defendant is situated, which is an unrealistic proposition for small and medium retail investors.

The objective of this discussion is not investor protection per se, as the capital markets regimes analyzed in this work do present a strong level of investor protection for the national market, but rather the task of making it easier for a foreign investor to be protected by foreign regimes, opening up the possibility of reliance in cross-border transactions.

If this is accomplished, capital markets will find a road paved for foreign investor confidence, opening up the possibility for stronger integration without losing the regulatory safeguards that national jurisdictions have developed in order to protect their investors from foreign predatory practices. The next chapter proposes possible solutions. 


\section{Chapter XI - Building a Transnational Securities Dispute Resolution System}

I started this thesis with the following research question:

'How can the legal infrastructure for transnational securities transactions disputes be improved?'

In Chapter II, the basis of the state and its development throughout the years has been explained, as well as the basic economic role of the legal system within the state structure, which comprises the role of serving as a background for the organization of economic activity and the instrumental role of correcting market failures. In Chapter III and IV, the importance of securities regulation as a mechanism to diminish transaction costs via the provision of reliable information to investors, has been established, and the significance of the role of private enforcement as a mechanism to enforce securities regulation and promote the goals of market efficiency has been set out. From these chapters, it has become clear that dispute resolution is the mechanism through which private enforcement can be deployed to guarantee compliance with securities regulation rules and to promote the confidence of investors, who will be able to rely on the information that is being provided in securities markets (an important consideration to avoid the self-destruction of the market through the logic of the lemons problem).1287

Chapter V is where the transnational problems of securities disputes has begun to take place. The comparison of different liability systems for securities transactions shows that, despite the fact that the duties owed to investors follow the same broad lines (disclosure of information and protection from predatory practices), the specific aspects of liability can vary considerably.

In Chapter VI, I have outlined the main institutional aspects surrounding a dispute resolution system, underlining the necessary aspects for access and the operation of the Rule of Law principle, providing some examples of alternative models in Chapter VII.

${ }^{1287}$ Akerlof (n 181). 
Due to the role that aggregate litigation can play in access to justice, Chapter VIII has been concerned with the problematic aspects of this mechanism of dispute resolution, such as conflicts of interest, due process and the operation of preclusion, while in Chapter IX some aggregate litigation systems have been explained.

Finally, in Chapter X the core transnational problems of securities disputes have been established and analyzed, providing the necessary overview for identifying and understanding the main issues in transnational securities disputes.

As securities markets become transnational, it is important that legal structures for dispute resolution of securities transactions are also created to deal with securities transactions involving transnational elements. This in turn will ease the enforcement of securities regulation principles and guarantee that market participants can effectively rely on a legal solution for their disputes. Access to justice, therefore, is an important background for the development of strong transnational securities markets.

Due to the different securities regulation systems that exist today and the inadequacy of private international law to bring legal certainty for securities transactions, in this last chapter I briefly restate the problems with the current framework for each type of securities dispute (section 1) and then propose a solution to each of them (sections 2 and 3).

For mass disputes, namely, those of an investor-issuer and investor-informational intermediary type, I propose an arbitration model to allow for aggregate litigation and to ease the structuring of the dispute resolution system, while at the same time diminishing most of the transaction problems that arise out of cross-border litigation. For the investor-financial intermediary disputes, I propose a network model based on Fin-Net rescaled to the global environment, providing adequate information for foreign investors, therefore increasing access.

\section{Problems with Transnational Dispute Resolution of Securities Transactions}

Securities are regulated because they tap into the savings pool of the general population, creating the need to avoid inequitable practices. Transnationally, there are 
two questions that are important - first, is there a legal infrastructure available to solve the dispute, and second, is it accessible?

\section{A. The Legal Infrastructure for Securities Dispute Resolution}

Any country that has a legal system will most likely have a dispute resolution system that will be able to deal locally with securities transactions; the range of different dispute resolution systems is broad and depends on policy choices made in each particular jurisdiction. ${ }^{1288}$

In any developed legal system there will be a forum for securities disputes, but what is not given is if the country will have links with other legal systems to enforce a decision that is rendered by one of its courts. From the investor perspective, the transnational problems arises when (a) the investor purchases a security of a foreign company or a security listed in a foreign country, (b) the intermediary is based in a foreign country and finally (c) the investor relies on a rating or an audit of a foreign informational intermediary.

Private international law is the area that deals with these problems, and, as explained above, there is no simple solution to it, as various different approaches exist, depending on the country that will enforce the judgment. The question here is one of jurisdiction over the defendant and enforceability of the decision where the defendant has his assets.

Matters of jurisdiction, as well as of the enforceability of foreign decisions, are country-specific and will vary depending on the public policy choices of a given country. For the transnational system to work, the forum of the investor will have to be able to exercise jurisdiction over a foreign defendant on terms that are acceptable to the foreign forum, otherwise enforceability will be at stake. ${ }^{1289}$ Alternatively, the foreign system

\footnotetext{
1288 For example, the FINRA arbitration forum that was developed through self-regulation mechanisms and industry practice, and the alternative dispute resolution mechanisms in Europe, encouraged by MIFID Directive, art 53.

1289 Richard Fentiman frames this problem as 'Enforcement Risk', explaining that its absence is what allows for the dispute to proceed. Richard Fentiman, International Commercial Litigation (Oxford University Press 2010) 691.
} 
needs to provide alternatives so that outside investors can obtain redress; this then becomes a problem of access.

In other words, either there are bridges available to connect the different legal systems, allowing for a decision in one system to travel and be enforced in another, or the investor has available access to the foreign system.

\section{B. Access to a Dispute Resolution System}

Access, nationally or transnationally, is a basic problem of dispute resolution; if the investor is harmed, the costs and incentives should be adequate to allow the investor to pursue his claim. There are two paths that can be used to solve the problem, as has been explained throughout the previous chapters: low costs for access to the dispute resolution system or aggregate litigation mechanisms. Each of these paths has their advantages and disadvantages.

While with low costs, any person can decide whether to pursue his claim, the incentives might not be high enough for them to start the lawsuit, either due to the small advantages that may accrue from it or to the complexity of the claim. ${ }^{1290}$ On the other hand, with aggregate litigation a lawyer or an investor with a more substantial stake in the dispute may take the lead of the lawsuit; a single set of facts common to all of the investors is necessary for the aggregate litigation system to work. Also, a system that binds those who are absent from the lawsuit is not common and can be complicated to implement in countries that are not familiar with the system. When the discussion moves to the transnational sphere, the question then becomes one of the availability of dispute resolution mechanisms that can effectively solve the dispute, while at the same time maintaining adequate access.

1290 This is an economic question - the more complex the claim is, the more expensive it will be to litigate. For a brief overview on how to calculate the value of a claim, see Robert Cooter and Thomas Ulen, Law \& Economics (Pearson Education 2014) 388-91. 


\section{Dispute Resolution Systems in Transnational Securities Transactions - Institutional Considerations}

Each set of disputes arising out of transnational securities transactions has their own particular characteristics and problems; as such, a one-size-fits-all approach to them would be inadequate. In Chapter V, three types of disputes in securities transactions were identified: investor - issuer, investor - financial intermediary and lastly, investor informational intermediary. The different institutional frameworks for dispute resolution will be considered according to the particular characteristics of these different disputes.

\section{A. Investor - Issuer}

The investor-issuer dispute involves multiple investors that were harmed due to an omission or false statement made in connection with the purchase of securities. The factual pattern for the persons that were harmed in these types of cases is similar, as it arises out of the same information that has been given to the market.

Even though a dispute resolution mechanism that functions on an individual basis can be used for this type of dispute, aggregate litigation could enhance the incentives for litigation, as the amount at stake for the dispute would be increased, creating the possibility for third parties to assume coordination costs. ${ }^{1291}$ Aggregate litigation would also lower the aggregate social costs for solving a single dispute with many claimants, as fewer judicial procedures would be necessary to solve all of the disputes arising out of the same factual pattern. ${ }^{1292}$ For the type of dispute at stake, the use of an arbitration framework may be adequate to avoid the prohibitions on aggregate litigation and guarantee enforceability at the transnational level.

\section{a. Setting the Incentives}

For aggregate litigation to work, a party has to be able to increase the stake of the litigation by aggregating the claims of other parties and to benefit from it, enhancing the

1291 John C. Coffee, 'Understanding the Plaintiff's Attorney: the Implications of Economic Theory for Private Enforcement of Law Through Class and Derivative Actions' (1986) 86 Columbia Law Review 669, 679.

1292 Layton 93 (n 700). 
personal profit that can be achieved by doing so. ${ }^{1293}$ Any aggregation mechanism that does not take this economic logic into account is prone to failure since there would be no positive outcomes for a person to pursue this line of action otherwise.

It does not matter who that person will be; a claimant, a lawyer or a third-party funder can function as the litigation manager, assuming the risks of failure and some of the profits of litigation. ${ }^{1294}$ This principle works both in simple aggregate litigation and class action-style mechanisms; the important aspect is that there should be additional advantages for the party who will be managing the claimant side of litigation so there is an economic reason to sue, while at the same time, aligning their incentives with claimants. ${ }^{1295}$

In the absence of opt-out mechanisms, and given the fact that lawyers are suitable candidates for this leading position in aggregate litigation, rules on maintenance, champerty and solicitation, which can be identified across different jurisdictions, have to be softened for aggregate litigation to become a suitable mechanism for the resolution of mass disputes. ${ }^{1296}$ At the same time, in order to avoid abuses perpetrated by the bar, mechanisms should also be developed to make lawyers accountable, so that frivolous lawsuits can be avoided. ${ }^{1297}$

1293 This is important to solve the free-rider and other collective action problems, especially when the harm is too small for a single person to pursue it. Macey and Miller 8-9 (n 742); See generally Olson (n 705).

1294 For a discussion on the lawyer as the litigation manager, see Macey and Miller. For a discussion on thirdparty financiers as the litigation manager, see Burch, 'Financiers as Monitors in Aggregate Litigation' Molot (n 727).

1295 In these situations, the other side of the coin is that defendants may reach out to the plaintiff's lawyers to settle at a price that is below the 'fair value' of the claim (see Hensler and Rowe 138 (n 731)). Here the solution would be to set limits on the fee that the lawyer can obtain, linking it to a maximum percentage of the outcome for claimants.

1296 Due to the needs of economies of scale for litigation to be economically feasible, lawyers would have to be able to market and line up a multitude of claimants with small claims. For a discussion on maintenance and champerty, see Sebok (n 750). For other problems that professional ethics rules may bring, see Charles Silver, 'Ethics and Innovation’ (2011) 79 George Washington Law Review 754.

1297 For example, in cases in which lawyers take the lead of the litigation, a fee-shifting provision making the lawyer liable for any loss could be an option. For a discussion in the class action context, see Hensler and Rowe 152-59 (n 731). 


\section{b. Overcoming the Prohibition of Opt-Out Aggregate Litigation}

Opt-out aggregate litigation, with preclusion operating to all of those that would have a claim arising out of the same factual pattern, is a device that exists only in certain jurisdictions.

Its advantage is that it creates a single lawsuit that definitely solves all the claims arising out of the same facts, putting an end to the dispute and avoiding the need for the defendant to defend itself from the same case over and over again, thus diminishing litigation costs. In addition, by allowing the aggregation of all possible claims, it increases the incentive for the matter to be litigated when contingent fee schemes are allowed. At the same time, due to its size, it is also in danger of becoming a bet-the-company type of dispute, since a decision against the defendant may destroy the company financially as well as its reputation; some argue that it can become a form of legalized blackmail. ${ }^{1298}$ In any event, if a liability rule can create too much harm for the defendant, the substantive rule is the one that should be reformulated, not those shaping access to justice.

As the opt-out system can be an interesting alternative to solve disputes regarding issuer-investor claims, the prohibitions on it have to be overcome; this can be done through the use of arbitration. 1299

Operationally, this can be done by including an arbitration clause in the corporate charter of the issuer, obliging all investors to solve any disputes with the company through arbitration. ${ }^{1300}$ This excludes the judicial forum as an alternative for dispute resolution, but it also provides for alternative procedural rules that can be more flexible than those in national civil procedural codes, such as rules regarding notice and service of process. ${ }^{1301}$

\footnotetext{
1298 Analyzing the claim that class actions are legalized blackmails, see Charles Silver, '"We're Scared to Death": Class Certification and Blackmail' (2003) 78 New York University Law Review 1357.

1299 Despite the problems that class arbitration may encounter outside of the U.S., a legal structure can be imagined where an 'opt-out' procedure based on arbitration is developed. For a discussion on these problems in Europe, see Billiet (n 1025).

1300 See generally Ravanides (n 507).

${ }^{1301}$ See Born 1742-44 (n 516).
} 
The main problem for the enforceability of the decision, public policy considerations on the character of securities disputes apart, would be due process concerns regarding notice to each and every possible claimant. ${ }^{1302}$ With this problem in mind, it is possible to devise a scheme which provides that when litigation ensues, the issuer becomes obliged to notify every investor of the lawsuit, allowing them to join or be represented by the lead claimant, thus making them aware that a dispute resolution procedure is being initiated and that they will be bound by it, and guaranteeing due process standards and a fair trial. With the information technology available today, this should not be much of a problem, as notice could easily be given by email.

\section{c. Transnational Aspects}

In addition to allowing easier means of notification, arbitration also facilitates the resolution of problems arising out of the transnational character of the transaction. As soon as the arbitration becomes international, the framework of the New York Convention can be used for the enforcement of foreign arbitral awards.

As long as the arbitral tribunal's jurisdiction can be established by the existence of a proper arbitration clause within the corporate charter, it is unlikely that there will be issues on the recognition and enforcement of a foreign arbitral award. To avoid the need for recognizing and enforcing the award, the system could even be set up in a way so that the arbitration would have its seat where the decision has to be enforced. This would work as long as the legal system in which the seat would be located would have a pro arbitration regime operating at least to the same extent as the rules of the New York Convention.

The only problem that may exist concerns the public order character of securities rules. If national legal systems provide that securities regulation is a public policy matter arising out of their own securities regulation regime, they may deny recognition and enforcement of arbitral decisions.

${ }^{1302}$ Under the New York Convention, one of the grounds for non-enforcement of an arbitral award is lack of notice of the proceedings (art. V(1)(b)). This also is a basis under national legislation (see Uncitral Model Law on International Commercial Arbitration (2006), art 36(1)(a)(ii)). 


\section{d. System Design and Rule of Law}

Due to the public policy character of securities regulation and the necessity of information for investors to assess their risks in these transactions, including legal risks, it is highly important that the system operates within the parameters of the Rule of Law principle.

All those aspects that have been addressed in Chapter VI in respect of the legal dimension of the institutional aspects, have to be included in this system. Independence and accountability of the decision-maker and reasoned decisions that are made public are paramount to the success and efficacy of the system in providing for a serious alternative for courts that could be used for transnational transactions.

The absence of reasoned decisions, or their confidentiality, can harm the legal certainty of the system, as it would be impossible to know where the law stands at any given moment. This is the case of Brazil today, which has an arbitration system designed for companies listed at the higher corporate governance levels, creating a paradox since those companies, which should exercise the best practices of corporate governance and provision of information to the market, hide behind the veil of arbitration in case of disputes with shareholders. A solution to this would be to oblige arbitration systems that deal with disputes between investors and public companies to publish their decisions; this could be done through industry self-regulation or legislation. Arbitral decisions would then have a de facto precedential value for future disputes.

\section{e. Implementation Aspects}

An important question concerns how such a system could become reality. Companies may prefer litigation regimes that make it harder for investors to obtain redress, so the chances of being sued and having a harmful financial setback from litigation is diminished. As it is the company that would have to decide to include an arbitration regime in its corporate charter, it seems unlikely that this would be done without any other incentive.

A path for an arbitration system for issuer-investor disputes might engage the use of different corporate governance levels when the company is listed, to encourage its use. 
In Brazil, for example, the companies listed at higher corporate governance levels are obliged to have an arbitration clause in their corporate charter. ${ }^{1303}$

With the globalization of capital markets, this would provide an interesting way to use the existing legal infrastructure already available throughout the world to promote a level playing field for the investors of a given company, regardless of where they are from. It would then be easier for the company to tap foreign markets, as the rights attached to the shares, including procedural ones, would be uniform across countries, thus avoiding some of the problems that arose in foreign cubed securities class actions in the United States where foreign plaintiffs were not able to pursue litigation in U.S. courts due to their foreign status. ${ }^{1304}$

For the company, this would imply a higher level of transparency, since actual rights from share ownership would vary less, and possibly attract a higher valuation due to it. ${ }^{1305}$ It would be important for securities exchanges to create differentiated corporate governance levels with arbitration and opt-out dispute resolution mechanisms, and to market them as such so as to make investors aware of the characteristics of these systems.

\section{B. Investor - Financial Intermediary}

An ideal dispute resolution system would give investors easy access to justice, allowing them to pursue their claims from any country in which they are situated, against any financial intermediary with whom they have transacted; this would be done under rules that they can comprehend and can manage without causing themselves serious harm for minor mistakes.

Regarding access, contrary to the investor-issuer dispute, the investor-financial intermediary dispute is one in which the fact pattern is highly individual. The determination of what the financial intermediary did or said to the investor is what will

1303 Novo Mercado, Nível 2 and Bovespa Mais. See BM\&FBOVESPA, 'O que são Segmentos de Listagem' (n 661).

1304 This implies that the securities will not be completely subject to the foreign regime, for example, by being listed in the foreign country. The application of this regime will be explained further below.

${ }^{1305}$ For a discussion on the effects of transparency when coupled with good governance, seeLifeng Gu and Dirk Hackbarth, 'Governance and Equity Prices: Does Transparency Matters? ' [2013] 2013 Review of Finance 1. 
be of most significance in this type of dispute, forbidding the use of aggregate litigation as a mechanism to solve it. ${ }^{1306}$

The problem of access can therefore only be solved by using alternative procedural mechanisms or alternative dispute resolution systems, such as the small claims court in Brazil or the Financial Ombudsman Service in the U.K. By having low or non-existent access costs and allowing a party to proceed without a lawyer, these systems enable any person to engage in a dispute if he deems the financial loss to be sufficiently relevant to be worthwhile. The forum could even be an online platform, where the investors would fill out a form with their claims and arguments, making access to the system extremely easy. ${ }^{1307}$

The question that then arises concerns how these mechanisms would be structured when transnational transactions are involved, as in most countries there already is some type of alternative dispute resolution system that addresses these concerns.

\section{a. Transnational Aspects}

The transnational aspect in financial intermediary - investor disputes becomes complicated because most countries have strong regulations to protect investors and to regulate investment services. Securities regulation and civil liability arising out of noncompliance is specific to the legal system and can have important differences.

There are two situations in which a transnational dispute may arise between an investor and a financial intermediary: firstly, when the investor wants to invest in a foreign country and seeks a financial intermediary of that country which can provide

\footnotetext{
1306 For example, in Europe there are plenty of cases involving the demise of Lehman Brothers against financial intermediaries that were selling products based on Lehman Brothers' credit risk. To illustrate some of these disputes in the UK, see the decisions of the Financial Ombudsman Service DRN 1570597, DRN 191087 and DRN 3824818 (denying the investor's claim) and DRN 3727359 and DRN 2604832 (upholding the complaint); in Spain, see Tribunal Supremo Sentencia n. 244/2013 (RJ 2013/3387), AP Madrid (Sección 20a), sentencia n. 427/2013 (AC 2014/156).

${ }^{1307}$ Such as what has been proposed in the consumer context in Europe through the ODR Regulation, where the online 'platform should take the form of an interactive website offering a single point of entry to consumers and traders seeking to resolve disputes out-of-court', 'allow[ing] consumers and traders to submit complaints by filling in an electronic complaint form' (Regulation (EU) 524/2013, recital 18).
} 
services to allow him to invest there, and secondly, when the financial intermediary reaches out to an investor in a foreign country.

In the first case, the investor will hardly be able to bring the financial intermediary to his own forum. If the financial intermediary has no contacts with the country of the investor, there will be no basis for the investor's forum to exercise jurisdiction over the defendant, and even if it does, the decision would still have to be recognized in the financial intermediary's forum. The option then is for the investor to sue in the financial intermediary's forum, which may be complicated due to costs and lack of information regarding the legal system, as well as from possible language barriers.

In the second case, when the financial intermediary is the one reaching out to the investor, the regulatory regime of the investor's forum comes into play, and so does the dispute resolution mechanisms that exist there. In any event, in case the financial intermediary loses the case and decides not to pay, the investor would still have to recognize the judgment where the financial intermediary has assets.

As a result of the differences in securities regulation regimes and liability standards, it is important for an investor to have easy access to a dispute resolution system that can bind and allows for the enforcement of a decision against the financial intermediary.

An overarching dispute resolution system at an international level that could solve this type of dispute is unlikely; its implementation would be extremely difficult due to the costs involved and the idiosyncrasies of each legal system.

In the absence of a treaty on securities regulation rules that could in fact harmonize the regulation of investment services and create an international court to solve disputes arising from them, the best approach to dispute resolution would be to engage the local dispute resolution bodies to create a mechanism that would facilitate foreign investor access. Some ways in which this can be done would be through information disclosure and the use of easy procedures for dispute settlement, for example by using the internet for the submission of claims and maybe even as a means to conduct hearings. 
This is advantageous both to the investor, who will have a forum that will be able to deal properly with the issue, and for the market that offers these services to foreign investors, which will be seen as an attractive venue for investment.

The language barrier may be an issue, and realistically no single system will be able to deal with all the languages of different investors. While this could be a problem, an investor would probably not invest in a place where the language is completely unknown to him. A solution that could diminish the problem would be for the dispute resolution system to offer the possibility of conducting the procedure in English, which is a language known widely in the financial industry. Another possibility is to offer cheap translation services for those who need it.

Therefore, the idea is, following the model of the European approach, to develop a network of dispute resolution systems in charge of forwarding investors, involved in investor-financial intermediary disputes, to the appropriate dispute resolution bodies.

It is true that this solution is based on the premise that the alternative dispute resolution bodies will be adequate and able to provide easy access to investors; this might not always be the case.

\section{b. Implementation Aspects}

For this system to be effective, two steps need to be satisfied. The first is to guarantee that the dispute resolution systems that will be part of the network have the ability to definitively solve the disputes between investor and financial intermediaries, in addition to giving adequate protection to the industries it is supposed to operate. ${ }^{1308}$

Its legal aspect depends on the binding nature of the decision being issued by the system; otherwise, the system is nothing more than a conciliation forum. It does not matter that the body is based on direct or consent jurisdiction. Systems based on consent jurisdiction, where the granting of decision-making power is based on the consent of the parties, are preferable because they can rely on the arbitration framework and take

1308 In the Fin-Net context, there have been some problems with national ADRs schemes that were not comprehensive enough to provide investors with alternative forums, undermining access to justice and consequently, investor protection. See Moloney, How to protect investors: lessons from the EC and the UK 455-58 (n 372). 
advantage of the New York Convention regime. A locally-based arbitration system mandatory to industry members that may allow foreign investors to opt-in after a dispute has arisen would be an interesting option, as it would solve many transnational questions, provide an alternative forum for the investor while at the same time, protect due process; the forum would be accessible only by the investor's acceptance after the dispute was ripe, weakening the investor's argument of lack of due process in his own forum afterwards if there is no success in the arbitration procedure. ${ }^{1309}$

Moreover, the preconditions for the operation of the Rule of Law principle are also important; the schemes should guarantee independent decision-makers and publish reasoned decisions so that the legal system can evolve, bringing legal certainty to its users.

As soon as legally binding dispute resolution systems are in place, the second step is for the network to develop. This has to be done through discussions and agreements between the different systems. The development is a political one that will need the input of industry members, both from the investor and financial intermediary sides. 1310

\section{Investor - Informational Intermediary}

The usual case in which an informational intermediary harms an investor occurs where the information provided is based on false or misleading representations. For example, when a Credit Rating Agency rates a bond as a triple-A, even though the company is on the verge of bankruptcy, and relying on the information provided by the CRA, the investor buys the security.

The relationship between investor and informational intermediary is, for most of the time, inexistent, as the rating is created to inform the general market and not a specific investor. There is no contract or corporate link between the parties. The same is true for information prepared by auditors, as the investor who relies on it has no direct legal

\footnotetext{
${ }^{1309}$ This design, conceptually, would not be pure arbitration, as it would require the use of both pure and consent jurisdictional bases. A pure arbitration basis could also be imagined, but this would require the will of the industry to accept such a mechanism, which is unlikely.

${ }^{1310}$ For a 2009 discussion on the development of Fin-Net, see DG Internal Market and Services, Evaluation of FIN-NET (Final Report June, 2009); European Commission, Summary of the Responses to the Public Consultation on Alternative Dispute Resolution in the Area of Financial Services (September, 2009).
} 
relationship with them, unless the auditor has been hired by the investor to do due diligence on the company, which is not usually the case in public market transactions.

This creates an extremely hard-to-solve scenario for a comprehensive and investor-friendly dispute resolution mechanism. As there is no direct contact between the informational intermediary and the investor, the only forum available would be the courts of the place in which the informational intermediary is located. The courts of the place in which the investor is located would be an option where it is allowed by the forum state, but enforcement would be extremely hard due to requirements of proper notice and the acceptance of the exercise of exorbitant jurisdiction by foreign courts in these cases.

As to the extent of the harm caused, this situation is similar to the one where the investor purchases securities based on information provided by the issuer. False or misleading information provided by informational intermediaries can be harmful to a whole collectivity, having far-reaching effects to all of those who have transacted based on such information. Aggregate litigation could therefore be an option to solve the dispute.

Another problem concerns the scope for different applicable laws to the transaction at stake, as different countries have different approaches to the liability of informational intermediaries. For example, while the U.S. is lenient in its approach, Australia has a tighter grip on the standard of care that informational intermediaries owe to the market. From the investor's perspective, the applicability of Australian law would be more interesting when there is an Australian aspect involved in the transaction, but the only certainty of its applicability would be when the Credit Rating Agency is also Australian.

One way to facilitate the venue and access issue would be to have credit rating or auditing contracts, when so requested by the company issuing the securities, imposing an obligation on the informational intermediaries to accept arbitration on the same parameters as the system proposed for investor-issuer disputes; this would allow for aggregate litigation, which would connect the CRAs to the dispute resolution scheme put in place by the investor.

To solve the applicable law question, a provision could be added to the contract between informational intermediaries and issuers, identifying the law applicable to any disputes arising out of their relationship and their relationship with third parties; in 
addition, a clause should also be included in the corporate charter of the company issuing securities, identifying a law that would also apply to that relationship, creating an indirect legal link between investor and informational intermediary.

Informational intermediaries would most likely oppose this proposition, as it would increase the risk of their business. Therefore, for such a system to be implemented, pressure would have to come from the companies using their services, which in turn would imply powerful investors pressuring the companies to do so. An alternative method could be introduced through the imposition of regulation by regulatory agencies; this would be more complicated to implement at the transnational level due to the local reach of regulatory systems.

\section{Two Systems for Transnational Dispute Resolution of Securities}

\section{Transactions}

The question with which I started this thesis was "how can the legal infrastructure for transnational securities transactions disputes be improved?'

The ideal solution would be an overarching system, an international court, composed only of specialist judges and providing easy access for any investor that had been harmed. This court would have compulsory jurisdiction, where any securities disputes with a transnational character would be solved. Of course, this solution is not feasible due to the costs and political constraints of creating such a system, in addition to the regulatory diversity that is present in securities regulation today. Nonetheless, dispute resolution systems for transnational securities transactions could be socially beneficial, as they would strengthen cross-border confidence in different markets, increasing the incentives to invest in a foreign jurisdiction.

Starting from the current landscape, there are paths that can be used to build a better transnational legal infrastructure. Private international law problems are tied to questions of jurisdiction, applicable law and enforcement; they can become quite complex depending on the situation at hand, especially when the public policy aspects of the jurisdiction in which a decision has to be enforced come into play. 
Moreover, private international law problems can be more or less prevalent depending on the dispute at stake; cross-listed companies will be subject to at least two regulatory systems, and may have investors from even more jurisdictions. Another regulatory system would also apply if there were any selling efforts that could have been seen as directed towards other jurisdiction, thus engaging an extra set of liability rules to be managed. On the other hand, financial intermediaries will only be subject to foreign law in the case that they are the ones pursuing the investor outside of the jurisdiction in which they are licensed to work, otherwise they will be regulated safely within the confines of their own jurisdiction, even if the investor is a foreigner.

In the previous section, I outlined the main aspects of how different dispute resolution systems could be improved depending on the type of dispute at stake, discussing the parties' incentives for litigation, the transnational aspects at stake and the incentives for implementation. In this section, I outline how these systems can be legally operationalized. As discussed throughout this work, within the broad topic of 'transnational dispute resolution of securities transactions', there are two areas of disputes that have different problems and require different solutions, for which I propose (A) aggregate litigation through arbitration for the mass type of disputes and (B) a network of ADRs for financial intermediary disputes.

\section{A. Aggregate Litigation Through Arbitration}

The mass type of dispute involving many investors from different jurisdictions, who have been harmed as a result of information provided by relevant market actors, needs a better solution for access and for centralization of the dispute resolution process, to avoid litigation in too many different jurisdictions and the costs that come with multiple proceedings. The proposal advanced is the use of arbitration with an aggregate dispute resolution mechanism; this solves the problem as it centralizes the dispute in a single forum, and to a certain extent also avoids some of the private international law issues such as enforcement and applicable law. This can work both for the investor-issuer and the investor-informational intermediary type of dispute, as outlined previously in this chapter. The main aspects regarding the legal operationalization of the system are related to (A) the seat of arbitration; (B) arbitration clauses; (C) importance of the arbitral institution; and (D) possible problems remaining. 


\section{a. Seat of Arbitration and Arbitrability}

The arbitral seat is the 'home' of the arbitration, having important consequences to the legal framework under which the arbitration will fall. ${ }^{1311}$ These consequences include the national law applicable to the arbitral procedure, the law applicable to the relationship with national courts and their power to annul the award, the law applicable to the validity of the agreement, and the definition of the place where the award is 'made', amongst other issues. ${ }^{1312}$

The objective of the system is twofold: (a) to increase access to investors, including foreign ones and (b) to provide an efficient mechanism that guarantees that the issuer will not have to engage in many different dispute resolution procedures for a dispute involving a single set of facts. The choice of the seat is closely related to the second issue.

Efficiency, for these purposes, can be translated in a legal framework that allows for innovation in arbitration, since the proposal will include an opt-out aggregate litigation mechanism that is functionally similar to the American class action, while at the same time guarantees, to the highest extent possible, that the award will be enforceable in other countries. Liberal national legislation and a status as part of the New York Convention and other international arbitration regimes, is an important aspect that has to be taken into consideration when making the choice. This is a prerequisite for this idea to work.

The second important aspect is that the arbitral seat must be closely connected with the place in which the issuer has assets, where the issuer is incorporated or where the issuer is listed. The best scenario would be if all three places where the same, anchoring the issuer to a single national jurisdiction.

From the issuer's perspective, this is important because if the assets are located in a jurisdiction that considers securities matters non-arbitrable, investors may sidestep the arbitration agreement contained in the charter and sue directly in the courts of such a place, defeating the purpose of the arrangement. The same is true regarding the place in

1311 Gary Born, International Commercial Arbitration (2nd edn, Wolters Kluwer Law \& Business 2014) 1538. 1312 Ibid 2053. 
which the company is incorporated and where it is listed. If it is incorporated in one jurisdiction, listed in another and has most of its assets in a third, the issuer must verify if all three jurisdictions would accept the use of arbitration for securities disputes, which would increase legal risk and due diligence costs for the company.

The limitations are clear: the issuer must be anchored in a jurisdiction with a proarbitration mentality to be able to deploy a comprehensive dispute resolution system for arbitration disputes.

\section{b. Arbitration Clauses}

The second important aspect to the operation of a global dispute resolution system for securities transactions based on arbitration are well drafted arbitral clauses within the relevant documents. The foundational arbitration clause regulating the dispute resolution procedure between investors and issuer is to be found in the corporate charter of the issuer. Additional clauses could also be included in the services contract between issuer and informational intermediary so as to make them part of the dispute resolution process in case they can also be held liable under substantive law for their acts. Finally, if the issuer uses Depositary Receipts mechanisms to reach other markets, an arbitration clause should also be included in the Depositary Agreement. I provide clauses that could be used to construct such a system below.

\section{Corporate Charter Clause}

The corporate charter clause has to address the main aspects of the dispute resolution mechanism, including who will be bound by the clause, the subject matter of the dispute, the applicable law governing the subject matter and procedure of the arbitration, the arbitral institution that will manage it and its adequate rules, the language and the seat of arbitration. In addition, since this will be a new development in the field, specific due process guarantees should also be articulated in the clause. The proposal here is a combination of personal notice through email and the publication of the beginning of the arbitration procedure in major newspapers.

\section{Dispute Resolution and Applicable Law}

a. The Corporation, its shareholders and former shareholders, directors, executives and any other party engaging in contractual relations with the 
Corporation with a clause in their contract referring to this arbitration clause, agree to finally solve all disputes, claims, controversies and disagreements relating or arising out of the Corporate Law and Securities Law provisions governing this Corporation and the transaction of its securities, by arbitration. a.1. The laws of (Jurisdiction) shall be applicable to the substantive matters of any disputes, claims, controversies or disagreements related to this clause as well as to the submission to arbitration and the arbitral proceedings.

a.2. The arbitration shall be administered by (Arbitral Institution), the Rules of which (Specify the Rules) are deemed to be incorporated by reference into this clause.

a.3. The language to be used in the arbitral proceedings shall be (Specify the Language).

a.4. The place of arbitration shall be (City/Country).

b. To guarantee due process, notification shall be provided to every party included in the arbitration procedure by any means that can effectively inform them, including but not limited to emails, which will be regarded as the main method of communication.

b.1. Each shareholder, beneficiary or of record, shall inform the issuer of an email address to which notice under this arbitration procedure shall be given. b.2. In aggregate proceedings, notice by email together with the publication on three different occasions within two weeks, of notice in a major newspaper of the country in which the arbitration will take place, shall be considered sufficient to include any interested party in the arbitration proceeding.

\section{Informational Intermediary Services Contract Clause}

To bind the informational intermediary to the aggregate arbitration procedure, an arbitration clause in the contract between the issuer and the informational intermediary is necessary. It is important to note that Credit Rating Agencies issuing ratings that are not requested by the issuer will never be included in the arbitration procedure, as there will be no link capable of bringing them to arbitration.

\section{Dispute Resolution}


Any dispute arising out of or in connection with this contract, including third parties relying on the information provided by the Informational Intermediary, shall be referred to and finally resolved by arbitration in accordance with the Dispute Resolution and Applicable Law clause provided in the Corporate Charter of the Issuer.

\section{Depositary Agreement Clause}

In cases in which the issuer enters foreign markets through the use of Depositary Receipts, an arbitration clause should also be included in the Depositary Agreement. One interesting example is the Baidu and Bank of New York agreement, which provides for arbitration 'in the event the Depositary is advised that a judgment of a court in the United States may not be recognized'.1313 In the proposed dispute resolution system, a more straightforward arbitration clause referring to the corporate charter of the issuer is preferred.

\section{Dispute Resolution}

Any dispute arising out of or in connection with this Deposit Agreement shall be referred to and finally resolved by arbitration in accordance with the Dispute Resolution and Applicable Law clause provided in the Corporate Charter of the Issuer.

\section{c. Importance of the Arbitral Institution}

Arbitral institutions do not decide the cases themselves, but they serve as case managers, guaranteeing the integrity of the arbitral procedure. ${ }^{1314}$ In the particular discussion on aggregate litigation, the arbitral institution will also need to have rules that are adequate for the arbitration procedure and expertise on dealing with such matters, as they may become complicated.

1313 Deposit Agreement between Baidu.com, Inc., The Bank of New York and Owners and Beneficial Owners of American Depositary Receipts 28 <http://www.sec.gov/Archives/edgar/data/1329099/000119312505140785/dex43.htm>. 1314 Born, International Commercial Arbitration 171 (n 1311). 
Important issues that need to be outlined in advance with clear rules are the minimum threshold of claimants that could start the aggregate arbitration procedure, the mechanism to select the lead claimant, the notice procedure and the mechanism to choose arbitrators. Furthermore, another interesting aspect, related to the incentives of the parties that could be included in the rules, is a fee-shifting provision, to avoid unmeritorious claims and to compensate the defendant, at least to a certain extent, if an unmeritorious claim is nevertheless arbitrated.

Below I provide language for institutional rules to deal with these four issues.

\section{Aggregate Arbitration Procedure}

a. Minimum Threshold. Any person having at least $10 \%$ of a stake in the dispute may initiate an aggregate arbitration (Initial Claimant) procedure by giving notice to the Arbitral Institution and against whom a claim is being made (Respondent) of the request for aggregate arbitration.

i. Respondent will have 10 days to respond the request for aggregate arbitration.

ii. The Arbitral Institution, after analyzing the request and the response to the request for aggregate arbitration, will decide if the procedure is adequate for the dispute.

b. Notice and Opt-out. If the Arbitral Institution decides that the aggregate arbitration procedure is adequate, the Initial Claimant will give notice to any other persons who may be part of the dispute ('Other Claimants').

i. In case respondent has the information regarding any Other Claimants, Respondent shall be obliged to provide the information to the Initial Claimant.

ii. Notice shall be given by email or any other written means, such as mail. Only those duly notified will be bound by the arbitration procedure.

iii. Any Other Claimant who does not wish to participate in the aggregate proceeding may opt-out of it by informing the Arbitral Institution in writing, having 60 days from the decision establishing the Lead Claimant to do so. 
c. Lead Claimant. Any claimant or group of claimants may apply to be Lead Claimant in the arbitration procedure, who will then be responsible for steering the claimant side of the arbitration procedure, hiring lawyers and exercising any other actions in the interest of all claimants.

i. The selection of Lead Claimant shall be made by the Arbitral Institution according to the amount the applicant or group of applicants has at stake in the dispute.

ii. In case the selected Lead Claimant is different from the Initial Claimant, the Lead Claimant shall reimburse any costs incurred by Initial Claimant in giving notice to other claimants.

d. Arbitration Costs and Attorney's Fees. The party that loses the arbitration shall pay the other party's costs and attorney's fees.

i. Each party shall deposit in an escrow account the amount established in Annex I for Arbitration Costs and Attorney's Fees at the beginning of the Arbitration Procedure.

ii. The Initial Claimant shall be responsible for the initial deposit, and may be reimbursed in case a different claimant is appointed as Lead Claimant.

iii. Only the Lead Claimant shall be responsible for Arbitration Costs and Attorney's Fees, but in case the claims are upheld the Lead Claimant will also be the only one to be reimbursed.

\section{d. Possible Problems Remaining}

The proposed scheme solves the problem of access of small investors while at the same time, discourages unmeritorious suits, protecting issuers from nuisance litigation. Even though this scheme can provide an interesting option in respect of the current landscape, there are still some problems that may arise in the transnational realm due to the public policy aspect of securities laws.

Assuming that the system is duly established in a jurisdiction that accepts the arbitrability of securities disputes, the problem of foreign investors suing overseas will still be present, as long as those investors are under a jurisdiction that does not accept the arbitrability of securities disputes. This is not a problem as long as the issuer has no assets or can otherwise be forced to comply with that jurisdiction's decision. 
Another question that comes to mind concerns the case that arises if this problem emerges in the context of the EU. How can a duly performed arbitration, that is recognized by the state where the issuer is situated, stand in face of a contrary decision of another Member State's court in a procedure for enforcement, in the issuer's state, under Brussels I? The problem that arises is that arbitration is not covered by Brussels I; even a court decision on the validity of the arbitration agreement in the issuer's forum would most likely not be covered by Brussels I, due to the wide exclusion that the ECJ accepted in Marc Rich \& Co AG v. Società Italiana Impianti. ${ }^{1315}$ This puts the arbitral award, and the court denying recognition of the foreign decision, in an awkward situation: under national law, the arbitral award has preclusion effects, but since the arbitration is excluded from Brussels I, the recognizing court is not able to rely on art. 34(3) but is left only with the public policy exception of 34(1).

In any event, the aggregate arbitration mechanism proposed here can at least solve the access problem faced by foreign investors who do not have the money or energy to engage in this type of litigation, as it enrolls another claimant with a bigger stake to do so for all those who potentially have a valid claim. As the claimants who will benefit from the mechanism would be unlikely to sue, the procedural legal problems discussed here would not in fact pose such a threat to the company that adopts it.

\section{B. A Network of ADRs}

The investor-financial intermediary type of dispute requires a different solution due to the personal character of the relationship. A mass procedure would not be adequate, and the question of access still remains open. The investor should have an easy path to solve the dispute; a dispute resolution body that would hear his complaint, notify the financial intermediary and give a binding decision.

As most countries already have alternative dispute resolution systems for these disputes, and they usually do not involve complex private international law questions, the best approach would be to engage the national dispute resolution bodies in a network so they can cooperate with one another and point the investor to the appropriate body that

1315 Case C-190/89 Marc Rich \& Co AG v. Società Italiana Impianti PA, [1991] ECR I-3855. 
could deal with the dispute. The premise here is that these bodies need to offer easy access to the investor, solving the disputes fairly and according to Rule of Law standards. The Fin-Net system in Europe could be used as a model to create a global network that could deal with these cases.

To operationalize such a system there is not much that can be done legally, absent a full treaty creating a world-wide arbitral institution or court to deal with such cases, which would obviously be complicated to enact. Agreements between dispute resolution bodies would rather provide the best approach to coordinate and create mechanisms for disputes involving foreign investors.

One shortcoming of this system would arise in those cases in which the financial intermediary approaches the foreign investor in his jurisdiction, while not having a presence there. This can be a problem when the investor's law is more beneficial than the financial intermediary's, as the ADR body would not be familiar with it and might not be willing to apply such rules. The option left would be either for the investor to sue in the foreign court and try to enforce the judgment in the financial intermediary's forum, which is what I have been trying to avoid throughout this work, or for the investor to accept the less favorable approach in exchange for a possible forum to solve the dispute.

An argument could also be made for arbitration in these situations, but due to the consensual character of the procedure and the limits imposed by investor and consumer protections laws, this approach would not be without serious problems. In addition, financial intermediaries searching for retail foreign investors without establishing a presence in the country, are likely to be acting illegally and not in good faith; their acceptance to include an arbitration clause with a fair mechanism of dispute resolution is unlikely, leaving the investor with his own court or the ADR of the place in which the financial intermediary is established.

A network of ADRs could at least facilitate access, providing a higher level of protection for retail investors, consequently increasing the confidence in foreign investments made with foreign financial intermediaries. 


\section{Final Considerations}

Throughout these pages, I have tried to show that private enforcement is an important mechanism for the application of securities laws and the construction of confidence on capital markets, which can be considered a prerequisite for its full development.

Despite the globalization of capital flows, the strength of the legal infrastructure for the protection of small and medium investors who may participate, willingly or not, in transactions with transnational elements is low due to the strong national character of legal systems and securities regulations; this raises a variety of problems related to access to justice and legal uncertainty generated by public policy conflicts and the operation of private international law.

The objective of this work was not to respond to the question of whether or not it is a good idea to involve small and medium investors in transnational securities transactions; however, to the extent that various investors have come to find themselves involved in such investments and the global securities market has also started to develop in this direction, it becomes important to provide alternatives that could solve, or at least diminish, the legal problems surrounding transnational dispute resolution, increasing access to justice and diminishing legal uncertainty. This is especially true in places where the transnational aspect of securities transactions is becoming more and more prevalent due to the quest for market integration, such as in the EU.

The legal infrastructure for resolving transnational disputes therefore comes to form a crucial background to enable a higher degree of market integration, since more people would be able to rely on it and develop confidence in the system. As demonstrated in this final chapter, arbitration and institutional cooperation can go a long way to achieve these objectives for the development of truly global capital markets. 


\section{Bibliography}

'Estrutura $\quad$ Remuneratória $\quad$ Cargos Efetivos' (TJMS) <http://www.tjms.jus.br/transparencia/resolucao102/anexo3 estrutura remuneratori a.php $>$ accessed 8 July 2014

'Information for Businesses Covered by the Ombudsman Service' (Financial Ombudsman Service)

$<$ http://www.financialombudsman.org.uk/faq/businesses/answers/rules a8.html> accessed 8 July 2014

'Quem Somos' (Banco BM\&FBOVESPA) $<$ http://www.bmfbovespa.com.br/bancobmfbovespa/institucional.asp $>$ accessed 8 July 2014

'Regulatory Reform - Background' (Financial Services Authority) <http://www.fsa.gov.uk/about/what/reg reform/background> accessed 8 July 2014

'Securities Commission' (West Virginia State Auditor's Office) <https://www.wvsao.gov/securitiescommission/history.aspx> accessed 7 July 2014

'Status of the Convention on the Recognition and Enforcement of Foreign Arbitral Awards' (Uncitral)

<http://www.uncitral.org/uncitral/en/uncitral texts/arbitration/NYConvention status.

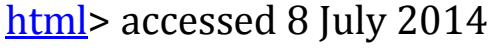

'Annual Review 2012/2013' (Financial Ombudsman Service, 1 April 2012 to 31 March 2013) <http://www.financial-ombudsman.org.uk/publications/ar13/dealt.html> accessed 8 July 2014

'Our Plans and Budget for 2013/2014 - Finalised and Approved' (Financial Ombudsman Service, $20 \quad$ March 2013) < http://www.financialombudsman.org.uk/news/updates/plan and budget 13-14.html> accessed 8 July 2014

'Our Plans and Budget for 2012/2013 - Finalised and Approved' (Financial Ombudsman Service, 27 March 2012) <http://www.financialombudsman.org.uk/news/updates/planandbudget-2012-13-approved.html> accessed 8 July 2014

Aguiar AS, "The Law Applicable to International Trade Transactions with Brazilian Parties: a Comparative Study of the Brazilian Law, the CISG, and the American Law about Contract Formation' (LLM, University of Toronto 2011)

Akerlof GA, 'The Market for "Lemons": Quality Uncertainty and the Market Mechanism' (1970) 84 The Quarterly Journal of Economics 488

Al-Shawaf HT, 'Bargaining for Salvation: How Alternative Auditor Liability Regimes can Save the Capital Markets' [2012] 2012 University of Illinois Law Review 502 
Albert J, Study on the Transparency of Costs of Civil Judicial Proceedings in the European Union - Final Report - Annex 48 - Spain (2007)

Alloway T, 'The Lehman flip-clause flap gets settled - sort of' (FT Alphaville, 27 July 2011) <http://ftalphaville.ft.com/2011/07/27/634976/the-lehman-flip-clause-flap-getssettled-sort-of/> accessed 7 July 2014

Alter K, 'The European Court's Political Power Across Time and Space' (2009) Northwestern Law \& Econ Research Paper No 09-03 1

Analysis BoE, 'International Investment Position of the United States at Yearend, 1976$2010^{\prime}$ < http://www.bea.gov/international/xls/intinv10 t2.xls > accessed 07 July 2014

Andreotti T, "The Legitimacy and Accountability of the IASB as an International Standard Setter' in Cafaggi F and Miller G (eds), Private Regulation and Enforcement in Financial Institutions (Edward Elgar 2013)

Andrews N, 'Multi-Party Proceedings in England: representative and group actions' (2001) 11 Duke Journal of Comparative \& International Law 249

Armour J, Hansmann $\mathrm{H}$ and Kraakman R, 'Agency Problems and Legal Strategies' in Kraakman $\mathrm{R}$ and others (eds), The Anatomy of Corporate Law: a comparative and functional approach (2nd edn, Oxford University Press 2009)

Arnett GW, Global Securities Markets: Navigating the World's Exchanges and OTC Markets (John Wiley \& Sons, Inc. 2011)

Aroca JM and others, Derecho Jurisdiccional II - Proceso Civil (Tirant Lo Blanch 2004)

Ásgeirsson H, 'Integration of European Securities Markets' [2004] 2004 Monetary Bulletin - The Central Bank of Iceland 50

Ashenfelter 0 and Iyengar R (eds), Economics of Commercial Arbitration and Dispute Resolution (Edward Elgar 2009)

Atiyah PS, The Rise and Fall of Freedom of Contract (Clarendon Press 1979)

Baker J, 'From Lovedays to ADR: Arbitration and Dispute Resolution in England 10661800’ [2006] 2006 Transnational Dispute Management 1

Baldwin R, Cave M and Lodge M, Understanding Regulation: Theory, Strategy, and Practice (2nd edn, Oxford University Press 2012)

Bank W, Institutional Foundations for Financial Markets (2006)

Banner S, 'What Causes New Securities Regulation? 300 Years of Evidence' (1997) Washington University Law Quarterly 849

Bantekas I, 'Arbitrability in Finance and Banking' in Mistelis LA and Brekoulakis SL (eds), Arbitrability: International \& Comparative Perspectives (Wolters Kluwer 2009)

Bariatti S, Cases and materials on EU private international law (Hart Pub. 2011) 
Barkow RE, 'Insulating Agencies: avoiding capture through institutional desing' (2010) 89 Texas Law Review 15

Bassett DL, 'Constructing Class Action Reality' 2006 Brigham Young University Law Review 1415

Baumgartner S, 'Understanding the Obstacles to the Recognition and Enforcement of U.S. Judgments Abroad' (2013) 45 New York University Journal of International Law \& Politics 965

Becker GS and Stigler GJ, 'Law Enforcement, Malfeasance, and Compensation of Enforcers' (1974) 3 Journal of Legal Studies 1

Benston GJ, 'The Value of the SEC's Accounting Disclosure Requirements' (1969) 44 The Accounting Review 515

Berg AJvd, The New York Arbitration Convention of 1958 (Kluwer Law and Taxation 1981)

Bernstein L, 'Opting Out of the Legal System: Extralegal Contractual Relations in the Diamond Industry' (1992) 21 Journal of Legal Studies 115

---, 'Private Commercial Law in the Cotton Industry: Creating Cooperation through Rules, Norms, and Institutions' (2000-2001) 99 Michigan Law Review 1724

Bezerra E, 'Especialista critica arbitragem em mercado de capitais' (Consultor Jurídico, 30 May 2013) <http://www.conjur.com.br/2013-mai-30/arbitragem-retrocesso-mercadocapitais-professora-gv> accessed 8 July 2014

Billiet P (ed) Class Arbitration in the European Union (Maklu 2013)

Billiet P and Lozano L, 'General Reflections on the Recognition and Enforcement of Foreign Class Arbitral Awards in Europe' in Billiet P (ed), Class Arbitration in the European Union (Maklu 2013)

Bingham T, The Rule of Law (Allen Lane 2010)

BM\&FBOVESPA, 'Câmara de Arbitragem do Mercado' (BM\&FBOVESPA) <http://www.camaradomercado.com.br/> accessed 8 July 2014

---, 'O que são Segmentos de Listagem' (BM\&FBOVESPA) $<$ http://www.bmfbovespa.com.br/pt-br/servicos/solucoes-para-empresas/segmentosde-listagem/o-que-sao-segmentos-de-listagem.aspx?Idioma=pt-br> accessed 8 July 2014

Bó ED, 'Regulatory Capture: a review' (2006) 22 Oxford Review of Economic Policy 203

Bone RG and Evans DS, 'Class Certification and the Substantive Merits' (2001-2002) 51 Duke Law Journal 1521

Borkowski A, Borkowski's Textbook on Roman Law (Oxford University Press 2010)

Born G, International Commercial Arbitration (Kluwer Law International 2009)

---, International Commercial Arbitration (2nd edn, Wolters Kluwer Law \& Business 2014) 
Brasil BCd, 'Série Histórica da Posição Internacional de Investimento' <http://www.bcb.gov.br/?SERIEPIIH> accessed 07 July 2014

Brazil-David R, 'An Examination of the Law and Practice of International Commercial Arbitration in Brazil' (2011) 27 Arbitration International 57

Brickey KF, 'Andersen's Fall from Grace' (2003) 81 Washington University Law Quarterly 917

Brownsword R, 'The Theoretical Foundations of European Private Law: a time to stand and stare' in Brownsword R and others (eds), The Foundations of European Private Law (Hart Publishing 2011)

Buckner CJ, 'Due Process in Class Arbitration' (2006) 58 Florida Law Review 185

Buell S, 'What is Securities Fraud?' (2011) 61 Duke Law Journal 511

Bundesbank D, Securities Market Regulation: International Approaches (Monthly Report January, 2006)

Burbank SB, 'Jurisdiction to Adjudicate: End of the Century or Beginning of the Millennium?' (1999) 7 Tulane Journal of International and Comparative Law 111

---, 'Jurisdictional Conflict and Jurisdictional Equilibration: Paths to a Via Media?' (2004) 26 Houston Journal of International Law 385

---, 'The Class Action Fairness Act of 2005 in Historical Context: a preliminary view' (2008) 156 University of Pennsylvania Law Review 1439

Burch EC, 'Procedural Justice in Nonclass Aggregation' (2009) 44 Wake Forest Law Review 1

---, 'Litigating Together: social, moral, and legal obligations' (2011) 91 Boston University Law Review 87

---, 'Financiers as Monitors in Aggregate Litigation' (2012) 87 New York University Law Review 1273

Burk J, 'The Origins of Federal Securities Regulation: A Case Study in the Social Control of Finance' (1985) 63 Social Forces 1010

Busch D, 'Why MiFID Matter to Private Law - the example of MiFID's impact on an asset manager's civil liability' (2012) 7 Capital Markets Law Journal 386

Buxbaum HL, 'Multinantional Class Actions Under Federal Securities Law: Managing Jurisdictional Conflict' (2007-2008) 46 Columbia Journal of Transnational Law 14

---, 'National Jurisdiction and Global Business Networks' (2010) 17 Indiana Journal of Global Legal Studies 165

Cable V, 'The Diminished Nation-State: a Study in the Loss of Economic Power' (1995) 124 Daedalus 23 
Cafaggi F, 'Rethinking Private Regulation in the European Regulatory Space' (2006) 2006 EUI Working Papers 13

Calamari J and Perillo J, The Law of Contracts (4th edn, West Group 1998)

Calixto N and Marins VAAB, 'Eficácia da Sentença e Coisa Julgada Perante Terceiros' (1989) 25 Revista da Faculdade de Direito da UFPR 93

Calliess G-P, Rome Regulations : commentary on the European rules on the conflict of laws (Kluwer Law International ; Sold and distributed in North, Central and South America by Aspen Pub. 2011)

Carbonell F, 'Reasoning by Consequences: Applying Different Argumentation Structures to the Analysis of Consequentialist Reasoning in Judicial Decisions' in Dahlman C and Feteris E (eds), Legal Argumentation Theory: Cross-Disciplinary Perspectives, vol 102 (Springer 2013)

Carneiro RL, 'A Theory of the Origin of the State: Traditional Theories of State Origins are Considered and Rejected in Favor of a New Ecological Hypothesis' in Hall JA (ed), The State: Critical Concepts, vol I (Routlegde 1994)

Cassidy J, How Markets Fail: the Logic of Economic Calamities (Farrar, Straus and Giroux 2009)

Cavanagh ED, 'Issue Preclusion in Complex Litigation' (2009-2010) 29 The Review of Litigation 859

Chalmers D, Davies G and Monti G, European Union Law (2nd edn, Cambridge University Press 2010)

Chasin ACdM, 'Uma Simples Formalidade: estudo sobre a experiência dos Juizados Especiais Cíveis em São Paulo’ (LLM, USP 2007)

Cherednychenko 0, 'European Securities Regulation, Private Law and the Investment Firm-Client Relationship' [2009] European Review of Private Law 925

Chiapello E and Medjad K, 'An Unprecedent Privatisation of Mandatory Standard-Setting: the Case of European Accounting Policy' (2009) 20 Critical Perspectives on Accounting 448

Chisholm AM, An Introduction to International Capital Markets (2nd edn, John Wiley \& Sons 2009)

Chiu IHY, Regulatory convergence in EU securities regulation (Kluwer Law International 2008)

Choi SJ, 'Do the Merits Matter Less After the Private Securities Litigation Reform Act?' (2006) 23 The Journal of Law, Economics, \& Organization 598

Choi SJ, Fisch JE and Pritchard AC, 'Do Institutions Matter? The Impact of the Lead Plaintiff Provision of the Private Securities Litigation Reform Act' (2005) 83 Washington University Law Quarterly 869 
Choi SJ and Thompson RB, 'Securities Litigation and its Lawyers: Changes During the First Decade After PSLRA' 06-26 NYU Law and Economics Research Paper Series 1

Clarkson CMV and Hill J, The Conflict of Laws (4 edn, Oxford University Press 2011)

Co. M, Sustaining New York's and the U.S.' Global Financial Services Leadership (22 January 2007)

Coffee JC, 'Rescuing the Private Attorney General: Why the Model of the Lawyer as a Bounty Hunter is not Working' (1983) 42 Maryland Law Review 215

---, 'Market Failure and the Economic Case for a Mandatory Disclosure System' (1984) 70 Virginia Law Review 717

---, 'Understanding the Plaintiff's Attorney: the Implications of Economic Theory for Private Enforcement of Law Through Class and Derivative Actions' (1986) 86 Columbia Law Review 669

---, 'The Regulation of Entrepeneurial Litigation: Balancing Fairness and Efficiency in the Large Class Action' (1987) 54 University of Chicago Law Review 877

---, 'No Exit?: Opting Out, the Contractual Theory of the Corporation, and the Special Case of Remedies' (1988) 53 Brooklyn Law Review 919

---, 'Class Wars: the Dillemma of the Mass Tort Class Action' (1995) 95 Columbia Law Review 1351

---, 'Class Action Accountability: Reconciling Exit, Voice and Loyalty in Representative Litigation' (2000) 100 Columbia Law Review 370

---, 'Class Action Accountability: Reconciling Exit, Voice and Loyalty in Representative Litigation' 100 Columbia Law Review

---, 'What Caused Enron? A Capsule Social and Economic History of the 1990s' (20032004) 89 Cornell Law Review 269

---, 'Law and the Market: the Impact of Enforcement' (2007) 156 University of Pennsylvania Law Review 229

Coglianese C and Mendelson E, 'Meta-Regulation and Self-Regulation' in Baldwin R, Cave $\mathrm{M}$ and Lodge M (eds), The Oxford Handbook of Regulation (Oxford University Press 2010)

Commission E, Summary of the Responses to the Public Consultation on Alternative Dispute Resolution in the Area of Financial Services (September, 2009)

Commission TFCI, The Financial Crisis Inquiry Report (2011)

Cooter R and Ulen T, Law and Economics (5th edn, Pearson Addison Wesley 2008)

,--- Law \& Economics (Pearson Education 2014)

Cooter RD and Rubinfeld DL, 'Economic Analysis of Legal Disputes and Their Resolution' (1989) XXVII Journal of Economic Literature 1067 
Cornes R and Sandler T, The Theory of Externalities, Public Goods and Club Goods (Cambridge University Press 1996)

Couture WG, 'Mixed Statements: the Safe Harbor's Rocky Shore' (2011) 39 Securities Regulation Law Journal 257

Craig P and Búrca GD, EU law text, cases, and materials (Oxford University Press 2011)

Crawford B, "The Hague "Prima" Convention: Choice of Law to Govern Recognition of Dispositions of Book-Based Securities in Cross Border Transactions' (2003) 38 Canada Business Law Review 157

Cunningham GM and Harris JE, 'Enron and Arthur Andersen: the Case of the Crooked E and Fallen A' (2006) 3 Global Perspectives on Accounting Education 27

CVM, 'The Commission' (CVM) <http://www.cvm.gov.br/ingl/indexing.asp $>$ accessed 7 July 2014

David TR, Corley JP and Delawalla AA, 'Heightened Pleading Requirements, Due Diligence, Reliance, Loss Causation, and Truth-on-the-Market - Available Defenses to Claims under Sections 11 and 12 of the Securities Act of 1933' (2009) 11 Transactions Tennessee Journal of Business Law 53

Davidoff S, 'Carlyle Readies an Unfriendly I.P.O. for Shareholders' (NYT Dealbook, 18 January 2012) <http://dealbook.nytimes.com/2012/01/18/carlyle-readies-anunfriendly-i-p-o-for-shareholders/> accessed 8 July 2014

Davies M, 'Time to Change the Federal Forum Non Conveniens Analysis' (2002) 77 Tulane Law Review 309

Davies PL, 'Enron and Corporate Law Reform in the UK and the European Community' in Hopt KJ and others (eds), Corporate Governance in Context: Corporations, States and Markets in Europe, Japan, and the US (Oxford University Press 2005)

Demsetz H, 'Towards a Theory of Property Rights' (1967) 57 American Economic Review, Papers and Proceedings 347

Diamond D and Verrecchia R, 'Disclosure, Liquidity, and the Cost of Capital' (1991) 46 The Journal of Finance 1325

Dicey, Morris and Collins, The Conflict of Laws (15 edn, Sweet and Maxwell 2012)

Dicey AV, The Law of the Constitution (Oxford University Press 2013)

Dickinson A, 'European Private International Law: Embracing New Horizons or Mourning the Past?' (2005) 1 Journal of Private International Law 197

---, The Rome II Regulation: the law applicable to non-contractual obligations (Oxford University Press 2008)

Dinamarco CR, 'Relativizar a Coisa Julgada Material' (2001) 55/56 Revista da Procuradoria Geral do Estado de São Paulo 25 
Doherty JW, Reville RT and Zakaras L (eds), Confidentiality, Transparency, and the U.S. Civil Justice System (Oxford University Press 2012)

Doidge C, Karolyi GA and Stulz RM, 'Why are Foreign Firms Listed in the U.S. Worth More?' (2004) 71 Journal of Financial Economics 205

Donovan D and Greenawalt A, 'Mitsubishi after Twenty Years: Mandatory Rules Before Courts and International Arbitrators' in Mistelis L and Dew J (eds), Pervasive Problems in International Arbitration (Kluwer Law International 2006)

Drahozal CR, 'Federal Arbitration Act Preemption' (2004) 79 Indiana Law Journal 393

Easterbrook FH, 'Substance and Due Process' [1982] 1982 The Supreme Court Review 85

Easterbrook FH and Fischel DR, 'Mandatory Disclosure and the Protection of Investors' (1984) 70 Virginia Law Review 669

El-Agraa A, 'The Theory of Economic Integration' in El-Agraa A (ed), The European Union: Economics and Policies (9th edn, Cambridge University Press 2011)

Ellis N, Fairchild L and D'Souza F, 'Is Imposing Liability on Credit Ratings Agencies a Good Idea?: Credit Rating Agency Reform in the Aftermath of the Global Financial Crisis' (20112012) 17 Stanford Journal of Law, Business and Finance 175

Epstein RA (ed) Economics of Property Law (Edward Elgar 2007)

Erichson H, 'Beyond the Class Action: lawyer loyalty and client autonomy in non-class collective representation' [2003] 2003 University of Chicago Legal Forum 519

ESMA, Report: Comparison of Liability Regimes in Member States in Relation to the Prospectus Directive (2013)

España Bd, Boletín Estadístico 12/2012 (2013)

Fairgrieve D and Howells G, 'Collective Redress Procedures: European Debates' in Fairgrieve D and Lein E (eds), Extraterritoriality and Collective Redress (Oxford University Press 2012)

Fama EF, 'Efficient Capital Markets: a Review of Theory and Empirical Work' (1970) 25 The Journal of Finance 383

Feintman R, 'Recognition, Enforcement and Collective Judgments' in Nuyts A and Hatzimihail NE (eds), Cross-Border Class Actions: The European Way (Seillier European Law Publishers 2014)

Fentiman R, International Commercial Litigation (Oxford University Press 2010)

Ferejohn JA and Kramer LD, 'Independent Judges, Dependent Judiciary: Institutionalizing Judicial Restraing' (2002) 77 New York University Law Review 962

Field BC, 'The Evolution of Property Rights' (1989) 42 Kyklos 319

Finance PRIME, 'About Us

' (P.R.I.M.E. Finance) < http://primefinancedisputes.org/about-us/> accessed 8 July 2014 
FINRA, 'About Finra' (Financial Industry Regulatory Authority) <http://www.finra.org/AboutFINRA/> accessed 8 July 2014

---, 'FINRA's Arbitrators' (FINRA)

<http://www.finra.org/ArbitrationAndMediation/Arbitrators/BecomeanArbitrator/FI

NRAArbitrators/index.htm> accessed 8 July 2014

---, 'Optional All Public Panel Rules' (FINRA)

<http://www.finra.org/ArbitrationAndMediation/Arbitration/Rules/NoticestoArbitrat

orsParties/NoticestoParties/P123997> accessed 8 July 2014

---, NASD and NYSE Member Regulation Combine to Form the Financial Industry Regulatory Authority - FINRA (2007)

Fleckner AM, 'FASB and IASB: Dependence Despite Independence' (2008) 3 Virginia Law \& Business Review 275

Flesher DL, Previts GJ and Samson WD, 'Auditing in the United States: a Historical perspective' (2005) 41 Abacus 21

Ford T, 'The History and Development of Old Rule 23 and the Development of Amended Rule 23' (1966) 32 Antitrust Law Journal 254

Fox EM, 'Modernization of Effects Jurisdiction: from hands-off to hands-linked' (2009) 42 International Law and Politics 159

Fox MB, 'Demystifying Causation in Fraud-on-the-Market Actions' (2005) 60 The Business Lawyer 507

Fox MB and others, 'Law, Share Price Accuracy, and Economic Performance: the New Evidence' (2003) 102 Michigan Law Review 331

Frank R, Microeconomics and Behavior (McGraw-Hill Irwin 2010)

Fukuyama F, State-Building: Governance and World Order in the 21st Century (Cornell University Press 2004)

Fund IM, 'The Liberalization and Management of Capital Flows: an Institutional View' (2012)

Galbraith JK, The Great Crash: 1929 (Houghton Mifflin Company 1997)

Garner BA, Black's Law Dictionary (West Publishing Co. 2004)

---, Black's Law Dictionary (West Publishing Co. 2009)

Gaspari E, A Ditadura Envergonhada, vol 1 (Companhia das Letras 2002)

---, A Ditadura Escancarada, vol 2 (Companhia das Letras 2002)

---, A Ditadura Derrotada, vol 3 (Companhia das Letras 2003)

---, A Ditadura Encurralada, vol 4 (Companhia das Letras 2004) 
Georgosouli A, 'The Debate over the Economic Rationale for Investor Protection Regulation: a Critical Appraisal' (2007) 15 Journal of Financial Regulation and Compliance 236

Gidi A, 'Class Actions in Brazil: a Model for Civil Law Countries' (2003) 51 The American Journal of Comparative Law 311

Gilles M and Friedman GB, 'Exploding the Class Action Agency Costs Myth: the Social Utility of Entrepreneurial Lawyers' (2006-2007) 155 University of Pennsylvania Law Review 103

Gillies L, 'Creation of Subsidiary Jurisdiciton Rules in the Recast of Brussels I: Back to the Drawing Board?' (2012) 8 Journal of Private International Law 489

Gilson RJ and Kraakman R, 'The Mechanisms of Market Efficiency Twenty Years Later: The Hindsight Bias' 446 Harvard Law School John M Olin Center for Law, Economics and Business Discussion Paper Series 1

Gilson RJ and Kraakman RH, 'The Mechanisms of Market Efficiency' (1984) 70 Virginia Law Review 549

Glover JM, 'Beyond Unconscionability: Class Action Waivers and Mandatory Arbitration Agreements' (2006) 59 Vanderbilt Law Review 1735

Goetz CJ and Scott RE, 'Enforcing Promises: an examination of the basis of contract' (1980) 89 Yale Law Journal 1261

Gonçalves CR, Direito Civil Brasileiro, Volume IV: Responsabilidade Civil (Editora Saraiva 2009)

Gonçalves MVR, Direito Processual Civil Esquematizado (Editora Saraiva 2012)

Gordon JN and Kornhauser LA, 'Efficient Markets, Costly Information, and Securities Research' (1985) 60 New York University Law Journal 761

Grigoleit HC, 'Mandatory Law: Fundamental Principles' in Basedow J, Hopt K and Zimmermann R (eds), Max Planck Encyclopaedia of European Private Law (Oxford University Press 2011)

Gross JI, 'The End of Mandatory Securities Arbitration?' (2010) 30 Pace Law Review 1174

Grossman S and Stiglitz J, 'On the Impossibility of Informationally Efficient Markets' (1980) 70 The American Economic Review 393

Grossman SJ and Hart OD, 'Disclosure Laws and Takeover Bids' (1980) 35 The Journal of Finance 323

Group RDW, A Matter of Trust: how the revolving door undermines public confidence in government - and what to do about it (2005)

Grundmann S, 'The Bankinter Case on MIFID Regulation and Contract Law' (2013) 9 European Review of Contract Law 267 
Gu L and Hackbarth D, 'Governance and Equity Prices: Does Transparency Matters?' [2013] 2013 Review of Finance 1

Guedj TG, 'The Theory of the Lois de Police, a Functional Trend in Continental Private International Law - A Comparative Analysis with Modern American Theories' (1991) 39 American Journal of Comparative Law 661

Gutmann A, 'Democracy' in Goodin RE, Pettit P and Pogge T (eds), A Companion to Contemporary Political Philosophy vol 2 (Blackwell Publishing 2007)

Haar B, 'Civil Liability of Credit Rating Agencies - Regulatory All-or-Nothing Approaches between Immunity and Over-Deterrence' 2013-02 University of Olso Faculty of Law Legal Studies Research Paper Series 1

Hail L and Leuz C, 'International Differences in the Cost of Equity Capital: Do Legal Institutions and Securities Regulation Matter?' (2006) 44 Journal of Accounting Research 485

Halfmeier A, 'Recognition of a WCAM Settlement in Germany' [2012] 2012 Nederland International Privaatrecht 176

Hampton J, 'Democracy and the Rule of Law' in Shapiro I (ed), The Rule of Law: Nomos XXXVI (New York University Press 1994)

Hardin G, 'The Tragedy of the Commons' (1968) 162 Science 1243

Hart HLA, The Concept of Law (Oxford University Press 1994)

Hazard GC, Gedid JL and Sowle S, 'An Historical Analysis of the Binding Effect of Class Suits' (1998) 146 University of Pennsylvania Law Review 1849

HCCH, 'The Judgments Project' (Hague Conference on Private International Law) $<$ http://www.hcch.net/index en.php?act=text.display\&tid=149> accessed 8 July 2014

---, 'Status Table: Convention of 30 June 2005 on Choice of Court Agreements' (Hague Conference on Private International Law) $<$ http://www.hcch.net/index en.php?act=conventions.status\&cid=98. $>$ accessed 8 July 2014

---, Conclusions and Recommendations adopted by the Council (Council on General Affairs and Policy of the Conference 17-20 April, 2012)

Healy JJ, 'Consumer Protection Choice of Law: European lessons for the United States' (2009) 19 Duke Journal of Comparative \& International Law 535

Healy P and Palepu K, 'Information Asymmetry, Corporate Disclosure, and the Capital Markets: A Review of the Empirical Disclosure Literature' (2001) 21 Journal of Accounting and Economics 405

Healy PM and Palepu KG, 'The Fall of Enron' (2003) 17 Journal of Economic Perspectives 3

Heller MA, 'The Tragedy of the Anticommons: property in the transition from Marx to Markets’ (1988) 111 Harvard Law Review 621 
Hensler DR, Class Action Dilemmas: Pursuing Public Goals for Private Gains (RAND Institute for Civil Justice, 1999)

Hensler DR and Rowe TD, 'Beyond "It Just Ain't Worth It": Alternative Strategies for Damages Class Action Reform’ (2001) 64 Law and Contemporary Problems 137

Hermans R and Tjeenk JdBL, 'International Class Action Settlements in the Netherlands since Converium' in Dodds-Smith I and Brown A (eds), The International Comparative Guide to: Class \& Group Actions 2013 (5th edn, Global Legal Group Ltd. 2012)

Hill CA, 'Regulating the Rating Agencies' (2004) 82 Washington University Law Quarterly 43

Hillman RA, 'Debunking some Myths about Unconscionability: a New Framework for UCC Section 2-302’ (1981-1982) 67 Cornell Law Review 1

Hirschman A0, Exit, Voice, and Loyalty: Responses to Decline in Firms (Harvard University Press 1970)

Hodges C, The Reform of Class and Representative Actions in European Legal Systems (Hart Publishing 2008)

---, 'Objectives, mechanisms and policy choices in collective enforcement and redress' in Steele J and Boom WHv (eds), Mass Justice: challenges of representation and distribution (Edward Elgar 2011)

---, 'Public and Private Enforcement: the practical implications for policy architecture' in Brownsword R and others (eds), The Foundations of European Private Law (Hart Publishing 2011)

Hodges C, Vogenauer S and Tulibacka M (eds), The Costs and Funding of Civil Litigation: a Comparative Perspective (Hart Publishing 2010)

Huber P, Rome II regulation: Pocket Commentary (Sellier European Law Publ. 2011)

Humphrey C, Benau MAG and Barbadillo ER, 'El Debate de la Responsabilidad Civil de la Auditoría en España: la Construcción del Discurso sobre la Limitación de Responsabilidades por las Corporaciones Profesionales' (2003) XXXII Revista Española de Financiación y Contabilidad 1091

ICC ICoC, 'ICC Cost Calculator' <http://www.iccwbo.org/Products-andServices/Arbitration-and-ADR/Arbitration/Cost-and-payment/Cost-calculator/> accessed 8 July 2014

---, Enforcement of International Arbitral Awards: Report and Preliminary Draft Convention (ICC Brochure No 174, Paris, 1953)

III DEC, 'Comity as Conflict: Resituating International Comity as Conflict of Laws' (20102011) 44 UC Davis Law Review 11

ILA ICAC, 'Interim Report: "res judicata" and Arbitration' (Berlin Conference)

International T, Global Corruption Report 2007 (Cambridge University Press 2007) 
Investopedia, 'Depositary Receipt' <http://www.investopedia.com/terms/d/depositaryreceipt.asp > accessed 8 July 2014

Issacharoff S, 'Governance and Legitimacy in the Law of Class Actions' [1999] 1999 Supreme Court Review 337

Issacharoff S and Samuel I, 'New Frontiers of Consumer Protection: the Interplay Between Private and Public Enforcement' in Cafaggi F and Micklitz H-W (eds), New Frontiers of Consumer Protection: the Interplay Between Private and Public Enforcement (Intersentia 2009)

Jackson HE and Roe MJ, Public and Private Enforcement of Securities Laws: Resource-Based Evidence (Harvard Law School 2009)

Jarsulic M, Anatomy of a Financial Crisis: a Real Estate Bubble, Runaway Credit Markets, and Regulatory Failure (Palgrave Macmillan 2010)

Jensen MC and Meckling WH, 'Theory of the Firm: Managerial Behavior, Agency Costs and Ownership Structure' (1976) 3 Journal of Financial Economics 305

Jr FD and Jr HZ, Curso de Direito Processual Civil: Processo Coletivo, vol 4 (Editora Podivm 2011)

Jr. FT and Pollitt DH, 'Impeachment of Federal Judges: an Historical Overview' (19701971) 49 North Carolina Law Review 87

Jr. JCC, 'A Theory of Corporate Scandals: Why the United States and Europe Differ' in Norton JJ and Rickford J (eds), Corporate Governance Post-Enron: Comparative and International Aspects (British Institute of International and Comparative Law 2006)

Jr. WCP, Report of Investigation by the Special Investigative Committee of the Board of Directors of Enron Corp. (2002)

Junior FD, Curso de Direito Processual Civil - Volume 2 (5 edn, Editora JusPODIVM 2010)

Júnior HT, Curso de Direito Processual Civil - teoria geral do direito processual civil e processo de conhecimento, vol 1 (Forense 2012)

Kahan M, 'Securities Laws and the Social Costs of "Inaccurate" Stock Prices' (1992) 41 Duke Law Journal 977

Kaye JS and Lippman J, A Guide to Small Claims in the NYS City, Town and Village Courts (New York State Unified Court System New York State Unified Court System)

King RG and Levine R, 'Finance and Growth: Schumpeter Might be Right' (1993) 108 The Quarterly Journal of Economics 717

Kolb R (ed) Lessons from the Financial Crisis: Causes, Consequences, and our Economic Future (John Wiley \& Sons 2010)

Kolb RW, The Financial Crisis of Our Time (Oxford University Press 2011)

--- (ed) Financial Contagion: The Viral Threat to the Wealth of Nations (John Wiley \& Sons 2011) 
Kreher PJ and III PDR, 'Substance, Process, and the Future of Class Arbitration' (2004) 9 Harvard Negotiation Law Review 409

Kripke H, 'The SEC, the Accountants, Some Myths and Some Realities' (1970) 45 New York University Law Review 1151

Kritzer HM, Risks, reputations, and rewards : contingency fee legal practice in the United States (Stanford Law and Politics 2004)

Kroszner R, 'The Role of Private Regulation in Maintaining Global Financial Stability' (1999) 18 Cato Journal 355

Kruger T, Civil Jurisdiciton Rules of the EU and their Impact on Third States (Oxford University Press 2008)

Laby AB, 'Selling Advice and Creating Expectations: Why Brokers Should be Fiduciaries' (2012) 87 Washington Law Review 707

Lacovara PA, 'Class Action Arbitrations - the Challenge for the Business Community' (2008) 24 Arbitration International 541

LaCroix K, 'The Modest Early Settlements of Securities Suits Involving U.S.-Listed Chinese Companies' (The D\&O Diary, 22 June 22)

<http://www.dandodiary.com/2012/06/articles/securities-litigation/the-modest-

early-settlements-of-securities-suits-involving-u-s-listed-chinese-companies/> accessed 07 July 2014

Landes WM and Posner RA, 'The Private Enforcement of Law' (1975) 4 Journal of Legal Studies 1

Langevoort DC, 'Basic at Twenty: Rethinking Fraud on the Market' [2009] Wisconsin Law Review 151

LaPorta R, Lopez-de-Silanes F and Shleifer A, 'Corporate Ownership around the World' (1999) 54 The Journal of Finance 471

---, 'What Works in Securities Law?' (2006) 61 The Journal of Finance 1

LaPorta R and others, 'Investor Protection and Corporate Valuation' (2002) 57 The Journal of Finance 1147

LaPorta R and others, 'Legal Determinants of External Finance' (1997) 52 The Journal of Finance 1131

Larkins C, 'Judicial Independence and Democratization: a Theoretical and Conceptual Analaysis' (1996) 44 The American Journal of Comparative Law 605

Larosière Jd, The High-Level Group on Financial Supervision (2009)

Law J and Smullen J, A Dictionary of Finance and Banking (Oxford University Press 2008)

Layton A, 'Collective Redress: policy objectives and practical problems' in Fairgrieve D and Lein E (eds), Extraterritoriality and Collective Redress (Oxford University Press 2012) 
Leab D and others, The Economic Depression (ABC-CLIO 2010)

Lemos M, 'Aggregate Litigation Goes Public: Representative Suits by State Attorneys General' (2012) 126 Harvard Law Review 486

Lemos MH and Minzner M, 'For-Profit Public Enforcement' (2014) 127 Harvard Law Review 853

Levine R and Zervos S, 'Stock Markets, Banks and Economic Growth' (1998) 88 The American Economic Review 537

Lewis M, Flash Boys: a Wall Street revolt (W.W. Norton \& Company Inc. 2014)

Lith HV, The Dutch Collective Settlements Act and Private International Law (Erasmus School of Law 2010)

López JJM, 'Las Acciones de Clase en el Derecho Español’ (2001) 03/2001 InDret 1

LoPucki LM, 'The Future of Court System Transparency' in Doherty JW, Reville RT and Zakaras L (eds), Confidentiality, Transparency, and the US Civil Justice System (Oxford University Press 2012)

MacCormick N, Rhetoric and The Rule of Law: A Theory of Legal Reasoning (Oxford 2005)

Macey JR and Miller GP, 'The Plaintiffs' Attorney's Role in Class Action and Derivative Litigation: Economic Analysis and Recommendations for Reform' (1991) 58 University of Chicago Law Review 1

Mackenzie $\mathrm{R}$ and others, The Manual on International Courts and Tribunals (Oxford University Press 2010)

Magnus U and Peter M, Brussels I Regulation (2nd edn, Sellier 2012)

Mahoney PG, 'Precaution Costs and the Law of Fraud in Impersonal Markets' (1992) 78 Virginia Law Review 623

Manne HG, Insider Trading and the Stock Market (The Free Press 1966)

Martinez JC, 'Recognizing and Enforcing Foreign Nation Judgments: the United States and Europe compared and contrasted - a call for revised legislation in Florida' (1995) 4 Journal of Transnational Law \& Policy 49

McCormick R, Legal Risk in the Financial Markets (2nd edn, Oxford University Press Inc. 2010)

McLean B and Elkind P, The Smartest Guys in the Room: the Amazing Rise and Scandalous Fall of Enron (Penguin Books 2003)

Mendes GF and Branco PGG, Curso de Direito Constitucional (7th edn, Editora Saraiva 2012)

Mercados BFSd, Estatuto Social da BM\&FBOVESPA Supervisão de Mercados - BSM (2011)

Merchán JFM, 'La Constitución de 1812 y el Arbitraje' (2012) 14 Revista del Club Español del Arbitraje 33 
Michaels R, 'Some Fundamental Jurisdictional Conceptions as Applied in Judgment Conventions’ (2006) 123 Duke Law School Legal Studies Research Paper Series 1

---, 'Two Paradigms of Jurisdiction' (2006) 27 Michigan Journal of International Law 1003

---, 'Recognition and Enforcement of Foreign Judgments' Max Planck Encyclopedia of Public

International

Law

$<$ http://opil.ouplaw.com/view/10.1093/law:epil/9780199231690/law-

9780199231690-e1848?rskey=dHgRET\&result=1\&prd=EPIL> accessed 8 July 2014

Micklitz H-W, The many concepts of social justice in European private law (Edward Elgar 2011)

Micklitz H-W, Stuyck J and Terryn E, Cases, Materials and Text on Consumer Law (Hart Publishing 2010)

Miller G, 'Some Agency Problems in Settlements' (1987) 16 Journal of Legal Studies 189

---, 'Conflicts of Interest in Class Action Litigation: an inquiry into the appropriate standard' [2003] 2003 University of Chicago Legal Forum 581

---, 'Compensation and Deterrence in Consumer Class Actions in the US and Europe' in Cafaggi F and Micklitz H-W (eds), New Frontiers of Consumer Protection: the interplay between private and public enforcement (Intersentia 2009)

Moloney N, EC Securities Regulation (Oxford University Press 2008)

---, 'Financial Services and Markets' in Baldwin R, Cave M and Lodge M (eds), The Oxford Handbook of Regulation (Oxford University Press 2010)

--- , How to protect investors: lessons from the EC and the UK (Cambridge University Press 2010)

Molot J, 'Litigation Finance: a market solution to a procedural problem' (2010-2011) 99 Georgetown Law Journal 65

Moran M, 'The Mutually Constitutive Nature of Public and Private Law' in Robertson A and Wu TH (eds), The Goals of Private Law (Hart Publishing 2009)

Mulheron R, The Class Action in Common Legal Systems (Hart Publishing 2004)

Muñoz DR, The Law of Transnational Securitization (Oxford University Press 2010)

Nacimiento P, 'Article V(1)(a)' in Kronke H and others (eds), Recognition and Enforcement of Foreign Arbitral Awards: a Global Commentary on the New York Convention (Wolters Kluwer Law \& Business 2010)

Nagareda R, The Law of Class Actions and Other Aggregate Litigation (Foundation Press 2009)

Nagareda RA, 'Class Certification in the Age of Aggregate Proof' (2009) 84 New York University Law Review 97 
Nagy T, 'Credit Rating Agencies and the First Amendment: Applying Constitutional Journalistic Protections to Subprime Mortgage Litigation' (2009) 94 Minnesota Law Review 140

NASAA, 'Mandatory Binding Arbitration: Is it Fair and Voluntary?' 15 September 2009 <http://www.nasaa.org/807/mandatory-binding-arbitration-is-it-fair-and-voluntary/> accessed 8 July 2014

Neves DAA, Manual de Direito Processual Civil (Metodo 2011)

Nuss JR, 'Public Policy Invoked as a Ground for Contesting the Enforcement of an Arbitral Award, or for Seeking its Annulment' (2013) 7 Dispute Resolution International 119

Nussbaum A, "Treaties on Commercial Arbitration: a Test of International Private-Law Legislation' (1942) 56 Harvard Law Review 219

Olson M, The logic of collective action: public goods and the theory of groups (Harvard University Press 1971)

Ostrom E, Governing the Commons: the evolution of institutions for collective action (Cambridge University Press 1990)

Pace NM and Zakaras L, Where the Money Goes: Understanding Litigation Expenditures for Producing Electronic Discovery (Rand Institute for Civil Justice 2012)

Paradise J and others, 'Evaluating Oversight of Human Drugs and Medical Devices: a Case Study of the FDA and Implications for Nanobiotechnology' (2009) 37 Journal of Law, Medicine \& Ethics 598

Partnoy F, 'The Siskel and Ebert of Financial Markets?: Two Thumbs Down for the Credit Rating Agencies' (1999) 77 Washington University Law Quarterly 619

Paul JR, 'The Transformation of International Comity' (2008) 71 Law and Contemporary Problems 19

Paulsson J, 'Ethics, Elitism, Eligibility’ (1997) 14 Journal of International Arbitration 13

Philosophy SEo, 'The Free Rider Problem' (Stanford Encyclopedia of Philosophy, 21 May 2003) < http://plato.stanford.edu/entries/free-rider/> accessed 7 July 2014

Pierson C, The Modern State (Routledge 2011)

Pinho HDBd, 'A Tutela Coletiva no Brasil e a Sistemática dos Novos Direitos' Revista Diálogo Jurídico

Pistor K, 'A Legal Theory of Finance' (2013) Columbia Public Law Research Paper No 13348

Poorter ID, 'Auditor's Liability Towards Third Parties within the EU: A Comparative Study Between the United Kingdom, the Netherlands, Germany and Belgium' (2008) 3 Journal of International Commercial Law And Technology 68

Poser NS, 'Securities Regulation in Developing Countries: the Brazilian Experience' (1966) 52 Virginia Law Review 1283 
Poudret J-F and Besson S, Comparative Law of International Arbitration (Sweet \& Maxwell 2007)

Pritchard AC, 'The SEC at 70: time for retirement?' (2005) 80 Notre Dame Law Review 1073

Quinn BJM, 'The Failure of Private Ordering and the Financial Crisis of 2008' (2009) 5 NYU Journal of Law \& Business 549

Rajan RG, Fault Lines; How Hidden Fractures Still Threaten the World Economy (Princeton University Press 2010)

Rauchway E, The Great Depression \& the New Deal: a Very Short Introduction (Oxford University Press 2008)

Ravanides C, 'Arbitration Clauses in Public Company Charters: an Expansion of the ADR Elysian Fields or a Descent into Hades?' (2007) 18 The American Review of International Arbitration 371

Ravdin G, 'One Step Forward, Two Steps Back: Arguing for a Transatlantic Investor Protection Regime' (2012) 50 Columbia Journal of Transnational Law 490

Redfern A and Hunter M, Law and Practice of International Commercial Arbitration (Sweet \& Maxwell 2004)

Redish MH, 'Class Actions and the Democratic Difficulty: rethinking the intersection of private litigation and public goals' [2003] 2003 University of Chicago Legal Forum 71

Reisman WM and Richardson B, 'Tribunals and Courts: An Interpretation of the Architecture of International Commercial Arbitration' in Berg AJVD (ed), Arbitration - The Next Fifty Years (Kluwer Law International 2012)

Reiss D, 'Fannie Mae and Freddie Mac and the Future of Federal Housing Policy: a Study of Regulatory Privilege' (2010) 61 Alabama Law Review 907

Research C, Securities Class Action Filings - 2011 in Review (2011)

---, Securities Class Action Filings - 2013 in Review (2013)

Ribstein LE, 'Bubble Laws' (2003) 40 Houston Law Review 77

Ringe W-G and Hellgardt A, 'The International Dimension of Issuer Liability - Liability and Choice of Law from a Transatlantic Perspective' (2011) 31 Oxford Journal of Legal Studies 23

Robertson A, 'Introduction: Goals, Rights and Obligations' in Robertson A and Wu TH (eds), The Goals of Private Law (Hart Publishing 2009)

Rogers JS, 'Conflict of Laws for Transactions in Securities Held Through Intermediaries' (2006) 39 Cornell International Law Journal 285

Romano R, 'The Sarbanes-Oxley Act and the Making of Quack Corporate Governance' (2005) 114 Yale Law Journal 1521 
Roose K, 'Carlyle Drops Arbitration Clause from I.P.O. Plans' (NYT Dealbook, 3 February 2012) <http://dealbook.nytimes.com/2012/02/03/carlyle-drops-arbitration-clausefrom-i-p-o-plans/> accessed 8 July 2014

Rose AM, 'The Multienforcer Approach to Securities Fraud Deterrence: a Critical Analysis' (2010) 158 University of Pennsylvania Law Review 2173

Rosenn K, 'The Protection of Judicial Independence in Latin America' (1987) 19 The University of Miami Inter-American Law Review 1

Rott P, Evaluation of the Effectiveness and Efficiency of Collective Redress Mechanisms in the European Union - country report Germany (2008)

Rubenstein WB, 'On What a "Private Attorney General" Is - And Why it Matters' (2004) 57 Vanderbilt Law Review 2129

---, 'On What a "Private Attorney General" is - and Why it Matters' (2004) 57 Vanderbilt Law Review 2129

Ruhl G, 'Consumer Protection in Choice of Law' (2011) 44 Cornell International Law Journal 569

Santos AdlO and Gimenez ID-P, Derecho Procesal Civil: El Proceso de Declaracion (3 edn, Editorial Universitaria Ramon Areces 2004)

Savarese J and III GC, 'Uptade on the Halliburton Fraud-on-the-Market Case' (The Harvard Law School Forum on Corporate Governance and Financial Regulation, 15 January 2014) <https://blogs.law.harvard.edu/corpgov/2014/01/15/update-on-the-halliburtonfraud-on-the-market-case/> accessed 7 July 2014

Scarso A, 'The Liability of Credit Rating Agencies in a Comparative Perspective' (2013) 4 Journal of European Tort Law 163

Schramm D, Geisinger E and Pinsolle P, 'Article II' in Kronke H and others (eds), Recognition and Enforcement of Foreign Arbitral Awards: a Global Commentary on the New York Convention (Wolters Kluwer Law and Business 2010)

Schwab C, 'Open an Account' <http://international.schwab.com/public/international/nn/open an account?country= BR.> accessed 7 July 2014

Schwarcz SL, 'Enron and the Use and Abuse of Special Purpose Entities in Corporate Structures' (2001-2002) 70 University of Cincinnati Law Review 1309

Scott HS, International Finance: transactions, policy, and regulation (Foundation Press 2010)

Sebok A, ‘The Inauthentic Claim’ (2011) 64 Vanderbilt Law Review 61

SEC, 'The Investor's Advocate' (SEC) < http://www.sec.gov/about/whatwedo.shtml $>$ accessed 11 April 2012

Seligman J, 'The Historical Need for a Mandatory Corporate Disclosure System' (1983) 9 The Journal of Corporation Law 1 
---, The Transformation of Wall Street: A History of the Securities and Exchange Commission and Modern Corporate Finance (Northeastern University Press 1995)

Service F0, The Ombudsman and Larger Businesses (2012)

Services DIMa, Evaluation of FIN-NET (Final Report June, 2009)

Shavell S, "The Fundamental Divergence Between the Private and the Social Motive to Use the Legal System' (1997) 26 Journal of Legal Studies 575

Shell R, 'Arbitration and Corporate Governance' (1989) 67 North Carolina Law Review 517

Sheppard A, 'Res Judicata and Estoppel' in Cremades B and Lew J (eds), Parallel State and Arbitral Procedures in Interantional Arbitration (ICC 2005)

Shleifer A and Wolfenzon D, 'Investor Protection and Equity Markets' (2002) 66 Journal of Financial Economics 3

Silberman L, 'The Impact of Jurisdictional Rules and Recognition Practice on International Business Transactions: The U.S. Regime' (2004) 26 Houston Journal of International Law 327

---, 'Preclusion Doctrine' in Hershkoff OGCaH (ed), Civil Litigation in Comparative Context (Thomson West 2007)

Silver C, '"We're Scared to Death": Class Certification and Blackmail' (2003) 78 New York University Law Review 1357

---, 'Ethics and Innovation' (2011) 79 George Washington Law Review 754

Skinner Q, 'The State' in Goodin R and Pettit P (eds), Contemporary Political Philosophy: An Anthology (Blackwell Publishing 2006)

Soto Hd, The Mystery of Capital: Why Capitalism Triumphs in the West and Fails Everywhere Else (Bantam Press 2000)

Spence M, 'Signaling in Retrospect and the Informational Structure of Markets' (2002) 92 The American Economic Review 434

Steele J and Boon WHv, 'Mass Justice and its Challenges' in Steele J and Boon WHv (eds), Mass Justice: challenges of representation and distribution (2011)

Steinberg M and Kirby B, 'The Assault on Section 11 of the Securities Act: a Study in Judicial Activism' (2010) 63 Rutgers Law Review 1

Stigler GJ, 'Public Regulation of the Securities Markets' (1964) 37 The Journal of Business 117

Stoll HR, 'Market Microstructure' in Constantinides GM, Harris M and Stulz RM (eds), Handbook of the Economics of Finance, vol 1A (Elsevier 2003)

Stout LA, 'The Unimportance of Being Efficient: An Economic Analysis of Stock Market Pricing and Securities Regulation' (1988) 87 Michigan Law Review 613 
Stringer D, 'Choice of Law and Choice of Forum in Brazilian International Commercial Contracts: Party Autonomy, International Jurisdiction, and the Emerging Third Way' (2005-2006) 44 Columbia Journal of Transnational Law 959

Strong SI, 'Enforcing Class Arbitration in the International Sphere: Due Process and Public Policy Concerns' (2008) 30 University of Pennsylvania Journal of International Law 1

---, 'From Class to Collective: The De-Americanization of Class Arbitration' (2010) 26 Arbitration International 493

Stronge WB, The Sunshine Economy (University Press of Florida 2008)

Sylla R, 'A Historical Primer on the Business of Credit Rating Agencies' (The Role of Credit Reporting Systems in the International Economy)

Symeonides S, 'Party Autonomy in Rome I and II from a Comparative Perspective' in Boele-Woelki K and others (eds), Convergence and Divergence in Private International Law - Liber Amicorum (Eleven International Publishing 2010)

Symeonides SC, 'Choice of Law in Cross-Border Torts: why plaintiffs win and should' (2009) 61 Hastings Law Journal 337

---, Choice of Law in the American Courts in 2009: Twenty-Third Annual Survey (2010)

System BoGotFR, Report to the Congress on Risk Retention (2010)

Szalai IS, 'The Federal Arbitration Act and the Jurisdiction of the Federal Courts' (2007) 12 Harvard Negotiation Law Review 319

Talisse RB, 'Democracy' in Gaus G and D'Agostino F (eds), The Routledge Companion to Social and Political Philosophy (Routledge 2013)

Talley EL, 'Cataclysmic Liability Risk among Big Four Auditors' (2006) 106 Columbia Law Review 1641

Teubner G, Law as an Autopoietic System (Blackwell Publishers 1993)

Timmer LJ, 'Abolition of Exequatur under the Brussels I Regulation: Ill Conceived and Premature?' (2013) 9 Journal of Private International Law 129

Twitchell M, 'Why We Keep Doing Business with Doing-Business Jurisdiction' (2001) 2001 University of Chicago Legal Forum 171

Tzankova I, Netherlands National Report - part 2 (2008)

UNCITRAL, 'Status: Convention on the Recognition and Enforcement of Foreign Arbitral Awards (New York, 1958)' (UNCITRAL) $<$ http://www.uncitral.org/uncitral/en/uncitral texts/arbitration/NYConvention status.

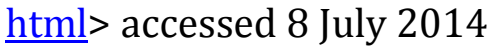

Vanberg G, 'Establishing and Maintaining Judicial Independence' in Whittington K, Kelemen D and Caldeira G (eds), The Oxford Handbook of Law and Politics (Oxford University Press 2008) 
Velden Jvd and Stefanelli J, The Effect in the European Community of Judgments in Civil and Commercial Matters: Recognition, Res Judicata and Abuse of Process (British Institute of International and Comparative Law 2008)

Viscasilas P, 'Arbitrability of (Intra-) Corporate Disputes' in Mistelis LA and Brekoulakis SL (eds), Arbitrability: International \& Comparative Perspectives (Wolters Kluwer 2009)

Weber M, The Theory of Social and Economic Organization (The Free Press 1947)

---, Economy and Society (University of California Press 1978)

---, From Max Weber: Essays in Sociology (Routledge 1991)

Wegen G and Lindemann C, 'The Law Applicable to Public Offerings in Continental Europe' in Houtte HV (ed), The Laws of Cross-Border Securities Transactions (Sweet \& Maxwell 1999)

Weintraub RJ, 'The Extraterritorial Application of Antitrust and Securities Law: an inquiry into the utility of a "choice-of-law" approach' (1992) 70 Texas Law Review 1799

Willging TE, Hooper LL and Niemic RJ, Empirical Study of Class Actions in Four Federal District Courts: Final Report to the Advisory Committee on Civil Rules (1996)

Wolff RP, In Defense of Anarchism (Harper \& Row 1998)

Wolff TB, ‘Preclusion in Class Action Litigation' (2005) 105 Columbia Law Review 717

Wurgler J, 'Financial Markets and the Allocation of Capital' (2000) 58 Journal of Financial Economics 187

Yeazell SC, 'Group Litigation and Social Context: Toward a History of the Class Action' (1977) 77 Columbia Law Review 866-96

---, 'The Past and Future of Defendant and Settlement Classes in Collective Litigation' (1997) 39 Arizona Law Review 687-704

Zeff SA, 'How the U.S. Accounting Profession got Where it is Today: Part I' (2003) 17 Accounting Horizons 189-205

---, 'How the U.S. Accounting Profession got Where it is Today: Part II' (2003) 17 Accounting Horizons 267-86

Zeynalova Y, 'The Law on Recognition and Enforcement of Foreign Judgments: is it broken and how do we fix it?' (2013) 31 Berkeley Journal of International Law

Zhang M, 'Party Autonomy and Beyond: an International Perspective of Contractual Choice of Law' (2006) 20 Emory International Law Review

Zingales L and others, Interim Report of the Committee on Capital Markets Regulation (30 November 2006) 